\title{
ENGINEERING ASSESSMENT \\ AND FEASIBILITY STUDY OF CHATTANOOGA SHALE AS A FUTURE SOURCE OF URANIUM
}

Mountain States Research and Development

Tucson, Arizona

PRC Toups Corporation

Orange, California

JUNE 1978

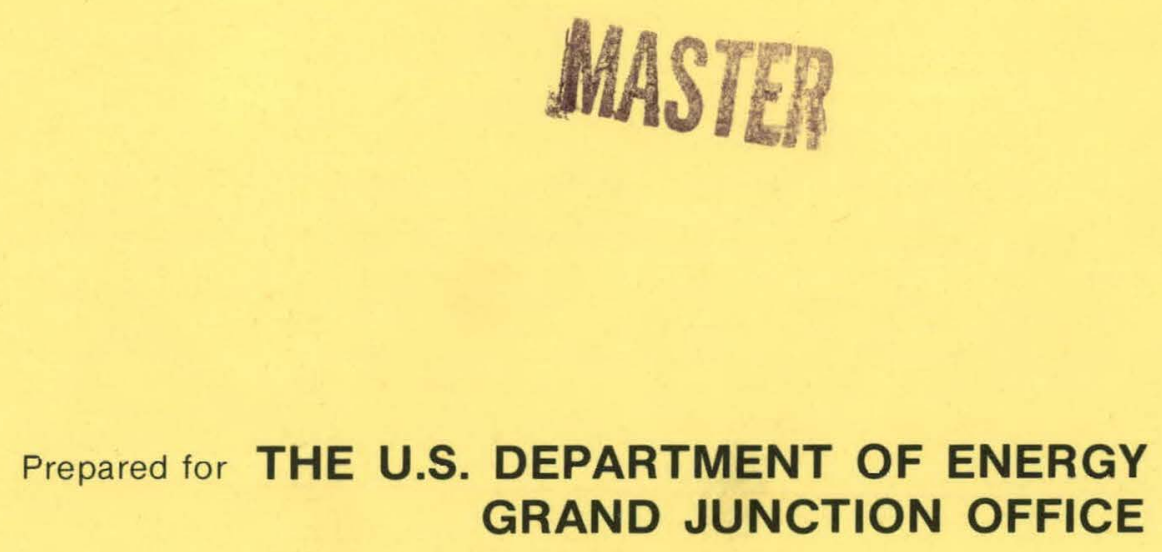




\section{DISCLAIMER}

This report was prepared as an account of work sponsored by an agency of the United States Government. Neither the United States Government nor any agency Thereof, nor any of their employees, makes any warranty, express or implied, or assumes any legal liability or responsibility for the accuracy, completeness, or usefulness of any information, apparatus, product, or process disclosed, or represents that its use would not infringe privately owned rights. Reference herein to any specific commercial product, process, or service by trade name, trademark, manufacturer, or otherwise does not necessarily constitute or imply its endorsement, recommendation, or favoring by the United States Government or any agency thereof. The views and opinions of authors expressed herein do not necessarily state or reflect those of the United States Government or any agency thereof. 


\section{DISCLAIMER}

Portions of this document may be illegible in electronic image products. Images are produced from the best available original document. 
This report was prepared as an account of work sponsored by the United States Government. Neither the United States nor the United States Department of Energy, nor any of their employees, nor any of their contractors, subcontractors, or their employees, makes any warranty, express or implied, or assumes any legal liability or responsibility for the accuracy, completeness, or usefulness of any information, apparatus, product, or process disclosed, or represents that its use would not infringe privately owned rights. 
ENGINEERING ASSESSMENT AND

FEASIBIIITY STUDY OF

CHATTANOOGA SHALE AS A

FUTURE SOURCE OF URANIUM

Prepared For

BENDIX FIELD ENGINEERING CORPORATION

GRAND JUNCTION OPERATIONS

Commissioned By

U.S. DEPARTMENT OF ENERGY

Prepared By

MOUNTAIN STATE3 REGEARCH AND DEVELOPMENT

P.O. BOX 17960

TUCSON, ARIZONA 85731

and

TOUPS CORPORATION

P.O. BOX 5367

972 TOWN \& COUNTRY ROAD

ORANGE, CALIFORNIA 92667 
VOLUME II

ASSESSMENT OF ENVIRONMENTAL, SOCIOECONOMIC, AND REGULATORY IMPACTS FROM CHATTANOOGA SHALE EXPLOITATION 
CONTENTS

VOLUNE I

$\underline{\text { Page }}$

ABSTRACT . . . . . . . . . . . . . . . . . . . . i

FOREWORD . . . . . . . . . . . . . . . . . . . . iv

ACKNOWLEDGMENTS . . . . . . . . . . . . . . . . . . XXiii

REPORT DEVELOPMENI PERSONNEL . . . . . . . . . . . . . . xxVi

I. INTRODUCTION AND SUMMARY . . . . . . . . . . . . . . I-1

SHALE STRATIGRAPHY .... . . . . . . . . . . . . . I-II

CRITICAL FEASIBILITY CONSIDERATIONS ........... I-11

Mineral Ownership . . . . . . . . . . . . . . . . I-13

Production Volume . . . . . . . . . . . . . . . . I-13

Mining Methods . . . . . . . . . . . . . . . . . . . I-13

Multiple Product Recovery ................. I-15

Waste Management . . . . . . . . . . . . . . I-16

Subsidence . . . . . . . . . . . . . . . . . . I-18

RECOMMNDATIONS FOR FURTHER STUDY . . . . . . . . . . . . I-19

II. GEOLOGY . . . . . . . . . . . . ...... II-I

GEOLOGICAL CHARACTER OF THE CHATTANOOGA SHALE

AND ADJACENT STRATA . . . . . . . . . . . . . . . . . . . II-I

Attitude . . . . . . . . . . . . . . . . . . . II-2

Stratigraphy ......... . . . . . . . . . . II-2

Mineral Content . . . . . . . . . . . . . . II-8

RESERVE AND RESOURCE ASSESSMENT . . . . . . . . . . II-12

Information from Holes vs. Information from Outcrops. . . II-14

Uranium Reserves and Resources in DeKalb County . . . . II-I7

Possible Uranium Reserves and Resources

in Other Tennessee Counties . . . . . . . . . . . . . . II-2I

Possible Uranium Resources in Adjoining States. . . . . . II-27

RECAPITULATION . . . . . . . . . . . . . . . II-28

III. MINING . . . . . . . . . . . . . . . . . III-I

PRODUCTION VOLUME . . . . . . . . . . . . . . . . III-1 
MINING SYSTEM PARAMETERS . . . . . . . . . . . . . . III-1

EQUIPMENT AND METHODS . . . . . . . . . . . . . . . III-2

SHALE TRANSPORTATION ................ . III-3

MINE VENTILATION . . . . . . . . . . . . . . . III-4

MINE DRAINAGE ...................... . . III-5

MAINTENANCE AND SERVICE . . . . . . . . . . . . . III-5

MINING COSTS . . . . . . . . . . . . . . . . . . III-6

IV. PROCESSING AND PRODUCTS . . . . . . . . . . . . . . IV-1

THE RANSTAD PROJECT . . . . . . . . . . . . . . . . IV-I

Project Status............ . . . . . . . . IV-2

Shale Characteristics .. . . . . . . . . . . IV-3

Processing . . . . . . . . . . . . . . . . . IV-19

Production Costs . . . . . . . . . . . . . . . . . . IV-20

Environmental Controls . . . . . . . . . . . . IV-39

CHATTANOOGA SHALE HYDRORETORTING . . . . . . . . . . . IV-44

Devonian Oil Shale Resources

of the Eastern United States . . . . . . . . . . . . . IV-45

Mining of Eastern Oil Shale .. . . . . . . . . . . IV-48

Environment and Land Reclamation . . . . . . . . . . . . . IV-51

Eastern Shale Hydroretorting Technology Status... . . IV-52

Economics of Eastern Shale Hydroretorting . . . . . . . IV-58

CHATTANOOGA SHALE RECOVERY PLANT ... . . . . . . . . . IV-61

General Process Description" . . . . . . . . . . . . IV-6I

Detailed Unit Process Description . . . . . . . . . . . IV-64

NET ENERGY YIELD FROM CHATTANOOGA SHALE . . . . . . . . . IV-67

Use of Thorium in Atomic Energy . . . . . . . . . . . . IV-72

V. ECONOMIC EVALUATION . . . . . . . . . . . . . . V-1

DEFINITIONS AND QUALIFICATIONS . . . . . . . . . . . . . V-1

BASIS AND METHODS FOR OPERATING COST ESTIMATE . . . . . . V-6

BASIS FOR CAPITAL COST ESTIMATES . . . . . . . . . . . V-7 
CONTENTS (Continued)

\begin{abstract}
Page
POTENTIAL ADDITIONAL PRODUCTS . . . . . . . . . . . V-8

DISCUSSION OF ECONOMIC EVALUATION . . . . . . . . V-65

VI. ANNOTATED BIBLIOGRAPHY . . . . . . . . . . . . . VI-1
\end{abstract}

\title{
VOLUME II
}

VII. INTRODUCTION . . . . . . . . . . . . . . . VII-1

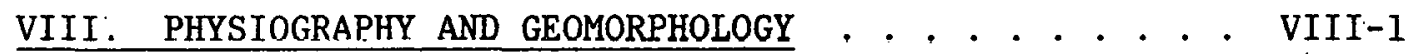

REGIONAL CHARACTERIZATION . . . . . . . . . . . . VIII-I

Soils . . . . . . . . . . . . . . . . . VIII-3

LOCAL CHARACTERIZATION . . . . . . . . . . . . . VIII-5

Geology . . . . . . . . . . . . . . . VIII-6

Soils....................... . VIII-10

IX. CLIMATOLOGY AND METEOROLOGY . . . . . . . . . . . IX-1

REGIONAL CHARACTERIZATION . . . . . . . . . . . . . . . . IX-1

Temperature . . . . . . . . . . . . . . . . . : IX-1

Precipitation :. . . . . . . . . . . . . . . IX-7

Winds . . . . . . . . . . . . . . . . IX IX-13

Storms . . . . . . . . . . . . . . . ... . IX-18

Atmospheric Stability and Inversions . . . . . . . . . IX-22

LOCAL CHARACTERIZATION . . . . . . . . . . . . , IX-29

Temperature ................... IX-29

Precipitation . . . . . . . . . . . . . . . . . . . . IX-31

Clouds and Visibility . . . . . . . . . . . . . IX-33

High Winds and Storms . . . . . . . . . . . . . . . IX-40

Atmospheric Stability . . . . . . . . . . . . . . IX-43

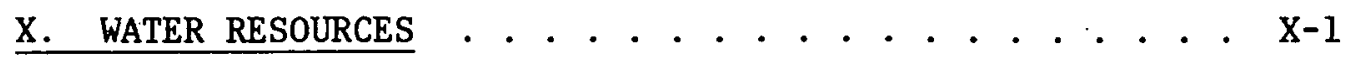

DESCRIPTION OF EXISTING CONDITIONS . . . . . . . . . . $\mathrm{X}-1$

Regional Characterization . . . . . . . . . . . $\mathrm{X}-1$

Local Characterization . . . . . . . . . . . . . X-13 
CONTENTS (Continued)

$\underline{\text { Page }}$

ANALYSIS OF IMPACTS . . . . . . . . . . . . . . . X-31

Ore Extraction.................... . X-31

Process Wastewater Streams .. . . . . ... . . . X X-32

Wastewater Management .. . . . . . . . . .. . . X-44

Eutrophication . . . . . . . . . . . . . . X-58

XI. BIOLOGICAL RESOURCES . . . . . . . . . . . , . XI-1

DESCRIPTION OF EXISTING CONDITIONS . . . . . . . . . . XI-1

Regional Characterization .............. XXI-1

Local Characterization . . . . . . . . . . . . XXI-5

ANALYSIS OF IMPACTS ................ XI-16

XII. AIR RESOURCES . . . . . . . . . . . . . . . . XII-1

DESCRIPTION OF. EXISTING CONDITIONS . . . . . . . . . . XII-1

Ambient Air Quality Standardd (AAQS). . . . . . . . . XII-1

Air Pollution Effects . . . . . . . . . . . . . . . . XII-2

Regional and Local Air Quality . ... . . . . . . . XII-6

Air Quality Trends.................. XII-13

ANALYSIS OF IMPACTS ................ XII-16

Air Pollutant Emission Estimation . . . . . . . . . XII-16

Ambient Alr Uuality Impact . . . . . . . . . . . . XII-26

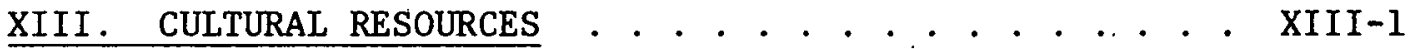

REGIONAL CHARACTERIZATION ................ XIII-1

Population . . . . . . . . . . . . . . . . XIII-3

LOCAL CHARACTERIZATION . . . . . . . . . . . . XIII-5

Land Use . . . . . . . . . . . . . . . . . . . . XIII-5

Social Profile . . . . . . . . . . . . . . . . XIII-7

Economic Profile................. . XIII-30

Public Facilities . . . . . . . . . . . . . XIII-53

ANALYSIS OF IMPACTS . . . . . . . . . . . . . XIII-58

Employment...................... XIII-60

Income . . . . . . . . . . . . . . . . . . XIII-70

Population . . . . . . . . . . . . . ... . XIII-73

Housing . . . . . . . . . . . . . . . . . . XIII-77 
CONTENTS (Continued)

Page

Land Use . . . . . . . . . . . . . . . . . . . XIII-79

Community Services and Public Facilities . . . . . . . XIII-86

Quality of Life .................. . XIII-94

XIV. REGULATORY CONSIDERATIONS . . . . . . . . . . . XIV-I

ENVIRONMENTAL IMPACT STATEMENTS . . . . . . . . . . XIV-2

NUCLEAR REGULATORY COMMISSION . . . . . . . . . . . XIV-5

WAIEK . . . . . . . . . . . . . . . . XIV-7

Federal Requirements .. . . . . . . . . . . . X XIV-7

State Requirements . . . . . . . . . . . . . . XIV-13

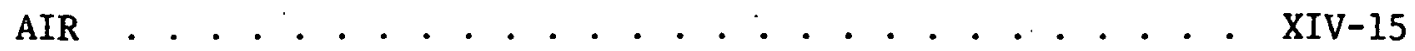

Federal Requirements ................. . XIV-15

State Requirements . . . . . . . . . . . . . . XIV-25

Future Air Pollution Regulation . . . . . . . . . . XIV-26

PROTECTED SPECIES . . . . . . . . . . . . . . . XIV-28

SOLID WASTES . . . . . . . . . . . . . . . . XIV-29

Federal Requirements .. . . . . . . . . . . . XIV-29

State Requirements ................. XIV-30

NOISE . . . . . . . . . . . . . . . . XIV-31

SURFACE MINING/RECLAMATION . . . . . . . . . . . . . XIV-31

Federal Requirements ................... XIV-31

State Requirements . . . . . . . . . . . . . . . XIV-32

WORKER SAFETY ..................... . XIV-33

COUNTY REQUIREMENTS . . . . . . . . . . . . . . . XIV-33

SUMMARY AND CONCLUSIONS . . . . . . . . . . . . XIV-34

Summary . . . . . . . . . . . . . . . . . XIV-35

XV. ANNOTATED BIBLIOGRAPHY . . . . . . . . . . . . XV-1 


\section{CONTENTS (Continued)}

Page

VOLUME III

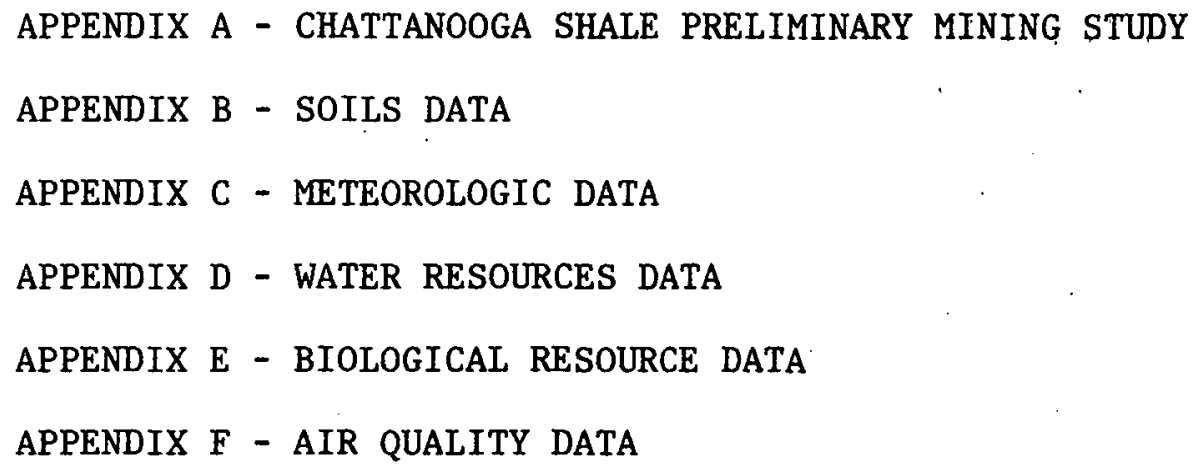




\section{LIST OF TABLES}

\begin{tabular}{|c|c|c|c|}
\hline No. & & & $\underline{\text { Page }}$ \\
\hline II -1 & $\begin{array}{l}\text { DISTRIBUT'ION OF ELEMENTS } \\
\text { GASSAWAY vS . OTHER SHALES . . . . . . . . }\end{array}$ & & II -10 \\
\hline II -2 & $\begin{array}{l}\text { COMPARISONS OF.CORE HOLES AND OUTCROPS } \\
\text { WITH RESPECT TO URANIUM GRADE DETERMINATIONS }\end{array}$ & . & II -16 \\
\hline II -3 & $\begin{array}{l}\text { INFLUENCE OF MAURY FORMATION UPON } \\
\text { URANIUM GRADE DETERMINATIONS IN DEKALB COUNTY }\end{array}$ & & II -22 \\
\hline II -4 & $\begin{array}{l}\text { URANIUM GRADES IN OUTCROPS AND DRILL HOLES } \\
\text { IN SEVERAL TENNESSEE COUNTIES } . \cdot . \cdot \cdot \cdot \cdot \cdot\end{array}$ & - & II -26 \\
\hline III -1 & COST SUMMARY FOR 3-MINE COMPLEX . & - & III -7 \\
\hline IV-1 & $\begin{array}{l}\text { COMPOSITION OF ALUMNIFEROUS SHALES AT RANSTAD, } \\
\text { SWEDEN, AND SWEDISH CONSUMPTION AND IMPORT OF } \\
\text { COMMODITIES CONTAINED IN THE SHALES } \cdot . \cdot \cdot\end{array}$ & , & IV -9 \\
\hline IV -2 & 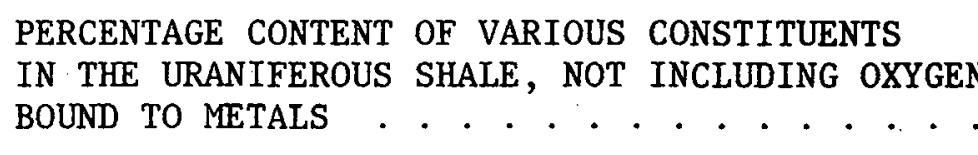 & N & IV -10 \\
\hline IV -3 & SHALE ANALYSIS . . . . . . . . . . . . . . & • & IV -11 \\
\hline IV -4 & PROJECTED SCALE OF OPERATIONS-REPORT OF 1974 & - & IV -21 \\
\hline IV -5 & BASIC SUPPLIES FOR PLANT OPERATION . $\cdot$. & - & IV -22 \\
\hline IV-6 & PROJECTED PRODUCTS FROM RANSTAD . . $\cdot$. & . & IV -23 \\
\hline IV-7 & $\begin{array}{l}\text { PROJECTED ENERGY DFMANT OF PLANT PROCESSING } \\
\text { ONE MILLION METRIC TONS OF SHALE PER YEAR }\end{array}$ & - & IV -24 \\
\hline IV -8 & CALCULATED WATER DEMAND DURING PLANT OPERATION & $\mathbf{N}$ & IV -25 \\
\hline IV-9 & $\begin{array}{l}\text { CALCULATED WATER QUALITY IN TWO PLANT AREAS } \\
\text { AND CORRESPONDING YEARLY DISCHARGES } . \cdot \cdot \text {. }\end{array}$ & - & IV -26 \\
\hline IV-10 & SOLID CONSTITUENTS OF LEACH RESIDUE & • & IV -40 \\
\hline IV-11 & COMPOSITION OF LEACH SOLUTIONS . . . $\cdot \cdot \cdot \cdot$ & - & IV -41 \\
\hline IV-12 & $\begin{array}{l}\text { ANALYSIS OF DRIED SALT PRODUCT FROM } \\
\text { LEACH LIQUOR-LABORATORY TEST } . . . . . . . .\end{array}$ & & IV -42 \\
\hline
\end{tabular}


LIST OF TABLES (Continued)

Page

IV-13 QUANTITIES OF SUBSTANCES RELEASED IN MOISTURE CONTENT OF LEACH RESIDUE .......... . . . IV-43

IV-14 RESULTS OF SHALE SAMPLING PROGRAM . . . . . . . IV-47

IV-15 ESTIMATED RESOURCES OF SHALE OIL RECOVERABLE BY ABOVEGROUND HYDRORETORTING IN THE APPALACHIAN, ILLINOIS, AND MICHIGAN BASIN AREAS . . . IV-49

IV-16 COST IN SELECTED STATES FOR MINING EASTERN OIL SHALE . . . . . . . . . . . IV-50

IV-17 COMPOSITION OF EASTERN AND WESTERN SHALES . . . IV-53

IV-18 BENCH-SCALE TEST RESULTS . . . . . . . . . IV-55

IV-19 PRELIMINARY INVESTMENT AND OPERATING COSTS FOR THE PRODUCTION OF SNG BY THE IGT HYDRORETORTING PROCESS ................ . IV-59

IV-20 PRELIMINARY INVESTMENT AND OPERATING COSTS FOR THE PRODUCTION OF SYNTHETIC OIL BY THE IGT HYDRORETORTING PROCESS ......... . IV-60

IV-2I PROCESS PLANT MATERIALS BALANCE . . . . . . . IV-63

IV-22 MINERALOGICAL AND CHEMICAL ANALYSIS OF PLANT FEED AND PRODUCTS . . . . . . . . . . IV-65

IV-23 GROSS ENERGY IN ONE TON OF BITUMINOUS COAL COMPARED TO ONE TON OF CHATTANOOGA SHALE (WITH URANIUM BURNED IN THE LWR WITH THROWAWAY CYCLE) . . . . . . . . . . . . . . IV-68

IV-24 NET ELECTRICAL ENERGY IN ONE TON OF BITUMINOUS COAL COMPARED IIO NET ENERGY FROM FISSIONING RECOVERABLE URANIUM IN ONE TON OF CHATTANOOGA SHALE (WITH URANIUM BURNED IN THE LWR WITH THROWAWAY CYCLE) . . . . . . . . . . . . IV-69.

IV-25 NET ELECTRICAL ENERGY IN ONE TON OF BITUMINOUS COAL COMPARED TO NET URANIUM ENERGY PLUS OTHER SOURCES OF REALIZABLE ENERGY IN ONE TON OF CHATTANOOGA SHALE (IN THE LWR WITH RECYCLE OF PLUTONIUM) . . . . . . . . . . . . . . IV-70

IV-26 NET ELECTRICAL ENERGY IN ONE TON OF BITUMINOUS COAL COMPARED TO NET TOTAL ENERGY REALIZABLE THROUGH BREEDER REACTOR CYCLE PLUS THERMAL SOURCES IN ONE TON OF CHATTANOOGA SHALE . . . . IV-71 
$\underline{\text { Page }}$

V-1 ECONOMIC EVALUATION CASES ..........

V-2 RECENT PRODUCTION OF U, V, Co, Ni, Mo, Th . . V-10

IX-1 WIND DATA SOURCES IN THE REGIONAL STUDY AREA . . IX-16

IX-2 MONTHLY AND ANNUAL THUNDERSTORM FREQUENCY

IN THE REGIONAL STUDY AREA . . . . . . . . . IX-20

IX-3 REGIONAL MIXING DEPTHS OVER THE STUDY AREA . . . IX-25

IX-4 REGIONAL STUDY AREA VENTILATION INDEX BREAKDOWN FOR 2- AND 5-DAY RESTRICTED VENTILATION EPISODES . . . . . . . . . . . . . . . . . . . IX-27

IX-5 CEILING HEIGHT FREQUENCY AT THE SMITHVILLE AIRPORT . . . . . . . . . . . . . . . . . IX-36

IX-6 PREDICTED MAXIMUM DEKALB COUNTY WINDS VERSUS RECURRENCE INTERVAL . . . . . . . . . . . . . IX-42

IX-7 NUCLEAR REGULATORY COMMISSION GUIDELINES ON STABILITY CLASS STRATIFICATION USING TEMPERATURE DIFFERENCE ( T) MEASUREMENTS . . . . . . . . . . IX-45

IX-8 TURBULENCE CLASSIFICATION SCHEME USED IN THE STAR COMPUTER PROCESSING ROUTINE . . . . . . . IX-46

X-1 AVERAGE AND LOW FLOW STREAMFLOW - CENTER HILL LAKE REGION ... . . . . . . . . . . . X-15

X-2 SURFACE WATER QUALITY - CENTER HILL LAKE REGION . . . . . . . . . . . . . . . . $\mathrm{X}-25$

X-3 CHEMICAL QUALITY OF SELECTED WELLS AND SPRINGS - $\mathrm{X}-30$ X-4 COMPOSITION OF EASTERN AND WESTERN SHALES . . X X-35

X-5 ALKANOIC ACIDS IN ORGANIC FRACTION RETORT WATER .. . . . . . . . . . . . . . $\mathrm{X}-36$

X-6 COMPONENTS OF THREE OIL SHALE WASTE WATERS . . . X-37

X-7 SUMMARY OF CHEMICAL ANALYSES PERFORMED BY VARIOUS ANALYSTS ON RETORT WATER FROM LARAMIE ENERGY RESEARCH CENTER 150-TON AND 10-TON RETORTS . . . . . . . . . . . . . . . . . . $\mathrm{X}-38$

X-8 COMPOSITION OF LIME-TREATED LEACH RESIDUE MOISTURE AT RANSTAD . . . . . . . . . . . . . X-43 
LIST OF TABLES (Continued)

$\underline{\text { Page }}$

X-9 WATER QUALITY OF LEACHATE FROM SPENT UTAH SHALE . . . . . . . . . . . . . . . . . . . $\mathrm{X}-45$

X-10 ELEMENTAL COMPOSITION OF THE CHATTANOOGA SHALE . X-46

X-11 RELATIVE MOBILITIES OF THE ELEMENTS IN THE SUPERGENE ENVIRONMENT . . . . . . . . . . . . . X-47

XII-1 AMBIENT AIR QUALITY STANDARDS FOR THE REGIONAL

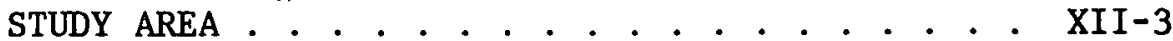

XII-2 GASEOUS POLLUTANT EMISSIONS FROM HEAVY-DUTY DIESEL-POWERED EQUIPMENT IN THE SHALE MINES . . XII-20

XII-3 TOTAL POLLUTANT EMISSIONS FROM 100,000 TON/DAY SHALE MINING PROCEDURES . . . . . . . . . . XII-22

XII-4 APPROXIMATE VEHICULAR EMISSIONS FROM PROJECTSTIMULATED GROWTH IN DEKALB COUNTY . . . . . . . XII-25

XII-5 AVERAGE ANNUAL DISPERSION FACTORS . . . . . . XII-28

XIII-1 EXISTING AND PROJECTED LAND USES IN DEKALB COUNTY . . . . . . . . . . . . . . . . XIII-8

XIII-2 TRENDS IN DEKALB COUNTY POPULATION SIZE . . . XIII-10

XIII-3 NET MIGRATION FOR DEKALB COUNTY . . . . . . . XIII-11

XIII-4 CHILDREN/WOMEN RATIO IN DEKALB COUNTY . . . . XIII-13

XIII-5 PERCENTAGE CHANGES IN AGE GROUPS STRUCTURE . . XIII-15

XIII-6 SUMMARY OF DEKALB COUNTY POPULATION CHARACTERISTICS ........... XIII-16

XIII-7 COMPONENTS OF POPULATION CHANGE, ACTUAL AND PROJECTED, IN DEKALB COUNTY AND INCORPORATED TOWNS . . . . . . . . . . . . . . . . . . . . . XIII-18

XIII-8 POPULATION TRENDS AND PROJECTIONS FOR DEKALB COUNTY AND SMITHVILLE ........... XIII-20

XIII-9 TOTAL HOUSING UNITS BY TYPE OF STRUCTURE . . . . XIII-22

XIII-10 PERCENT OF TOTAL PRIVATE HOUSING UNITS IN DEKALB COUNTY BY TYPE OF STRUCTURE . . . . . . . XIII-23 
LIST OF TABLES (Continued)

$\underline{\text { Page }}$

XIII-11 ESTIMATED OCCUPIED HOUSING UNITS BY CONDITION • XIII-25

XIII-12 UNMET HOUSING NEEDS IN DEKALB COUNTY . . . . . . XIII-26

XIII-13 FUTURE AND CUMULATIVE HOUSING NEEDS . . . . . . XIII-27

XIII-14 TRENDS IN ELDERLY (OVER 62 YEARS) COMPONENT OF

POPULATION . . . . . . . . . . . . . . . . . . XIII-29

XIII-15 PER CAPITA PERSONAL INCOME TRENDS . . . . . . XIII-32

XIII-16 PERCENTAGE INCREASE IN PER CAPITA PERSONAL

INCOME . . . . . . . . . . . . . . . . . . . . . XIII-34

XIII-17 MEDIAN FAMILY INCOME. . . . . . . . . . . . XIII-35

XIII-18 EFFECTIVE BUYING INCOME ........... . XIII-36

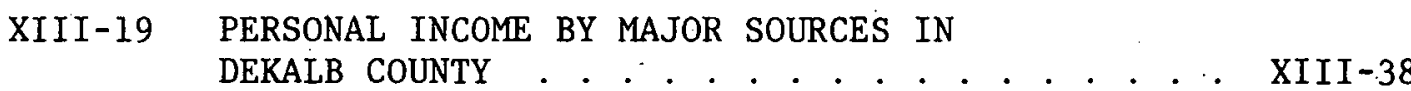

XIII-20 EMPLOYMENT BY MAJOR GROUP . . . . . . . . . . XIII-4I

XIII-21 EMPLOYMENT BY MAJOR GROUP AS A PERCENTAGE OF

TOTAL EMPLOYMENT . . . . . . . . . . . . . XIII -42

$\begin{array}{ll}\text { XIII-22 } & \text { BREAKDOWN OF AGRICULTURAL EARNINGS IN } \\ & \text { DEKALB COUNTY . . . . . . . . . . . . . . . . . XIII-43 }\end{array}$

XIII-23 DEKALB COUNTY AGRICULTURAL PRODUCTION . . . . . XIII-45

XIII-24 CHANGE IN DEKALB COUNTY EARNINGS BY BROAD

INDUSTRIAL SECTOR . . . . . . . . . . . . . . . XIII-46

XIII-25 PUBLIC VISITATIONS TO CENTER IIILL LAKE . . . . XIII-48

XIII-26 LABOR FORCE ESTIMATES FOR DEKALB COUNTY . . . XIII-5I

XIII-27 ANNUAL AVFRAGE UNEMPLOYMENT RATE . . . . . . . XIII-52

XIII-28 LOCAL PUBLIC USE RECREATION FACILITIES OF

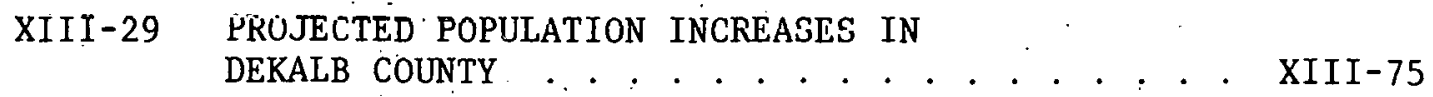

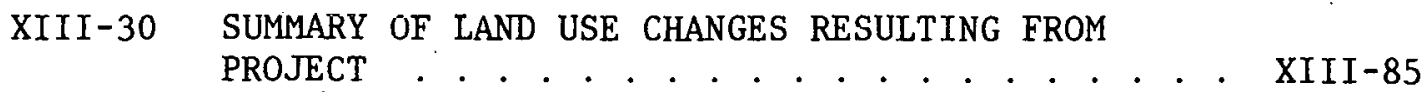




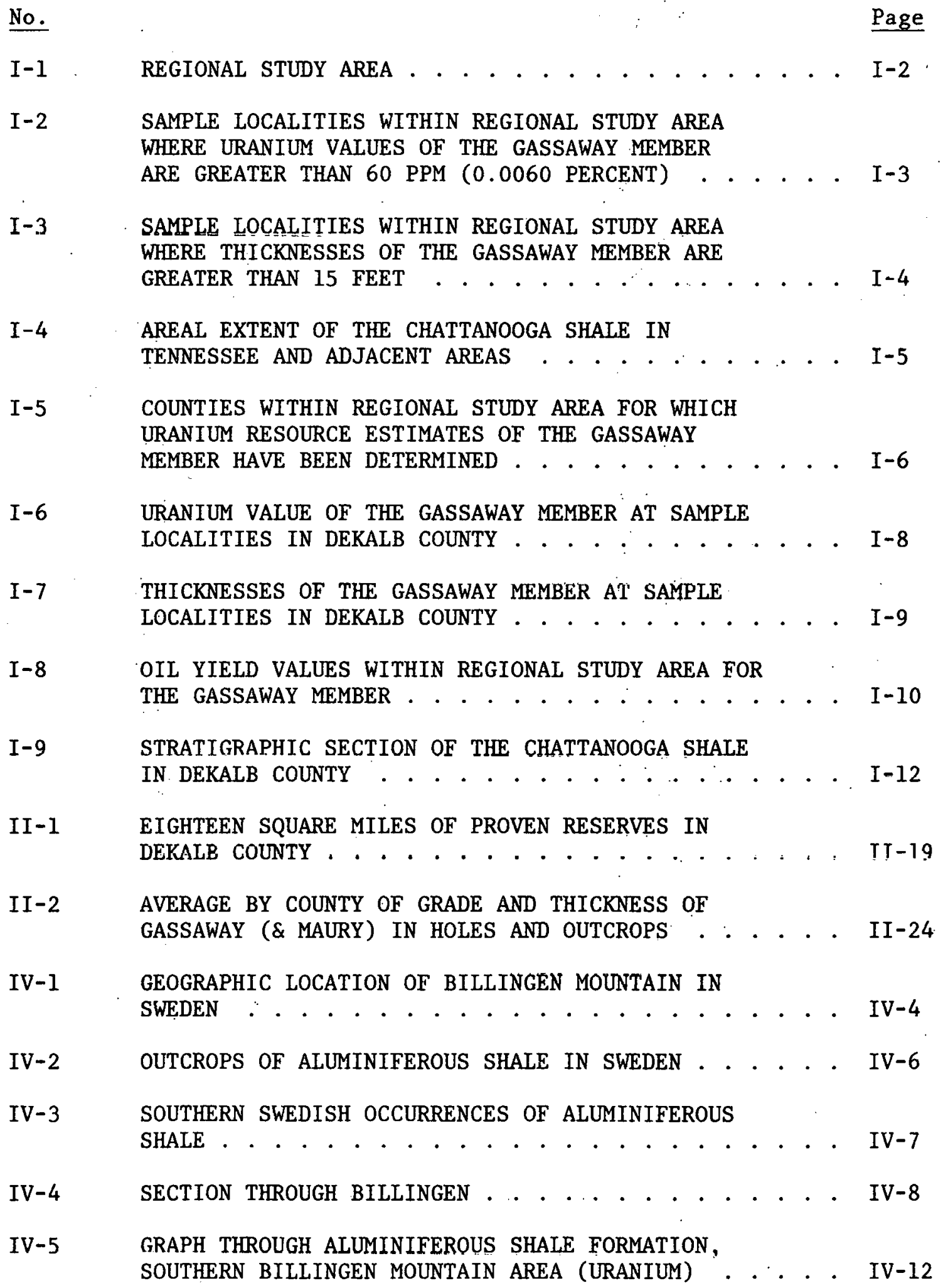


LIST OF FIGURES (Continued)

No.

$\underline{\text { Page }}$

IV-6 GRAPH THROUGH ALUMINIFEROUS SHALE FORMATION, SOUTH BILLINGEN MOUNTAIN AREA (ORGANIC CARBON) . IV-13

IV-7 ASSAY OF URANIUM VS KEROGEN IN ORGANIC CARBON ZONE OF UPPER SHALE . . . . . . . . . . . . . . IV-14

IV-8 GRAPH THROUGH ALUMINIFEROUS SHALE FORMATION, SOUTH BILLINGEN MOUNTAIN AREA (VANADIUM) . . . . IV-15

IV-9 GRAPH THROUGH ALUMINIFEROUS SHALE FORMATION, SOUTH BILLINGEN MOUNTAIN AREA (SULFUR) . . . . IV-16

IV-10 GRAPH THROUGH ALUMINIFEROUS SHALE FORMATION, SOUTH BILLINGEN MOUNTAIN AREA (MOLYBDENUM) . . . IV-17

IV-11 SECTION THROUGH ALUMINIFEROUS SHALE FORMATION (POTASSIUM AND ALUMINUM) . . . . . . . . . . IV-18

IV-12 FLOW SHEET - REPORT OF 1974 . . . . . . . . . IV-27

IV-13 GENERAL PICTORIAL FLOWSHEET ORIGINAL RANSTAD URANIUM PLANT . . . . . . . . . . IV-28

IV-14 BLOCK DIAGRAM - UNIT OPERATIONS CURRENT PLANT • IV-29 IV-15 HEAVY MEDIA SEPARATION PLANT - DETAIL . . . . IV-30 IV-16 URANIUM RECOVERY FLOW SHEET - DETAIL . . . . . . IV-3I

IV-17 MOLYBDENUM AND SODIUM SULFATE RECOVERY FLOW SHEET - DETAIL . . . . . . . . . . . . . IV-32

IV-18 FLOW SHEET FOR RECOVERY OF CHEMICAL FERTILIZER - DETAIL . . . . . . . . . . . IV-33

IV-19 FLOW SHEET FOR SULFURIC ACID PRODUCTION DETAIL . . . . . . . . . . . . . . IV-34

IV-20 FLOWSHEET FOR LIMESTONE PREPARATION - DETAIL . . IV-35

IV-21 EXTRACTION OF URANIUM AS A FUNCTION OF LEACHING TIME AT VARIOUS TEMPERATURES (DATA FROM PILOT TESTING) . . . . . . . . IV-36

IV-22 IRON AND ALUMINUM EXTRACTIONS AS FUNCTIONS OF ACID CONCENTRATION AND LEACHING TEMPERATURE (APPROXIMATELY $30 \%$ SOLIDS, 48 HOUR LEACH) . . . IV-37 
LIST OF FIGURES (Continued)

\begin{tabular}{|c|c|c|c|c|}
\hline No. & & & & Page \\
\hline IV -23 & $\cdot \cdot \cdot \cdot \cdot \cdot \cdot \cdot \cdot \cdot \cdot \cdot \cdot$ & . & • & IV -38 \\
\hline IV-24 & $\begin{array}{l}\text { PRINCIPAL REPORTED OIL-SHALE DEPOSITS OF } \\
\text { THE CONTERMINOUS UNITED STATES . . . . }\end{array}$ & . & • & $I V-46$ \\
\hline IV -25 & $\begin{array}{l}\text { ORGANIC CARBON RECOVERY WITH EASTERN SHALE } \\
\text { IN HYDROGEN } \\
\end{array}$ & • & - $\cdot$ & IV -54 \\
\hline IV -26 & SYNTHETIC OIL PRODUCTION FROM EASTERN SHALE & 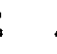 & . & IV -56 \\
\hline IV -27 & SNG YKÜÜUCTION FROH EASTERN IILALE & . & • & IV $=57$ \\
\hline IV-28 & CHATTANOOGA SHALE PROCESSING PLANT . & - & • & IV-62 \\
\hline$V-1$ & CASE 1 - ALL PRODUCTS & . & . & $V-66$ \\
\hline $\mathrm{V}-2$ & $\begin{array}{l}\text { CASE } 2 \text { - URANIUM, SYNCRUDE, } \mathrm{S}, \mathrm{NH}_{3} \text {, POWER, } \\
\text { NO METAL BY-PRODUCTS . . . . . . . . . . . }\end{array}$ & & . & $V-68$ \\
\hline $\mathbf{V}-3$ & 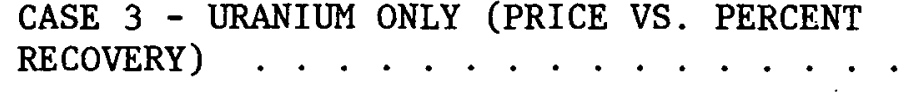 & . & . & $V-69$ \\
\hline V-4 & CASE 4 - URANIUM ONLY (PRICE VS. GRADE) & . & . & $V-70$ \\
\hline VII -1 & PROTOTYPE PROJECT LOCATION IN DEKALB COUNTY & 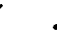 & • & VII-2 \\
\hline VIII-1 & $\begin{array}{l}\text { CHIEF PHYSIOGRAPHIC FEATURES OF REGIONAL } \\
\text { STUDY AREA . } . . . \\
\end{array}$ & & . & VIII-2 \\
\hline VIII-2 & SOILS OF THE REGIONAL STUDY AREA . & . & . & VIII-4 \\
\hline VIII-3 & $\begin{array}{l}\text { MAJOR PHYSIOGRAPHIC SEGREGATIONS OF DEKALB } \\
\text { COUNTY } . \cdot \cdot \cdot \cdot \cdot \cdot \cdot \cdot \cdot \cdot \cdot \cdot \cdot \cdot \cdot \cdot \cdot \cdot \cdot \cdot \cdot \cdot \cdot \cdot\end{array}$ & . & - $\cdot$ & VIII-7 \\
\hline VIII-4 & GENERAL SOIL MAP OF DEKALB COUNTY & - & • & VIII-11 \\
\hline IX-1 & 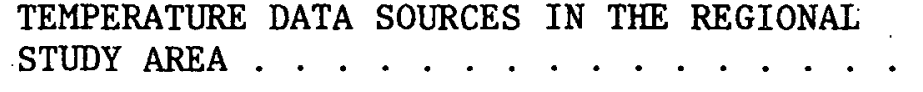 & & . & IX -3 \\
\hline IX -2 & 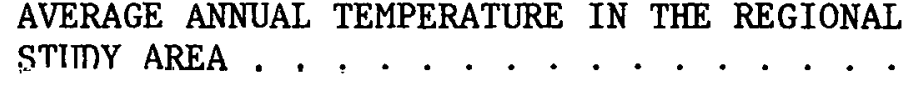 & & . & IX -4 \\
\hline IX -3 & 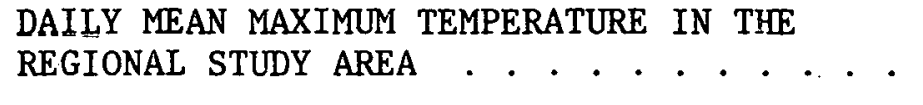 & & . & $1 \mathrm{X}-5$ \\
\hline IX-4 & $\begin{array}{l}\text { DAILY MEAN MINIMUM TEMPERATURE IN THE } \\
\text { REGIONAL STUDY AREA } \\
\end{array}$ & & . & IX -6 \\
\hline$x-5$ & NASHVILLE ANNUAL TEMPERATURE DISTRIBUTTYON & . & & IX-8 \\
\hline
\end{tabular}


No.

IX-6 CHATTANOOGA ANNUAL TEMPERATURE DISTRIBUTION . . IX-9

IX-7 PRECIPITATION DATA SOURCES IN THE REGIONAL STUDY AREA . . . . . . . . . . . . . IX-11

IX-8 AVERAGE ANNUAL PRECIPITATION IN THE REGIONAL STUDY AREA . . . . . . . . . . . . . . IX-12

IX-9 MONTHLY PRECIPITATION FREQUENCY DISTRIBUTION IN THE REGIONAL STUDY AREA . . . . IX IX-14

IX-10 MEAN ANNUAL SNOWFALL IN THE REGIONAL STUDY AREA . . . . . . . . . . . . . . IX-15

IX-11 TORNADO FREQUENCY PER UNIT AREA IN THE MIDWESTERN AND SOUTHEASTERN UNITED STATES . . . IX-23

IX-12 TOTAL NUMBER OF FORECAST DAYS OF HIGH METEOROLOGICAL POTENTIAL FOR HIGH AIR POLLUTION IN A 5-YEAR PERIOD THROUGHOUT THE UNITED STATES . . . . . . . . . . . . . IX-28

IX-13 ANNUAL TEMPERATURE DISTRIBUTION IN DEKALB COUNTY (SMITHVILLE AIRPORT) . . . . . . . . . IX-30

IX-14 MONTHLY PRECIPITATION FREQUENCY DISTRIBUTION IN DEKALB COUNTY . . . . . . . . . . . IX-32

IX-15 FREQUENCY OF OCCURRENCE OF RESTRICTED VISIBILITY IN DEKALB COUNTY (SMITHVILLE AIRPORT) . . . . . . . . . . . . . IX-34

IX-16 FOG FREQUENCY IN DEKALB COUNTY (SMITHVILLE AIRPORT) . . . . . . . . . . . IX-35

IX-17 DEKALB COUNTY WIND ROSE DERIVED FROM FIVE YEARS OF OBSERVATTONS . . . . . . . . . . . . . . . . . IX-38

IX-18 REGIONAL PREDICTED SUSTAINED MAXIMUM WINDS COMPARED TO SHORT-PERIOD DEKALB COUNTY OBSERVATIONS . . . . . . . . . . . . . . . IX-4I

IX-19 DISTRIBUTION OF PASQUILL-GIFFORD STABILITY CLASSES FOR DEKALB COUNTY DERIVED FROM NOAA STAR PROGRAM ............. . . . IX-49

IX-20 COMPARISON OF THE STAR AND T STABILITY CLASS DETERMINATIONS FOR CENTRAL AND EAST-CENTRAL TENNESSEE . . . . . . . . . . . . . . . IX IX-50 
LIST OF FIGURES (Continued)

\begin{tabular}{|c|c|c|c|}
\hline No. & & & Page \\
\hline$x-1$ & STREAMFLOW IN DEKALB COUNTY $\cdot \cdot \cdot \cdot \cdot \cdot \cdot$ & - . & $x-14$ \\
\hline$x-2$ & SPRING FLOWS IN DEKALB COUNTY & - $\cdot$ & $x-17$ \\
\hline $\mathrm{X}-3$ & ISO-SOIL MAP OF DEKALB COUNTY $\cdot \cdot \cdot \cdot \cdot \cdot$ & - $\cdot$ & $x-19$ \\
\hline$x-4$ & WATER WELL YIELDS IN DEKALB COUNTY • • • • & . $\cdot \cdot$ & $x-21$ \\
\hline $\mathrm{X}-5$ & CENTRAL WATER SERVICE IN DEKALB COUNTY • • & . $\cdot$ • & $x-24$ \\
\hline$x-6$ & SOURCES OF MAJOR PROCESS WASTE STREAMS • & - $\cdot \cdot$ & $x-34$ \\
\hline $\mathrm{X}-7$ & $\begin{array}{l}\text { ZERO DISCHARGE TREATMENT SCHEME FOR ALL } \\
\text { PROCESS WASTE STREAMS } \\
.\end{array}$ & - $\cdot$ & $x-49$ \\
\hline $\mathrm{X}-8$ & $\begin{array}{l}\text { SCHEMATIC DIAGRAM OF TAILINGS POND DURING } \\
\text { ACTIVE OPERATIONS } \\
\end{array}$ & . . & $x-52$ \\
\hline$x-9$ & 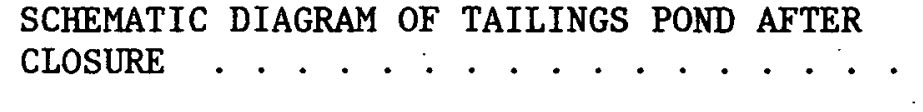 & - $\cdot \cdot$ & $x-53$ \\
\hline$x-10$ & $\begin{array}{l}\text { UTILIZATION OF NATURAL FEATURES TO ISOLATE } \\
\text { TAILINGS } \cdot \cdot \cdot \cdot \cdot \cdot \cdot \cdot \cdot \cdot \cdot \cdot \cdot \cdot \cdot \cdot \cdot \cdot \cdot \cdot \cdot \cdot \cdot\end{array}$ & $\cdot$ & $x-54$ \\
\hline$x-11$ & SEEPAGE FROM HYDRAULICALLY BACKFILLED MINES & . $\cdot$ & $x-56$ \\
\hline$x-12$ & $\begin{array}{l}\text { GEOLOGICAL CROSS SECTION ILLUSTRATING POTEN } \\
\text { PATH FOR SURFACE WATER CONTAMINATION . } \cdot \text {. }\end{array}$ & $\begin{array}{l}\text { NTIAL } \\
\cdot \cdot \cdot \text {. }\end{array}$ & $x-57$ \\
\hline $\mathrm{XI}-1$ & $\begin{array}{l}\text { POTENTIAL NATURAL VEGETATION WITHIN THE REG } \\
\text { STUDY AREA } \cdot \cdot \cdot \cdot \cdot \cdot \cdot \cdot \cdot \cdot \cdot \cdot \cdot \cdot \cdot \cdot \cdot \cdot \cdot \cdot \cdot \cdot \cdot \cdot \cdot \cdot \cdot\end{array}$ & 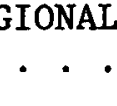 & $\mathrm{XI}-2$ \\
\hline $\mathrm{XI}-2$ & VEGETATION OF DEKALB COUNTY & - $\cdot$ & $\mathrm{XI}-7$ \\
\hline $\mathrm{XII}-1$ & 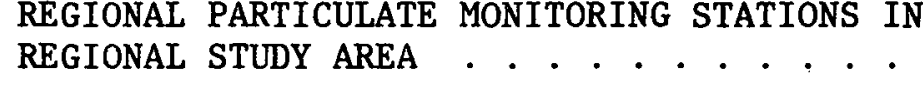 & $\begin{array}{l}\text { T THE } \\
\cdot \cdot \cdot\end{array}$ & XII-9 \\
\hline XII-2 & $\begin{array}{l}\text { ANNUAL (1976) GEOMETRIC MEAN TSP LEVELS IN } \\
\text { REGIONAL STUDY AREA } \\
\end{array}$ & $\begin{array}{l}\text { THE } \\
\cdot \cdot \cdot\end{array}$ & $\mathrm{XII}-10$ \\
\hline XII -3 & $\begin{array}{l}\text { 24-HOUR ANNUAL (1975) MAXIMUM TSP LEVELS IN } \\
\text { AROUND THE REGIONAL STUDY AREA . . . . . . }\end{array}$ & $\begin{array}{c}\text { AND } \\
\cdot \cdot \cdot\end{array}$ & XII-11 \\
\hline XII -4 & $\begin{array}{l}\text { 24-HOUR ANNUAL (1976) MAXIMUM TSP LEVELS IN } \\
\text { AROUND THE REGIONAL STUDY AREA } \cdot \cdot \cdot \cdot \cdot \cdot\end{array}$ & $\begin{array}{l}\text { S AND } \\
. \cdot .\end{array}$ & $\mathrm{XII}-12$ \\
\hline $\mathbf{\Delta 1 1}$ & $\begin{array}{l}\text { TENNESSEE TRENDS IN TSP STANDARD VIOLATIONS } \\
\text { INDICATING PROGRESS TOWARD ZERO EXCEEDANCES }\end{array}$ & & XII -15 \\
\hline
\end{tabular}




\section{LIST OF FIGURES (Continued)}

No.

$\underline{\text { Page }}$

XII-6 DISPERSION PATTERN FOR ONE TON PER DAY OF PARTICULATES EMITTED FROM CHATTANOOGA SHALE MINE AND PROCESSING OPERATIONS . . . . . . . . . XII-29

XII-7 ANNUAL AVERAGE IMPACT OF SO FROM CHATTANOOGA SHALE OIL RECOVERY OPERATIONS . . . . . . . . XII-3I

XII-8 ROADWAY EMISSIONS IMPACT UNDER HYPOTHESIZED WORST-CASE CONDITIONS . . . . . . . . . . XII-33

XIII-1 GENERALIZED LAND USE PATTERN IN TENNESSEE PORTION OF REGIONAL STUDY AREA . . . . . . . . . . . . . XIII-2

XIII-2 GENERALIZED LAND USE IN DEKALB COUNTY WITH THE PROJECT . . . . . . . . . . . . . . . . . . . . XIII-87 
SECTION VII

INTRODUCTION

Information presented in Volume II of this report characterizes the major baseline environmental features of the Chattanooga Shale study area as delineated in Section $I$ and projects the general nature of the effects upon these features which may accrue from implementation of a large scale development to recover uranium from the shale in this area. As documented in Section $I$, the present status of the data defining shale uranium content in the regional area overwhelmingly identifies southeastern DeKalb County as the logical target area for initial recovery operations. This is not to suggest that a variety of other areas, within (or without) the delineated study region may not in fact be underlain with shale as high or even higher in uranium content than that in the DeKalb County area. It simply has not been established at this juncture whether or not this is the case.

Since the actual distribution of uranium values within the region is poorly defined, the extensive body of data for the DeKalb County locale dictates that the selection of a theoretical project site therein is most appropriate to the purposes of this report. Based on considerations of topography and known geographical concentration of favorable uranium values, the theoretical siting of the project for this impact analysis is as shown in Figure VII-1. The site is defined as the Youngs Bend area between Fall Creek and Pine Creek from the Evins Mill Pond southeastward to Center Hill Lake. It is emphasized that the specific locating of the underground mines and surface processing facilities is intended to serve only as a point of discussion. Once a more thorough knowledge of areal uranium distribution exists, several locations may emerge as equally attractive from a strict operational. and recovery standpoint, and quite possibly more attractive from an environmental standpoint. 


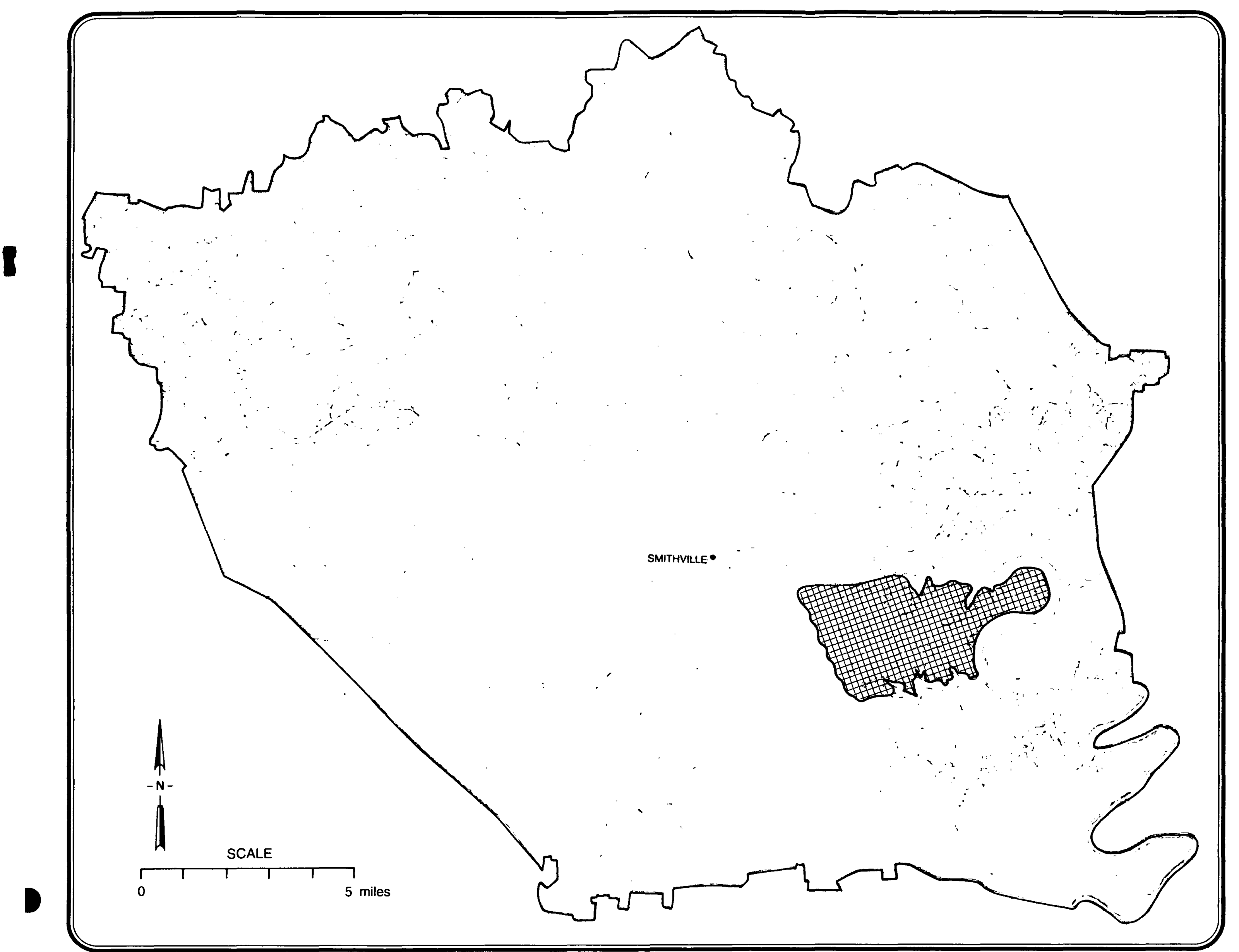

PROTOTYPE PROJECT
LOCATION IN LOCATION IN
DEKALB COUNTY

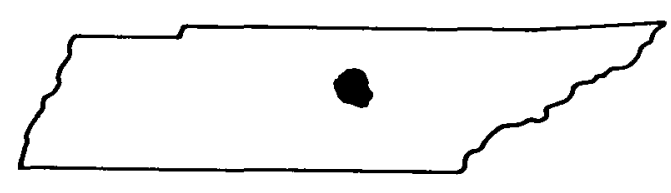

KEY

Prototype Project

FIGURE VII-1 
Although there are a great number of uncertainties in the ultimate project design, any initial environmental feasibility document must address itself to some fixed prototype project description that encompasses a realistic spectrum of potential impacts. The following discussion is based upon a synthesis of "typical" project designs that utilize large raw shale ore throughputs, and site-specific parameters tailored to the constraints introduced by the physical characteristics of the Gassaway Member. Pertinent design and impact assumptions for a mining and processing complex of the nature envisioned by this study are summarized for illustrative purposes as follows (see Volume I for greater detail):

- Begin construction -- 1983

- Maximum construction activity -- 1987 to 1988

- Commence production phase -- 1990

- Project operational life -- 20 years

- Total Capital Cost of Operation -- \$2.3 billion

- Number of construction workers -- 4,000

- Number of operations personnel --3,000 (2,400 mining and 600 processing)

- Mining method -- "room and pillar"

- Mining depth -- 100 to $500+$ feet below surface

- Underground area mined -- 750 acres per year (total acreage, approximately half of which remains unmined)

- Processing throughput -- 100,000 tons per day

- Shale thirkness -- 16 feet

- Shale density - $144 \mathrm{lbs} / \mathrm{cu}-\mathrm{ft}$

- Ore uranium content -- 55 ppm

- Ore oil content -- 10 gallons per ton [Fischer Assay] (hydroretorting yield expected to equal up to $250 \%$ of assay value)

- Mining recovery efficiency -- 60 percent

- Uranium recovery efficiency -- 60 percent

- Uranium production -- 3+ tons per day

- Oil recovery efficiency -- 1/2 barrel per ton of shale

- Number of mine sites -- 3 
- Number of processing plants -- 1

- Total surface area covered by facility -- 6,000 acres

- Tailings surface disposal volume -- 4,000 acre-ft per year (assuming that available technology will permit reintroduction of 70 percent of tailings back into mine, leaving 30 percent to be stored on land)

It has been estimated that five production complexes such as described above would be necessary to satisfy approximately 25 percent of the Nation's present uranium demands. It is conceivable therefore that the regional area considered herein may ultimately experience this level of development. However, since the impact of any one operation would be very similar to the impact of another, this study concentrates upon identifying the potential environmental impacts of one mining and processing complex. Based upon the operational characteristics outlined above, one production complex with a 20-year life span will mine 1,5,000 acres (approximately 25 square miles) and produce approximately 80,000 acre-feet of tails requiring surface storage. Assuming a tailings impoundment depth of 100 feet, the tailings will require a disposal area of approximately 800 acres.

Due to the highly theoretical nature of the project at this point in time, much of the impact analysis executed in this study assumes the character of a "model" for impact assessment of large-scale uranium recovery from the area in question. This is to. say that in many instances, the approach taken by the report is to present a thorough methodology for assessing the impacts of such an operation within the study area, rather than presenting an extremely detailed locationspecific impact analysis. Accomplishing the latter is simply beyond the scope of this study. The regional area under consideration is vast, and in tact, in terms of examining fine detail, an area the size of DeKalb County is even outsized.

Classic environmental impact statements are by their nature site and project specific. The absence of both of these specifics positions this study squarely in the realm of the conceptual rather than the absolute. Therefore, rather than a specific impact, quite often a type 
of impact will be identified in concert with a discussion of the methodology by which this impact type may be quantified when site and project particulars are known.

Though the regional study area is broadly characterized in terms of all important environmental elements and DeKalb County is described in substantial detail, greater specificity and detail of data would be required for preparation of a formal Environmental Impact Statement. Characterization of the regional study area has posed a particularly challenging problem since most agencies and literature holding the necessary data are delineated by political or geographic boundaries whereas the study area is defined by a rather arbitrary boundary that spans both the political and geographic boundaries. At best this presents a problem with standardization of data to a consistent level of organization and detail from one area to another; at worst, it presents a situation wherein certain data may be available for one area and completely absent from another. This problem is especially prevalent when crossing state boundaries. 


\section{SECTION VIII \\ PHYSIOGRAPHY AND GEOMORPHOLOGY}

The following account briefly characterizes the major geomorphic features of the regional study area and DeKalb County. This discussion is limited primarily to the consideration of features which relate directly to the hydrologic and biologic character of the area, as discussed later. For a detailed treatment of the geology of the Chattanooga Shale, the reader is referred to Section II of this report.

\section{REGIONAL CHARACTERIZATION}

The topography of the regional study area is quite varied, stretching from the lowlands toward the Mississippi Valley to the west, and to the mountains and knobs of the Cumberland Plateau to the east. Elevations range from less than 400 feet along the riverbottoms of the Cumberland and Tennessee Rivers in the western portion, to well over 3,500 feet in the east. The area is characterized by gently rolling hills that rise sharply on the Cumberland Plateau and then drop back down into the Great Valley (Sequatchie Valley) of the East Tennessee River. Figure. VIII-1 shows the designation adopted in the four-state regional area for the important physiographic regions comprising the shale resource development study area. General topographical characteristics of each of the main areas are summarized below, beginning with Kentucky and proceeding to Tennessee and Alabama and Georgia (all heights are above mean sea level).

The Mississippian Plateau Region is marked by level farmland and undulating to rolling hills. A few sharply rising hills often contain numerous limestone sinks and caverns due to subsurface drainage. Elevations are typically 600-700 feet, gradually rising to 900-1,000 feet approaching the hills to the east. Kentucky's highest elevations in the regional study area are found approaching the Eastern Mountains, an 


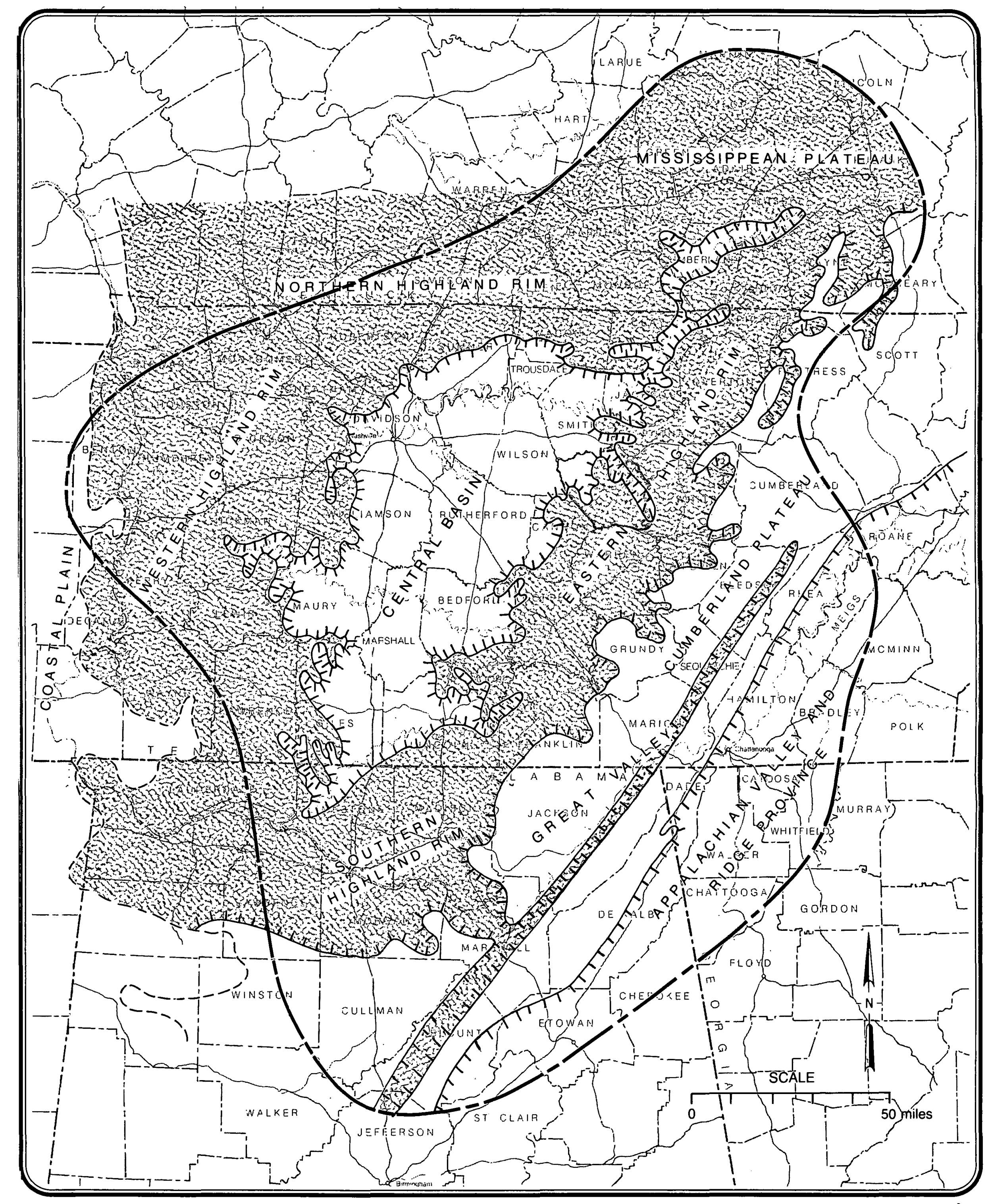

CHIEF PHYSIOGRAPHIC FEATURES OF REGIONAL STUDY AREA

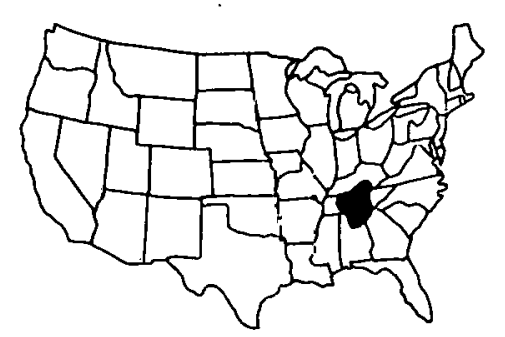


extension of the Cumberland Plateau. Elevations in the eastern counties rise to 1,200 feet or more with considerable sharpening of the ridges and valleys compared to further west.

Central Tennessee contains a relatively homogeneous area known as the Central Basin (Nashville Basin). The area is drained principally by the Cumberland River and its tributaries. Elevations within the rolling plain comprising the Central Basin average 600 feet, except for a cluster of hills south of Nashville with elevations of over 1,000 feet. Surrounding the Central Basin is a hilly crescent touching the Tennessee River to the west and Cumberland Plateau to the east, designated the Highland Rim. The rim ranges from about 600 feet along the river to the west, to about 1,000 feet in the east.

The eastern portions of the rim rise abruptly into the Tennessee portion of the Cumberland Plateau. The plateau, with average elevations of 2,000 feet, extends roughly northeast-southwest across the state and is typically 40 miles wide. Maximum elevations along the Walden Ridge, the main spine paralleling the plateau, extend to over 3,000 feet.

Within ten miles of the highest points in the plateau, elevations drop sharply to the Great Valley of the Eastern Tennessee River. The river drops 1,500 feet in the northeast part of the state and levels off at about 700 feet within the study area.

Alabama and Georgia are both characterized by rolling terrain in the Appalachian Valley and Ridge Province that rises from 400 feet, south of Birmingham, to 1,000 feet as the terrain ridges into the Cumberland Plateau at the Alabama, Georgia, and Tennessee boundary.

\section{SOILS}

Three major soil orders (Ultisols, Alfisols and Inceptisols) are found in the regional study area, as delineated in Figure VIII-2. The composition and characteristics of these major soil associations and their subunils shown in the Figure are presented in Appendix B. 


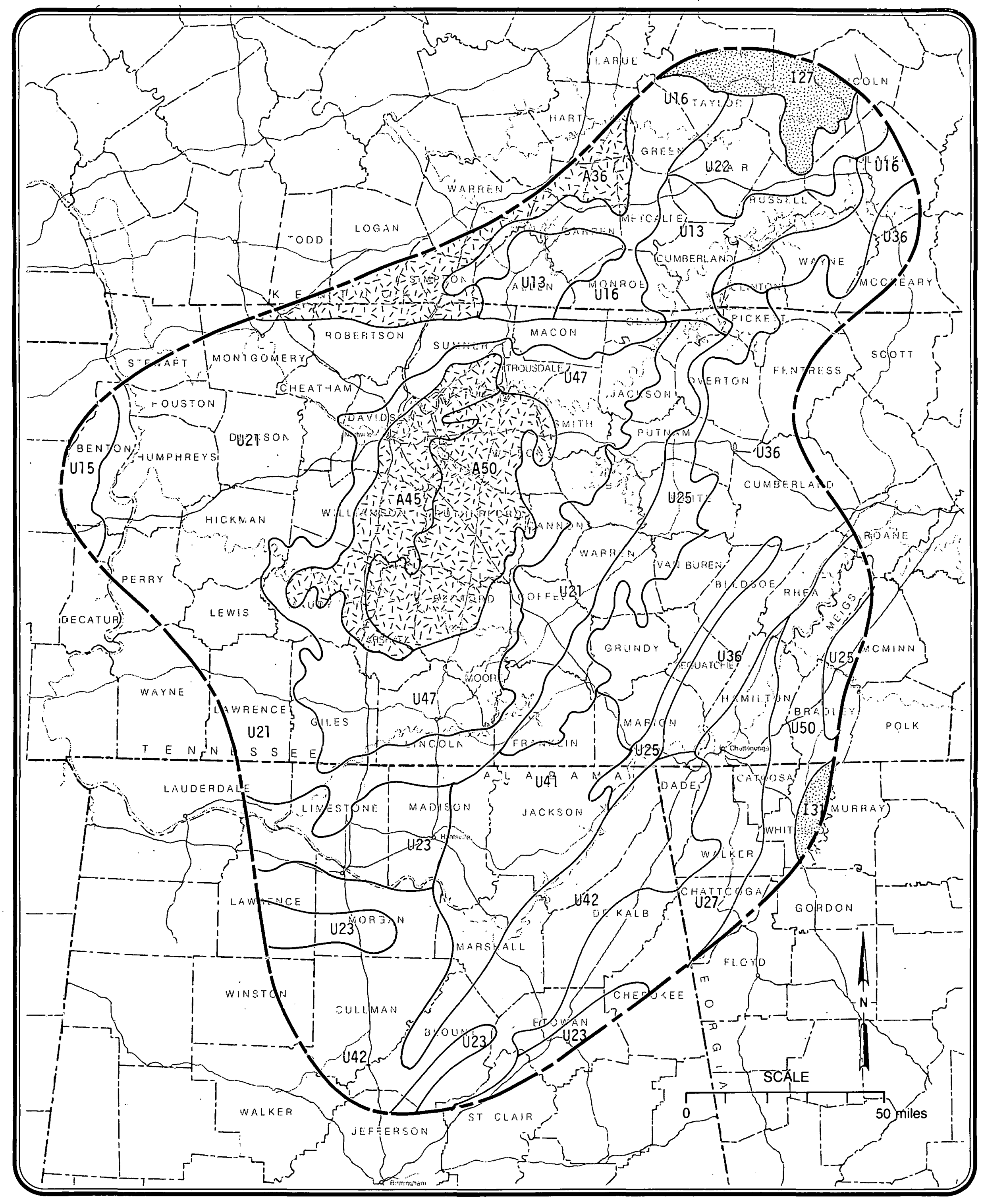

SOILS OF THE REGIONAL STUDY AREA

KEY

圆

ALFISOLS

A36 Pal leudalfs, Pal eudults
A45 Hapludalf $f$, Pal eudults, Hapludult ts

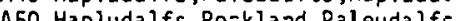

IMCEPTISOLS

I27 Eutrochrepts, Dystrochrepts

131 Dystrochrests, Hapludults, Hapl Imbrepts

ULTISOLS

U13 Pal eudults, Eutrochrepts, Hapludult ts

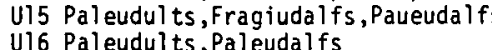

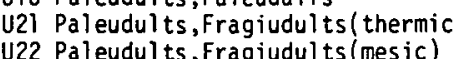

U23 Paleudults, Fragiudul ts, Pal eudalfs

U25 Paleudults, hapludults

U27 Pal eudul ts, Hapludul ts, Fragiudul ts

U36 Hapludults, Dystrochrepts (steep)
U41 Hapluduilts, Dys trochrepts, Pal eudal fs

U42 Hapludui ts, Dystrochrepts, Pal eudul ts

U47 Hapludul ts, Hepludal fs, Pa eudults
uso Hapludul ts, Pei eudults, Dys trochrepts

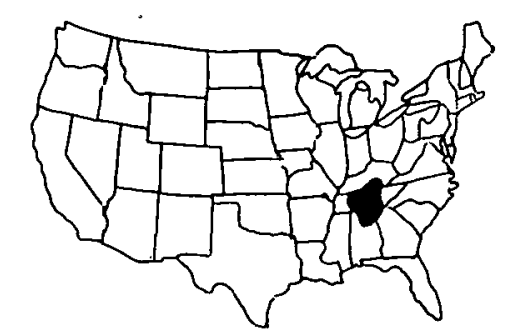

FIGURE VIII-2 
U1tisols are light-colored rocks of warm-temperate forest lands and are predominant in the study area. Oak-hickory forests are the native vegetation of these soils. The acid and relatively infertile Ultisols are represented within the study area by two major subunits: Paleudults and Hapludults.

Natural fertility in Paleudults is uniformly very low. The Paleudults exhibit good physical qualities and low volume change on wetting; the soil is commonly six to ten feet thick to the base of the B horizon. Hapludults occur extensively in the areas that are underlain by consolidated rocks, either sedimentary, igneous, or metamorphic, and generally occupy rolling to steep topography. The soils show good physical qualities . and usually low volume change on wetting. Although natural fertility is not as low as in the Paleudults, the Hapludults nevertheless are moderately to strongly acid. The soil ranges from a few inches to about five feet in thickness and is free-draining.

Alfisols are located in the Nashville Basin and in the northwest portions of the study area. These soils are light-colored and characteristic of humid-temperate areas. They are typically acid but contain a moderate to high level of calcium, magnesium, and other elements essential to plant growth. The soils are moist during at least three months of the seasonal period sufficiently warm for plant growth.

Inceptisols are found along the southeastern and northern borders of the study area. The Inceptisols in the study area are shallow soils located on steep slopes. Mixed hardwood forests are the native vegetation of these soils. Most are well-drained and many contain gravel and rock fragments. The acidity of these soils varies with their location.

\section{LOCAL CHARACTERIZATION}

DeKalb County lies within the Central Basin (Nashville Basin) and the Highland Rim physiographic provinces of Tennessee. As indicated in Figure VIII-3, the western tip of the county is part of the basin topography and the eastern remainder of the county is in the higher elevation 
of the flat-lying rim topography. DeSelm [1959] divides DeKalb County the three physiographic areas depicted in Figure VIII-3: Dissected Eastern Highland Rim, Undissected Eastern Highland Rim, and Outer Central Basin.

As shown, the Undissected Rim breaks abruptly along a very uneven line which runs from northeast to southwest and whose center in the county is about five miles west of Smithville, at Snow's Hill. West of the line lies the dissected portion of the Rim, characterized physiographically by rim spurs, deep irregular valleys, and high randomly placed hills whose crests are upheld by the same resistant strata that maintain the integrity of the Undissected Rim. The bulk of the surface of the Dissected Rim is directly underlain by rapidly disintegrating limestone and is edaphically very dissimilar to the Undissected Rim.

DeKalb County is bordered on the north by Smith County and Putnam County; on the east by White County; on the south by Warren County; and on the west by Cannon County and Wilson County. Smithville, the county seat, is located in the south-central part of the county on the Highland Rim, and is 65 miles east of Nashville. The area of the county is 317 square miles, of which 39 square miles is water acreage of Central Hill Lake.

\section{GEOLOGY}

DeKalb County is underlain at the surface by rock formations of Ordovician, Devonian, and $\mathrm{M}^{*} \mathrm{ssissippian}$ age. The older Ordovician limestones underlie the western one-third of the county and comprise the area known as the outer Central Basin. The dissected valleys of the Highland Rim also are underlain in part by limestone formations of Ordovician age. These limestones are generally dense, flat-lying formations, and the formations which occur at lower elevations in the basin area are relatively free from the siliceous matter and nodules which characterize some of the younger Ordovician limes at higher elevations in the basin and dissected valleys . 


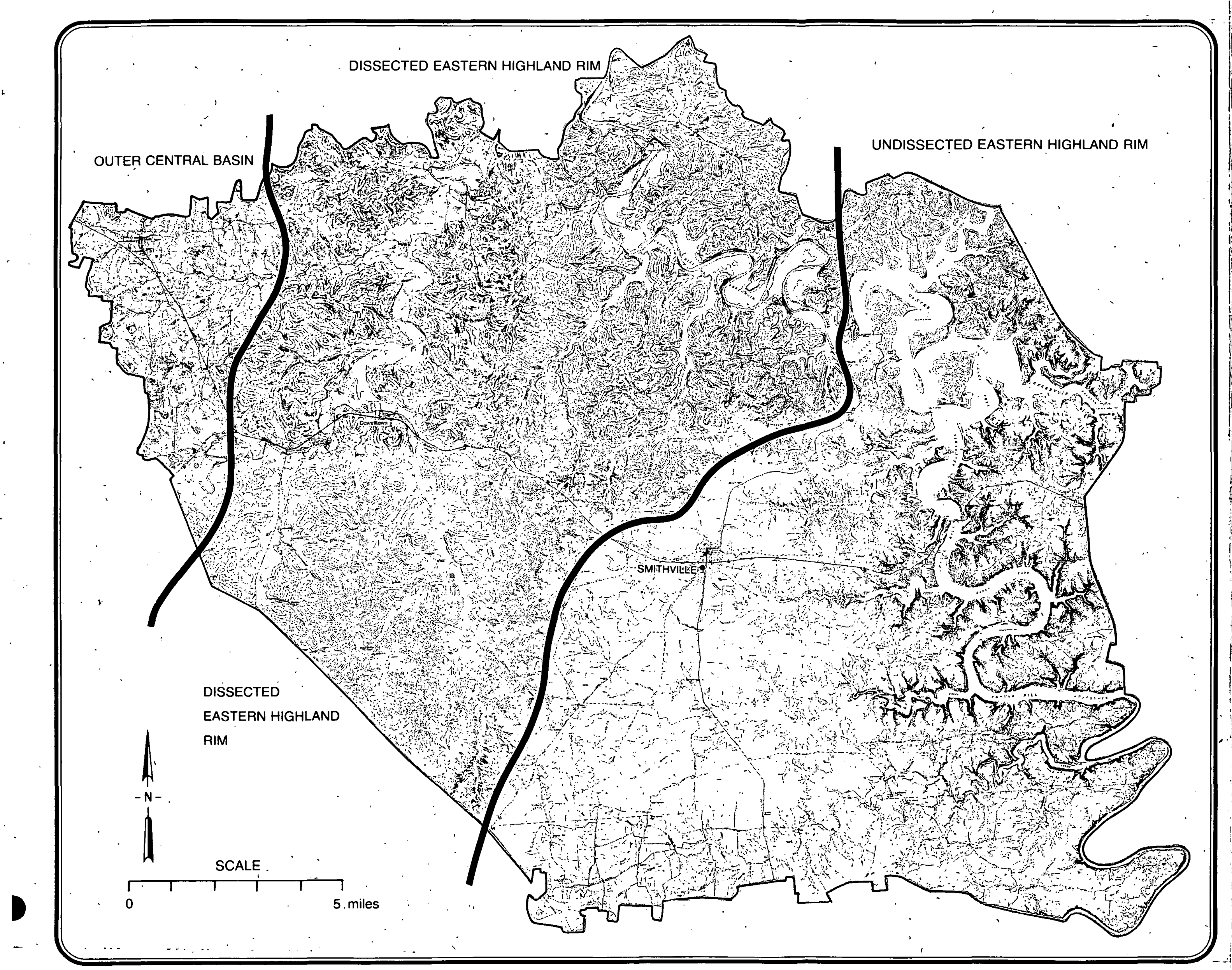

MAJOR PHYSIOGRAPHIC SEGREGATIONS OF DEKALB COUNTY

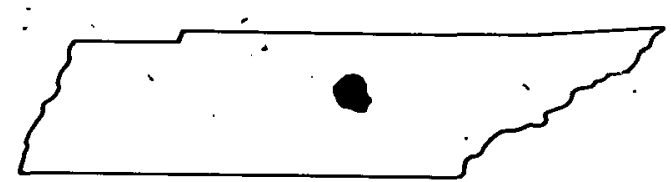

FIGURE VIII - 3 
The Devonian formations are represented by the Chattanooga Shale which occurs at the surface in the upper elevations of the dissected valleys between the basin and the rim. The Chattanooga formation is sandwiched between the underlying limestone units of Ordovician age and the overlying Maury Shale and Fort Payne Limestone of Mississippian age. The shale underlies most of the county where the surface formation is of Chattanooga or post-Chattanooga age.

The Mississippian formations which underlie the Highland Rim section of the county are characterized by cherty and blocky-type limestones along with the more massive-bedded limestones. Depending upon the location, the Mississippian section ranges from a few feet to more than 200 feet thick in DeKalb County.

Following is a brief description of the major formations representing the Ordovician, Devonian, and Mississippian ages within DeKalb County. These formations are considered in much greater detail in Section II.

\section{Ordovician Formations}

The Lebanon, Carters, and Hermitage Formations, the oldest rocks in the area, occur at lower elevations in the area of Dowelltown, Liberty," and Alexandria in the basin area. These dense limestones underlie the Bigby-Cannon and Catheys-Leipers limestone formations which occur at the medium and higher elevations in this section of the county. In the eastern two-thirds of the county the Catheys-Leipers formations are the only Ordovician formations exposed at the surface except where the Cannon member of the Bigby-Cannon limestone is partially exposed at lake elevation in places.

Within the context of uranium mining and its impact upon the environment the Bigby-Cannon Limestone is the oldest geologic unit which is of significance, and therefore it is the lowest unit by elevation which is to be described herein in any detail. The formation occurs locally at lake level in the Center Hill area and is present in most places beneath the surface elevation of the lake, which is approximately 650 feet above 
sea level. The Cannon member, the upper unit, is the only exposed section of the formation, and its maximum thickness, exposed and beneath the surface, is approximately 90 feet. The Cannon is medium-dark gray and dark gray to brownish gray, microcrystalline to medium-grained, and medium-bedded.

The Catheys and Leipers formations are normally mapped inclusively, the Catheys being the older unit. The Leipers-Catheys is exposed in the dissected valleys where the formation is in contact with the overlying Chattanooga Shale. Its thickness ranges from 175 to 275 feet. The Leipers-Catheys is a dark gray limestone which weathers to a pale yellowish brown. It is a fine-grained, thin- to medium-bedded limestone, argillaceous and nodular, with shaly partings, and is locally fossiliferous. It is crypto-crystalline and breaks with a conchoidal fracture.

\section{Devonian Formation}

The Chattanooga Shale occurs at the base of the Mississippian age formations and is generally considered to be Devonian in age. Its thickness ranges from 20 to 35 feet. The Chattanooga is carbonaceous, grayish-black, thinly laminated and fissile. The upper part (Gassaway member) is slabby and blocky and is characterized by linear fracturing. The lower part (Dowelltown member) is crumbly and less supportive.

\section{Mississippian Firmations}

The Mississippian Fort Payne Formation overlies the Chattanooga Shale throughout DeKalb County, and generally ranges in thickness from 150 to 250 feet. The Maury Shale member, a green glauconitic mudstone, one to four feet thick, occurs at the base of the Fort Payne. Generally the Fort Payne is a fine- to medium-grained argillaceous limestone which weathers to a yellowish-brown or a reddish-brown rubble of blocky and irregular fragments of porous. chert. The Fort Payne soil cover ranges from a cherty porous type at the steeper elevations to a reddish-gray clayey loam in the flatlands. 
The Warsaw Formation which overlies the Fort Payne does not occur at many places in the county and is of little significance to the project under consideration. Its thickness is seldom more than 50 feet where exposed. The Warsaw is a dark- to medium-gray limestone which is fineto coarse-grained and medium- to thick-bedded. Locally it is fragmented by crinoid fossilization. The weathered formation is also characterized by angular chert blocks which are reddish-brown. The soil residue is a flaky to sandy shale.

\section{SOILS}

The general soil associations of DeKalb County are shown in Figure VIII-4. Soils associated with the Highland Rim are mainly silt loams or cherty silt loams. Some of the soils are poorly drained and may have a dense compact layer at about two feet below surface. Erosion of the surface of the Highland Rim formed the Central Basin, which is underlain by bedrock. Soils in the Central Basin are well drained and high in phosphorus. 


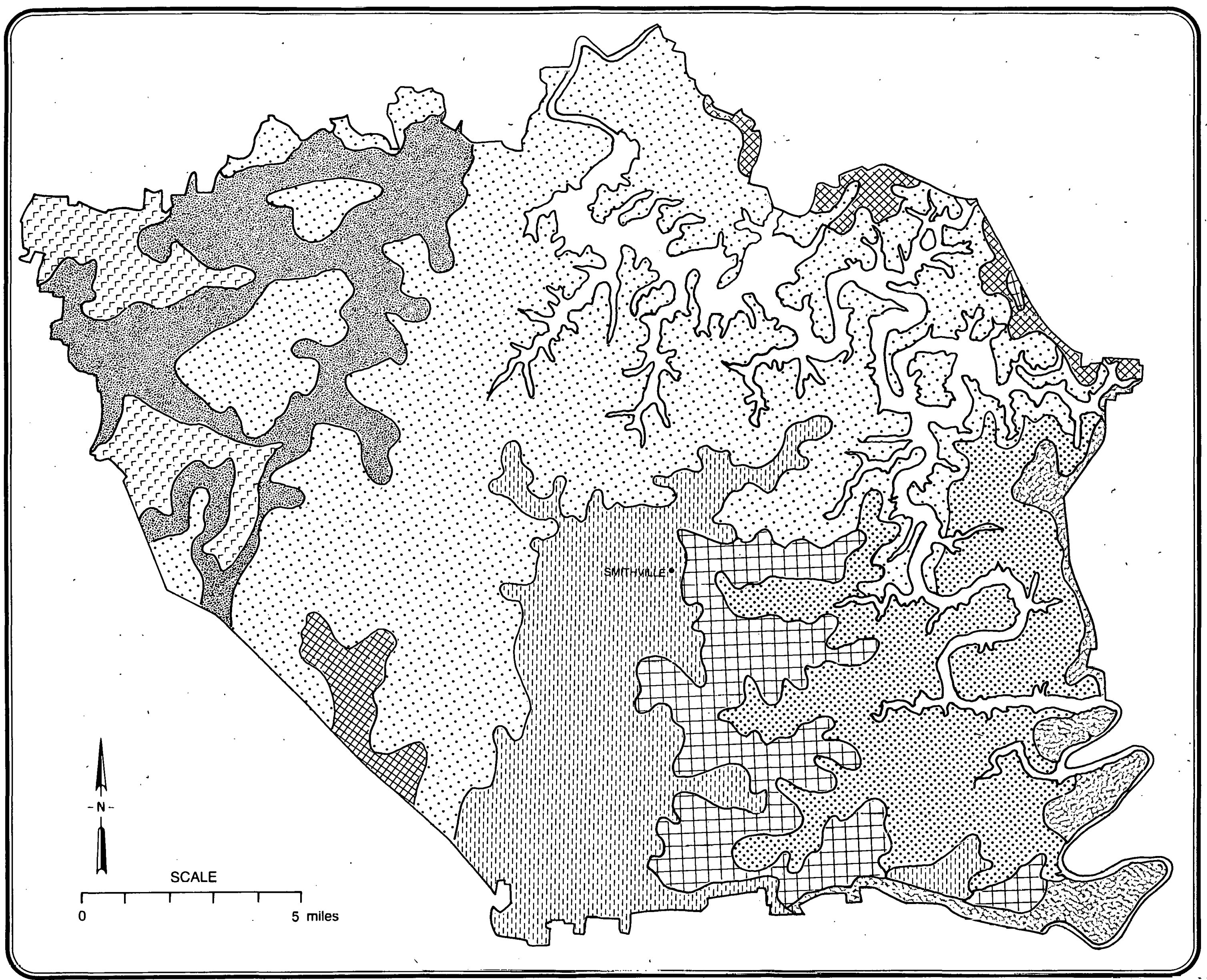

GENERAL SOIL MAP

OF DEKALB COUNTY

(adapted from USDA - Tennessee Agricultural Experiment Station map)

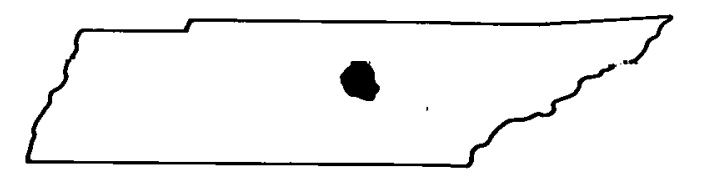

KEY

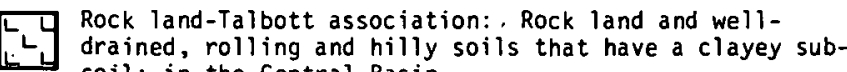

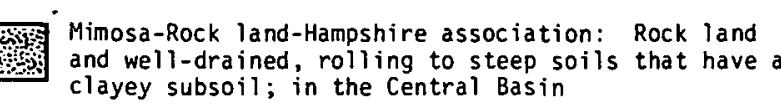

Bodine-Minosa-Dell rose association: Excessively

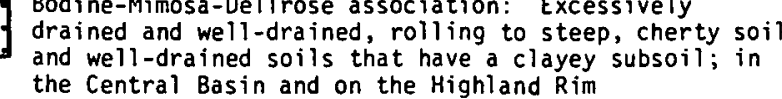

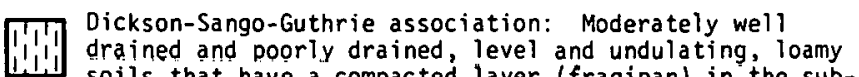

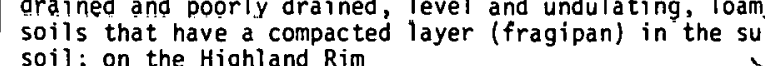

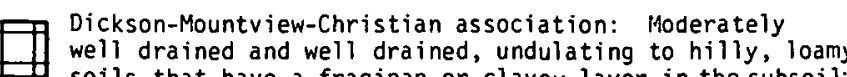

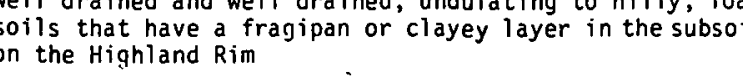
Christian-Bodine association: yel1-drained, rolling to
hilly soils that have a clayey subsoil and excessively

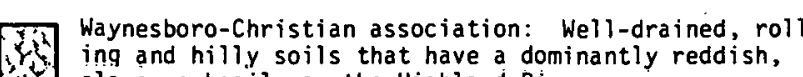
oodine-Ful erton association: Excessively drained and
welly-dra ined, rolling to steep, cherty soils; on the
Highland Rim

FIGURE VIII-4 


\section{SECTION IX \\ CLIMATOLOGY AND METEOROLOGY}

The principal intent of this section is to provide a context for the analysis of air quality impacts presented later in this report. Climatic and meteorologic descriptions are provided for both the regional and local levels.

\section{REGIONAL CHARACTERIZATION}

The following narrative presents a generalized description of the climatic and atmospheric character of the regional study area. The climate is characterized in terms of temperature and precipitation patterns that have prevailed over the past several years in the area. Storm patterns are also discussed. Particular attention is devoted to a characterization of the windfield structure and atmospheric stability, as these two parameters play a governing role in defining regional atmospheric pollution potential.

\section{TEMPERATURE}

In general, the climate of the area is very warm in the summer and highly variable in the winter. Long, sultry summer hot spells and several very cold winter axctic outbreaks are interspersed within a relatively mild and pleasant climate. The principal controlling features of the temperature distribution are the regional topography, the mean position of the synoptic-scale mid-latitude storm track, and the exact location of the sub-tropical high pressure center east of Florida. Differences in insolation, proximity to the Gulf of Mexico, and synoptic flow patterns create a general gradation of average temperatures across the study area. 
Average temperatures in Kentucky are as much as $8^{\circ} \mathrm{F}$ colder than the southernmost portions of the Chattanooga Shale resource area in Alabama. Elevated terrain further complicates any regularity in the isotherm patterns since temperatures decrease with elevation at approximately $3^{\circ} \mathrm{F}$ per 1,000 feet increase in elevation. Temperature patterns in the Cumberland Plateau, the Great Valleys, and the Smokies further east are therefore far more complicated than in the more regular terrain in the western portions of the area under consideration.

Regional temperature distributions have been determined from climatic summaries for each of the four states in the mesoscale study area. Data from 51 climatic stations have been tabulated and plotted for analysis. The regional temperature distributions from the 51 stations shown in Figure IX-1 have been analyzed for mean daily maxima, minima, and annual average temperature. Although temperature extremes are an important aspect of the regional temperature structure, differences in the length of records from various stations imply that not all extremes were sampled by each station and they therefore have not been analyzed in the same detail as the means.

Figure IX-2 demonstrates the dominant role of topography in redirecting the prevailing north-south temperature gradient. The average annual temperature decreases gradually from $64^{\circ} \mathrm{F}$ in Alabama to $56^{\circ} \mathrm{F}$ on the Cumberland Plateau and the hills of southeastern Kentucky. Since the elevated stations are located at about 1,000 feet above stations in the Central Basin, Yighland Rim, and Mississippian Plateau Region, indicated differences of $3^{\circ} \mathrm{F}$ between identical latitude stations bear out the conclusion that the altitude effect in the study area is about $3^{\circ} \mathrm{F}$ per 1,000 feet.

Mean daily maxima and minima shown in Figures IX-3 and IX-4 also reflect the ubiquitous influence of terrain. The higher elevations on both sides of the Great Valley exhibit temperatures that are almost $5^{\circ} \mathrm{F}$ cooler during the hottest part of the day. The minima in Figure IX-4 are even more complex because colder air drains down from higher elevations and pools in low flat spots. Exposure differences of a few 


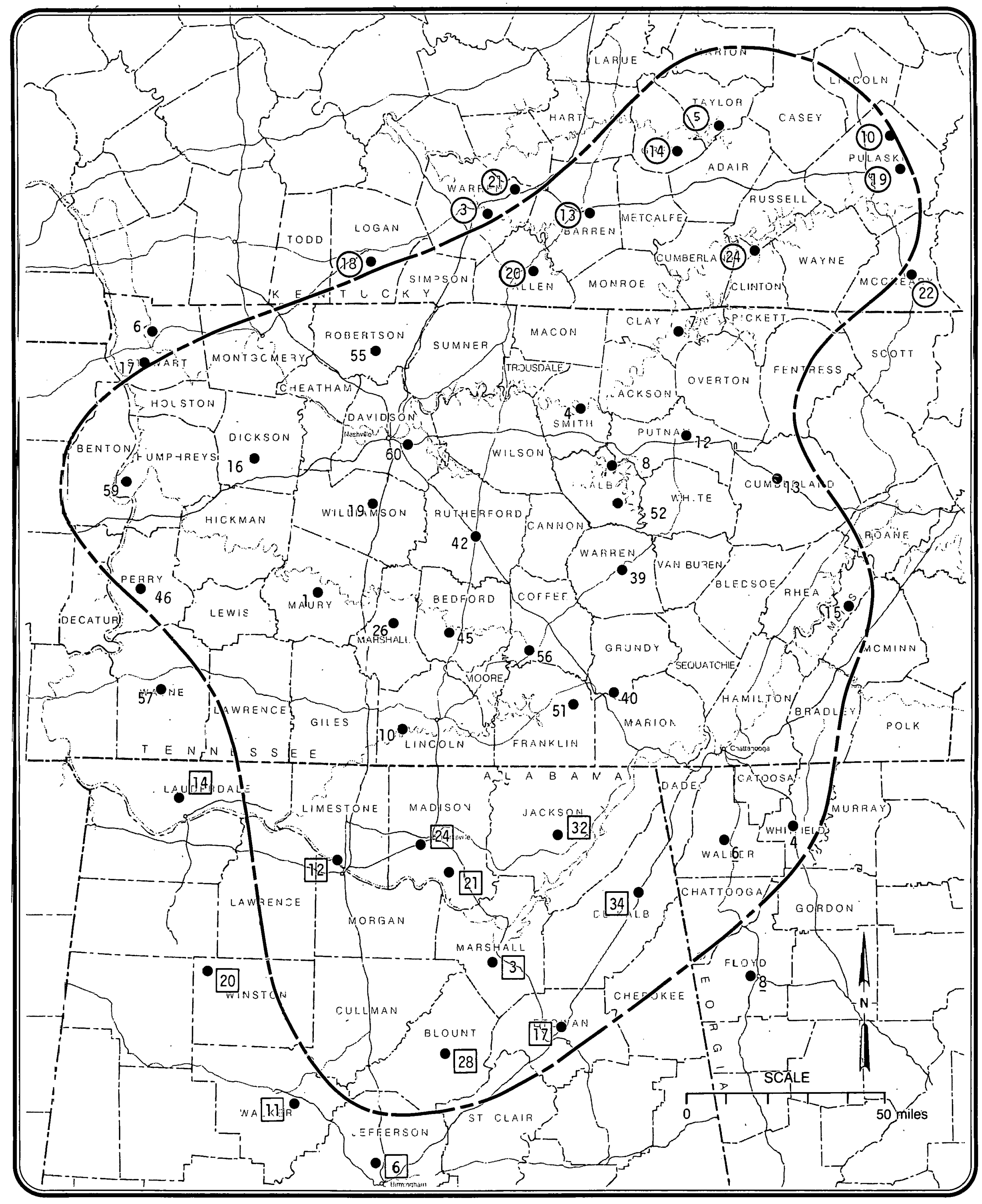

TEMPERATURE DATA SOURCES IN THE REGIONAL STUDY AREA (refer to Appendix C for station identification) KEY

- Climatic Station Location

26 Station Identifier - Tennessee

(21) Station Identifier - Kentucky

24 Station Identifier - Alabama

$\underline{6}$ Station Identifier - Georgia

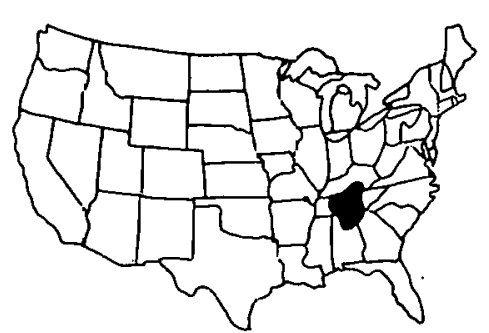




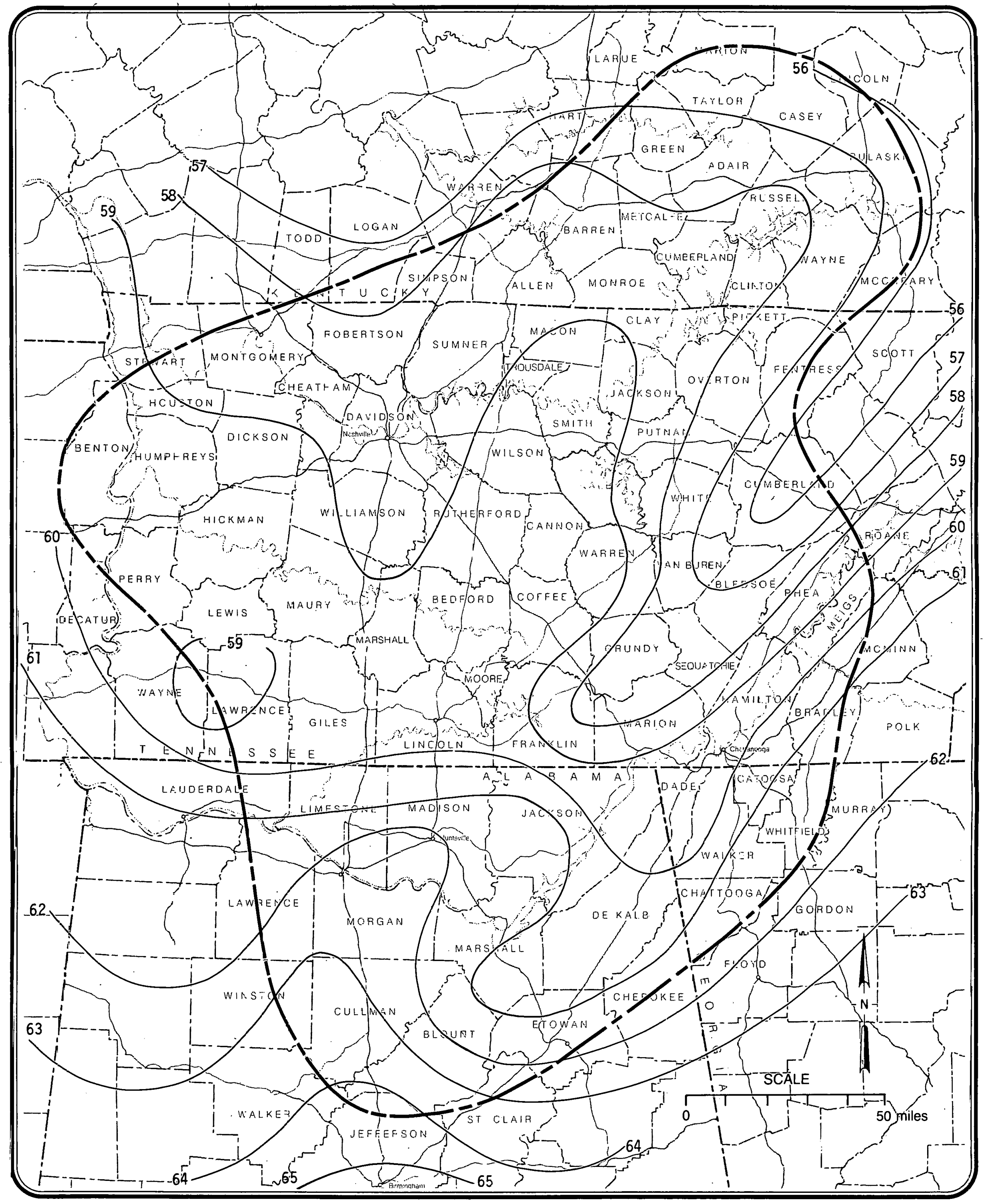

AVERAGE ANNUAL TEMPERATURE IN THE REGIONAL STUDY AREA

KEY

61 Temperature ( ${ }^{\circ} \mathrm{F}$ )

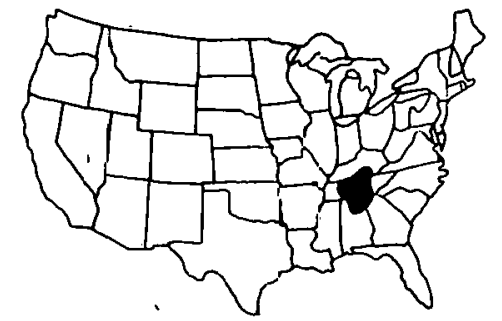




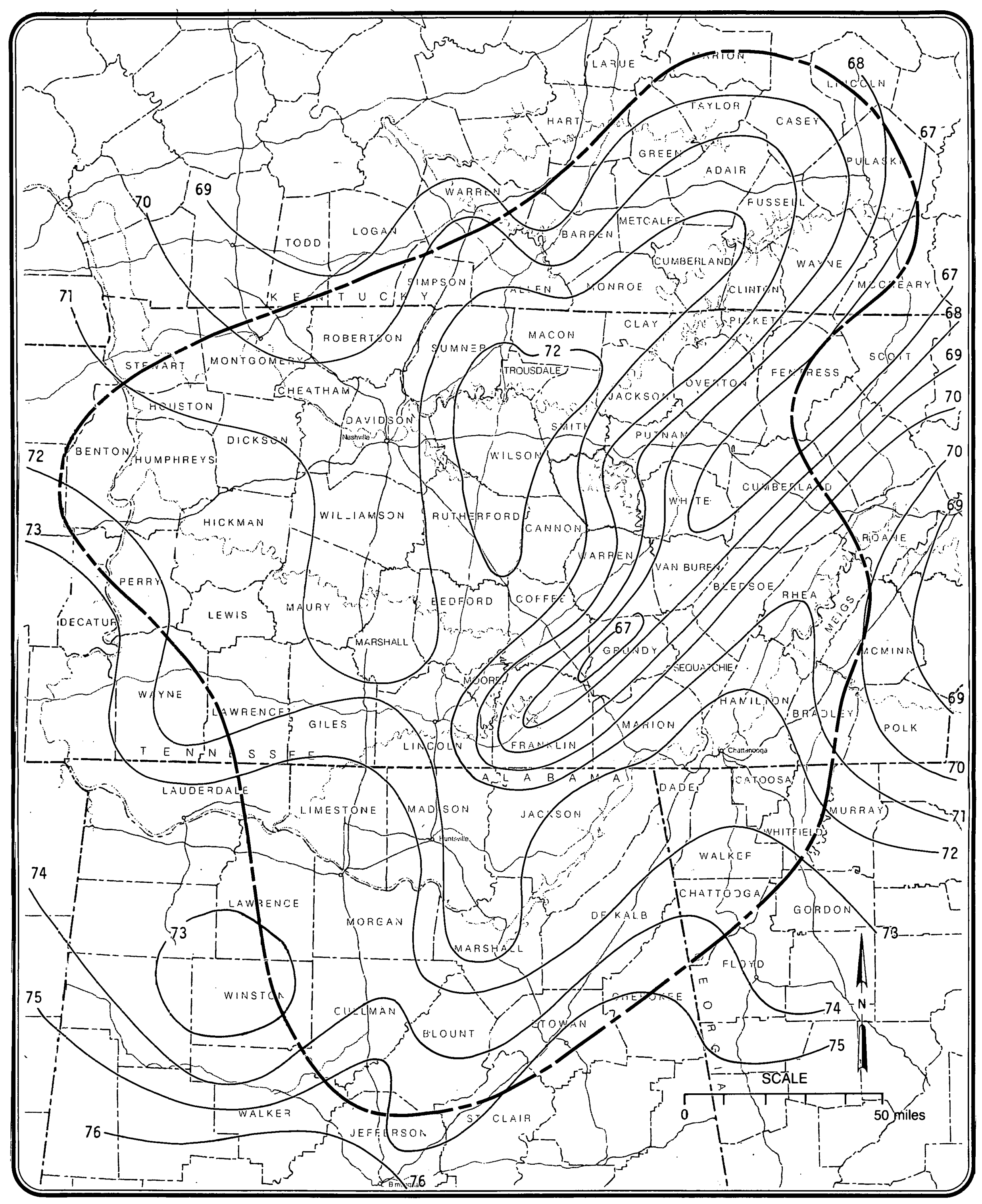

DAILY MEAN MAXIMUM TEMPERATURE IN THE REGIONAL STUDY AREA

$\underline{\text { KEY }}$

70 Temperature $\left({ }^{\circ} \mathrm{F}\right)$

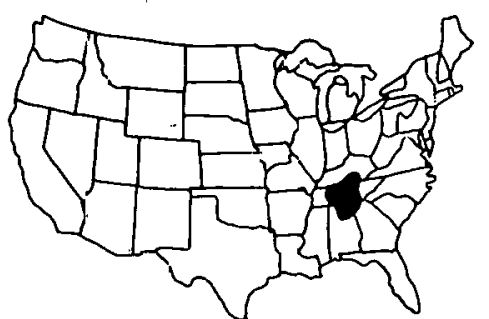




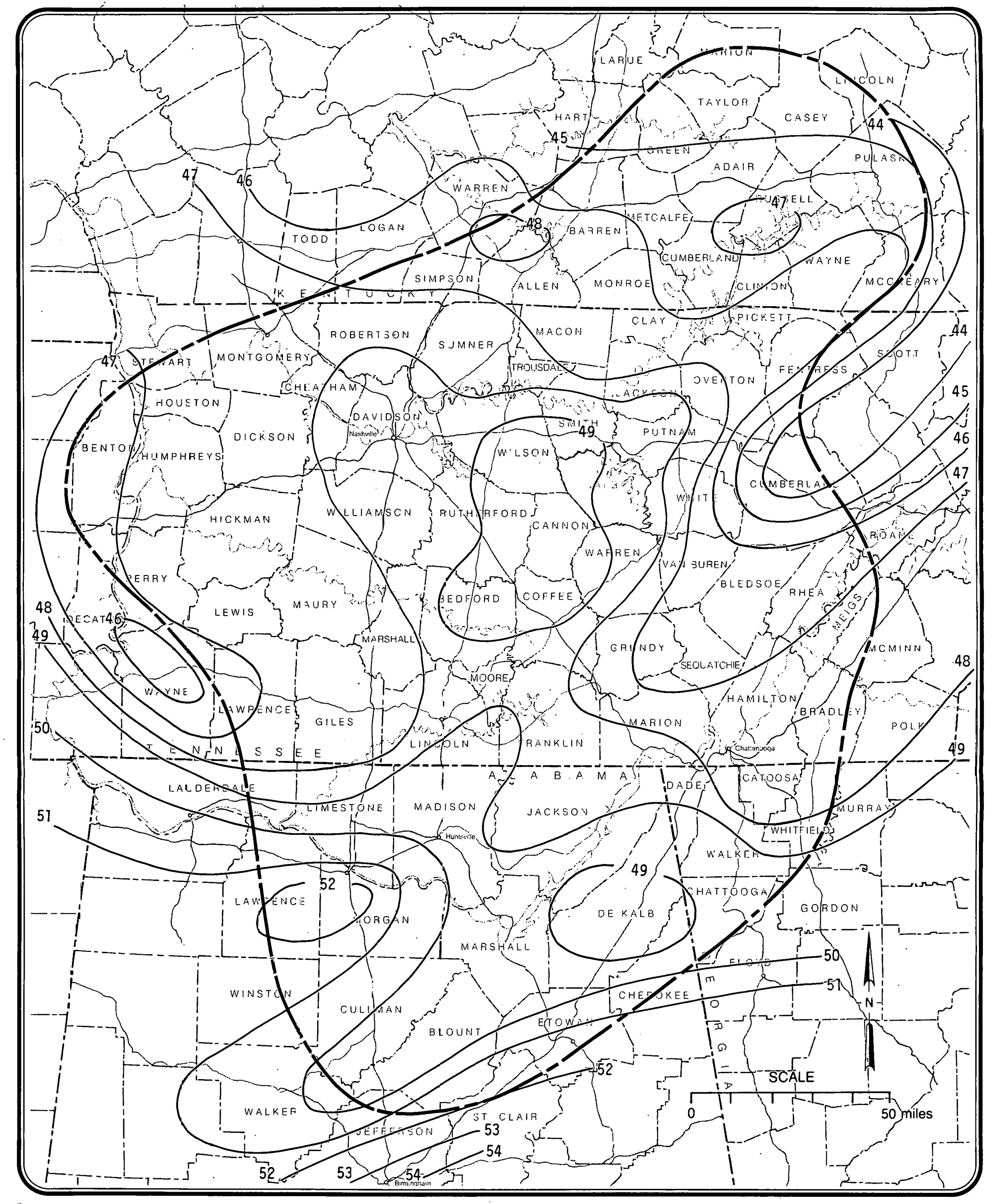

DAILY MEAN MINIMUM TEMPERATURE IN THE REGIONAL STUDY AREA

$\underline{K E Y}$

46 Temperature ( $\left.{ }^{\circ} \mathrm{F}\right)$

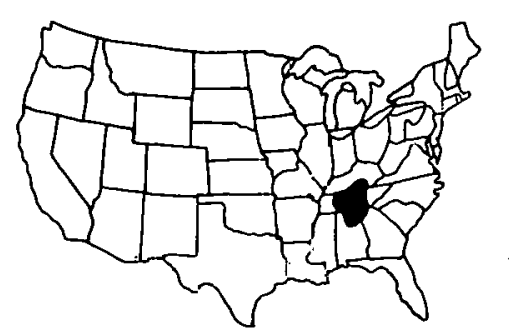


miles can produce dramatic differences in the mean minimum temperature. Consequently the results in Figure IX-4 should not be applied too generally, but rather be considered indicative of more site-specific phenomena.

The general temperature pattern disclosed by the figures just discussed constitutes an average temperature in the center of the study area of about $60^{\circ} \mathrm{F}$, with temperatures $2-3^{\circ} \mathrm{F}$ higher to the south and $2-3^{\circ} \mathrm{F}$ lower to the north. Maxima average about $71^{\circ} \mathrm{F}$ and minima about $49^{\circ} \mathrm{F}$ with similar north-south latitudinal effects. Temperatures on the Cumberland Plateau drop about $3-4^{\circ} \mathrm{F}$ from this general pattern and complexity in the isotherm distribution increases as one proceeds through the Great Valley and into the Smokies.

Temporal temperature patterns depicted in Figures IX-5 and IX-6 for Nashville and Chattanooga indicate a definite climate homogeneity for stations of similar elevations throughout the region. Although the Chattanooga station (elevation 670 feet) is surrounded by more complex terrain, Nashville (elevation 580 feet) is only slightly warmer in summer and cooler in winter, such that average temperatures for the two stations are almost identical. Arctic outbreaks are slightly more severe in Nashville with absolute minima slightly lower than Chattanooga $\left(-13^{\circ} \mathrm{F}\right.$ versus $\left.-10^{\circ} \mathrm{F}\right)$, but summer heat waves are the same at each location with all-time highs of about $106^{\circ} \mathrm{F}$. The diurnal range of temperature at each location is again equal with $18-20^{\circ} \mathrm{F}$ differences between winter minima and maxima and $22^{\circ} \mathrm{F}$ differences in the summer.

To summarize, except for physical differences in terrain or significant latitude separation, the climate of the mesoscale area appears to be relatively uniform based upon the spatial and temporal temperature distributions.

\section{PRECIPITATION}

Precipitation data are available from a much denser network of recording stations than true for temperature. Both large-scale features and small-scale unique characteristics of the precipitation field can be 


\section{NASHVILLE ANNUAL TEMPERATURE DISTRIBUTION}

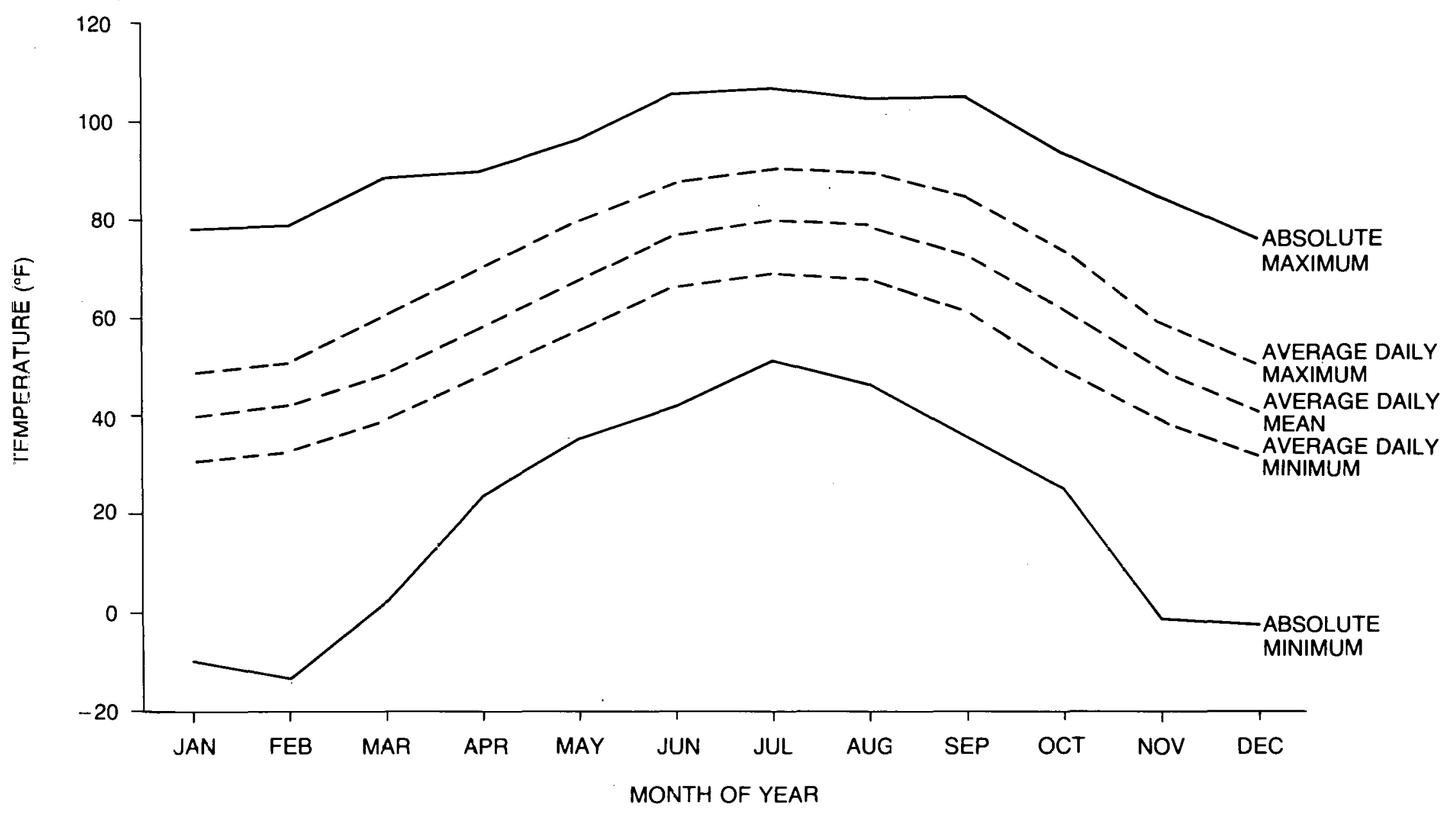

FIGURE IX-5 


\section{CHATTANOOGA ANNUAL TEMPERATURE DISTRIBUTION}

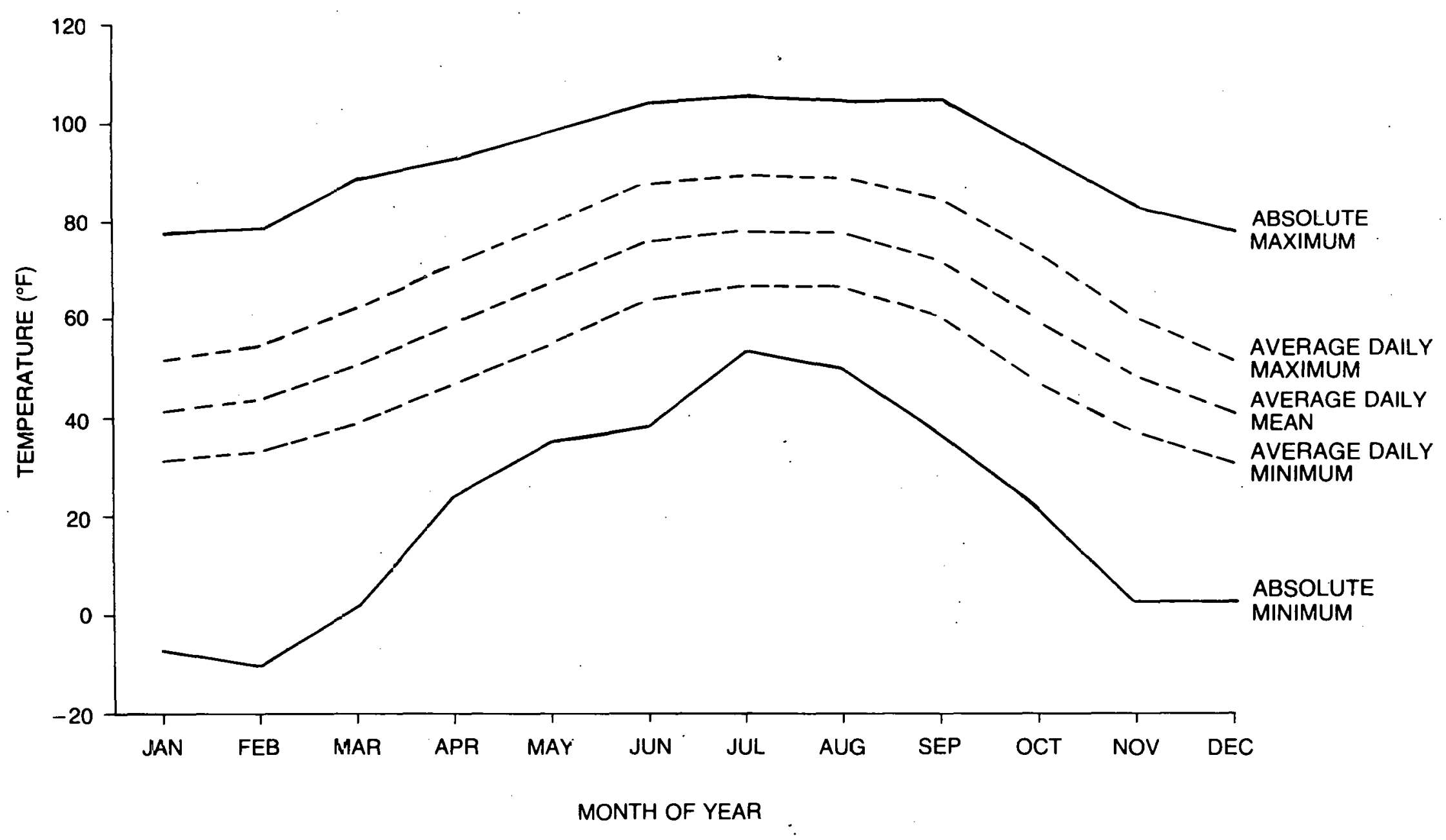

FIGURE IX-6 
isolated from the network shown in Figure IX-7. Not all data from the 126 stations in the four states have been included for analysis since precipitation tends to experience more drought/surplus cycles so that stations without comparable time-period records should not be compared. Data from 78 stations with concurrent precipitation histories exceeding 15 consecutive years have been used to construct the average annual precipitation map appearing in Figure IX-8.

Since the principal source of moisture for precipitation is from the Gulf of Mexico, there is a steady gradation of average precipitation amounts from south to north. However, the moisture supply factor, as with temperatures, is strongly obscured by the overriding effects of topography. Since air cools by expansion as it rises and since the ability of the air to hold moisure is strongly temperature-dependent, average precipitation is generally higher at elevated locations.

Figure IX-8 shows that the rainfall totals vary from 48 inches in Kentucky to about 56 inches in Alabama, but the greatest variability is seen between stations on and off the Cumberland Plateau. Not only does the higher terrain intercept more moisture, but it also screens out the Great Valley area from receiving its full potential precipitation. The partial "rainshadow" created in the valley is rapidly reversed in the Great Smoky Mountains where up to 80 inches per year may fall on the highest slopes with a westerly exposure.

Precipitation is distributed throughout the year within two distinct synoptic regimes. The greatest precipitation occurs in winter and early spring when large-scale storms passing through the area display maximum intensity. The rainy period extends from December through March and typically accounts for 40-50 percent of the annual rainfall. A secondary maximum occurs in mid-summer when showers and thunderstorms yield occasional but heavy rainfall. Late spring typically encounters lighter rains, but the real "dry" period usually occurs in late September-October when rainfall amounts drop to less than 2 inches per month at many stations. As the slow-moving high pressure centers drift across the state under clear but hazy skies, a few dry spells of a week or more may persist, but there is hardly a station in the study area that has not experienced at least some measurable precipitation during every month of every year. 


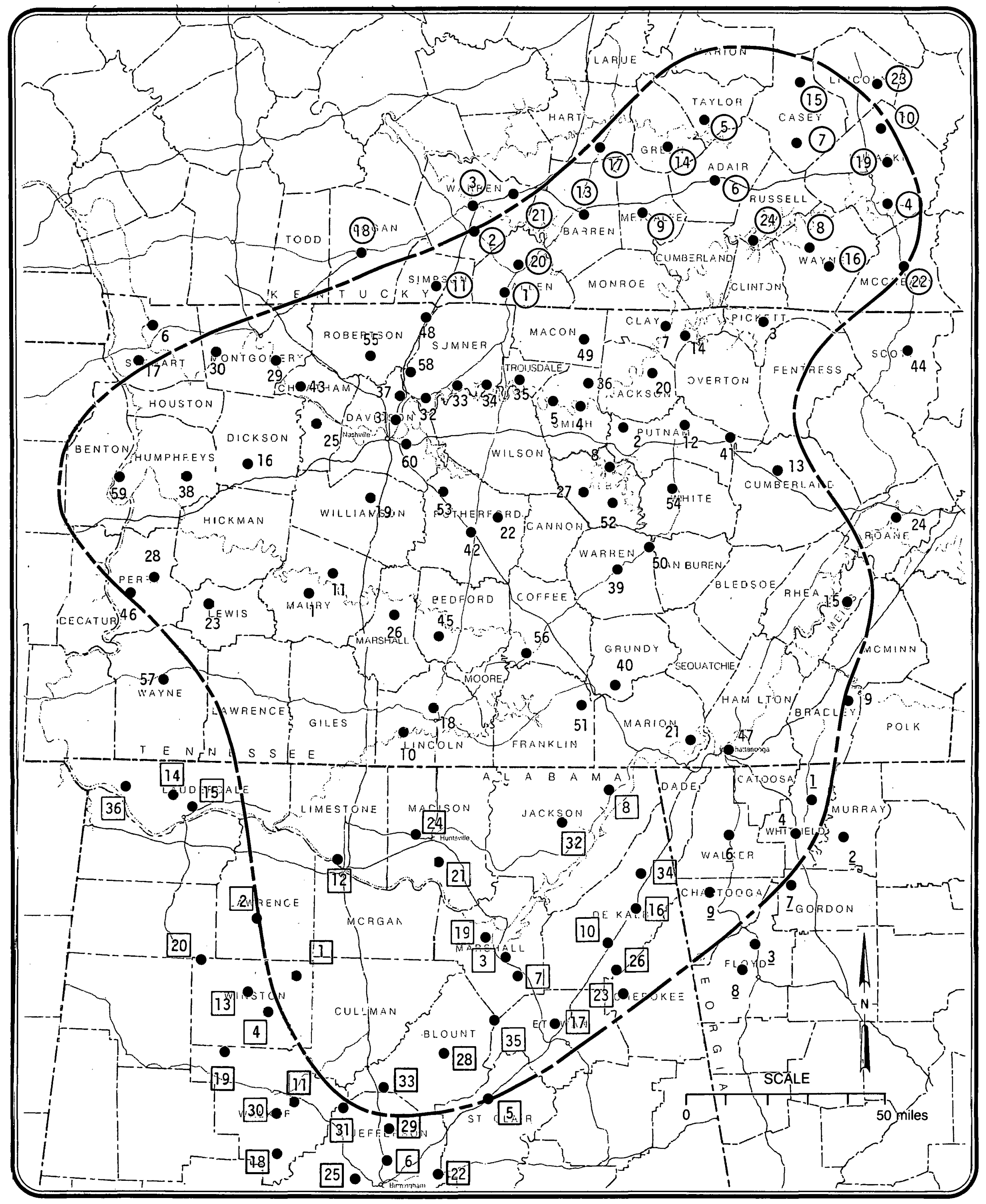

PRECIPITATION DATA SOURCES IN THE REGIONAL STUDY AREA
(refer to Appendix C for station identification)

KEY

- Climatic Station Location

73 Station Identifier - Tennessee

(11) Station Identifier - Kentucky

85 Station Identifier - Alabama

$\stackrel{2}{ }$ Station Identifier - Georgia

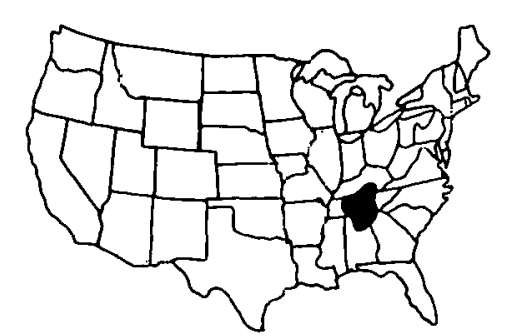






AVERAGE ANNUAL PRECIPITATION IN THE REGIONAL STUDY AREA

KEY

54 Precipitation (inches)

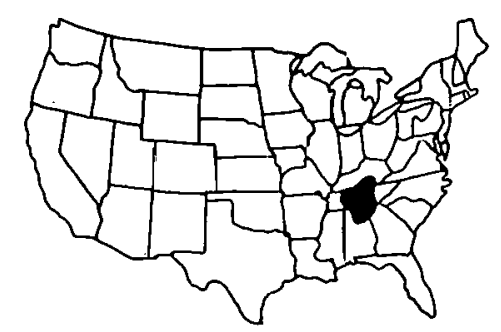


Figure IX-9 illustrates the monthly precipitation frequency distribution over the study area. Except for minor differences in the monthly and annual totals, the pattern of the winter maximum, summertime small relative maximum, and fall minimum is repeated throughout the entire area.

Although perhaps 98 percent of all precipitation falls as rain over the study area, the cold air from the northwest and the Gulf moisture supply often combine to cause snowfall. However, the relatively warm winter temperatures rarely allow the snowfall to persist for more than a few days, particularly in the lower elevations of the Tennessee and Cumberland River drainages. Total annual snowfall amounts vary from 1-2 inches in the southern portions of the region to more than 12 inches at some Kentucky and Cumberland Plateau stations. Figure IX-10 shows that in addition to the effects of elevated terrain, cold air pooled along the Cumberland and Barren River drainages further contributes to a "tongue" of heavier snowfall amounts stretching. from north central Tennessee into Allen and Barren Counties in Kentucky.

WINDS

The structure of the windfield, in conjunction with the vertical dispersive, capacity of the atmosphere, is the governing parameter defining regional pollution potential. To some extent, the horizontal winds even control the vertical turbulence field through the generation of mechanical turbulence as the flow passes over uneven terrain. Characterization of the windfield is thus very important in developing an environmental baseline for later examination of pollution dispersal.

Wind data are available from a number of agencies in the study area, but only a limited number have been used to categorize several quasi-homogeneous domains in the study area. Table IX-1 summarizes the stations that have been integrated into the regional airflow assessment. Although additional stations could have been included, data from these stations serve to point out the important features of the advection (horizontal motion) field of the atmosphere. 


\section{MONTHLY PRECIPITATION FREQUENCY DISTRIBUTION IN THE REGIONAL STUDY AREA}

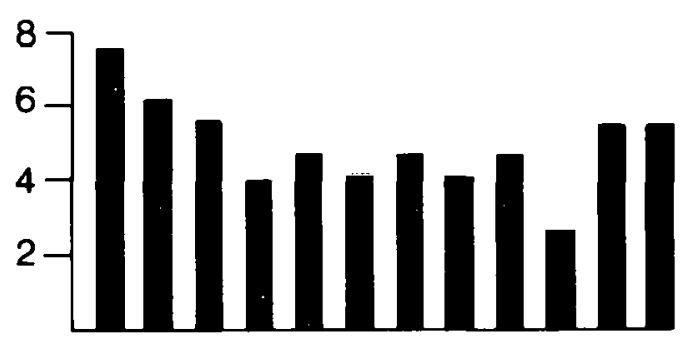

CENTER HILL DAM

DEKALB COUNTY, TENN.

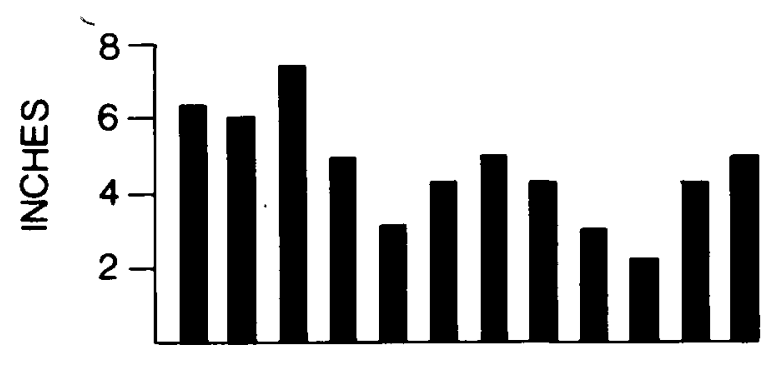

ONEONTA

BLOUNT COUNTY, ALA.

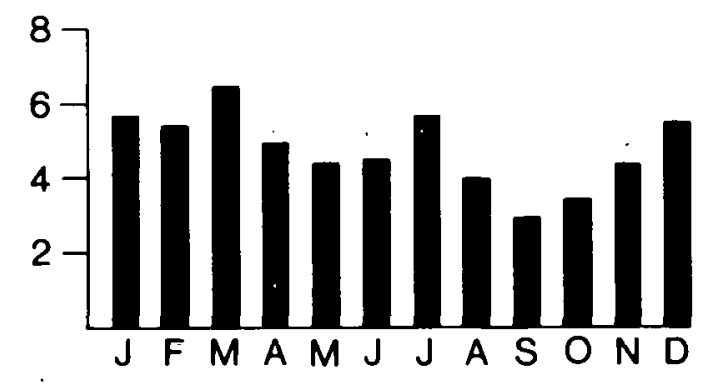

CHATTANOOGA (LOVELL FIELD) HAMILTON COUNTY, TENN.

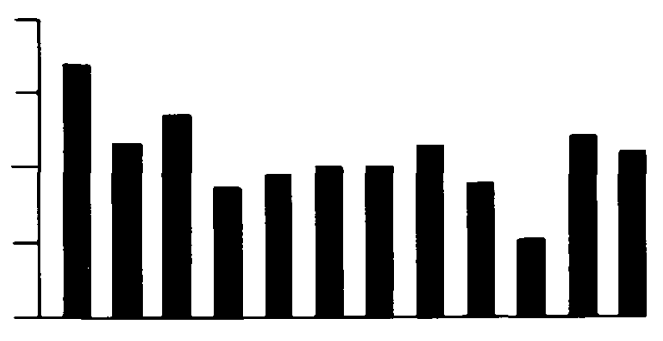

ADOLPHUS

ALLEN COUNTY, KY.

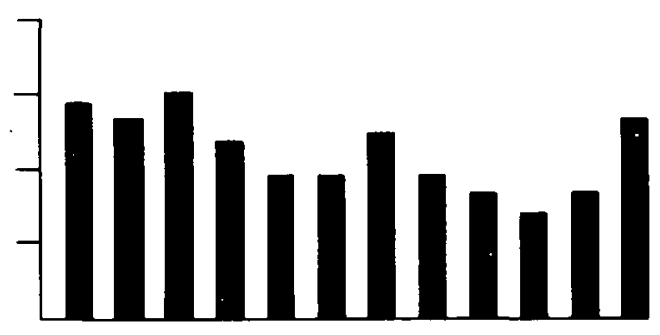

ROME (RUSSELL FIELD)

FLOYD COUNTY, GA.

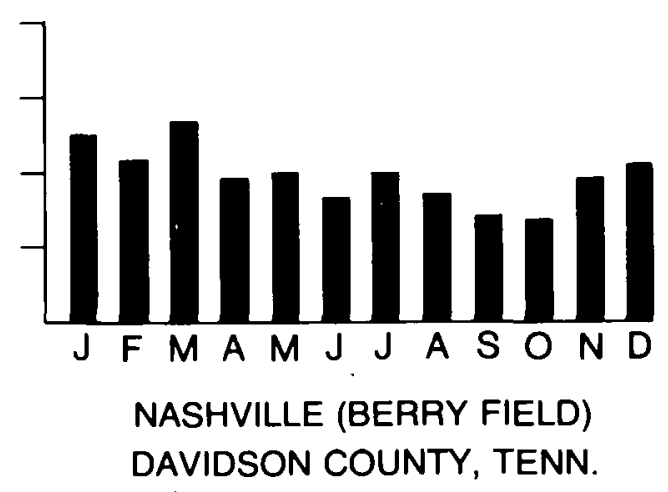

FIGURE IX-9 


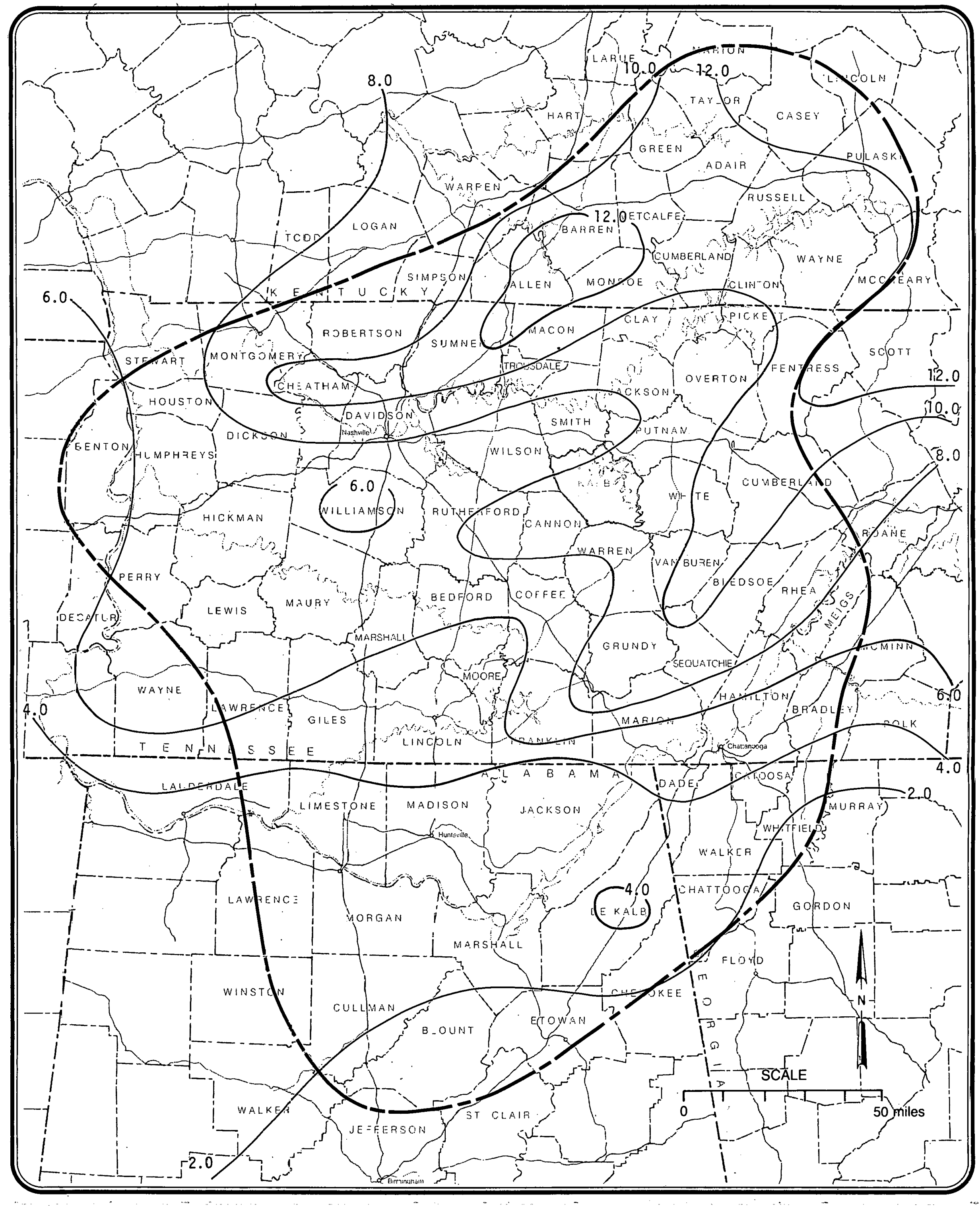

MEAN ANNUAL SNOWFALL IN THE REGIONAL STUDY AREA

$\underline{\mathrm{KEY}}$

8.0 Snowfall (inches)

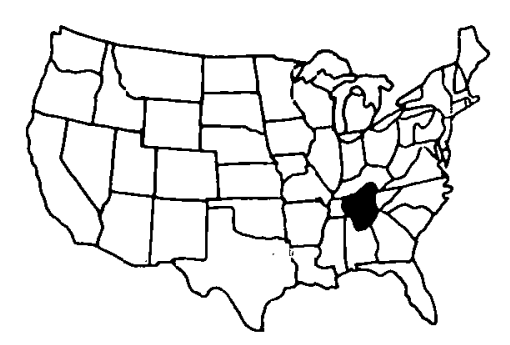


TABLE IX-1. WIND DATA SOURCES IN THE REGIONAL STUDY AREA

\begin{tabular}{llc}
\hline \multicolumn{1}{c}{ Station : } & Operating Agency & Period of Record Used \\
\hline Atlanta, Georgia & U.S. Weather Bureau & 10 years \\
Macon, Georgia & U.S. Weather Bureau & 10 years \\
Birmingham, Alabama & U.S. Weather Bureau & 10 years \\
Meruphis, Tennessee & U.S. Weather Bureau & 10 years \\
Chattanooga, Tennessee & U.S. Weather Bureau & 10 years \\
Nashville, Tennessee & U.S. Weather Bureau & 10 years \\
Knoxville, Tennessee & U.S. Weather Bureau & 10 years \\
Smithville, Tennessee & U.S. Weather Bureau & 5 years \\
Louisville, Kentucky & U.S. Weather Bureau & 10 years \\
Lexington, Kentucky & U.S. Weather Bureau & 5 years \\
Clinch River, Tennessee & Oak Ridge & i year \\
Watts Bar, Tennessee & T.V.A. & 1 year \\
Bellefonte, Alabama & T.V.A. & 1 year \\
\hline
\end{tabular}


Regional airflow is characterized by good ventilation and variety in wind direction in relatively unobstructed areas. Approaching the Cumberland Plateau, the wind direction distribution becomes distinctly bimodal as the prevailing winds line up more and more with the terrain. West of the plateau, the dominant wind directions are predominantly north-south. Across the plateau in the river valley the winds are strongly channeled. and considerably reduced in speed by the sheltering effect of the ridges and the higher mountains to the east. The terrain effect gradually diminishes with distance from the complex terrain near the river and the Smokies, such that Atlanta shows only minor terrain-induced motion and. almost no preferred wind directions are exhibited further into Georgia.

The annual directional distribution of wind (wind roses) for the regional stations is presented in Appendix C, grouped according to the degree of channeled motion, viz., Tennessee River Valley (Knoxville, Oak Ridge, Watts Bar, Chattanooga, Bellefonte), Plateau western foothills (Birmingham, Smithville and Lexington), Mississippi/Ohio River Valley (Memphis, Louisville), eastern foothills (Atlanta) and no noticeable terrain effects (Nashville and Macon).

The diversity in wind directions is also reflected in a similar diversity in wind spceds. Average wind specds over the study area are about 7-10 mph which is indicative of excellent pollution dispersal. Seasonal and diurnal cycles cause considerable oscillation about the average, but the unobstructed areas of the region have good ventilation and dispersal characteristics. In the more sheltered environments, however, wind speeds decrease dramatically. In areas where the valley of the Tennessee River is wide or the terrain relatively flat, only moderate reduction in wind speed is noted. In confined areas near the system of parallel ridges along the valley, the reduction in wind speed and the potential for low-level pollutant dispersal is much more strongly affected by the terrain influence. Average wind speeds vary from about $10 \mathrm{mph}$ at stations such as Memphis, Atlanta, and Lexington, and drop to a low of only about $3 \mathrm{mph}$ at the Clinch River Breeder Reactor site at Oak Ridge. 
Wind speeds throughout the year undergo seasonal variations that are fairly uniform over much of the area. Maximum surface wind speeds are usually found in March with a minimum in August. Speeds in spring are 20-30 percent above the annual average and mid to late summer speeds are a similar percentage below average.

Directional changes in seasonal wind distributions are very subtle and do not generally equal in degree the seasonal speed variations. Seasonal wind roses for the regional U. S. Weather Bureau stations across the study area, presented in Appendix C, reveal only minor seasonal differences. The presence of the sub-tropical high in summer creates a flow from the northeast across Georgia and Alabama, but areas protected by the Smokies do not show such monsoon circulation effects. Slight shifts in the prevailing directions and some strengthening of the synoptic gradient westerly components are noted in winter, but the seasonal oscillations in the directional frequency distribution are of small amplitude over most of the area.

The foregoing discussion points out that, despite the apparent complexity of the regional flowfield, one can infer the wind characteristics of a given area with some degree of confidence. By analyzing the degree of interaction between the flow and the local terrain, both the prevailing directions and average speeds can be derived.

STORMS

Assessing the influence of weather upon man and industrial development warrants consideration of the probability of severe weather and its implications with respect to engineering design. Again; topography plays a very important role in varying the regional distribution of severe weather phenomena. Typically, however, damaging storms are of such large scale that they can be well described by their regional characteristics. Fortunately, the study region is south of the major blizzards, too far inland for the full force of hurricanes, and east of the belt of heaviest tornadoes. Although the area certainly experiences Its fair share of destructive wcather, there are a number of worse geographical regions. 
Thunderstorms and Hail

Thunderstorms are a frequent occurrence in the southwestern United States as the cold air from the north encounters the warm and moist air from the Gulf of Mexico. They occur both with squall lines and the passage of active cold fronts. Although usually not as damaging as the thunderstorms on the Great Plains, thunderstorm activity in Kentucky, Tennessee, Alabama, and Georgia may cause damage due to high winds and hail.

Thunderstorms occur in the study area 45 to 60 days per year. Frequencies in Kentucky and portions of the Great Valley are relatively low and increase further south, expecially around Chattanooga and into Alabama. Table IX-2 summarizes the area thunderstorm frequency. As expected, summers from June to August show a maximum with a corresponding minimum in the winter months from November through January. As discussed later, the frequency is not necessarily an indicator of severity; thus springtime thunderstorms are often much more severe than their summer counterparts.

In the southeastern United States, hail is not as common nor as large as in the midwestern states. The number of hailstorms increases from south to north with two hailstorms per year in Alabama and Georgia, increasing to about four occurrences per year across Tennessee and into Kentucky. Hailstones are usually small with crop damage less by a factor of ten than in a more severe hailstorm state such as Kansas.

Blizzards and Glaze Storms

Winter storms that might be classified as blizzards are uncommon in the area. Snowfalls in excess of 1 inch per year occur less than once per year in north-central Alabama and increase to 4-5 per year in Kentucky and on the Cumberland Plateau. Tremendous snowfalls have been recorded a few times in the history of some of the long-period monitoring stations, particularly early in the "winter" season in November and late in the season in March. Knoxville recorded 18.2 inches of snow in November, 1952, in one 24-hour period. Memphis received 18.0 inches and Nashville 17.0 inches during a storm in March, 1892, during one 24-hour period. 
TABLE IX-2. MONTHLY AND ANNUAL THUNDERSTORM FREQUENCY IN THE REGIONAL STUDY AREA

\begin{tabular}{lcccccccccccccc}
\hline & \multicolumn{1}{c}{} & J & F & M & A & M & J & J & A & S & 0 & N & D & Annual \\
\hline Louisville, Kentucky & 1 & 1 & 3 & 4 & 6 & 9 & 8 & 7 & 4 & 2 & 1 & - & & 46 \\
Lexington, Kentucky & 1 & 1 & 3 & 4 & 6 & 9 & 9 & 7 & 4 & 1 & 1 & 1 & 47 \\
Knoxville, Tennessee & - & 1 & 3 & 4 & 6 & 9 & 10 & 8 & 4 & 1 & 1 & - & 47 \\
Atlanta, Georgia & 1 & 2 & 4 & 5 & 6 & 9 & 11 & 8 & 3 & 1 & 1 & 1 & 50 \\
Memphis, Tennessee & 2 & 2 & 4 & 5 & 6 & 8 & 8 & 7 & 3 & 2 & 2 & 1 & 50 \\
Nashville, Tennessee & 1 & 2 & 4 & 5 & 7 & 9 & 10 & 7 & 4 & 1 & 1 & 1 & 52 \\
Oak Ridge, Tennessee & 1 & 2 & 3 & 5 & 8 & 9 & 11 & 9 & 3 & 1 & 1 & 1 & 54 \\
Birmingham, Alabama & 2 & 3 & 5 & 5 & 7 & 9 & 11 & 9 & 4 & 1 & 2 & 1 & 58 \\
Chattanooga, Tennessee & 1 & 2 & 4 & 5 & 8 & 11 & 12 & 10 & 4 & 1 & 1 & - & 59 \\
Huntsville, Alabama & 2 & 3 & 5 & 5 & 7 & 9 & 11 & 8 & 5 & 2 & 2 & 1 & 59 \\
Rome, Georgia & 2 & 2 & 4 & 5 & 7 & 10 & 13 & 10 & 4 & 2 & 2 & 1 & 61 \\
\hline
\end{tabular}


Glaze (ice storms) forms when freezing rain from a warm layer of clouds descends through a very shallow layer of cold air. When the liquid drops strike a cold object the drops freeze immediately and form a sheet of ice. Freezing rain occurs about once per year in Alabama and increases to perhaps four times per year in the northern portion of the study area. Heavy ice deposits ( $>0.25$ inch) occur once every two years in east-central Tennessee with deposits in excess of 0.50 inches occurring once every 5 years. Ice storms that cripple traffic and cause significant damages may occur once in perhaps 10 years.

\section{Strong Winds}

High winds, without tornadoes, are usually associated with thunderstorm air outflow during extremely strong storms. Since such high winds are the result of downrush and the motion of the storm itself, many of the high wind occurrences arrive from a westerly direction. Differences in recording-period durations make direct comparison of maximum observed winds difficult. Using the available length of record and extreme value probability charts, an estimate similar to the 100-year flood concept can be developed for wind speed. Based on fastest-mile reported wind speeds at Knoxville and Nashville of 73 miles per hour, and a fastest mile. speed of 82 miles per hour at Chattanooga, an estimated 100-year maximum of 89 miles per hour for the study area has been calculated.

Hurricanes are rare in the area because they diminish rapidly in intensity when cut off from their moisture supply. Although remnants of systems may cause some flooding due to torrential rains, wind effects from tropical storms are minimal at distances of a few hundred miles inland.

\section{Tornadoes}

Although the area from Kentucky to northern Alabama and Georgia does "not experience tornadoes in high frequency, these storms represent the greatest threat to 1 ife and property of all the severe weather phenomena. Axial winds in excess of $200 \mathrm{mph}$ are often found at the wall of the 
funnel, with winds of $300 \mathrm{mph}$ not impossible. While the tornado path is usually only several hundred yards wide and a few miles long, its destructive potential from rapid winds and flying debris extends over a much wider area.

Tornado frequencies in the United States have been tabulated by a number of agencies; their frequency per unit area is shown in Figure IX-11 for a 5-year period extending from 1960 to 1964. Compared to the states further west, the area beween the Mississippi/Ohio Rivers and the Appalachians is seen to be an area of far fewer tornadoes than the maximum number occurring in the Oklahoma and Kansas area. The typical tornado frequency is two storms per $10,000 \mathrm{mi}^{2}$ per year across central Tennessee. Values are slightly lower for Kentucky and slightly higher for Alabama: Assuming a tornado swath 250 yards wide by 5 miles long, the probability that a tornado will strike a particular point is calculated as $1.41 \times 10^{-4}$ per year. The recurrence interval, i.e., the inverse probability, is once in 7,040 years for any point in central Tennessee. Although there is a definite gradient of tornado increases from the eastern portion of the study area toward the. west such that the western half of Tennessee experiences almost three times as many tornadoes as the eastern half, further resolution of the point frequency and recurrence interval (return period) is difficult to predict.

\section{ATMOSPHERIC STABILITY AND INVERSIONS}

The thermal structure of the atmosphere controls the depth through which pollutants emitted within any layer of the atmosphere can be mixed. Large turbulent eddies are associated with rapid and deep dispersion, small eddies lead to very slow dispersion rates. When temperature increases with height (a temperature inversion), vertical dispersion becomes severely restricted. This stability is due to the expansion and cooling of riging air from close to the surface. As polluted air rises into a lower pressure environment it expands due to pressure differences. If the ambient atmosphere is considerably warmer than any rising "bubbles" of air, a strong restoring force acts on any convective motion to completely 


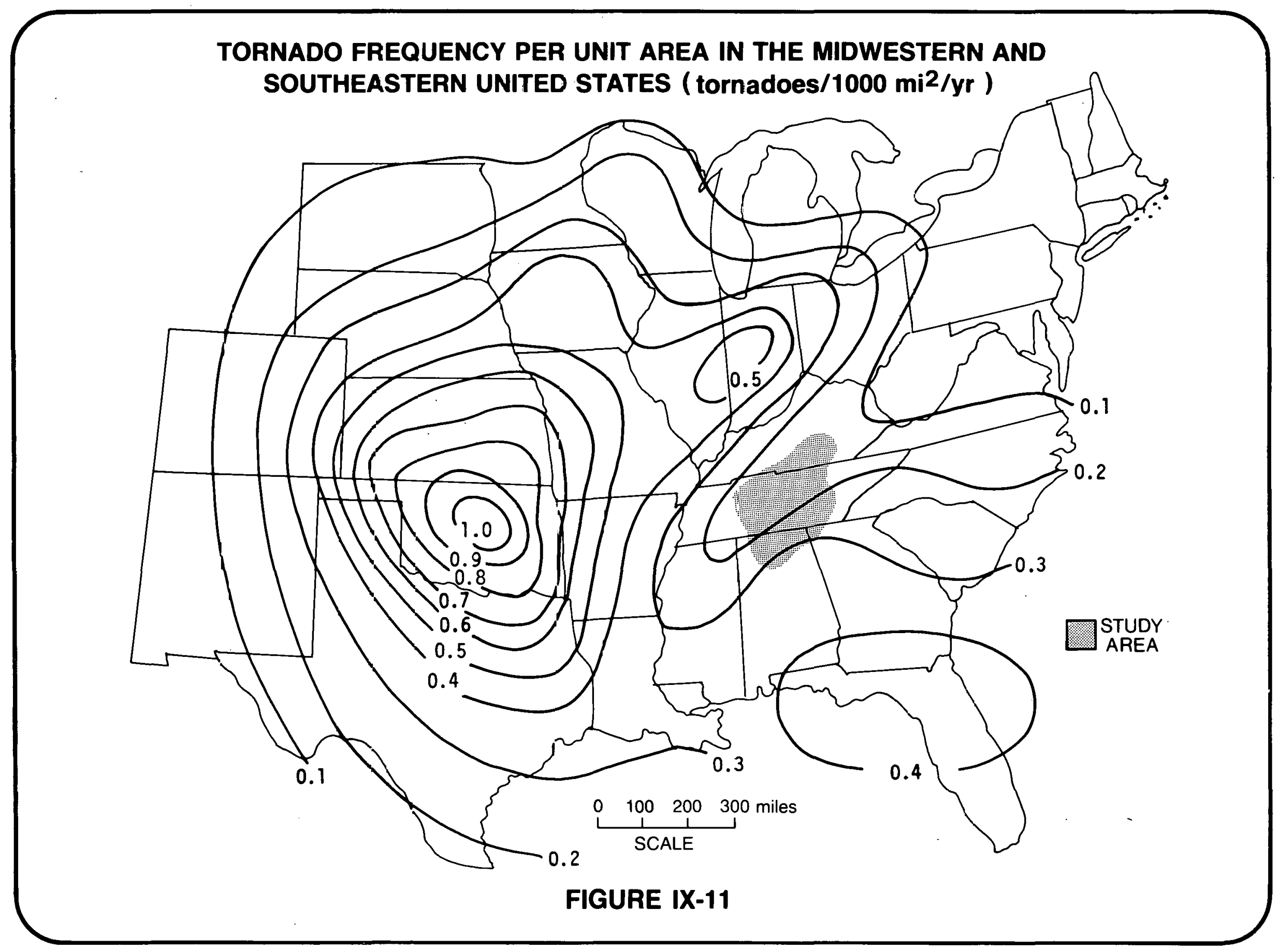


suppress the vertical redistribution of pollutants. If the temperature inversion is ground-based, it confines all low-level pollutants within a shallow layer. If the temperature inversion is situated aloft, it traps the polluted air in a shallow layer beneath the inversion that leads to a rapid accumulation of pollution concentrations.

Inversion frequencies have been compiled throughout the region comprising the Chattanooga Shale resource as an indicator of the potential for regional pollutant build-up. Regional inversion statistics, based upon the total number of hours per year of a temperature inversion below 500 feet, show the following totals:

$\begin{array}{ll}\text { Winter } & 910 \text { hours } \\ \text { Spring } & 707 \text { hours } \\ \text { Summer } & 994 \text { hours } \\ \text { Fall } & 983 \text { hours }\end{array}$

Annual $\quad 3,594$ hours .

The frequency of low-level inversions is dominated by anticyclonic conditions that lead to subsiding air aloft and fair skies, allowing strong radiational cooling. Included in the annual inversion frequency of 45 percent are both the "elevated subsidence" inversion as well as the more predominant "radiation" inversion.

Rather than defining the limits of the temperature structure, the mean mixing depth (layer through which vigorous vertical mixing can occur) is perhaps a more instructive description of vertical dispersive capability. Based upon the data derived from the twice-daily Nashville radiosonde sounding, Holzworth [1972] has derived seasonal and annual mixing heights (depths) that are typically representative over much of the study area except on the fringe of the area along the Cumberland Plateau. As seen in Table IX-3, Holzworth's data show that the generally fair weather of many fall mornings is also associated with the lowest well-mixed layer, and therefore is conducive to high pollution potential. By mid-afternoon the mixing usually exceeds $1 \mathrm{ku}$, even on colder winter days. Summer 
TABLE IX-3. REGIONAL MIXING DEPTHS OVER THE STUDY AREA

\begin{tabular}{|c|c|c|c|}
\hline \multirow[b]{2}{*}{ Season } & & \multicolumn{2}{|c|}{ Mixing Depth } \\
\hline & & $\begin{array}{l}\text { Morning } \\
\text { (meters) }\end{array}$ & $\begin{array}{r}\text { Afternoon } \\
\text { (meters) }\end{array}$ \\
\hline Winter & & 563 & 1,123 \\
\hline Spring & $\cdot$ & 606 & 1,783 \\
\hline Summer & & 441 & 1,874 \\
\hline Fall & & 357 & 1,473 \\
\hline Annual & & .492 & 1,563 \\
\hline
\end{tabular}


afternoons offer the best vertically mixed environment with few air quality problems persisting through the vigorous vertical mixing of convectively driven circulation cells.

By combining the mixing height, $H$, with the mean advective speed, $\bar{U}, a$ three-dimensional ventilation index of $\mathrm{HxU}$ can be defined to correlate the simultaneous occurrence of horizontal and vertical advection phenomena. Holzworth [1972] has also tabulated the number of days of protracted overall poor ventilation stratified according to various $H$ and $\bar{U}$ increments. Table IX-4 indicates that the most restrictive ventilation index noted in 5 years of data was $2,000 \mathrm{~m}^{2} / \mathrm{sec}(4 \mathrm{~m} / \mathrm{sec} \times 500 \mathrm{~m})$ which occurred for one 2-day period in winter. Similarly, three episodes of a maximum index of $3,000 \mathrm{~m}^{2} / \mathrm{sec}$ (one $6 \mathrm{~m} / \mathrm{sec} \times 500 \mathrm{~m}$, two $2 \mathrm{~m} / \mathrm{sec} \times 1,500 \mathrm{~m}$ ) were noted in a 5-year period. By comparison, in the poorer dispersion climate of California, an index of $3,000 \mathrm{~m}^{2} / \mathrm{sec}$ or less was experienced on 326 days in San Diego, 261 days in Santa Monica, and 168 days in Oakland during the same time period.

Using an index of $6,000 \mathrm{~m}^{2} / \mathrm{sec}$ derived from a combination of $4 \mathrm{~m} / \mathrm{sec}$ of wind and a mixing height of $1,500 \mathrm{~m}$, the number of days of high air pollution potential have been calculated for the entire United States over the same 5-year period as above. The compilation of Holzworth [1972] in Figure IX-12 shows that the study area encompasses some of the areas of higher potential stagnation in the eastern portion of the country. To be sure, values in the Great Valley and into the Smokies are higher than in south-central Kentucky, central Tennessee, and northern Alabama, neverthelcas the ventilation-limiting effects of low winds and low mixing heights due to the Bermuda High are readily apparent. Thirty days of poor ventilation (about 6 days per year) appears to be a representative value over the area of interest. Except for these few stagnation conditions that usually occur in the fall, indications are that dispersion of shale resource development emissions should be very good, particularly in any areas west of the Cumberland Plateau. 
TABLE IX-4. REGIONAL STUDY AREA VENTILATION INDEX BREAKDOWN FOR 2- AND 5-DAY RESTRICTED VENTILATION EPISODES (1960-1964)

\begin{tabular}{|c|c|c|c|c|}
\hline \multicolumn{5}{|c|}{ 2-Day Episodes } \\
\hline $\begin{array}{l}\text { Wind } \\
\text { Speed } \\
\text { (m/sec) }\end{array}$ & 500 & $\begin{array}{r}\text { xing } D \\
1,000\end{array}$ & 1,500 & 2,000 \\
\hline 2 & $0 / 0$ & $0 / 0$ & $2 / 4$ & $3 / 6$ \\
\hline 4 & $1 / 2$ & $5 / 13$ & $17 / 40$ & $\begin{array}{c}44 / 109 \\
F\end{array}$ \\
\hline 6 & $1 / 3$ & $\begin{array}{c}12 / 34 \\
W\end{array}$ & $\begin{array}{c}48 / 126 \\
F\end{array}$ & $\underset{\mathrm{F}}{107 / 314}$ \\
\hline \multicolumn{5}{|c|}{ 5-Day Episodes } \\
\hline Wind & \multirow{2}{*}{\multicolumn{4}{|c|}{$\begin{array}{l}\text { Mixing Depth (m) } \\
1,000\end{array}$}} \\
\hline $\begin{array}{l}\text { Speed } \\
(\mathrm{m} / \mathrm{sec})\end{array}$ & & & & \\
\hline 4 & $0 / 0$ & $0 / 0$ & $0 / 0$ & $2 / 10$ \\
\hline 6 & $0 / 0$ & $0 / 0$ & $0 / 0$ & $\underset{W}{9 / 51}$ \\
\hline
\end{tabular}

KEY: Number of episodes/total days in those episodes Season of maximum episode occurrence 
TOTAL NUMBER OF FORECAST DAYS OF HIGH METEOROLOGICAL POTENTIAL FOR HIGH AIR POLLUTION IN A 5-YEAR PERIOD THROUGHOUT THE UNITED STATES

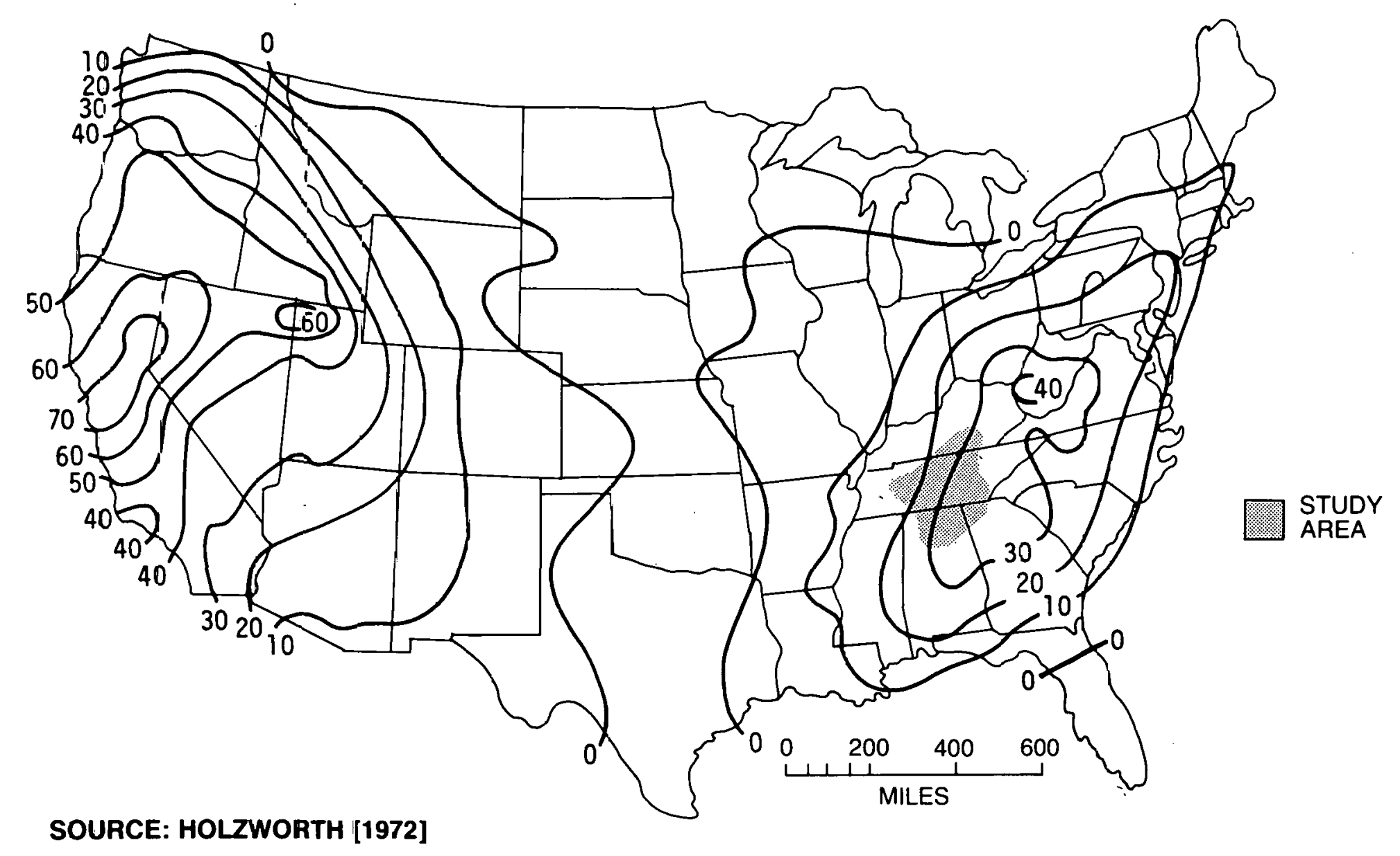

FIGURE IX-12 


\section{LOCAL CHARACTERIZATION}

DeKalb County is typical topographically of the areas along the Highland Rim, with rolling hills dropping sharply into the Caney Fork River and Smith Fork drainages. Topographic effects do not dominate the flowfield except along the bottoms of the many hollows and creeks, but the gradual rise of the Cumberland Plateau to the east does exert an overall steering mechanism on atmospheric motion. Terrain relief is not unimportant as evidenced by Short Mountain (elevation 2,092 feet) to the west of the county and Green Spring Mountain to the east (elevation 1,673 feet); nevertheless, the climatic characteristics of the county are not indicative of what would be considered extremely complex terrain.

\section{TEMPERATURE}

The temperature distribution in DeKalb County is very similar to the Tennessee statewide average indicating that its relative position in central Tennessee creates a median climate. The statewide average temperature is $58.8^{\circ} \mathrm{F}$, with average summer and winter temperatures of $76.4^{\circ} \mathrm{F}$ and $40.4^{\circ} \mathrm{F}$, respectively. Eight years of data from the Smithville Airport in DeKalb County give almost identical values for annual mean - $58.1^{\circ} \mathrm{F}$, summer average (July) - $76.4^{\circ} \mathrm{F}$, and winter average (January) - $40.6^{\circ} \mathrm{F}$. "Tennessee Community Data", prepared in 1976 by the State Division of Industrial. Development, reports values of $59^{\circ}$, $77^{\circ}$, and $42^{\circ} \mathrm{F}$ for the same three reporting periods.

Monthly temperatures presented in Figure IX-13 show that the winters are given to much larger extremes than the summer months. Variations between absolute maxima and minima as great as $90^{\circ} \mathrm{F}$ may occur in winter, while summers show a much smaller range of about $60^{\circ} \mathrm{F}$ between absolute extremes. Winter minima may be as much as $40^{\circ} \mathrm{F}$ below the mean during. intense Arctic outbreaks; corresponding summer differences for both maxima and minima are much smaller. 


\section{ANNUAL TEMPERATURE DISTRIBUTION IN DEKALB COUNTY (SMITHVILLE AIRPORT)}

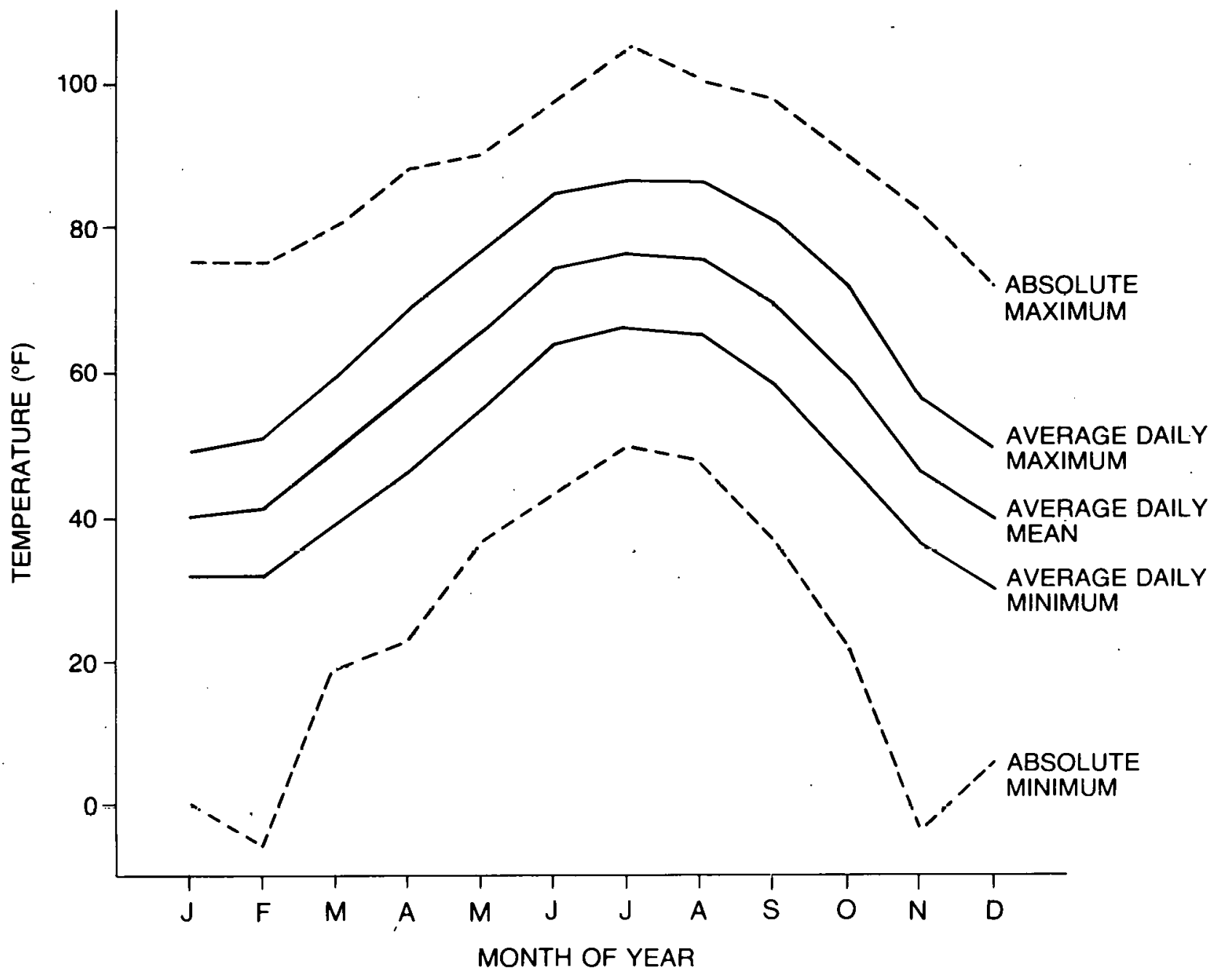

FIGURE IX-13 
Freezing temperatures usually begin in late 0ctober and the last frost normally occurs during the first two weeks of April. The mean number of frost-free days is about 200. The mean date of occurrence of extremely cold temperatures. (lower than $16^{\circ} \mathrm{F}$ ) is between mid-December to mid-February, with about 300 days per year free from such extremely cold conditions.

\section{$\underline{\text { PRECIPITATION }}$}

As is the case with temperature, DeKalb County experiences a mean annual rainfall very similar to the statewide average. About 98 percent of the approximately $50^{\circ}$ inches per year of precipitation falls as rain and the remainder in frozen forms. Records from three climatic reporting stations in the county are available with varying time periods of record. An excellent long-term record from Liberty covers approximately 50 years of observations. Shorter term measurements from Center Hill Dam and the Smithville Airport with similar mean rainfall amounts attest to a climatological homogeneity over the county. Annual average rainfall totals for the three stations are reported as follows: Liberty - 52.19 inches, Smithville - 53.26 inches, and Center Hill Dam - 54.62 inches.

The annual distribution of precipitation for the three locations shows a similar pattern in both the means and extremes. Monthly rainfall shows a slight dip in early spring and again in early fall as the principal precipitation mechanism changes from the synoptic-frontal systems of the winter to the convective thunderstorm weather of summer. Figure IX-14 illustrates the similarity of the precipitation profiles for the three observation sites. Maxima in January and isolated September maxima associated with tropical storms are interspersed between the two transitional minima. Differences in the three sets of traces are due in part to normal statistical variation caused by different sampling locations; however, the main cause of difference is a different sampling period for each site data base.

Maximum monthly rainfall in January has been as high as 16.64 inches in Smithville, and a June minimum of 0.03 inches was observed once in Liberty. Nlthough there may be a month with no precipitation in the 
MONTHLY PRECIPITATION FREQUENCY DISTRIBUTION IN DEKALB COUNTY

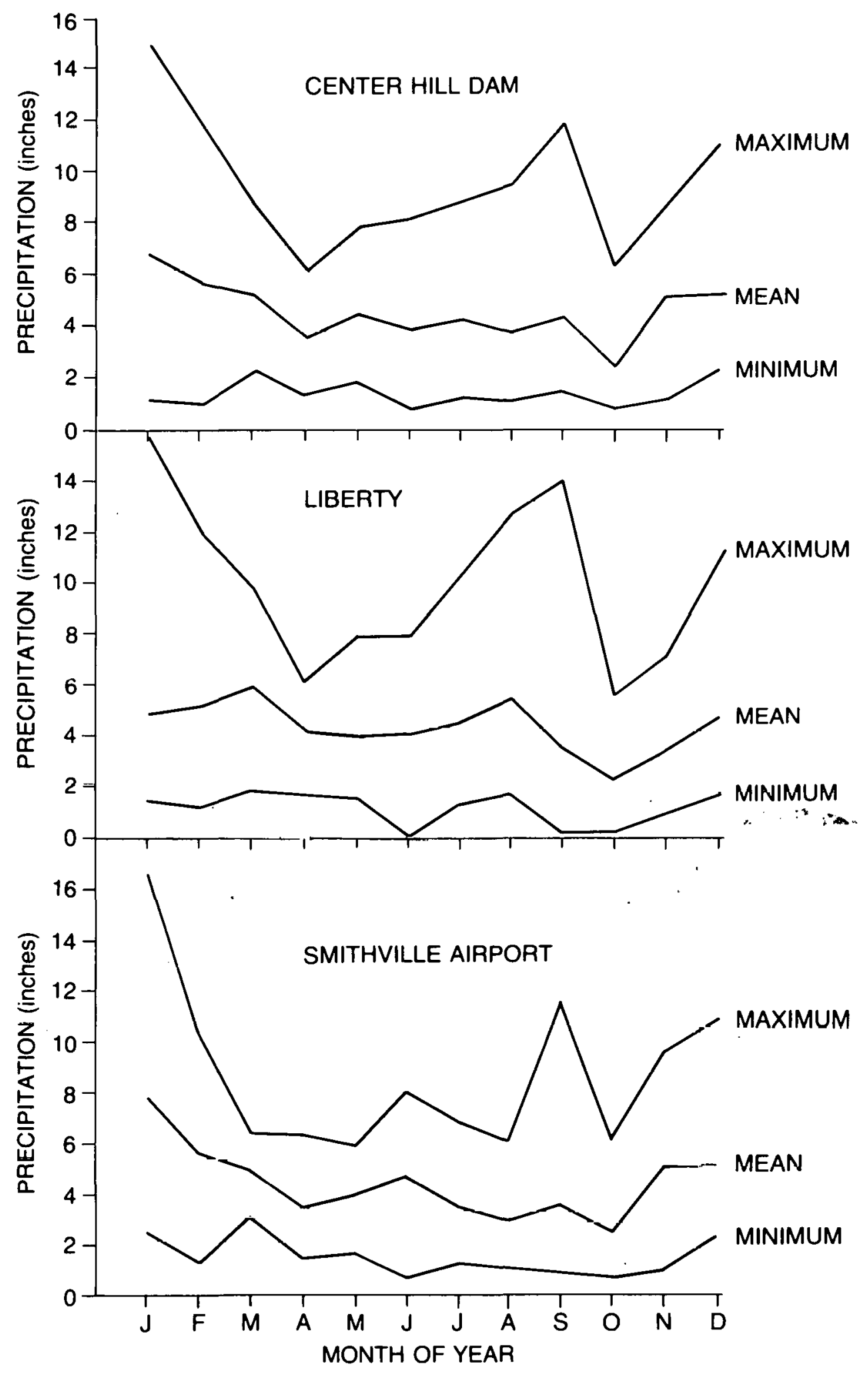

FIGURE IX-14 
long-period climatic record, such an occurrence is extremely rare in the county. Rainfall is equitably distributed in space and time in the area and contributes to a plentiful water resource.

\section{CLOUDS AND VISIBILITY}

Clouds and visibility are an important consideration in terms of driving and flying conditions in the local area. Visibility and flying weather data tabulated by the United States Weather Bureau for May, 1937 through December, 1941 for the Smithville Airport show that the combination of fog and restricted visibility due to precipitation reduced the prevailing visibility to 7 miles or less during over 25 percent of all winter observations. Summer, in contrast, is a time of generally very good flying conditions.

Figure IX-15 gives the visibility distribution derived from the 38,923 observations comprising the Smithville data set. In Figure IX-16, fog frequency is isolated from the other types of visibility obstructions. As shown, the critical parameter, dense fog, occurs a maximum of 15 hours per month in December with other winter months experiencing slightly fewer hours of fog-reduced visibility. A few occurrences of early: morning ground fog in summer also reduce visibility below safe levels, but these fogs typically burn off shortly after sunrise.

Ceiling heights indicated in Table IX-5 show that the low cloud distribution essentially follows the fog frequency, as the two conditions are often coupled. In slightly more than 2 percent of the winter observations, clouds are so low as to render flying operations extremely hazardous (about 15 hours per month, 44.6 hours for the winter season). Cloudiness decreases throughout the year until September when 86.2 percent of all observations are clear, partly cloudy, or the cloud cover is at or above 10,000 feet. Maximum cloudiness is registered in February when more than 50 percent of all observations register a ceiling below 10,000 feet: 


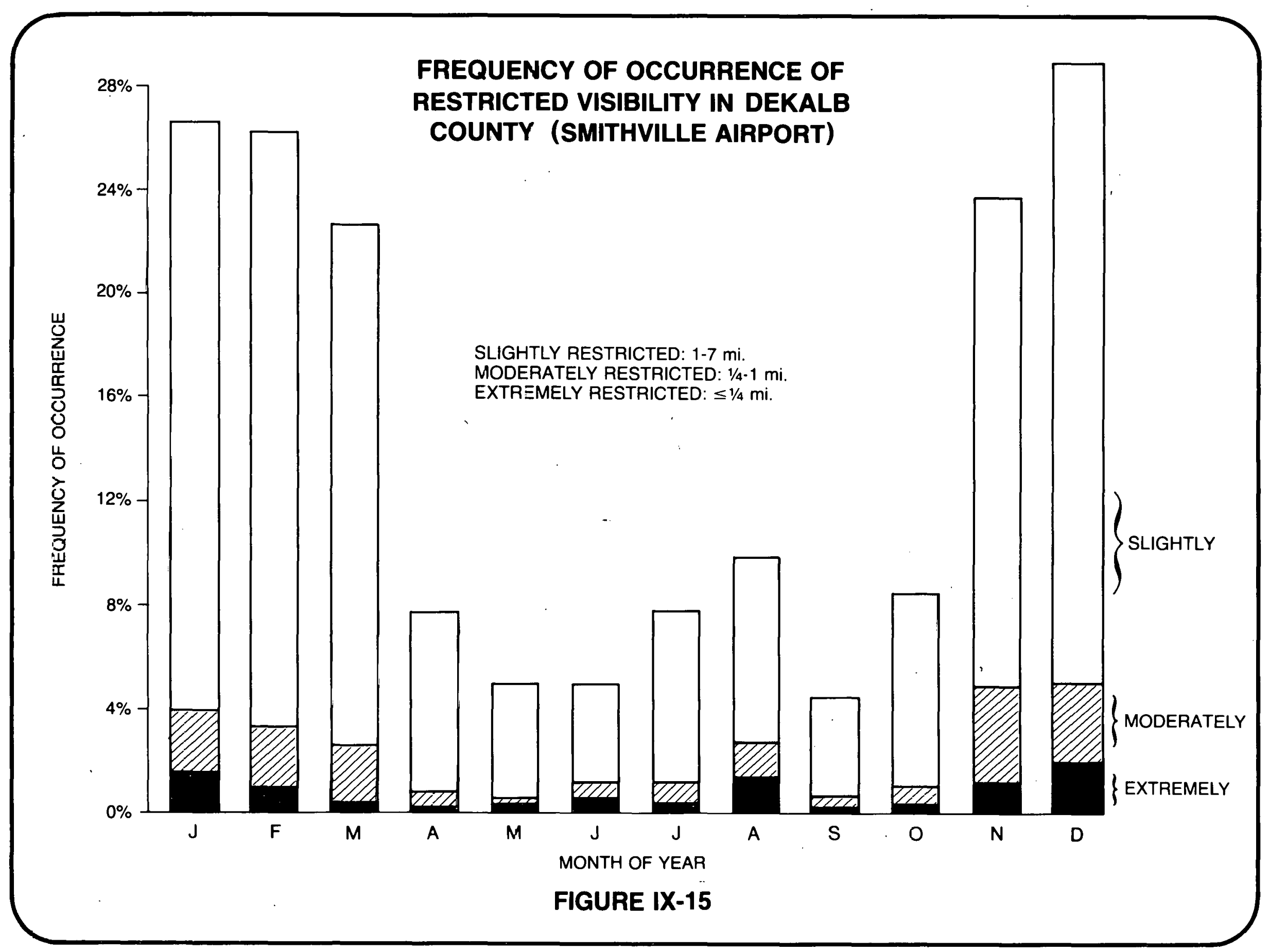




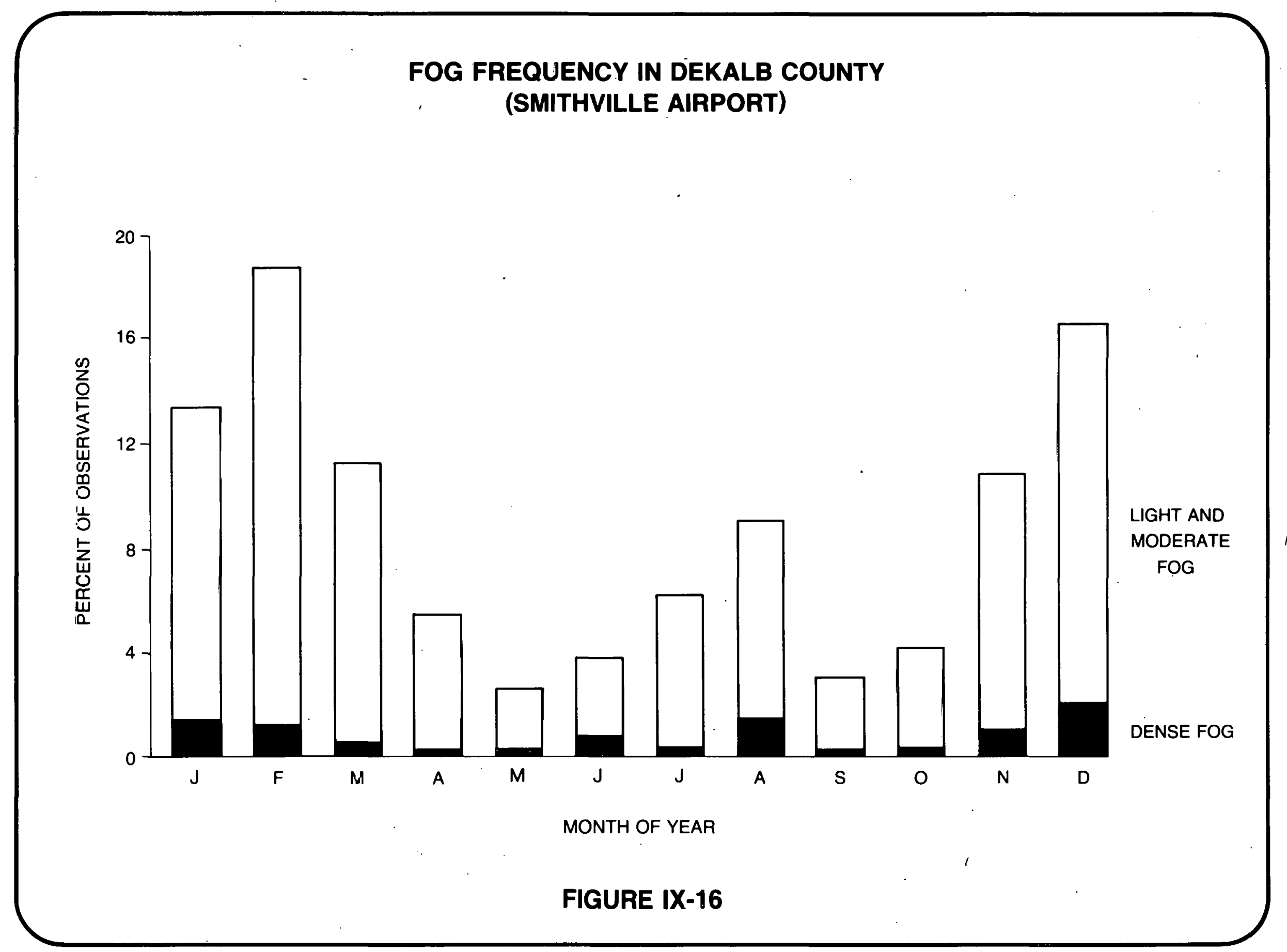


TABLE IX-5. CEILING HEIGHT FREQUENCY AT THE SMITHVILLE AIRPORT (1937-1941)

\begin{tabular}{lcccc}
\hline \multirow{2}{*}{ Month } & \multicolumn{4}{c}{ Ceiling Height (feet) } \\
\cline { 2 - 5 } January & 300 & $\leq 301-1,000$ & $\leq 1,001-10,000$ & $\geq 10,000$ \\
February & 1.6 & 9.1 & 34.7 & 54.6 \\
March & 2.3 & 14.4 & 33.9 & 49.4 \\
April & 1.1 & 7.7 & 33.4 & 57.8 \\
May & 0.5 & 4.3 & 30.4 & 64.8 \\
June & 0.0 & 2.0 & 23.7 & 74.3 \\
July & 0.3 & 2.5 & 20.9 & 76.3 \\
August & 0.3 & 2.0 & 19.7 & 78.0 \\
September & 0.6 & 2.3 & 17.1 & 80.0 \\
October & 0.3 & 1.9 & 11.6 & 86.2 \\
November & 0.3 & 2.9 & 15.6 & 81.2 \\
December & 1.4 & 5.9 & 26.9 & 65.8 \\
Annual & 2.3 & 9.7 & 32.4 & 55.6 \\
\hline Mean & 0.9 & 5.4 & 25.1 & 68.6 \\
\hline
\end{tabular}


WINDS

One of the unique characteristics of the windfield over DeKalb County is how little its directional distribution changes throughout the year. The lack of significant topographic relief near the airport site allows the winds to be dominated by the larger synoptic-scale pressure pattern instead of localized mesoscale effects. Although the average windspeed oscillates in a noticeable seasonal cycle, the wind direction remains quite constant. The annual wind rose (Figure IX-17), derived from 5 years of Smithville Airport operations, shows a strong component from the south that is duplicated throughout the year. Seasonal movement of the midlatitude storm track causes a slight redistribution of the southerly winds, but the annual wind rose is typically repeated during all seasons. For example, the annual frequency of winds from the southeast through south of 36.82 percent occurs on a seasonal basis as follows: winter 40.85 percent, spring - 32.95 percent, summer - 36.96 percent, and fall - 36.75 percent.

Both summer and fall are almost identical to the annual average, with winter and spring not significantly different.

While the wind pattern shows little seasonal tendency, there is a pronounced diurnal cycle that is marked by increasingly southerly winds during the night. There is a smooth progression of "random" winds during the day becoming increasingly organized during the night. The progression of southeast-south winds stratified according to their stability structure (highly unstable in mid-afternoon to slightly stable during the subsequent late night and early morning hours) is as follows:

$\begin{array}{ll}\text { Extremely unstable } & 18.1 \text { percent } \\ \text { Moderately unstable } & 24.2 \text { percent } \\ \text { Slightly unstable } & 28.9 \text { percent } \\ \text { Neutral-daytime } & 33.6 \text { percent } \\ \text { Neutral-nighttime } & 37.2 \text { percent } \\ \text { Slightly stable } & 43.1 \text { percent } \\ \text { Moderately stable } & 43.7 \text { percent } \\ \text { Extremely stable } & 48.9 \text { percent }\end{array}$




\section{DEKALB COUNTY \\ WIND ROSE DERIVED FROM FIVE YEARS OF OBSERVATIONS (1949-1953)}

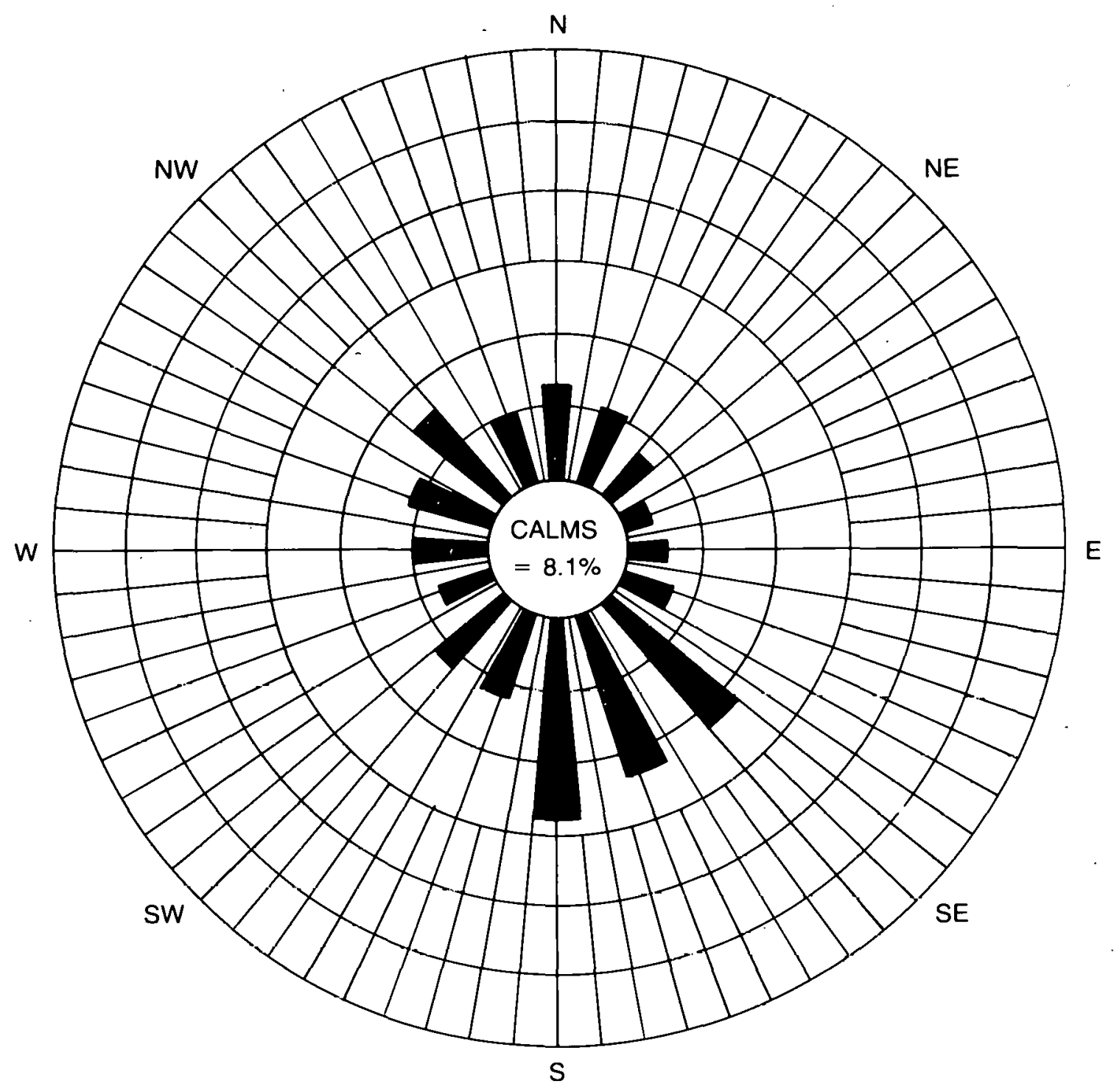

LOCATION - SMITHVILLE, TENNESSEE (ANNUAL)

FIGURE IX-17 
Just before sunrise, almost half the winds normally flow from a small 67.5 degree sector centered on the south-southeast. The increase in the frequency of nighttime south winds is due to a combination of weak pressure gradient and topographic effects that combine under quiet, stable conditions. During the daytime, the steering effects of the Cumberland Plateau and Short Mountain are negated as the convective currents act to more strongly couple the airflow aloft with the surface winds.

Windspeeds drop considerably both during the night on a diurnal basis and during the warmer months on a seasonal basis. The frequency of calm winds (speeds less than anemometer threshold speed) increases from slightly over 3 percent in winter to over 14 percent in summer. Despite decreasing speeds during the night, winds usually blow all night such that the DeKalb County area offers good dispersive potential for localized pollutant emissions.

The overall implication of the local windfield character is that the high frequency of winds from the south will concentrate any impact of low-level pollutants within a small area. Conversely, the low frequency of calms or light winds will not allow high concentrations to build up. Compared to locations on the Plateau or the Great Valley, the DeKalb County area is thus much better suited for pollutant dispersal because the breezes produce better diffusion conditions, even during the stable nighttime hours.

Wind roses for the diurnal and seasonal wind frequencies are provided in Appendix C. Although both sets of wind roses show considerable variation in the windfield that will redistribute shale processing-related emissions over a wide area, the dominance of winds from the south can be expected to promote a greater impact to the north and northwest of the site. Processing effluents and related pollutants will thus be more concentrated in the area around Center Hill Lake and possibly Smithville, particularly any materials emitted at night. Although the wind measurements are from only one site in the county, they are considered representative of the overall county airflow characteristics, especially on 
the flatter portions of the southern half of the county. If processing activities are eventually implemented in very complex terrain close to the western, northern, or eastern county line, additional wind data will be needed to supplement the present data base, but on the flatlands the available data are quite sufficient.

\section{HIGH WINDS AND STORMS}

Extreme winds for the Smithville Airport have been tabulated for only a relatively short period of record. Long-period estimates for the region indicate a probable 100-year maximum wind of $89 \mathrm{mph}$. Figure. IX-18 shows the regional calculations and a comparison with the observed four-year maximum wind at the Smithville Airport. The observed wind of $52 \mathrm{mph}$ fits very well with the projected regional values, thus the regional values shown in Table IX-6 appear to be well applicable to DeKalb County.

.The predicted fastest mile wind for a 100-year return period shows that a wind design value of 90-100 mph could be expected to offer a high degree of safety in most sustained winds except for transitory phenomena such as gusts, or brief violent storms such as tornadoes.

Hurricanes never directly affect the DeKalb County area, but their remnants may cause extremely heavy rains and possibly local flooding. The most devastating winds occur with the short-lived tornado, whose winds may reach $300 \mathrm{mph}$ at the funnel wall. Tornado frequencies for the southeastcrn Urited States surrounding DeKalb County have been estimated at two storms per $10,000 \mathrm{mi}^{2}$ per year. For the county, this yields an annual probability of 0.0552 for a tornado touching down somewhere within the county line. The inverse probability indicates that the county can be expected to experience one tornado every 18 years. As noted in the discussion of regional meteorology, any particular point in the county can expect one tornado every 7,040 years. Tornado statistics are sometimes misleading because they presume that all funnel clouds have actually been observed and reported for a sufficiently long period of record. Notwithstanding, the estimate of one "twister" about every 20 years appears consistent with observations in DeKalb County and a. number of adjacent counties of similar size. 


\section{REGIONAL PREDICTED SUSTAINED MAXIMUM WINDS COMPARED \\ TO SHORT-PERIOD DEKALB COUNTY OBSERVATIONS}

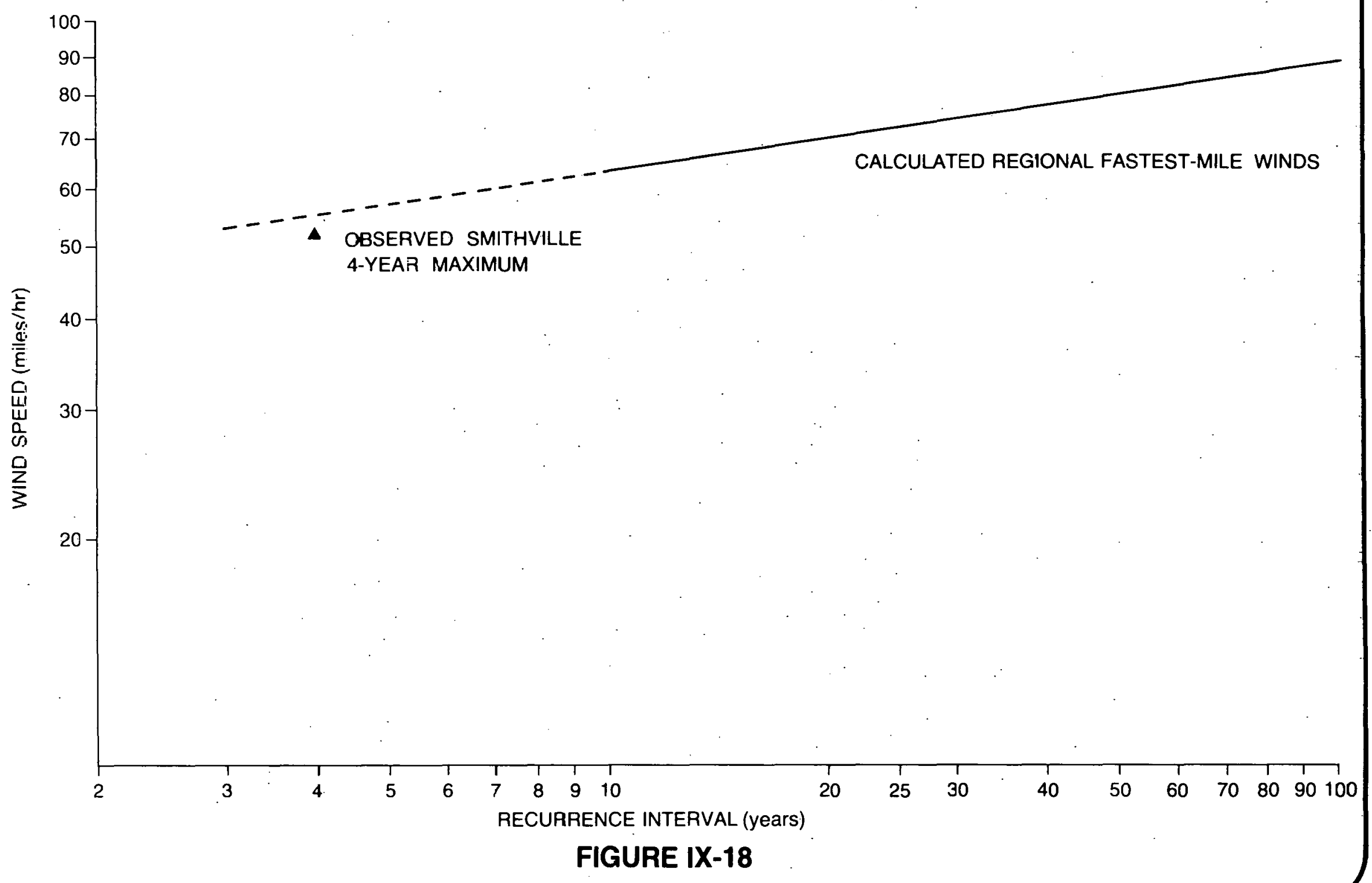


TABLE IX-6. PREDICTED MAXIMUM DEKALB COUNTY WINDS VERSUS RECURRENCE INTERVAL

\begin{tabular}{lcc}
\hline \multicolumn{1}{c}{ Interval } & Maximum Speed (mph) \\
\hline Once every & 5 years & 57 \\
Once every & 10 years & 63 \\
Once every & 20 years & 70 \\
Once every & 30 years & 74 \\
Once every & 50 years & 80 \\
Once every & 75 years & 84 \\
Once every 100 years & 89
\end{tabular}




\section{ATMOSPHERIC STABILITY}

The turbulent dispersion in both the horizontal and the vertical directions perpendicular to the downwind axis are critically dependent upon the stability stratification of the atmosphere. Since it is almost impossible to obtain actual dispersion data in advance of the construction of a project, reliance must be placed upon known or assumed relationships between meteorology and dispersion. Unfortunately, turbulence is a complex process in space and time which is only poorly parameterized by various schemes. Typically, as well, the input data are not of sufficient quality to permit accurate dispersion estimates even if the methodology were flawless.

Problems with atmospheric stability measurements are a prime example of the input data limitations. Typically unavailable are measurements with the temporal and spatial resolution necessary to characterize the many scales of atmospheric turbulence, and it is often not even clear what parameters should be measured. To compound the problem, the entire spectrum of dispersion estimates must typically be segregated into a small number of discrete categories (usually referred to as PasquillGifford stability classes) in order to simplify calculations. By structuring the atmosphere into a small number of artificial states, only very little of the actual variety. of atmospheric turbulent structure: is fully described. Since much of the stability class stratification research has been performed in environments considerably different than those where it $\mathrm{h} 2 \mathrm{~s}$ found ultimate application, it is also not clear to what extent such classification:schemes are applicable to their new environments. Nevertheless, the Pasquill-Gifford (P-G) classes and their related dispersion parameters are the semi-universally accepted methods for characterizing turbulence. Their distribution around DeKalb County is further described below.

Two common techniques are available for. stratifying meteorological data into their respective $P-G$ classes. When vertical temperature gradients are measured at a particular site, they are usually divided according to a set of guidelines promulgated by the Nuclear Regulatory Commission 
(NRC) and shown in Table IX-7. Vertical temperature gradients, or temperature difference measurements $(\Delta T)$, are available from a number of locations in Tennessee with tall meteorological towers, however no such data are available for DeKalb County.

In cases where these are unavailable, a cruder technique is utilized that relies solely upon a set of surface-based meteorological measurements and observations. This process, developed about 20 years ago in some of the early work of Pasquill [1961], Gifford [1961], and Turner [1964], is known as the STability ARray (STAR) program. STAR is a computerized processing of hourly weather observations (about 8,760 observations per year) that uses insolation, weather, sky conditions, and wind speed as discriminators. Table IX-8 indicates the breakdown used in the STAR program.

In order to provide an input data set of local stability conditions for later dispersion modeling, data have been processed reflecting 5 years of Smithville Airport weather observations by the National Climatic Center covering the years 1949-1953, inclusive. Since STAR values usually represent a much deeper layer of the lower atmosphere than $\Delta T$ measurements which are confined to perhaps the lowest $200 \mathrm{feet}$, there is considerable difference between the two techniques. The implications of these differences have been discussed by a number of researchers, but no conclusions about resolving $\triangle T$ /STAR differences have been reached. In most instances, $\Delta \mathrm{T}$ predicts a much higher frequency of daytime unstable and nightime stable conditions than STAR. STAR predicts far more neutral cases because the extremes of temperature structure are statistically smoothed out through a deeper layer of the atmosphere. Since the more restricted dispersion of nighttime stable conditions is balanced by the better daytime unstable ventilation, the two techniques usually lead lo similar long-term average dispersion estimates. For predicting short-term localized impacts from low-level sources, however, care must be exerctsed in using the stability class frequencies predicted by STAR. 
TABLE IX-8. (Continued)

3. For daytime with cloud cover $\leq 5 / 10$, radiation index = insolation class number.

For cloud cover $>5 / 10$, insolation class number is modified as follows:
a. Subtract 2 if ceiling $<7,000$ feet.
b. Subtract 1 if 7,000 feet $\leq$ ceiling. $<16,000$ feet
c. Subtract 1 if overcast $\geq 7,000$ feet.
d. If modified insolation class number 1 , let it equal 1.
e. Let radiation index $=$ modified insolation class number. 
TABLE IX-8. TURBULENCE CLASSIFICATION SCHEME USED IN THE STAR COMPUTER PROCESSING ROUTINE

\begin{tabular}{cccccccc}
\hline $\begin{array}{c}\text { Wind Speed } \\
\text { (Knots) }\end{array}$ & 4 & 3 & 2 & 1 & 0 & -1 & -2 \\
\hline $0-1$ & 1 & 1 & 2 & 3 & 4 & 6 & 7 \\
$2-3$ & 1 & 2 & 2 & 3 & 4 & 6 & 7 \\
$4-5$ & 1 & 2 & 3 & 4 & 4 & 5 & 6 \\
6 & 2 & 2 & 3 & 4 & 4 & 5 & 6 \\
7 & 2 & 2 & 3 & 4 & 4 & 4 & 5 \\
$8-9$ & 2 & 3 & 3 & 4 & 4 & 4 & 5 \\
10 & 3 & 3 & 4 & 4 & 4 & 4 & 5 \\
11 & 3 & 3 & 4 & 4 & 4 & 4 & 4 \\
$\leq 12$ & 3 & 4 & 4 & 4 & 4 & 4 & 4 \\
\hline
\end{tabular}

Stability 1 = Extremely Unstable

Stability 2 = Moderately Unstable

Stability $3=$ Slightly Unstable

Stability 4 = Neutral (may be broken down into day/night subgroups)

Stability 5 = Slightly Stable

Stability 6 = Moderately Stable

Stability 7 = Extremely Stable

To determine radiation index, the insolation class number is first calculated as shown:

Solar Elevation - Insolation Insolation Class Number

(c)

$$
\begin{gathered}
\propto>60^{\circ} \\
35^{\alpha} \propto \leq 60 \% \\
15^{\alpha} \propto<\leq 35 \% \\
\propto \leq 15^{\circ}
\end{gathered}
$$

Strong
Moderate
Slight
Weak

Strong

Slight

Weak

$$
\begin{aligned}
& 4 \\
& 3 \\
& 2 \\
& 1
\end{aligned}
$$

Insolation class number is modified as follows:

1. For total cloud cover below 7,000 feet, radiation index $=0$, independent of insolation class number.

2. For nighttime with cloud cover $s 4 / 10$, radiation index $=-2$;

For nighttime with cloud cover $>4 / 10$, radiation index $=-1$. 
TABLE IX-8. TURBULENCE CLASSIFICATION SCHEME USED IN THE STAR COMPUTER PROCESSING ROUTINE (Continued)

3. For daytime with cloud cover $\leq 5 / 10$, radiation index = insolation class number.

For cloud cover $>5 / 10$, insolation class number is modified as follows:

a. Subtract 2 if ceiling $<7,000$ feet.

b. Subtract 1 if 7,000 feet $<$ ceiling $<16,000$ feet

c. Subtract 1 if overcast $>7,000$ feet.

d. If modified insolation $\bar{c}$ lass number $\times 1$, let it equal 1 .

e. Let radiation index $=$ modified insolation class number. 
The Smithville P-G class distribution is shown in Figure IX-19. Twenty-nine percent of all cases are very stable, 11 percent are very unstable, and a very high 60 percent are neutral, slightly stable, or unstable. Both the excellent ventilation due to high wind speeds and the good vertical mixing due to neutrally stratified structure indicates that DeKalb County offers considerable potential for atmospheric dispersion of uranium shale-related effluents. These characteristics are not unique to the county, but encompass a wide area of Tennessee west of the Cumberland Plateau. These are an indication, that if present pollutant levels in the area are relatively low the area can accommodate considerable development without affecting the long-term quality of life as it relates to clean air.

As indicated previously, the STAR technique may not correctly predict the frequency of extremely low-level effects. In order to obtain some insight into this difference, a comparison of the Smithville STAR run with a set of $\Delta T$.measurements at Oak Ridge is plotted in Figure IX-20. There are significant differences in all categories, especially the P-G Category $A$ and $D$ cases. Although the two methods show fair agreement in the very stable cases, they disagree uniformly throughout all the remainder. If the worst-case conditions are associated with Category $G$, the two methods would yield similar results. Interestingly, if it is assumed that dispersion varies linearly with stability class [i.e., category A dispersion assumed 7 times better than G], the STAR technique predicts average concentrations that are 99.95 percent that of the $\Delta \mathrm{T}$ frequency. Rather; if it is assumed that dispersion varies as the square of the class [i.e., Category A dispersion assumed 49 (7x7) times better], STAR predicts 92.52 percent of $\Delta T$. Finally, under the assumption of a cubic variation, which is closer to reality at moderate downwind distances [i.e., Category A dispersion assumed $343(7 \times 7 \times 7)$ times better than Category G], STAR predicts 87.00 percent of the $\Delta T$ values. Since Oak Ridge values in the ronfined topography of the Great Valley would be expected to yield higher concentrations because of poorer dispersion, the agreement between the two techniques is indeed remarkable but in the 


\section{DISTRIBUTION OF PASQUILL-GIFFORD STABILITY CLASSES FOR DEKALB COUNTY DERIVED FROM NOAA STAR PROGRAM (1949-1953)}

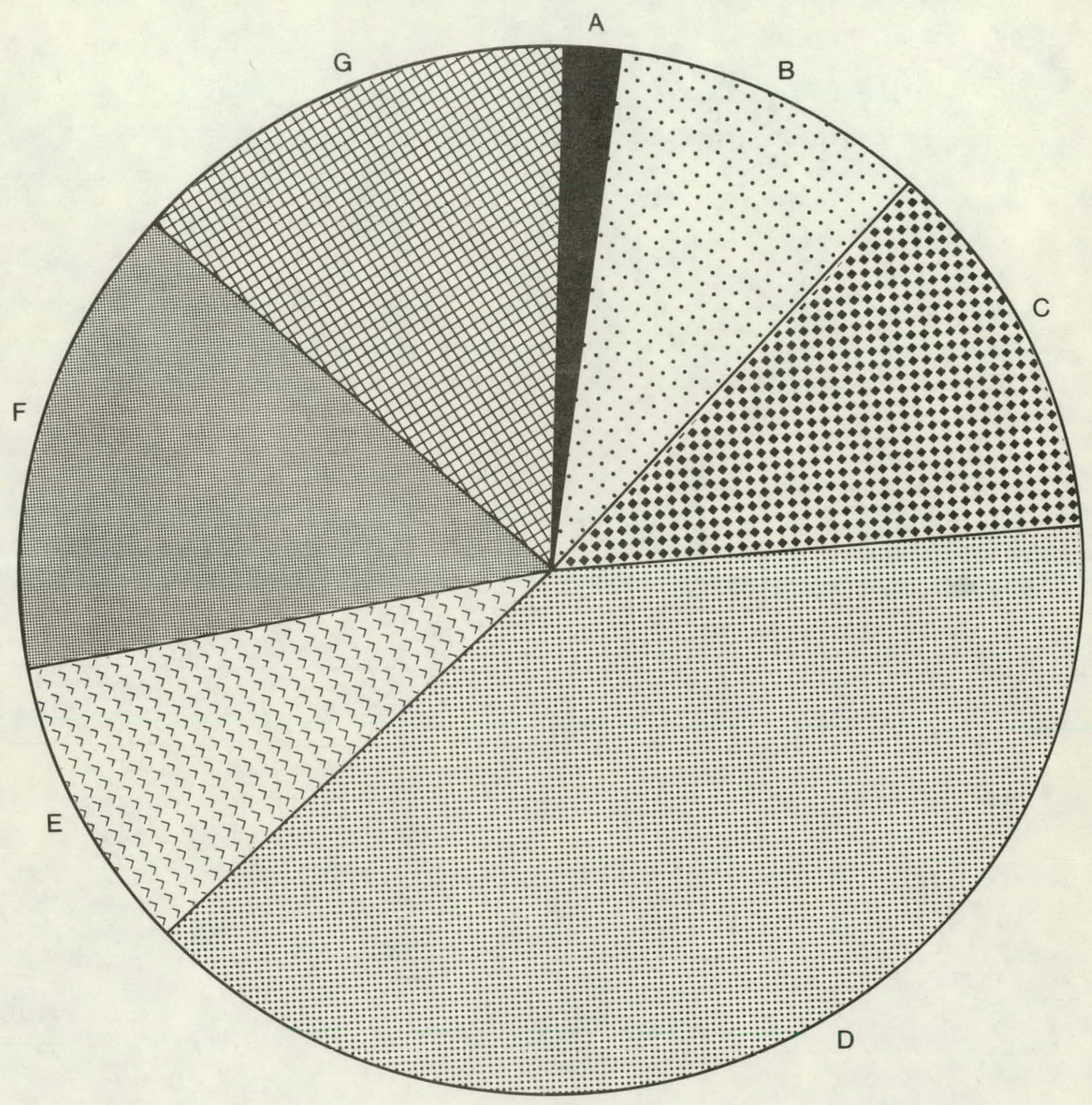

FIGURE IX-19 
STABILITY

A

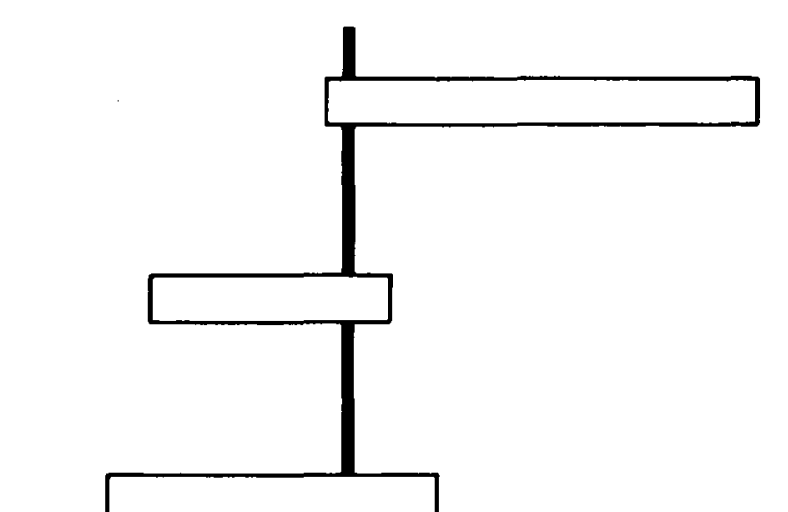

EXCESSIVELY UNSTABLE

B

C

MODERATELY UNSTABLE

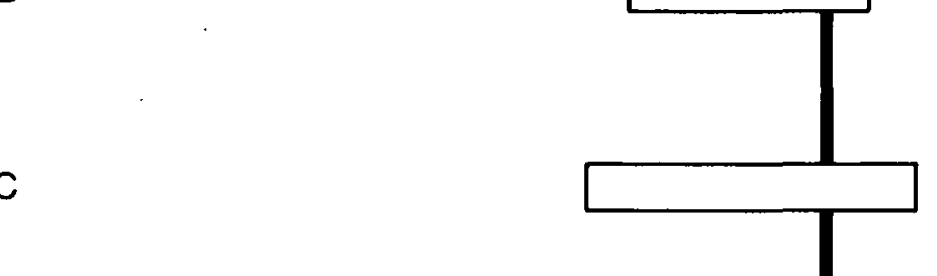

$\mathrm{D}$

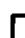

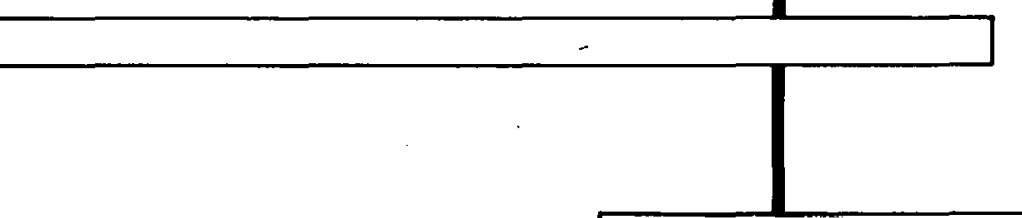

SLIGHTLY UNSTABLE

$E$

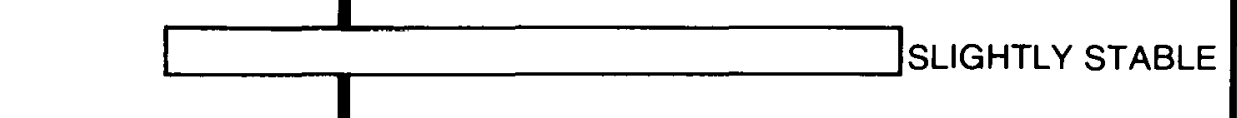

$\mathrm{F}$

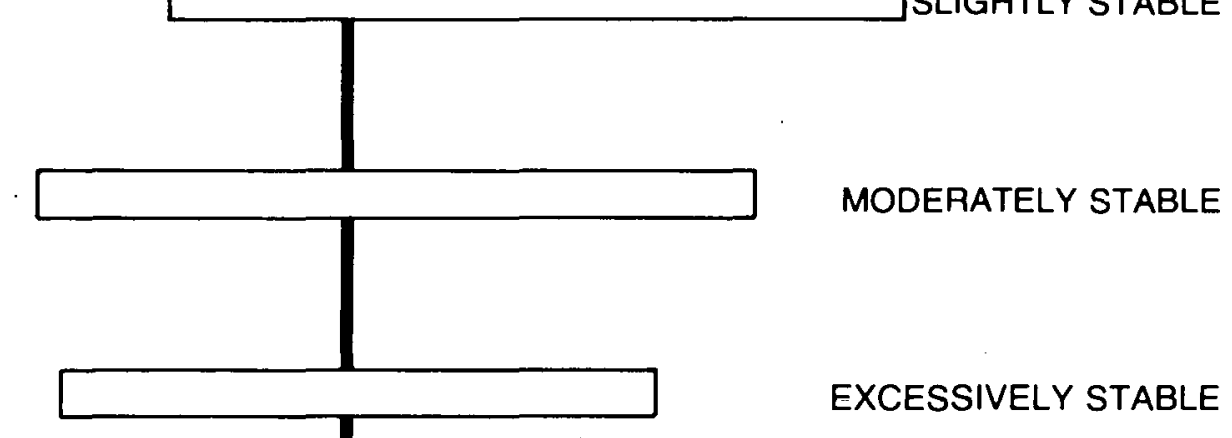

G

$35 \%$

$30 \% \quad 25 \% \quad 20 \%$

$15 \% \quad 10 \% \quad 5 \%$

$5 \% \quad 10 \% \quad 15 \% \quad 20 \%$

$25 \% 30 \%$

FREQUENCY

NEUTRAL

FIGURE IX-20 
direction one would expect from the topographical considerations. Given the good agreement between these two methods, one may assume that the STAR stratification for DeKalb County will yield very realistic results in the air quality impact modeling analysis presented in Section XII. 


\section{SECTION $\mathrm{X}$ \\ WATER RESOURCES}

This section analyzes the potential impacts upon surface and groundwater availability and quality that might result from extraction, processing, and disposal activities associated with the contemplated project.

\section{DESCRIPTION OF EXISTING CONDITTONS}

The existing nature of surface and groundwater distribution and quality, and present utilization is described below at the regional and local levels.

\section{REGIONAL CHARACTERIZATION}

Rather than attempt the unwieldy task of characterizing the nature of the hydrologic regime for the regional study area as a whole, the area is considered below in three major components: south-central Kentucky, northern Alabama, and central Tennessee. The detailed treatment later in this section of the DeKalb County area is considered sufficient to constitute a description of the central Tennessee component, therefore the following discussion is limited to the other two.

\section{South-Central Kentucky}

Data availability and the known presence of Chattanooga Shale uranium ore values suggest the Allen County area as an appropriate focus for the following descriptive narrative. Indications are that the description provided may be considered applicable to the entire south-central Kentucky area in question. 


\section{Surface Water Distribution}

In the regional area of Allen County, occurrence of surface water is attributable to runoff of local precipitation, discharge of groundwater, and inflow of streams from adjacent areas. The surface water regime is subject to depletion from evaporation, transpiration, regional outflow, and percolation to groundwater basins. Surface waters serve as a supply source for stock, domestic, and irrigation uses.

Principal surface waters in south-central Kentucky include the Barren, Green, Nolin, Cumberland, Gasper, Red, and Mud Rivers. With the exception of the Red River, which is situated in the Cumberland River drainage, all of the foregoing rivers are tributaries of the Green River, which empties into the Ohio River.

Streams that traverse the Allen County area typically flow in a generalized northward direction. Flows are tributary to the Barren River, a significant watercourse in south-central Kentucky. A major impoundment on the Barren River, Barren River Lake, dominates the northeastern boundary of Allen County. Barren River drains to the northwest. across central Kentucky, where it supplies the Green River, which eventually discharges to the Ohio River.

Discharge records have been maintained for the Barren River above Hurricane Creek since 1939. Flows of the West Bays Fork at Scottsville have been gaged since 195?. Data have been analyzed to determine the frequency of the annual low flow on West Bays Fork and Trammel Fork (from partial-record data) in Allen County as well as for other unregulated streams in Kentucky [Swisshelm 1974]. For West Bays Fork and Trammel Fork, 7.-day, 10-year low flows are zero, and $4.5 \mathrm{cfs}$, respectively. Corresponding drainage areas for these streams are 7.47 and 93.4 square miles..

\section{Surface Water Quality}

Water quality of most surface drainage courses in south-central Kentucky appears to be suitable for most beneficial uses. Total dissolved solids 
content ranges from approximately 100 to slightly over $200 \mathrm{mg} / 1$. Hardness is typically on the order of $100 \mathrm{mg} / 1$, with a range from 80 to 140 considered typical. Waters are slightly alkaline, exhibiting a $\mathrm{pH}$ of 7.5 to about 8.0 [Mull, et al. 1971].

\section{Groundwater Distribution}

The geology and groundwater resources of the Scottsville Area, Kentucky have been reviewed in detail in a paper prepared by' USGS [Hopkins 1963], from which most of the following information has been summarized. The Scottsville Area defined by the paper encompassed about 240 square miles in south-central Kentucky, consisting of 215 square miles in Allen County and 25 square miles in Barren County. Most groundwater in the Scottsville area is derived from local precipitation. Streams in the region may serve to recharge the groundwater aquifer at locations and times where the water table adjacent to the surface watercourse is lower than stream elevation.

The Scottsville area is underlain by limestone, shale, and shaley, cherty limestone which range in age from Silurian to Mississippian. A mantle of residual and transported unconsolidated material of Pleistocene and Recent age overlies the bedrock. The Louisville Limestone Formation of Silurian age yields large volumes of fresh groundwater wherever the connate sulfurous or saline water has been flushed from solutional openings of pre-Chattanooga. age that are in the formation. In the Scottsville area, the largest known springs derive their supplies from solutional openings in the Louisville formation. The municipal water system of Scottsville is derived from one of the larger springs.

Perched or semi-perched waters are found in the Warsaw and St. Louis. Limestone Formations of Mississippian age, but quantities are usually insufficient for domestic requirements. Of the wells and springs inventoried in the Scottsville area, 23 and 21 percent, respectively, yield water from the Warsaw and St. Louis limestones. At the base of the Warsaw Limestone, water can be obtained in quantities sufficient for domestic or stock use, but quality is generally.poor due to high sulfur content. 
of the wells and springs inventoried, approximately 50 and 38 percent, respectively, derive their source water from the Fort Payne Chert of Mississippian age. Flows are attributable to water in solutional openings at the contact between overlying soluble and underlying less soluble strata. Flow through such openings is typically rapid. Water supplies obtained from the Fort Payne are generally small, in quantities suitable for domestic and stock use.

The'mantle rock of Pleistocene and Recent age typically yields small supplies of water sufficient for domstic and stock use. Of the wells inventoried in the Scottsville area, more than 16 percent relied on supplies derived from mantle rock. Forty percent of the springs inventoried yielded water from this source.

Recharge to the Chattanooga Shale is accomplished by infiltration of precipitation and streamflow on the area of outcrop, and by interformational leakage from the mantle rock and the Fort Payne Chert. It should be noted that recharge to the Chattanooga Shale from all sources is small in the Scottsville area except where the joints within the formation have been enlarged by slumping, as at outcrops.

Groundwater levels in the area studied exhibit fluctuations which typically correspond to seasonal variation. In springtime, water levels tend.to rise due to availability of water for recharge. This period is followed by one of gradual recession of levels to a low in fall or early winter. Depth-to-water $i s$ generally less than 50 feet in most areas of south-central Kentucky.

Subsurface movement of water includes percolation, flow of water through large fissures or openings, capillary migration, and circulation of water vapor. Capillary migration and circulation of water vapor are restricted to the zone of aeration exclusively. Major conduits for water in the chert, shale, and limestone consist of enlarged joints and bedding plane openings. In the Scottsville area, joints are generally nearly vertical, and bedding planes are characteristically nearly horizontal. 


\section{Groundwater Yield}

The two largest springs in the Scottsville area exhibit a range of flow which corresponds to 400 to $8,300 \mathrm{gpm}$, and 1,225 to $20,900 \mathrm{gpm}$, respectively. of the 1,199 springs inventoried in the Scottsville area, only about 1 percent issue from the Louisville Limestone. However, associated flows are so large that they discharge nearly as much water as the combined total yield of all other inventoried springs in the Scottsville area. The median and mean discharge of all inventoried springs is approximately $5 \mathrm{gpm}$.

Another hydrologic investigation conducted by USGS [Brown and Lambert 1962] documents availability of groundwater in a 10-county area of south-central Kentucky. Wells and springs inventoried as part of the study are described in terms of location, yield, depth-to-water below land surface, depth of well below land surface, type of lift, and waterbearing formation. Well yields indicated typically are not large. When larger production is achievable, flow rates are characteristically suited to domestic or stock use (approximately 500 gallons per day).

\section{Groundwater quality}

Limestone constitutes the dominant formation underlying the Scottsville area. Calcium carbonate is the principal chemical constituent of these rocks. In some rocks, chiefly Silurian, calcium magnesium carbonate is an important additional consituent. lhe quality of groundwater is greatly affected by the dissolving action nf. water upon limestone. In fact, water-bearing openings in the limestone are attributable to the solvent action of groundwater. The typical water from the limestone is moderately to very hard and slightly alkaline.

Water from the mantle rock, although moderately hard, is generally softer than that from the consolidated rocks. Iron content is also typically lower. Nitrate contamination of groundwater present in the mantle rock is fairly common. Sources of nitrate include decaying plant and animal matter. A chemical analysis of groundwater in the area is available in Hopkins [1963]. 


\section{Water Resources Development}

During the course of the groundwatèr resources investigation conducted in the Scottsville area [Hopkins 1963], 902 wells were inventoried, a number representing approximately 80 percent of the total existing in the area. Total well density was about 4 to 5 per square mile. Almost all wells yielded only small supplies for domestic and stock watering purposes. Development of springs in the Scottsville area has been oriented towards supplying the needs of homes and livestock. Water occasionally is used for irrigation. The city of Scottsville has developed one of the largest springs in the area for municipal purposes.

Surface as well as groundwater supplies have been developed for municipal use in the area. With the exception of Scottsville (Allen County), Green River Valley Water District (Hart County), Auburn (Logan County), Northside Water District (Warren County), and Smiths Grove (Warren. County), most of the major public water supply systems serving populations greater than approximately 600 utilize surface water sources.

Major impoundments in south-central Kentucky include the following [Hensley-Schmidt, Inc. 1973].

- Barren River Reservoix (situated between Bowling Green and Glasgow on the Barren River - surface acreage ranging from 3,500 to 20,000 )

- Nolin River Reservoir (north of Brownsville on the Nolin River --surface acreage ranging from 2,000 to 5,800 )

- Lake Malone (northwest of Lewisburg on Rocky Creek -- surface acreage approximately 800 )

Smaliler impoundments include:

- Shanty Hollow (north of Bowling Green in Warren County -- surface acreage approximately 106)

- Coon Range Lake (Logan County -- surface acreage approximately 16)

- Lewisburg City Lake (Logan County -- surface acreage approximately 51) 
- Briggs Lake (Logan County -- surface acreage approximately 11)

- Lake Herndon (Logan County -- surface acreage approximately 142)

- Big Reedy No. 9 Lake (Edmonson County -- surface acreage approximately 47)

- Mount Gilead Lake (Monroe County -- surface acreage approximately 14)

- Tompkinsville Lake (Monroe County -- surface acreage approximately 10)

\section{Northern Alabama}

Data availability directs emphasis in the following characterization to the Madison County area of northern Alabama. This area may be regarded as typifying hydrologic patterns in the northern Alabama regional area. The bulk of the information reported herein has been derived from the results of a recent USGS geologic survey of Alabama [Moser and Hyde 1975].

\section{Surface Water Distribution}

The established surface water drainage pattern of northern Alabama consists of tributaries of the Tennessee River which flow in a generally southerly direction. In each tributary river basin; surface runoff follows a system of downslope flow paths from the drainage divide to the nearest channel, and subsequently into the basin's main water course. Flow in channels enters the groundwater system through sinks in a few small, localized areas.

A mean annual overland water flow of about 10 inches derived from areal precipitation collects in the Tennessee River via the channels of its tributaries. Of the total volume of average yearly precipitation, approximately 11 inches infiltrates through the soil profile to groundwater. Hence, combined potential water available for use from both the surface and subsurface regimes is 21 inches, or slightly less than 43 percent of the total precipitation. 
The Tennessee River has become a major artery for the transportation of raw and manufactured products. The river satisfies approximately one-half $(26.7 \mathrm{mgd}$ ) of the total demand for water in Madison County. Water resource acquisition for public, industrial, an commercial supplies has been occurring since the 1950's. Flow in the Tennessee River averages $28,000 \mathrm{mgd}$.

\section{Surface Water Quality}

In northwestern Alabama, calcium and bicarbonate are the most common minerals dissolved in surface water. Sodium, potassium, chloride, fluoride, nitrate, and sulfate are typically present in only minor amounts.

The high calcium and bicarbonate concentrations are attributable to the widespread contact of limestones and cherty limestones with surface and subsurface waters. TDS reportedly ranges from 36 to $175 \mathrm{mg} / 1$ in surface supplies; hardness varies from $18 \mathrm{mg} / 1$ (soft) to $148 \mathrm{mg} / 1$ (hard). Hardness is the most significant characteristic of surface water in the Madison County area. Water is generally classified from soft to moderately hard, and is therefore suitable for most uses.

\section{Groundwater Distribution}

Groundwater is reportedly the most abundant natural resource in Madison County and other areas of northern Alabama. Occurrence of groundwater is associated with the regolith above bedrock and in cavity systems in limestone. A few cavity systems may provide yields of several thousand gallors per minute to individual wells.

It is difficult to evaluate groundwater availability in areas of limestone terrain because of problems incurred in describing the direction, size, and extent of solution openings in which groundwater is found. In Madison County, an analysis of approximately 2,000 well and spring 
records provided data which yields insight into generalized patterns of groundwater availability. Characteristics are as follows:

- Groundwater occurs in permeable zones in the regolith

- Groundwater occurs in solution openings in limestone above the Chattanooga shale

- In the northern part of Madison County, a few wells have penetrated water-bearing openings below the Chattanooga Shale.

Regolith refers to all unconsolidated material above bedrock; overburden, residuum, and the engineering connotation of soil are synonyms. Some regolith is attributable to materials which have traveled downslope in response to gravity or to those which have been deposited in river channels and flood plains as alluvium. The bulk of regolith, however, is derived from weathering of bedrock in place. Processes of chemical decomposition and mechanical disintegration of limestone and other rocks typically assist leaching of water-soluble materials. The insoluble residual mantle which subsequently remains above unweathered or partly weathered bedrock is composed of clay, silt, sand, and dispersed rock fragments.

If prcoent in suffirient thickness, regolith functions as an aquifer. Where cherty limestone of the Tuscumbia Limestone and Fort Payne Chert are located at relatively significant depths below the land surface, cavity systems tend to be less well-developed than those which characterize these formations at shallower depths. Solution cavities frequently are found in areas underlain by limestone. Sinkholes are usually created as a result of solution of surficial limestone; however, collapse of a cave roof can also be the cause. Tuscumbia Limestone and Fort Payne Chert typically contain greater and more productive cavity systems than the limestone formations by which they are overlain.

In northern Alabama, the lower part of the regolith is composed of cherty materials that readily transmit water. The upper part of the regolith is a less permeable clayey material that serves as a confining layer in most areas. Confined water under this layer is under pressure. It will rise above the base of the confining layer when the clay formation is penetrated by drilling, an artesian condition. 
Generalized trends in groundwater movement have been identified for selected regions of northern Alabama. Subsurface flow typically occurs at right angles to potentiometric contours and reflects the influence of surficial topography. Movement of groundwater is characteristically from north to south in Madison County.

\section{Groundwater Yield}

Well productivity in limestone is a function of the size and extent of cavity systems and the degree of interconnection between the cavity system and area of recharge. The majority of springs discharge from cavity systems in limestone. Flow rate of an individual spring typically may exhibit considerable variation. Yields of wells and springs in northern Alabama generally are at least comparable to, and usually greater than, those which characterize the DeKalb County, Tennessee, area .

For example, an inventory of the 150 wells and springs: in Madison County with yields in excess of $100 \mathrm{gpm}$ provided the following yield distribution:

$\begin{array}{cc}\begin{array}{c}\text { Yield } \\ \text { (gpim) }\end{array} & \begin{array}{c}\text { Percent } \\ \text { of Toral }\end{array} \\ \text { 100-249 } & 44 \\ 250-499 & 31 \\ 500-1000 & 8 \\ 1000+ & 17\end{array}$

Factors conducive to high groundwater yields in the area include: thick regolith; shallow water levels with small seasonal fluctuation; extensive open cavity systems.

Primary factors which influence fluctuation in groundwater levels of the area include pumpage, precipitation, and recharge. Most water levels are highest during winter or spring when precipitation is greatest, and decrease to annually low levels during fall when precipitation is least. 
In Madison County, the range of fluctuation is fairly uniform.

Excessively high amplitude of fluctuation is an anomaly associated with wells on steep slopes, or wells situated in areas of concentrated pumpage. In areas of large natural water-level fluctuation, wells tend to have yields that vary with time. This is especially evident where water levels decline below cavity systems and in areas where the saturated thickness of the aquifer is small.

Direction of groundwater movement has been analyzed in northwest Alabama by Moser and Hyde [1974]. In Lauderdale County, groundwater moves mainly toward the south. Subsurface flow in Colbert County is northward to the Tennessee River. In the western portion of Colbert County, groundwater travels in a westward trending direction toward Bear Creek.

\section{Groundwater Quality}

The most common constituents in groundwater underlying Madison County, Alabama, include calcium, magnesium, and bicarbonate. Other dissolved minerals are present in only minor amounts. Concentrations of iron, sulfate, nitrate, chloride, and fluoride exceed recommended drinking water standards in localized areas. Degradation attributable to human activity has also caused minor metal content of localized groundwater to exceed drinking water standards. Groundwater generally exhibits a quality suitable for most applications. Hardness is the only parameter in Madison County that may inhibit some beneficial uses.

Groundwaters in northwest. Alabama generally possess higher concentrations of dissolved minerals than do surface waters. Several factors influence the chemical character of subsurface water resources. Among these are composition of the aquifer, distance from recharge areas, travel and contact time of water in the aquifer, and overall patterns of groundwater circulation.

With the exception of groundwaters associated with the Gasper Formation north of Littleville, almost all water derived from limestone aquifers usually contains less than $500 \mathrm{mg} / 1$ TDS. Hardness ranges from hard to very hard. 


\section{Water Resources Development}

The existing character of streams in northern Alabama is attributable to several factors, among which are included the perennial nature of streams in the semi-tropical southeast, and resource development activities oriented toward accommodating requirements of power generation, flood control, recreation, and municipal/industrial water use.

Water in tributaries of the Tennessee River in Madison County is virtually undeveloped. In only a few scattered instances do flows in tributary streams supply industry or recreation. Streams provide habitat for fish, and serve to asimilate and transport waste discharges.

A considerable number of potential impoundment sites are available in northern Alabama. Water resource development projects could provide for storage of water during periods of high flows to reduce possible hazards of flooding. Base flows could be increased for dependable water supplies, recreation, fish habitat, and waste assimilation and transport.

Groundwater is used extensively as a source of water supply in northern Alabama. In Madison County, about one-half the source water of Huntsville is derived from subsurface supplies. Excluding Redstone Arsenal, nearly 100 percent of all remaining public and private water systems in the county rely upon groundwater. The resource is not taxed; data indicate that much additional groundwater can be utilized as necessitated by increased demard.

The principal water system in Madison County of a county-wide nature is in the Huntsville area. Consolidation of neighboring systems with Huntsville has occurred; however, the trend of regional water supply in no way equates to the activity experienced in this regard in DeKalb County, Tennessee. 


\section{LOCAL CHARACTERIZATTION}

\section{Surface Water Distribution}

A report prepared recently by the State of Tennessee Division of Water Resources [Moore and Wilson 1972] has defined the nature and availability of water resources in the Center Hill Lake region of Tennessee. The geographic extent of the region addressed corresponds to all of DeKalb County, and portions of Smith, Wilson, Cannon, Warren, White, and Putnam Counties. Approximately 909 square miles in central Tennessee are encompassed by the Center Hill Lake region, almost equally distributed between the Central Basin and the Eastern Highland Rim. The inventory of water resources provided by the Center Hill Lake regional hydrologic investigation is extremely thorough; hence, it will serve as the basis for the resource summary presented herein.

\section{Streams}

Water in the DeKalb County/Center Hill Lake region is contributed by precipitation in the form of rain, snow, or sleet, as discussed in detail. in Section IX. The major component of streamflow is attributable to overland surface runoff; however, some river accretions are provided by water which moves through the soil profile.

Measurements or computations of streamflow have been conducted for approximately 802 of the 909 square miles in the Center Hill Lake region [Moore and W1lson 1972]. The average amount of annual precipitation expressed as streamflow is on the order of 17 inches, which means that about 36 inches of water evaporates or is transpired. Studies conducted at Center Hill Dam have determined that approximately 73 percent of this annual water loss, about 26 inches, occurs during the growing season, April through September [Nave 1961]. Average and low flows of selected streams in the Center. Hill Lake region are presented in Table $\mathrm{X}-1$. and depicted on Figure X-1 (DeKalb County only). 


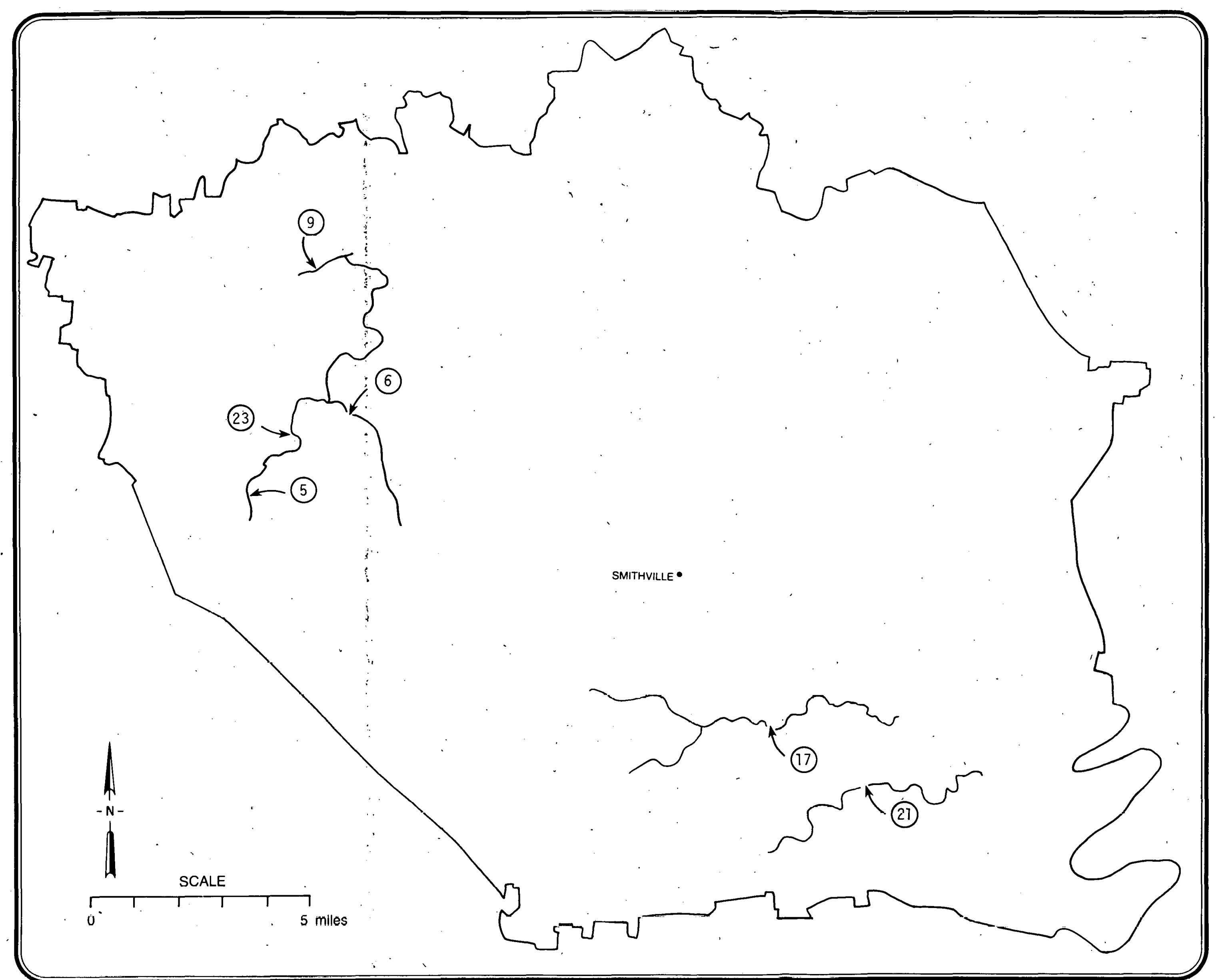

STREAMFLOW

IN DEKALB COUNTY

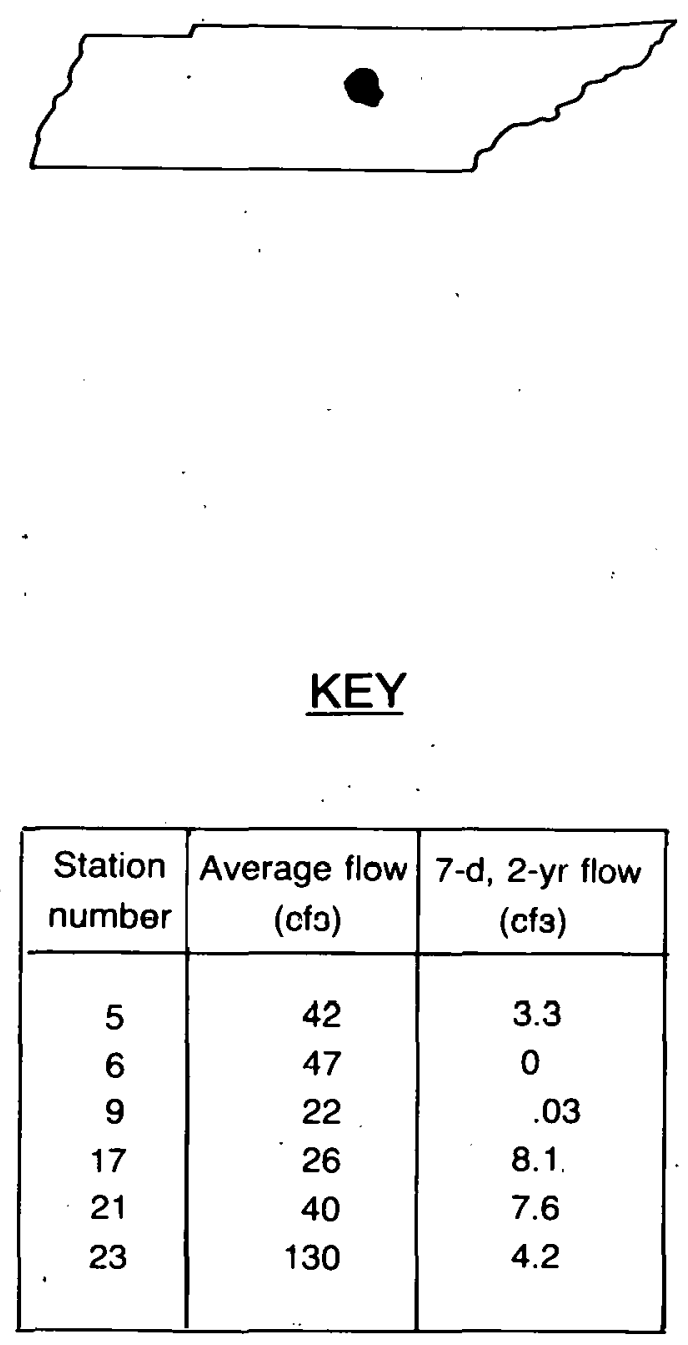

FIGURE X-1 


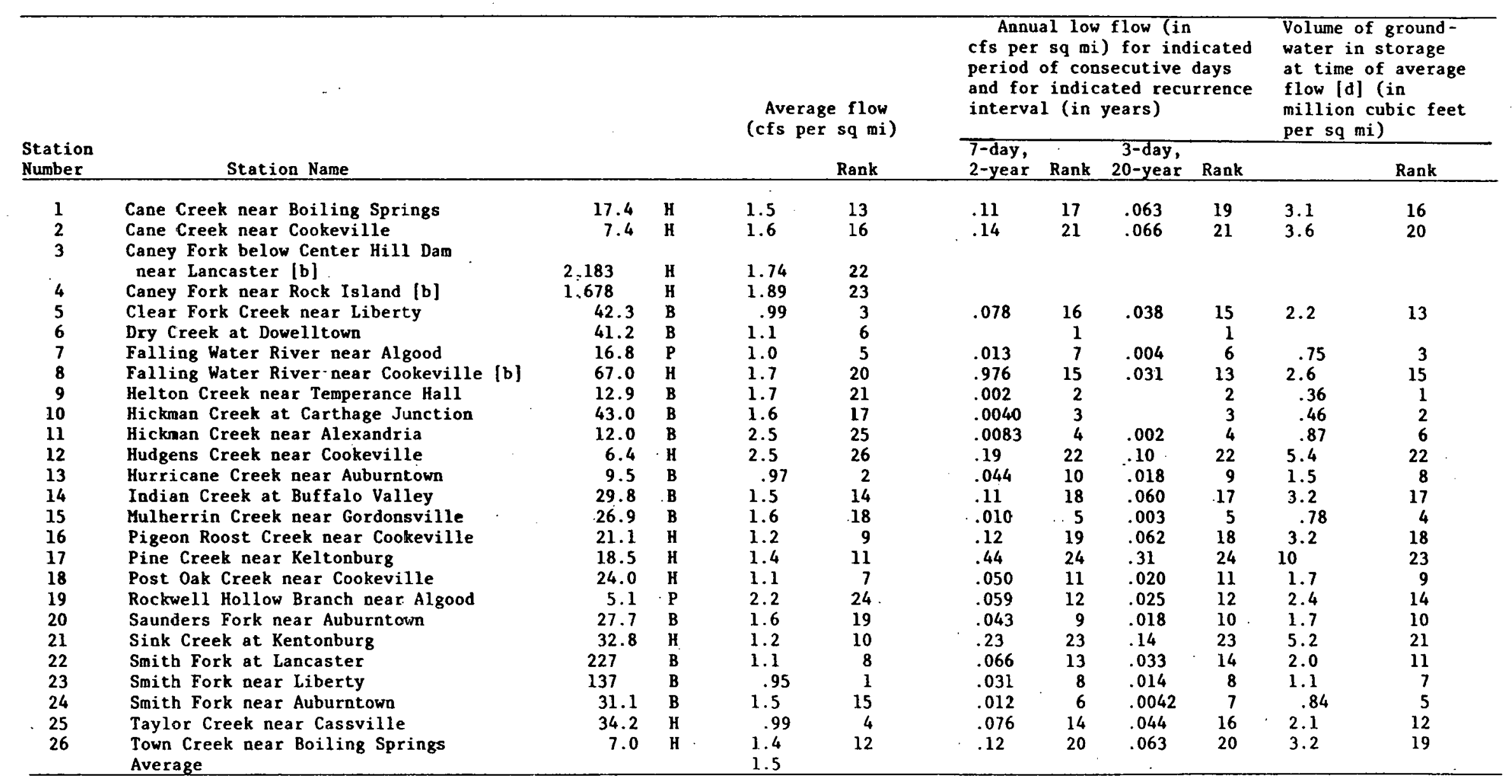

[a] Source: Moore and Wilson [1972]

[b] Gaging station with 24 years or more of record.

[c] $\mathrm{H}=$ Highland Rim; $\mathrm{B}=$ Central. Basin; and $\mathrm{P}=$ Cumberland Plateau. 
While most springs in DeKalb County discharge less than $50 \mathrm{gpm}$, some have been identified with discharges of several hundred gallons per minute. Most of these springs are at an elevation above 1,000 feet. The city spring in Smithville, which formerly supplied the town's water, is at an elevation of about 1,050 feet. Its flow is in the range of several hundred gallons per minute. The city spring is located approximately 130 feet above the top of the Chattanooga Shale, and other sizable springs in the county also occur well above the elevation of the shale formation. Figure $X-2$ depicts the locations and flows of springs in DeKalb County.

\section{Center Hill Reservoir}

Center Hill Reservoir is the largest reservoir in the Upper Cumberland River basin. Its pool encompasses the Caney Fork River from rivermile 26.6 to 89.0 . The tributary drainage area is 2,195 square miles. The reservoir is one of the multipurpose projects in the Army Corps of Engineers' coordinated plan for development of water resources of the Cumberland River basin.

Center Hill Dam and Lake is an integral part of a comprehensive resource development plan for the Ohio and Mississippi Rivers. The structure functions to control floodwaters of the Caney Fork River, and contributes to the reduction of flood heights downstream along the Cumberland, Lower Ohio, and Mississippi Rivers. The project also augments the electric power supply of the regional area. The dam impounds a reservoir 64 miles lang at water surface elevation 685 feet. Shoreline at this elevation, 415 miles in length, extends into DeKalb, Warren, White, and Putnam Counties. Storage is 2,092,000 acre-feet. The upper portion of the reservoir is used exclusively to accommodate floodwaters which otherwise would contribute to the severity of downstream flooding. Flood attenuation is provided by 37 feet of reservoir stage, containing 762,000 acre-feet of storage [U.S. Army Corps of Engineers, Undated]. 


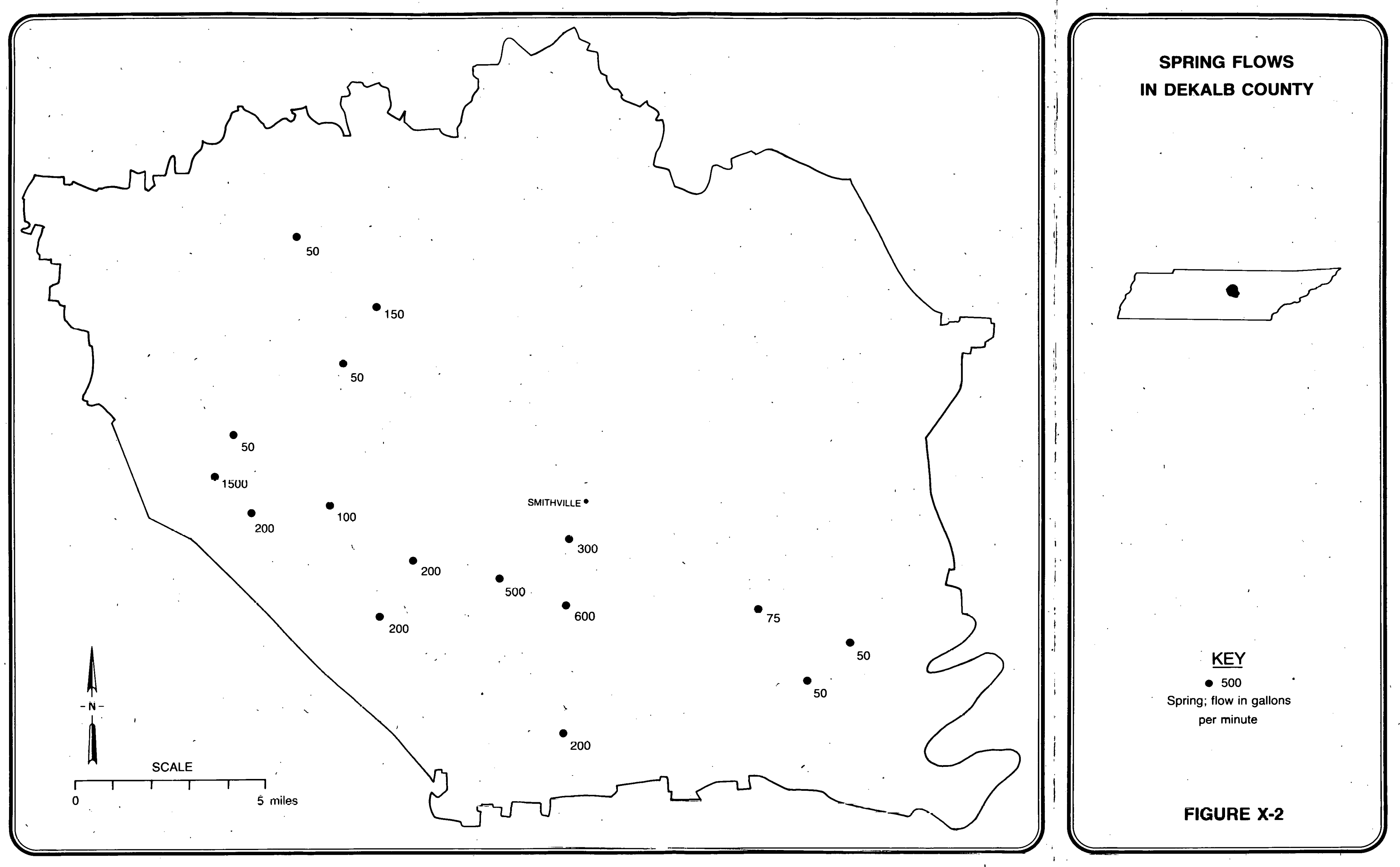


of the remaining $1,330,000$ acre-feet of reservoir capacity, 492,000 acre-feet are allocated to power generation. This corresponds to a drawdown of 30 feet. A minimum storage pool of at least 838,000 acrefeet is permanently maintained for recreation. Minimum pool elevation is 618 feet, inundating an area of 14,590 acres. At normal full pool level, elevation 648 feet, approximately 18,220 acres are covered. Full flood storage may expand to cover 23,060 acres.

\section{Groundwater Distribution}

Groundwater commonly occurs in formations which underlie the Center Hill Lake regional area. In the Highland Rim area of DeKalb County, the principal source and use of groundwater is from the Fort Payne Formation which overlies the Chattanooga Shale (for a detailed description of this formation, refer to Sections II and VIII). The depth of individual water wells generally does not exceed 150 feet, and most wells are developed to depths of 60 to 125 feet in the Fort Payne Formation. The overburden depth generally ranges from 20 to 50 feet, as depicted in Figure $X-3$. In describing the Fort Payne aquifer herein the entire formation, the section of bedrock and overburden which occurs from the top of the Chattanooga Shale to the surface, is considered. Within the entire unit there are sub-aquifers which might be identified; however; consideration of these is beyond the scope of this report.

It should be further noted that while there have been instances in which water wells have been reportedly developed from water occurring within the Chattanooga Shale, this contention has always been suspect because of the possibility that the shale water actually was entering the well above the shale. In any case, water in contact with the shale is generally. a hydrogen sulfide-type water, often containing natural gas. As most domestic wells can be developed with satisfactory results above the Chattanooga Shale, the occasion for exploration below the shale has been limited, expecially where the Chattanooga occurs at depths of 50 feet or more in the plains area away from the hillsides. 


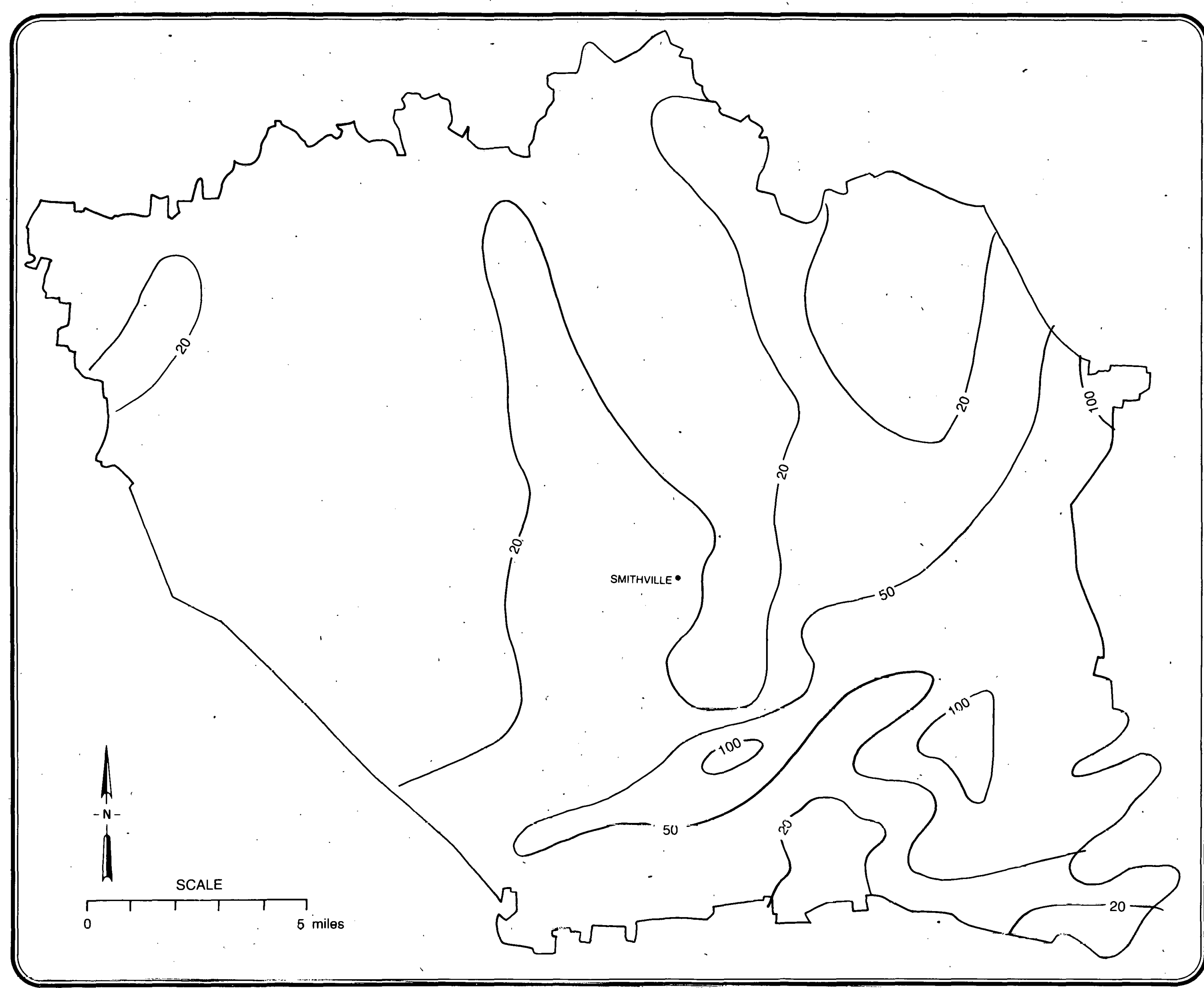

ISO-SOIL MAP

OF DEKALB COUNTY

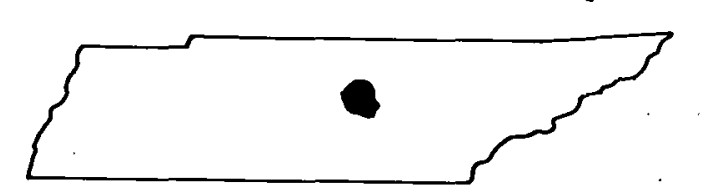

KEY

Contours show thickness of soil above limestone bedrock. All contours

approximately located. Control

(Adapted from Moore-Wilson 1972.)

FIGURE $\quad X-3$ 
While not much information is available on groundwater occurrences in the Leipers-Catheys formations at depths of 100 feet to several hundred feet below the surface, indications are that these deeper formations do not yield adequate quantities of water for household needs.

Reported in Wilson, et al. [1972] are the following findings regarding water well yields in DeKalb County. During the period 1963 to 1972,469 water wells were drilled and relative information filed with the State by water well contractors. The yield to 81.7 percent of these wells was more than $3 \mathrm{gpm}$ (gallons per minute), and 38.5 percent of the wells yielded more than $10 \mathrm{gpm}$. The yield to 6.5 percent was more than 25 $\mathrm{gpm}$, and 0.8 percent ( 4 wells) reportedly yielded in excess of $100 \mathrm{gpm}$. The average specific capacity of 123 selected wells was 0.60 ; the average well depth was 111 feet. Water well yield distributions in DeKalb County are depicted in Figure $\mathrm{X}-4$.

\section{Water Resources Development}

Strategies for surface water resource development which have evolved in central Tennessee have been oriented toward generating hydroelectric power, controlling devastation from flooding, and acquiring source water for industrial and domestic use.

\section{Tennessee Valley Authority}

Much of the Chattanooga Shale country of the east-central United States lies within the area administered by the Tennessee Valley Authority (TVA). This agency of the Federal Government, established in 1933, manages natural resources in the valley of the Tennessee River. Soil and water conservation, river development, rural electrification, flood damage prevention, and fertilizer and agricultural development are among the objectives which have received the major emphasis of TVA activity.

To facilitate unified resource development, TVA has designed a multipurpose water management system which presently includes nine large dams on the main-steil Tennessee River, and other dams on the principal tributary 


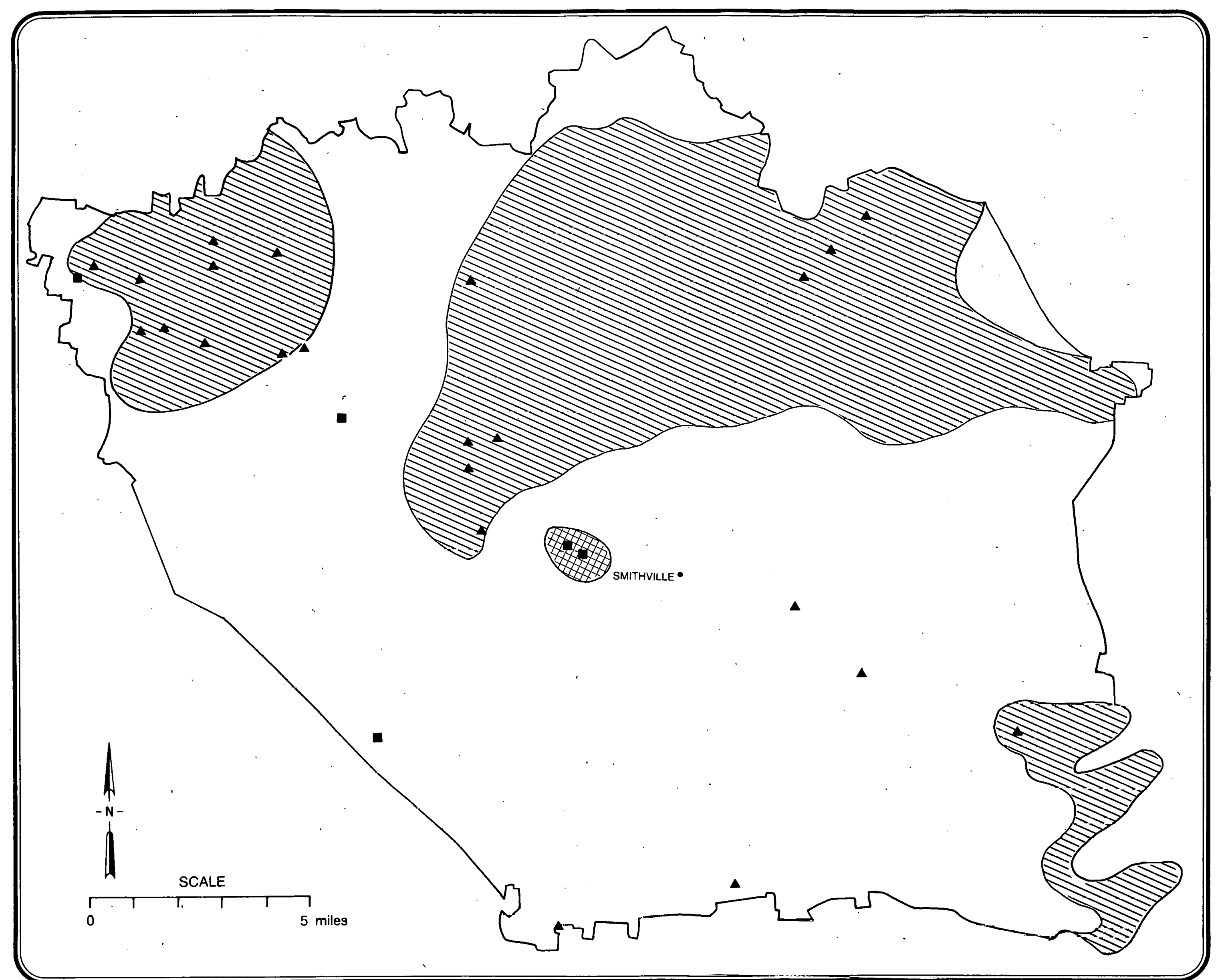

WATER WELL YIELDS IN DEKALB COUNTY

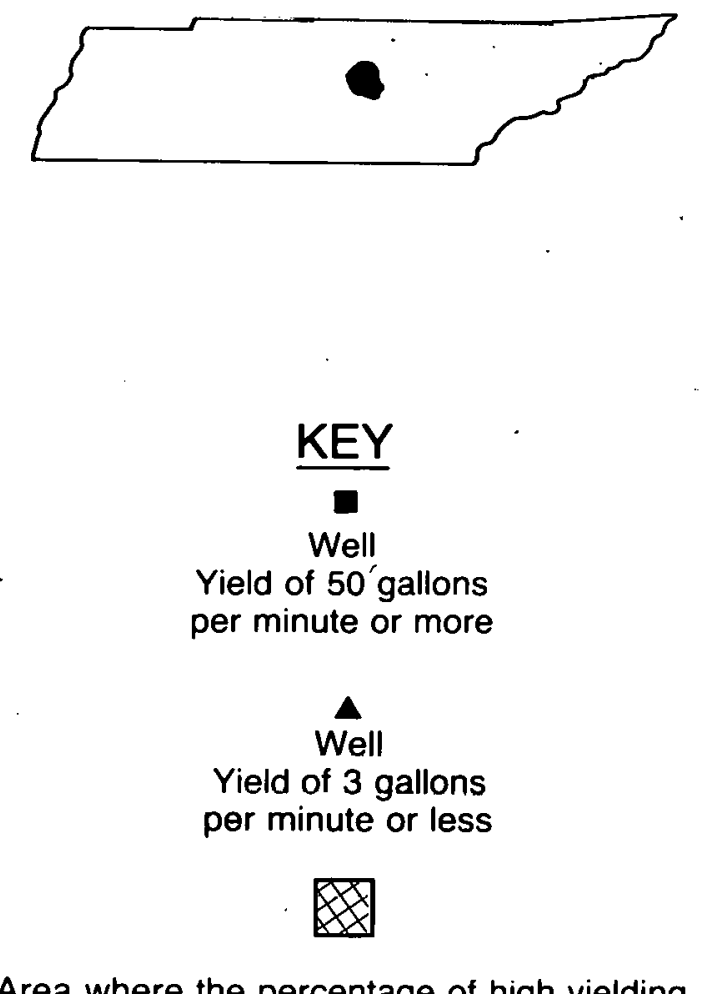
wells is much larger than average

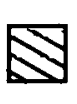

Area where the percentage of low yieldin wells is much larger than average

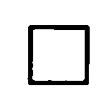

Average area where most wells yield from 4 to 49 gallons per minute

FIGURE X-4 
streams. Commercial navigation has been made a reality by a waterway system which maintains a minimum navigation depth of 11 feet along the entire 650-mile length of the Tennessee. The disastrous flooding of the major streams of the region has been greatly mitigated by operation of the TVA dam and reservoir system.

\section{Community Water Service}

From 1963 until 1972, 469 private water wells were reported drilled in DeKalb County. Of these, no doubt many have been abandoned since the advent of central water services to many rural areas. Of course, new wells have also been drilled in the past 5 years, perhaps as many as 100 to 150 , where central water is not available. No records are available for water wells drilled prior to 1963, when the State of Tennessee began its program of data collection from water wells, nor are there any records to show the number of private springs used. However, the use of private springs is known to be minimal compared with the use of private water well systems.

Of the approximate 6,800 population [W.H. Thaxton, Director of Community Development - Personal Communication] in the rural area, 4,200 have access to central water services from the DeKalb Utility District. of the 2,600 residents outside the limits of central water, many live to. . the north and south of Dowelltown in the basin area of the county, outside the project area for uranium mining. The need for private water wells continues in the areas not covered by central water services from the DeKalb Utility Diatrict.

By the summer of 1978 , central water services will be available to 65 persent of the rural population. Of the 12,000 residents in the county, only 2,380 will be dependent upon private water systems. Indications are that the 800 residents served by the Dowelltown-Liberty central water system, which uses groundwater, will be absorbed by the DeKalb Utility District and supplied water from the City of Smithville. It is also likely that the DeKalb Utility District will be in a position to Eupplement or supply needs of the Alexandria water system whose 1,000 residents are served by Smith County district water. 
The capacity of the Smithville water plant will soon be doubled to 2 million gallons per day (mgd) making it possible to serve the total county population of 12,000 persons. The source of the Smithville water supply is Center Hill Lake and the intake is at Sligo Bridge. The raw water quality is excellent, and the upgrading of the filtration plant and mains will further enhance the water services provided by the Smithville system.

In addition to central water supplied by the City of Smithville, Liberty, Dowelitown; and Alexandria, all of DeKalb County east of the Caney Fork River (Center Hill Reservoir) is supplied by water from the De-White Utility District in White County. This district is supplied by the City of Sparta whose system is being expanded to a capacity of $3 \mathrm{mgd}$ from its present 2 mgd capacity.

Community water supply systems and associated water quality in DeKalb and surrounding counties are enumerated in Appendix D. The central water service system of DeKalb County is depicted in Figure $X-5$.

\section{Surface Water Quality}

The surface waters in the Upper Cumberland River basin have a natural quality capable of supporting all designated stream uses [Tennessee Department of Public Health 1976]. No naturally occurring major pollution problems are known to exist in the basin. Where it exists, water quality impairment is man-induced.

Table X-2 summarizes surface water quality in the regional area of Center Hill Lake.

\section{Center Hill Reservoir Water Quality}

At a pool elevation of 685 feet, the lake contains over 2 million acre-feet of water, of which nearly 1 million acre-feet is dead storage. Using a median pool elevation of 650 feet, the top of the Chattanooga formation is generally 200 to 300 feet above the level of the lake. 


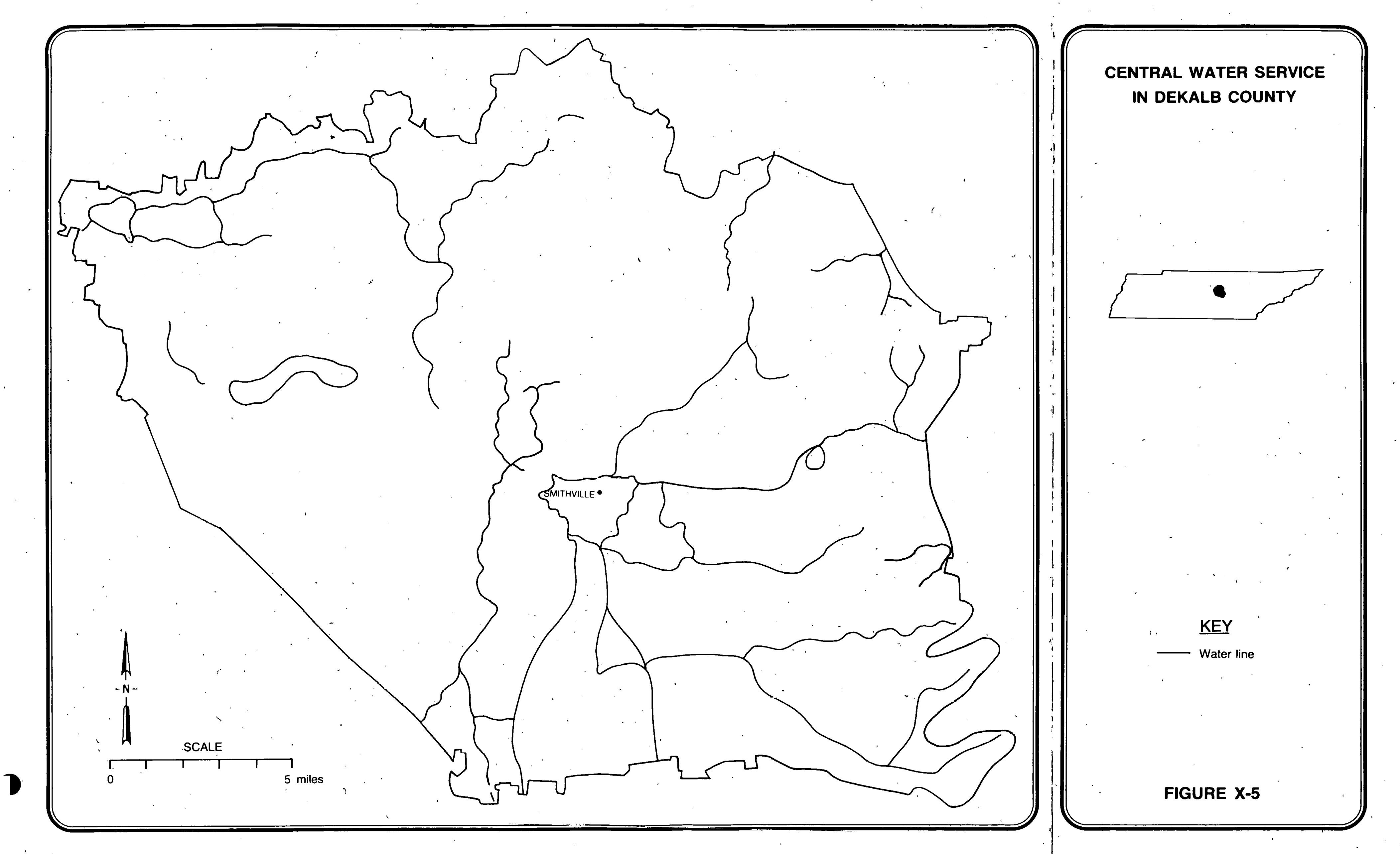


'ABLE X-2. SURFACE WATER QUALITY - CENTER HILL LAKE REGION [a]

\begin{tabular}{|c|c|c|c|c|c|c|c|c|}
\hline $\begin{array}{l}\text { Station } \\
\text { Number }\end{array}$ & $\begin{array}{c}\text { Station } \\
\text { Name }\end{array}$ & $\begin{array}{l}\text { Iron } \\
(\mathrm{Fe})\end{array}$ & $\begin{array}{l}\text { Sulfate } \\
\left(\mathrm{SO}_{4}\right)\end{array}$ & $\begin{array}{r}\text { Chloride } \\
(\mathrm{Cl})[\mathrm{c}]\end{array}$ & $\begin{array}{l}\text { Dissolved } \\
\text { Solids [d] }\end{array}$ & $\begin{array}{r}\text { Hardness } \\
\left(\mathrm{CaCO}_{3}\right)\end{array}$ & $\mathrm{pH}$ & $\begin{array}{l}\text { Turbidisy } \\
\text { [c] }\end{array}$ \\
\hline 1 & $\begin{array}{l}\text { Cane Creek near } \\
\text { Boiling Springs }\end{array}$ & 0.32 & 9 & 8 & 205 & 125 & 8.2 & 7 \\
\hline 2 & $\begin{array}{l}\text { Cane Creek near } \\
\text { Cookeville }\end{array}$ & 020 & 7 & 10 & 225 & 140 & 8.1 & 5 \\
\hline 5 & $\begin{array}{l}\text { Clear Fork Creek } \\
\text { near Liberty }\end{array}$ & 0.02 & 13 & 10 & 300 & 150 & 7.8 & 0 \\
\hline 6 & $\begin{array}{l}\text { Dry Creek at } \\
\text { Dowelltown }\end{array}$ & 1.3 & 15 & 5 & - & 95 & 8.0 & 4 \\
\hline 7. & $\begin{array}{l}\text { Falling Water } \\
\text { River near Algood }\end{array}$ & 0.00 & 4 & - & 300 & 140 & 7.6 & - \\
\hline 8 & $\begin{array}{l}\text { Falling Water River } \\
\text { near Cookeville }\end{array}$ & 0.20 & 30 & 10 & 415 & 175 & 8.0 & - \\
\hline 9 & $\begin{array}{l}\text { Helton Creek near } \\
\text { Temperance } \mathrm{Hall}\end{array}$ & 0.02 & 15 & 15 & 330 & 200 & 8.0 & 15 \\
\hline 10 & $\begin{array}{l}\text { Hickman Creek at } \\
\text { Carthage Junction }\end{array}$ & 0.12 & 30 & 20 & 405 & 220 & 7.8 & - \\
\hline 11 & $\begin{array}{l}\text { Hickman Creek } \\
\text { near Alexandria }\end{array}$ & 0.05 & 18 & 10 & 435 & 220 & 7.9 & 10 \\
\hline 12 & $\begin{array}{l}\text { Hudgens Creek } \\
\text { near Cookeville }\end{array}$ & 0.35 & 10 & 5 & 305 & 150 & 8.1 & 5 \\
\hline 13 & $\begin{array}{l}\text { llurricanc Crcck } \\
\text { near Auburntown }\end{array}$ & 0.09 & 18 & 5 & 320 & 155 & 8.0 & 0 \\
\hline 14 & $\begin{array}{l}\text { Indian Creek at } \\
\text { Buffalo Valley }\end{array}$ & 0.08 & 8 & - & 175 & 135 & 8.0 & - \\
\hline 15 & $\begin{array}{l}\text { Mulherrin Creek } \\
\text { near Gordonsville }\end{array}$ & 0.10 & 25 & 15 & 390 & 195 & 8.0 & 10 \\
\hline 16 & $\begin{array}{l}\text { Pigeon Roost Creck } \\
\text { near Cookeville }\end{array}$ & 0.05 & 18 & 15 & 460 & 195 & 7.1 & 0 \\
\hline 17 & $\begin{array}{l}\text { Pine Creek near } \\
\text { Keltonburg }\end{array}$ & 0.02 & 10 & 5 & 125 & 85 & 7.6 & 0 \\
\hline
\end{tabular}


TABLE.X-2. (Continued)

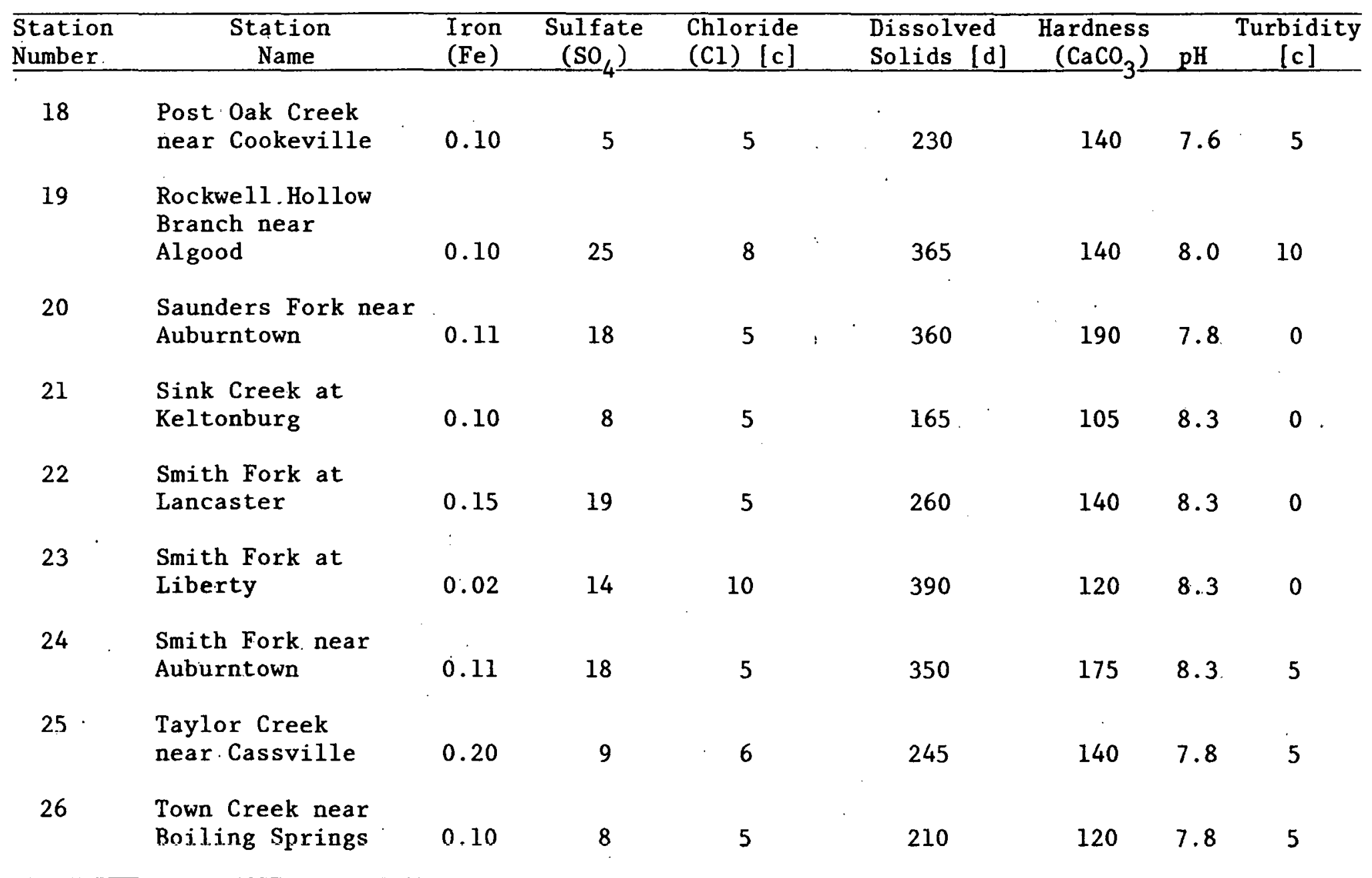

[a] 'Moore and Wilson [1972].

[b] $\mathrm{H}=$ Highland Rim; $\mathrm{B}=$ Central Basin; $\mathrm{P}=$ Cumberland Plateau

[c] Median from three samples

[d] Specific conductance at $25^{\circ} \mathrm{C}$, read as milligrams per liter $\mathrm{NaCl}$ and multiplied by 1.74. Approximately equal to dissolved solids as milligrams per liter $\mathrm{CaCO}_{3}$. Median from three or four samples. 
This difference in elevation, while physically separating the shale from the limestone environment in which the lake lies, does enable groundwaters and spring waters to flow from the mining area to the lake. The Chattanooga outcrops are usually 1,500 feet or more in linear distance from the lake.

The U.S. Army Corps of Engineers recently investigated the quality of Center Hill Reservoir [U.S. Army Corps of Engineers 1976]. The summary and conclusions of this study have been referenced:by the Water Quality Management Plan prepared for the Upper Cumberland River basin [Tennessee Department of Public Health 1976]. Highlights of the Corps report are quoted as follows:

- Center Hill Reservoir is a deep, temperature-density stratified reservoir with long hydraulic residence times during the March through November stratification period. No complicated stratified flow conditions were found.

- The reservoir trophic state evaluations based upon phosphorus, nitrogen, dissolved oxygen and hydraulics showed that Center Hill ranks as a eutrophic reservoir.

- Dissolved oxygen in the Center Hill hypolimnion is being depleted to the danger level. This depletion is most serious in the metalimnion and benthic zones. Studies should be conducted to determine the causes of severe depletion in the metalimnion at the earliest opportunity.

- Nitrogen and phosphorus concentrations in Center Hill are considerably in excess of those desirable. Sources and fates of these nutrients should be determined by future studies.

- Iron and manganese concentrations are well below problem levels, both in the reservoir and its tailrace stream, at the present time.

- The water in Center Hill Reservoir is generally suitable as a high quality water supply source although the Cookeville Water Treatment Plant experiences high levels of coliforms and algae.

- Plankton and benthos studies are needed for Center Hill Reservoir.

- A fine sport fishery now exists for the lake and tailrace stream. However, the possibility that low dissolved oxygen concentrations and heavy sport fishing pressures are affecting the fishery should be addressed. 
- Further water quality studies will be required to develop the alternatives for a comprehensive water quality management plan for Center Hill Reservoir.

Groundwater Quality

Most of the rocks overlying the Chattanooga Shale are limestone with calcium carbonate as the dominant chemical constituent. Water acts as a solvent on the water-bearing openings in the limestone, and the quality of the groundwater is affected by this dissolving action. The typical water from limestone is slightly alkaline and moderately to very hard.

The State of Tennessee has surveyed selected wells in DeKalb County. Resulting data representative of the chemical quality of groundwater are highlighted herein. Averages for selected constituents were as follows: $\mathrm{pH}-7$; iron - $0.18 \mathrm{ppm}$; sulfate - $51 \mathrm{ppm}$; sodium chloride - $143 \mathrm{ppm}$; total hardness - 183 ppm; silica - 8 ppm; alkalinity - 186 ppm; total dissolved solids - $442 \mathrm{ppm}$; and water temperature - $59 \mathrm{~F}$.

These data included well completions in the basin area of the county in addition to the rim area; therefore the results are somewhat misleading in terms of an evaluation of Highland Rim groundwater. The sulfate content appears to be high, iron content appears to be low, and the sodium chloride concentration is much too high. These excesses contribute to a dissolved solids content which is also higher than would be expected for water occurring in the soils and bedrock aquifer of the rim country.

Another report, [Moore and Wilson 1972] provides information on 280 Highland Rim water wells which were tested for selected chemical quality. These results appear to be more representative of Highland Rim groundwater than the results from the previous report. Based upon a 90 percentile factor, average water qualities reported are: iron - $0.3 \mathrm{ppm}$; sulfate - $28 \mathrm{ppm}$; chloride - $38 \mathrm{ppm}$; hardness - $250 \mathrm{ppm}$; and $\mathrm{pH}-7.5$. Other results of this report indicate that 87 percent of DeKalb County wells contain no hydrogen sulfide water or noticeable amounts of iron, gas, oil, salt, and other undesirable constituents. 
In terms of bacteriological water quality the State report is limited to 20 samples which is not necessarily a representative sample. Based upon a criterion of 5 coliform colonies per $100 \mathrm{ml}$, 70 percent of the samples were found to have good water quality. The failure of 30 percent of the samples to satisfy the bacterial criterion is possibly due to poor sampling techniques.

The chemical quality of groundwater is generally acceptable for potable uses. The bacteriological quality of the water is likely to be satisfactory where wells are constructed properly and protected.

In the course of a groundwater survey conducted in 1965-66 by the Division of Water Quality Control [Tennessee Department of Health 1976], selected wells and springs supplying the community of Smithville, DeKalb County, were sampled monthly for 12 months. Resulting data are summarized in Table $\mathrm{X}-3$.

Water in contact with the Chattanooga Shale generally contains dissolved hydrogen sulfide and natural gas. In the DeKalb County area the aquifer system above the Chattanooga Shale is deep enough that domestic wells develop sufficient water without penetrating to the area containing the poorer quality water. In some other areas, the Chattanooga occurs at shallow depth and water wells are sometimes developed in the lower Fort Payne aquifer immediately above the shale. In these cases the interchange of poorer quality water from the Chattanooga Shale with better quality from the Fort Payne Formation is a possibility that must be considered.

As noted earlier, little information is available regarding groundwater occurrence in the Leipers-Catheys Formation at depths 100 feet to several hundred feet below the surface. There are indications that water percolating through the relatively impervious Chattanooga Shale imparts objectionable sulfurous chemical species which could prohibit the direct potable usage of the water unless it were treated. 
TABLE X-3. CHEMICAL QUALITY OF SELÉCTED WELLS AND SPRINGS [a]

\begin{tabular}{lccc}
\hline \multicolumn{1}{c}{ Constituent } & $\begin{array}{c}\text { Smithville } \\
\text { (DeKalb County) }\end{array}$ & $\begin{array}{c}\text { Caney Fork } \\
\text { Wells }\end{array}$ & $\begin{array}{c}\text { Caney Fork } \\
\text { Springs }\end{array}$ \\
\hline Alkalinity as $\mathrm{CaCO}_{3}(\mathrm{mg} / 1)$ & 72 & 178 & 130 \\
Hardness as CaCo ${ }_{3}(\mathrm{mg} / 1)$ & 96 & 145 & 137 \\
pH & 7.5 & 6.9 & 7.4 \\
Turbidity (mg/1) & 1 & - & - \\
Apparent Color $(\mathrm{mg} / 1)$ & 6 & - & - \\
Calcium as CaCO (mg/1) & 59 & - & - \\
Chloride (mg/1) & 4 & - & - \\
Fluoride (mg/1) & 0.1 & 0.20 & 0.08 \\
Iron (mg/1) & 0.1 & - & - \\
Manganese (mg/1) & 0.0 & 36 & 17 \\
Sulfate (mg/1) & 5 & & \\
\hline
\end{tabular}

[a] Data from Tennessee Department of Health, 1965-66. 


\section{ANALYSIS OF IMPACTS}

The following analysis of projected impacts upon water resources from production of Chattanooga Shale uranium considers effects derived from two major activity sources: shale extraction and shale processing. Liquid wastes expected to be generated by the process scheme are characterized and methods for disposal are discussed.

\section{ORE EXTRACTION}

The plan of mine development and the extraction techniques employed during the mining operation will affect the nature of surrounding aquifers. Present indications are that ore removal is to advance down-dip and will include removal of the overlying Maury Formation which lacks the strength to be used as the mine roof. The bottom of the Fort Payne Limestone formation thus will be exposed to form the mine roof. Since this formation contains solution cavities and fractures, it is probable that the Fort Payne groundwater table will be lowered as water escapes from the formation into the mine. The possibility exists that the Fort Payne formation might be totally dewatered in extensively fractured areas overlying the mine.

An approximation of the quantity of water in storage in the formations above the Chattanooga Shale can be derived by making certain assumptions as follows: if 20 feet of saturation exist in the residuum with a porosity of 15 percent, and 100 feet of saturation exist in the Fort Payne formation with a pornsity of 1 percent, the quantity of water contained in 1 acre over the mine would amount to 4 acre-feet, or 1.3 million gallons. An approximation of the annual quantity of water that could infiltrate into the mine after initial dewatering through extensively fractured portions of the Fort Payne formation would be the water infiltrating below the root zone. This quantity could be on the order of 1 acre-foot per acre, or 3 million gallons per acre, per year. 
Since there will be no natural drainage from the mine, it will be necessary to pump all groundwater inflow from the lowest headings. The mine pumping system is to be designed to handle an average inflow of 5,000 gallons per minute over the entire mine.

The room and pillar mining scheme proposed for use will remove a 16 -foot thickness of the Chattanooga which in DeKalb County averages about 32 feet thick. A substantial thickness of the lower Dowelltown Member of the Chattanooga, which is considered to be relatively impermeable, will generally therefore remain underlying the mine. The thickness of the Chattanooga is variable, however, so there is the possibility that the underlying limestone formation may be exposed, leaving relatively pervious areas on the mine floor. Fractures will also be present which will permit water to flow from the mine areas.

\section{PROCESS WASTEWATER STREAMS}

The following analysis and discussion of project-generated waste streams and their potential environmental effects is based upon projected compositions of waste streams. The two major process sources of waste streams are hydroretoring to recover shale oil and leaching to recover shale uranium. Within the scheme of the projected mining/processing operational plan, the ultimate destination of these wastes will be either stream discharge, or tailings storage in both disposal ponds and.backfilled mines. The recommended process train has not been piloted and no data exist regarding composition of process streams. The compositions of the process streams and the wastewaters generated are projected from the vast documentation of existing pilot facilities for processing western U.S. oil shale. It is recognized that the hydroretorting process will produce wastewaters of different compositions than those produced by conventional retorting operations. However, it is probable that the wastewater streams produced by the different retorting processes will be similar. 
There is no direct information available regarding the composition of the leachates emanating from the neutralized tailings. The general nature of these waste streams can be projected from the composition documented for western U.S. shale oil tailings and the process wastes of the Ranstad Plant (described in Section IV) which does not retort ores prior to uranium leaching.

A schematic flowsheet of the anticipated major waste stream-generating operations is illustrated in Figure X-6. For the purposes of this preliminary evaluation it is assumed that other minor wastewaters such as domestic wastes, gas scrubber blow down, cooling tower blowdown, etc., can be treated and disposed with one or more of the major streams, and/or will not pose significant treatment/disposal problems.

\section{Retort Water}

The hydroretorting process produces a liquid waste stream which contains large amounts of dissolved organics and inorganics. The composition of the retort water is affected by the composition of the ore and the design and operational characteristics of the retort.

\section{Volume}

Table X-4 presents average compositions of eastern and western shales. The data indicate that the eastern shales yield almost 50 percent more water than western shales currently under evaluation. A water yield of 2.3 percent by weight produces 5.5 gallons per ton of ore. A 100,000 ton per day facility would generate in excess of 0.5 million gallons per day. This flowrate could be greater if significant quantities of water are used in dust control operations preceeding retorting.

\section{Composition}

The general composition of western shale retort waters is presented in Tables $X-5, X-6$, and $X-7$. The water is collected as condensate from the off-gas stream and contains large quantities of both volatile inorganic 


\section{SOURCES OF MAJOR PROCESS WASTE STREAMS}

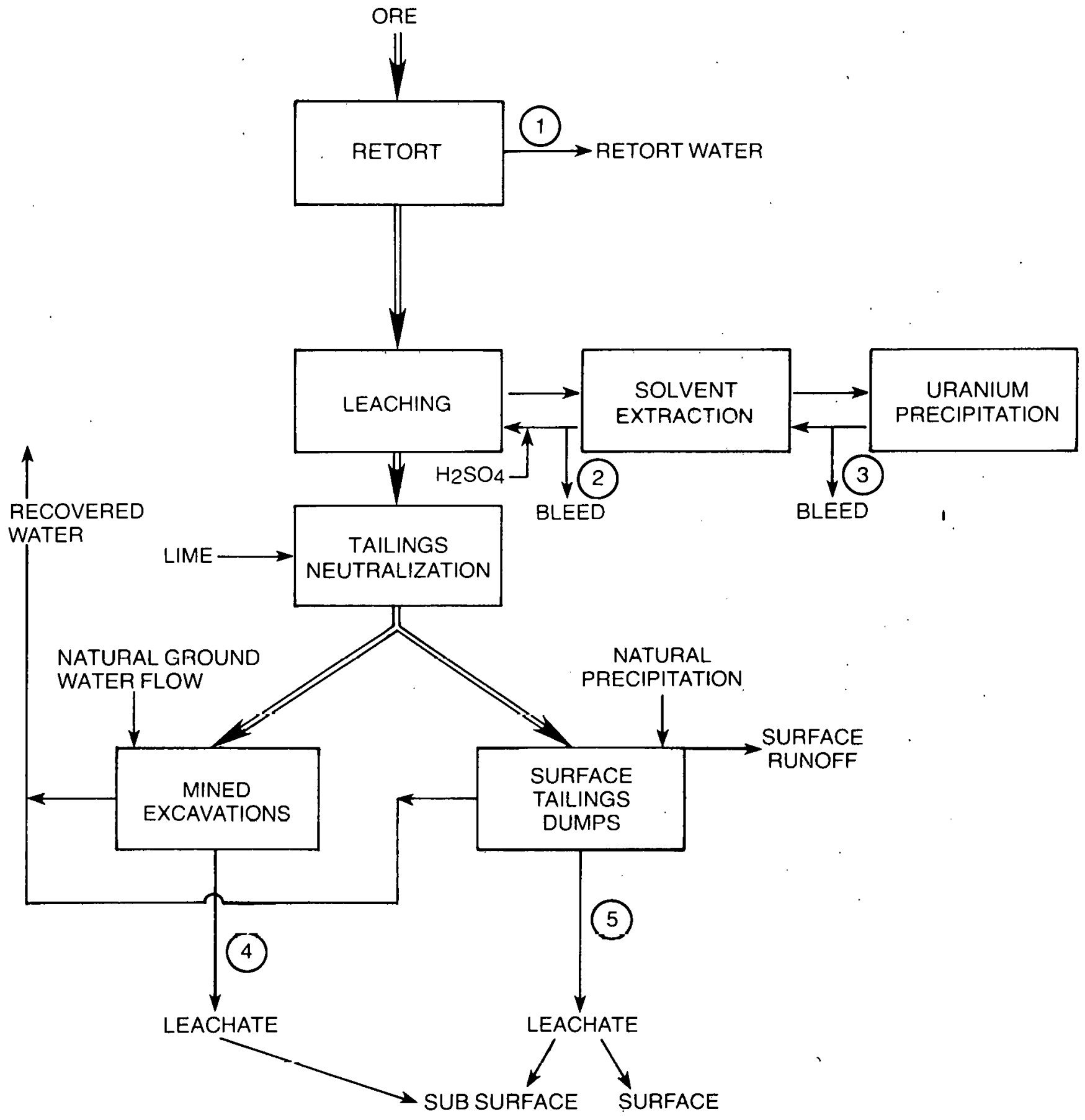

FIGURE X-6 
TABLE X-4. COMPOSITION OF EASTERN AND WESTERN SHALES

Eastern Western

Ultimate Analysis, wt \% (dry basis)

Organic Carbon Hydrogen

Sulfur

Carbon Dioxide

Ash
13.7

1.6

4.7

0.5

78.3
13.6

2.1

0.5

15.9

66.8

Fischer Assay Analysis

Oil yield, wt \% Water Yield, wt \%

Loss + gas, wt \%

4.6

2.3

2.4

10.3

11.4

1.6

2.6

Assay, gal/ton

29.8 
TABLE X-5. ALKANOIC ACIDS IN ORGANIC FRACTION RETORT WATER [a]

\begin{tabular}{lc}
\hline \multicolumn{1}{c}{ Acid } & Weight \% [b] \\
\hline Acetic & 1 \\
Propionic & 9 \\
Butyric & 11 \\
Valeric & 20 \\
Caproic & 21 \\
Denanthic & 13 \\
Caprylic & 7 \\
Isomeric and Unidentified $\quad$ & \\
$\quad$ Carboxylic acids & 18 \\
\hline
\end{tabular}

[a] Source: Cook [1971].

[b] Totals $100 \mathrm{mg}$ acids per $\mathrm{kg}$ feed shale 
TABLE X-6. COMPONENTS OF THREE OIL SHALE WASTE WATERS [a]

\begin{tabular}{lccc}
\hline \multicolumn{1}{c}{ Components } & Water $1[\mathrm{a}]$ & Water $2[\mathrm{c}]$ & Water 3 [d] \\
\hline Ammonia & 12.4 & 4.8 & 2.4 \\
Sodium & 1.0 & 3.1 & 0.5 \\
Carbonate & 14.4 & 19.2 & 20.8 \\
Carbon, total & 18.5 & 6.4 & 6.7 \\
Chloride & 5.4 & 13.4 & 1.8 \\
Nitrate & Trace & Trace & Trace \\
Nitrogen, Total & 10.2 & 5.4 & 3.0 \\
Sulfate & 3.1 & 4.5 & 1.2 \\
Sulfur, nonsulfate & 1.9 & 0.3 & 1.0 \\
& & & \\
\hline
\end{tabular}

[a] Source: Cook [1971]

[b] Separated from gas combustion retort oil

[c] Separated from an oil produced by in-situ retorting

[d] Separated from an oil produced in a 150-ton batch retort 
TABLE $X-7$. SUMMARY OF CHEMICAL ANALYSES PERFORMED BY VARIOUS ANALYSTS ON RETORT WATER FROM LARAMIE ENERGY

RESEARCH CENTER 150-TON AND 10-TON RETORTS

\begin{tabular}{|c|c|c|c|c|}
\hline Constituent & $\underset{\ldots}{\mathrm{T} . \mathrm{F}}$. Yen & $\begin{array}{l}\text { a] } \\
\text { 非 }\end{array}$ & $\begin{array}{l}\text { Accu- } \\
\text { Lab [a] }\end{array}$ & $\begin{array}{l}\text { University } \\
\text { of } \\
\text { Colorado [b] }\end{array}$ \\
\hline Chemical Oxygen Demand & 20,000 & 12,500 & - & 11,100 \\
\hline Total Organic Carbon & 3,182 & 19,000 & - & 5,379 \\
\hline Biological Oxygen Demand & 5,500 & 350 & - & - \\
\hline Inorganic Carbon (mg/l-c) & 3,148 & 826 & - & 6,248 \\
\hline Total Residue & 30,100 & - & - & 39,920 \\
\hline Non-Filterable Residue & - & - & - & 209 \\
\hline $\mathrm{NH}_{3}$ & 4,790 & - & - & 1,400 \\
\hline $\mathrm{NH}_{4}^{7}$ & - & - & - & 8,286 \\
\hline Organic-N & 1,510 & - & - & 733 \\
\hline $\mathrm{Cl}^{-}$ & - & 1,560 & 11 & 1,843 \\
\hline $\mathrm{SO}_{4}^{=}$ & 59 & 930 & - & 1,176 \\
\hline $\mathrm{K}^{++}$ & 3.5 & - & 33 & 805 \\
\hline $\mathrm{Na}^{+}$ & 312 & - & 500 & 446 \\
\hline $\mathrm{Mg}^{++}$ & 48.4 & 16.4 & 14 & 10.7 \\
\hline $\mathrm{Ca}^{++}$ & 14.9 & 4.6 & 6.3 & 10.3 \\
\hline $\mathrm{PO}_{4}=$ & 0.26 & 19.0 & 0.31 & 0.23 \\
\hline $\mathrm{Cu}^{++}$ & 5.6 & 0.94 & 0.008 & 0.90 \\
\hline Phenols & 169 & 2.2 & - & 8.5 \\
\hline$I^{=}$ & 0.003 & 1.3 & - & - \\
\hline $\mathrm{Br}^{-}$ & 0.46 & 0.01 & - & - \\
\hline$s=$ & 16.1 & 15.4 & - & - \\
\hline $\mathrm{Fe}$ & 3.3 & 3.75 & 0.09 & - \\
\hline $\mathrm{Zn}^{++}$ & 1.6 & 2.8 & 0.06 & - \\
\hline $\mathrm{NO}_{3}^{-}$ & 38 & - & - & - \\
\hline $\mathrm{SiO}_{2}$ & - & 78.3 & 17 & - \\
\hline Oil and Grease & - & - & - & 3,836 \\
\hline $\mathrm{HCO}_{3}^{-}$ & - & - & - & 34,000 \\
\hline
\end{tabular}

[a] Data are from Linstedt, et al. [1976]

[b] Data are from UC-Lawrence Berkeley Laboratory Report [1977] 
and organic species. Since the liquid phase does not generally come in direct contact with the shale residue, many soluble salts remain in the retorted shale.

The waters characteristically exhibit a total solids concentration in the range of 20,000 to $30,000 \mathrm{mg} / 1$ with significant amounts of ammonia, chloride, sulfate, and sodium (500 to $2,000 \mathrm{mg} / 1)$. The primary constituent of the waters is the organics which result in extremely high COD values $(10,000$ to $20,000 \mathrm{mg} / 1)$. Such wastewaters are considered heavily contaminated and require significant treatment prior to discharge.

The majority of trace metals will probably remain in the retorted shale. In recent studies using western shales and a nitrogen gas retort atmosphere, Shendrikar and Faudel [1978] found that only fluoride, boron, and copper could be detected in retort water at concentrations in the range of 0.2 to $0.5 \mathrm{mg} / 1$. Chromium, cobalt, manganese, molybdenum, nickel, selenium; and zinc were found in the retort water at concentrations less than $0.1 \mathrm{mg} / 1$. The composition of the retort water generated by the proposed process will differ from that studied by Shendrikar and Faudel because of the presence of a hydrogen retort atmosphere. Certain metals such as antimony and arsenic can form gaseous hydrides which would be present in the retort condensate.

Significant amounts of sulfur occur in the eastern oil shales. Table X-4 indicates that approximately 4.7 percent sulfur is initially present. The proposed processing operations will convert the sulfur compounds to $\mathrm{H}_{2} \mathrm{~S}$ and elemental sulfur which will be used to produce sulfuric acid for uranium leaching. It is possible that significant amounts of $\mathrm{H}_{2} \mathrm{~S}$ could be present in the retort water. If conventional retorting is utilized instead of hydroretorting, the resulting sulfate concentration can be projected by extrapolation of the data in Tables $X-4$ and $X-6$. The eastern ores contain approximately ten times the sulfur content of the western shales. The sulfate in the retort water of western shales ranges from 1,200 to $3,100 \mathrm{mg} / 1$. It is probable that eastern shales would result in concentrations several times these levels. 
No estimate or projection is presented regarding the occurrence of radioactive constituents in the retort water. Intensive laboratory and pilot scale demonstration studies are required for quantification of the nature of the retort water in this respect.

\section{Toxicity}

The retort waters will contain significant quantities of several highly toxic substances. The waters will have to either undergo significant treatment prior to release to the environment or be diluted and treated with other waste streams. While volume of retort water will be only approximately 2 to 4 percent of the total water used in a 100,000 ton/day processing plant, it contains a substantial portion of all contaminants generated.

\section{Leachates}

As illustrated in Figure X-6 leachate can be generated both from the backfilled mines and the tailings disposal ponds, flows 4 and 5 , respectively. The nature of the leachates and their volumes are dependent upon many site specific factors such as physical characteristics of the surrounding geologic formations, the waste tailings treatment process, and the chemical nature of percolating water. The following discussion is based upon results reported for projects similar to the one under consideration herein since the proposed beneficiation process flow scheme for the latter has not been piloted. The leachates from both potential sources will be discussed simultaneously because of their similarity.

\section{Volume}

It is impossible to predict in more than a general fashion the volumes of leachate from either source because of the many unknown site specific factors involved. The detailed hydrologic investigations that would be required for preparation of a site specific required environmental report would quantify leachate volumes in detail. 
Conventional, unlined tailings disposal ponds with facilities for diversion of surface runoff will produce approximately 0.6 to $1.2 \mathrm{gpm}$ per acre of tailings. This flowrate range is based upon an assumed net surface infiltration rate of 12 to 24 inches per year. The majority of precipitation is assumed to be returned directly to the atmosphere via evapotranspiration. The hypothesized 800 acres of tailings ponds produced during the 20-year life of a 100,000 ton per day complex will result in approximately 500 to $1,000 \mathrm{gpm}$ of leachate. With a disposal pond depth of 100 feet and a porosity of 0.35 , approximately 17 to 35 years will be required for flushing a single pore volume from the waste tailings. Therefore, if it is assumed that 5 to 10 pore volumes must be flushed through the waste materials to leach out all objectionable substances, then unacceptable leachate will be produced for a period of 85 to 350 years. During this time it will be necessary to recycle wastewaters to mining operations in the area or to treat them by leachate treatment plants.

The volume of leachate produced from the backfilled mines depends upon the following factors: 1) permeability and recharge of overburden; 2) permeability of backfilled tailings; 3) permeability of underlying formations; 4) effectiveness of underdrain system. The great depth of fractured overlying limestone makes it impossible to estimate the amount of water expected to percolate into the mined areas. Solution cavities in the limestone can transport large quantities of water from great distances. The magnitude of the maximum mine infiltration will be determined during the room and pillar mining operatiuns.

\section{Composition}

While the composition of the leachate is affected by many factors, it is most highly dependent upon the nature of the process to neutralize the acid-leached residue. The leached residue is highly acidic and contains many soluble species including toxic trace metals. The proposed scheme for de-acidifying the residue employs a lime neutralization process 
subsequent to acid leaching. Proper selection of lime dosage will result in neutral-to-slightly alkaline conditions occurring in the tailings disposal areas.

Studies by IGT (unpublished) indicate that approximately'16 to 20 percent of the organics originally present in the shale will remain in the spent shale. Organics will therefore represent approximately 1 percent of the spent shale. If these organics are biodegradable directly or at the dilute levels occuring in leachate, anoxic or anerobic conditions should exist. It is possible, however, that the residual organics will be non-biodegradable and therefore will not remove the dissolved oxygen in any percolate. While this is improbable in view of the nature of waters -percolating through the natural oil shale, it does suggest that laboratory studies be performed to better define the nature of the leached, limetreated residues.

In addition to organics, the leachate will contain a spectrum of inorganics. Table $X-8$ presents the composition of moisture in the lime-treated tailings of the Ranstad operation. The effects of the acid and subsequent lime treatment are apparent. Although carbonate/bicarbonate are not reported, their concentrations would be low due to their removal as carbon dioxide during the acid leaching. The primary input of sulfate is by the sulfuric acid leaching; the source of calcium is the lime treatment process. The composition of the Ranstad leached waste residue prior to lime treatment is presented to enable the reader to evaluate the effectiveness of the lime neutralization process.

It is obvious that the Ranstad residue shale is rich'in organic carbon due to the lack of oil recovery processing. The Ranstad tailings are composed primarily of silica, organic carbon, potassium, iron, aluminum, and sulfur. In general these substances do not cause environmental problems and do not exhibit toxicity. The toxic trace substances present, such as the mercury, lead, chromium, etc., while occurring at low levels, are capable of being solubilized and transported into the surrourding environment. 
TABLE X-8. COMPOSITION OF LIME-TREATED LEACH RESIDUE MOISTURE AT RANSTAD

Constituent $\quad$ Concentration (mg/1)

Major Constituents

Potassium 60

Calcium 560

Magnesium

40

Ammonia

8

Sodium

5

Sulfate

1300

Minor Constituents

Aluminum

0.3

Iron

1.0

Molybdenum

10.0

Chromium

0.005

Nickel

0.1

Copper

0.03

Manganese

2.5

Zinc

Uranium

0.3

0.6

Arsenic

0.02

Lead

0.02

Tin

0.001

Cadmium

0.02

Phosphate

0.3

Barium

0.07

Selenium

0.03 
Recent studies of Jackson, et al. [1975] evaluated the compositions of leachate from spent Utah oil shales. Their results, presented in Table X-9, indicate the existence of large concentrations of fluoride, relative to potable water standards, i.e., $4.2 \mathrm{mg} / 1$ versus $1.2 \mathrm{mg} / \mathrm{l}$. It should be noted that in the Utah shale studies acid leaching was not performed for uranium recovery. Trace metals were not reported by this study.

The composition of the specific shale being processed affects the composition of the residual tailings. In view of the great variety of substances present in the Chattanooga Shale under consideration (see Table $\mathrm{X}-10$ ) it is possible for many substances to be present in the spent shale. The solubility and transportability of spent shale constituents depends upon the chemical environment established between the percolating water and the spent shale.

The effects of the chemical.environment upon the mobility of elements in the:supergene environment are illustrated in Table $X-11$. The proposed tailings disposal scheme discussed later would result in an alkaline reducing environment.

\section{WASTEWATER MANAGEMENT}

Discussed below are methods for treating and disposing of the process wastes generated as described above.

\section{Treatment}

The nature of the process wastewaters precludes their disposal into the surface water environment. Similarly, their salinities are great enough to adversely impact the quality of groundwaters in the region. These considerations along with the 1985 zero discharge requirement of the U.S. Environmental Protection. Agency necessitate the utilization of zero discharge disposal techniques. Discharge of process wastewater to 
TABLE X-9. WATER QUALITY OF LEACHATE FROM SPENT UTAH SHALE [a]

\begin{tabular}{lc}
\hline Constituent & Concentration [b] \\
\hline Calcium & 67 \\
Magnesium & 0.3 \\
Sodium & 12 \\
Potassium & 6.5 \\
Boron & 0.11 \\
Carbonate & 47 \\
Sulfate & 53 \\
Chloride & 5.5 \\
Nitrate & 0.2 \\
Fluoride & 4.2 \\
Silica & 25 \\
Total Dissolved Solids & 308 \\
Organic Carbon & 38 \\
pH & 11.2
\end{tabular}

[a] Source: Jackson, et al. [1975]

[b] All units in $\mathrm{mg} / \mathrm{l}$, except $\mathrm{pH}$ 
TABLE $X-10$. ELEMENTAL COMPOSITION OF THE CHATTANOOGA SHALE [a]

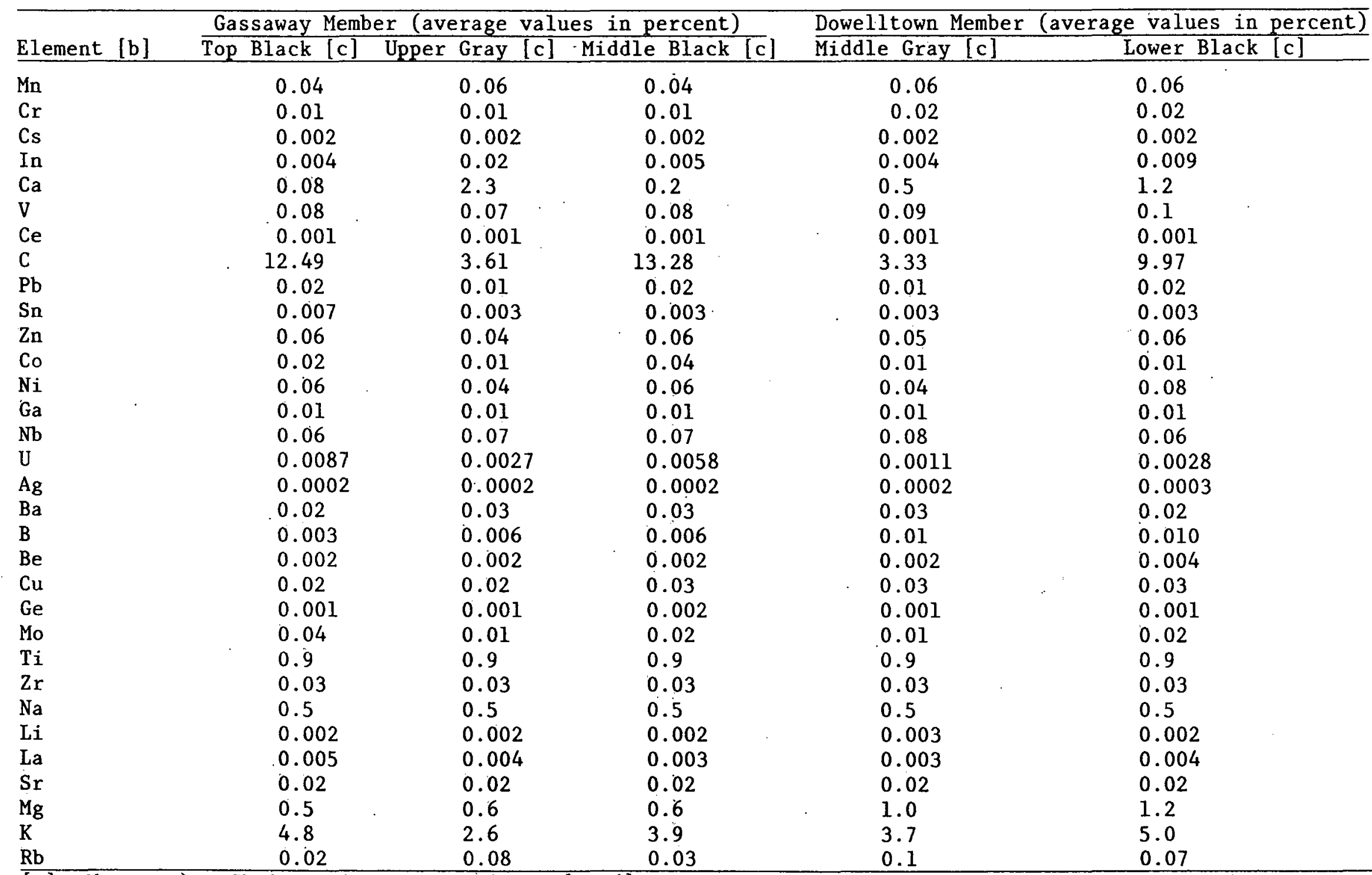

[a] Chattanooga Shale analyses from 0'Neil [1956]. Analyses for units within the Chattanooga Shale are averaged based upon 61 randomly selected samples from two drill cores.

[b] The following elements were nöt detected due to limits of equipment sensitivity: As, Y, Hf, Hg, Sc, $\mathrm{Rh}, \mathrm{Lu}, \mathrm{Se}, \mathrm{Tc}, \mathrm{Cd}, \mathrm{Bi}, \mathrm{Th}, \mathrm{Ti}, \mathrm{Pd}, \mathrm{Os}, \mathrm{Rn}, \mathrm{Tb}, \mathrm{Sb}, \mathrm{Pt}, \mathrm{Ta}, \mathrm{W}$.

[c] Unit names correspond to Upper, Middle, and Lower Gassaway, and Upper and Lower Dowelltown. 


\begin{tabular}{lcccc}
\hline Relative & \multicolumn{4}{c}{ Environmental Conditions } \\
\cline { 2 - 4 } Mobilities & Oxidizing & Acid & Neutral to Alkaline & Reducing \\
\hline Very'high & $\mathrm{Cl}, \mathrm{I}, \mathrm{Br}$ & $\mathrm{Cl}, \mathrm{I}, \mathrm{Br}$ & $\mathrm{Cl}, \mathrm{I}, \mathrm{Br}$ & $\mathrm{Cl}, \mathrm{I}, \mathrm{Br}$ \\
$\mathrm{S}, \mathrm{B}$ & $\mathrm{S}, \mathrm{B}$ & $\mathrm{S}, \mathrm{B}$ & \\
& & & $\mathrm{Mo}, \mathrm{V}, \mathrm{U}, \mathrm{Se}, \mathrm{Re}$ & \\
\hline
\end{tabular}

\begin{tabular}{|c|c|c|c|c|}
\hline \multirow[t]{2}{*}{ High } & $\begin{array}{l}\text { Mo, V, U. Se, Re } \\
\mathrm{Ca}, \mathrm{Na}, \mathrm{Mg}, \mathrm{F}, \mathrm{Sr}, \mathrm{Ra}\end{array}$ & $\begin{array}{l}\text { Mo, V, U, Se, Re } \\
\mathrm{Ca}, \mathrm{Na}, \mathrm{Mg}, \mathrm{F}, \mathrm{Sr}, \mathrm{Ra}\end{array}$ & $\mathrm{Ca}, \mathrm{Na}, \mathrm{Mg}, \mathrm{F}, \mathrm{Sr}, \mathrm{Ra}$ & $\mathrm{Ca}, \mathrm{Na}, \mathrm{Mg}, \mathrm{F}, \mathrm{Sr}, \mathrm{Ra}$ \\
\hline & $\mathrm{Zn}$ & $\begin{array}{c}\mathrm{Zn} \\
\mathrm{Cu}, \mathrm{Co}, \mathrm{Ni}, \mathrm{Hg}, \mathrm{Ag}, \mathrm{Au}\end{array}$ & & \\
\hline
\end{tabular}

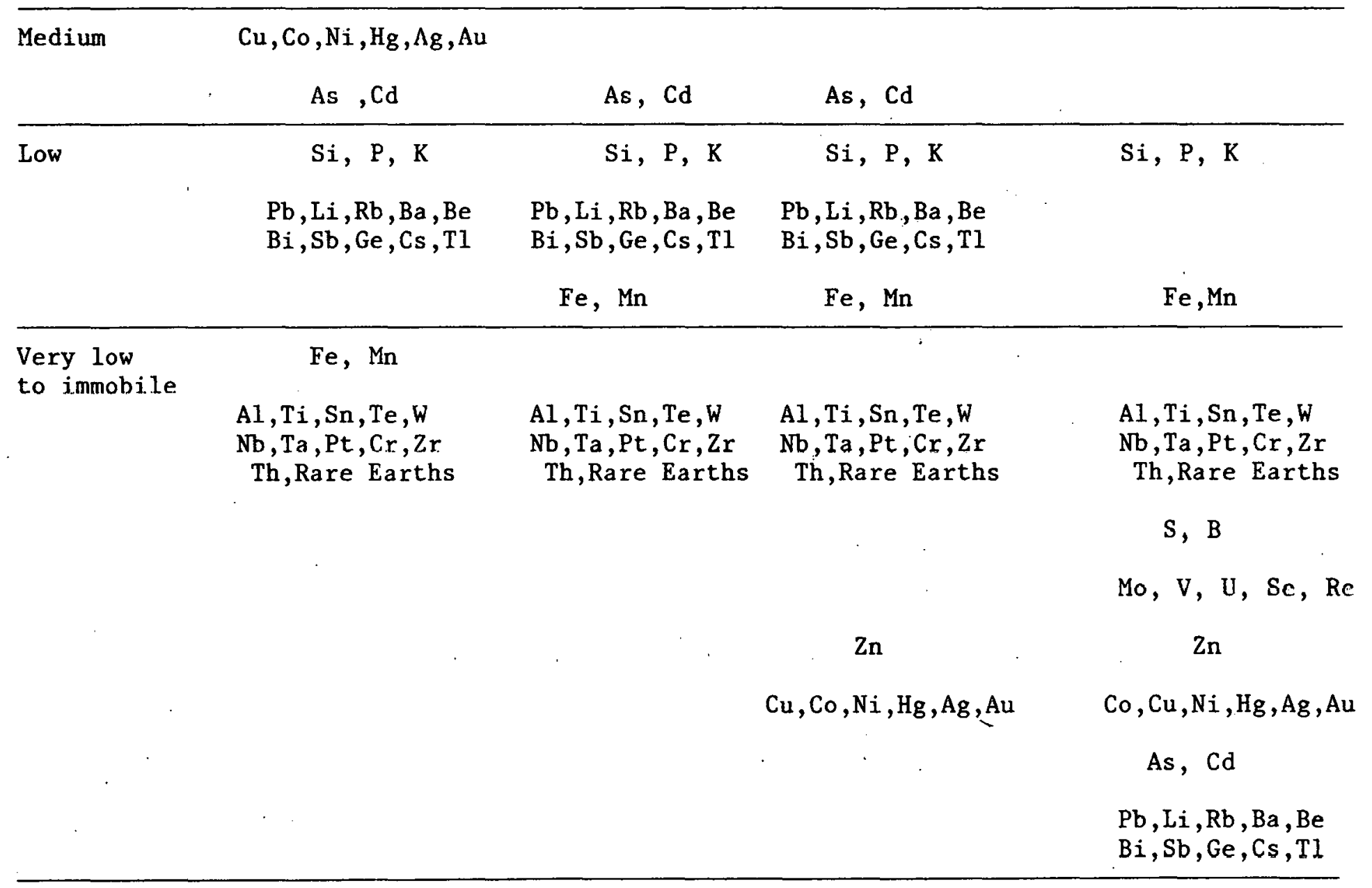

[a] Source: Andrew-Jones [1968] 
- tailings ponds would not meet zero discharge criteria since the regional precipitation exceeds evaporation. One possible zero discharge treatment scheme is illustrated in Figure $\mathrm{X}-7$.

All process wastewaters generated at the site can be treated by the Figure X-7 treatment scheme. The large concentration of organics present and the relatively small volume of the retort water favors its separate treatment or pretreatment. The presence of organics necessitates the use of an oxidation process such as ozonation, permanganate addition, or high temperature oxygenation. Oxidation should convert the majority of organics to carbon dioxide. The residual wastewater will be enriched in inorganics and will require demineralization prior to disposal. An in-depth study is necessary to determine if centralized treatment subsequent to oxidation is advantageous.

The lime softening reduces the calcium concentration and prevents calcium sulfate scaling in the reverse osmosis (RO) unit. The RO brine is further concentrated by vapor compression evaporation as currently practiced by the power industry. The final process is fluidized-bed incineration. The evaporated water and the RO permeate exhibit excellent quality and would be used to supply process water.

\section{Deep Well Injection}

The Knox Formation contains a brackish water aquifer at a depth of approximately $2 \Xi 00$ feet. It is possible that process wastewaters or wastewater brines could be discharged into this saline aquifer without environmental degradation. The technical viability and general acceptability of deep well disposal of industrial process waters in Tennessee require further clarification.

Tailings Disposal

The management of tailings generated by uranium milling operations requires careful planning. Although the concentration of radioactivity 


\section{ZERO DISCHARGE TREATMENT SCHEME FOR ALL PROCESS WASTE STREAMS}

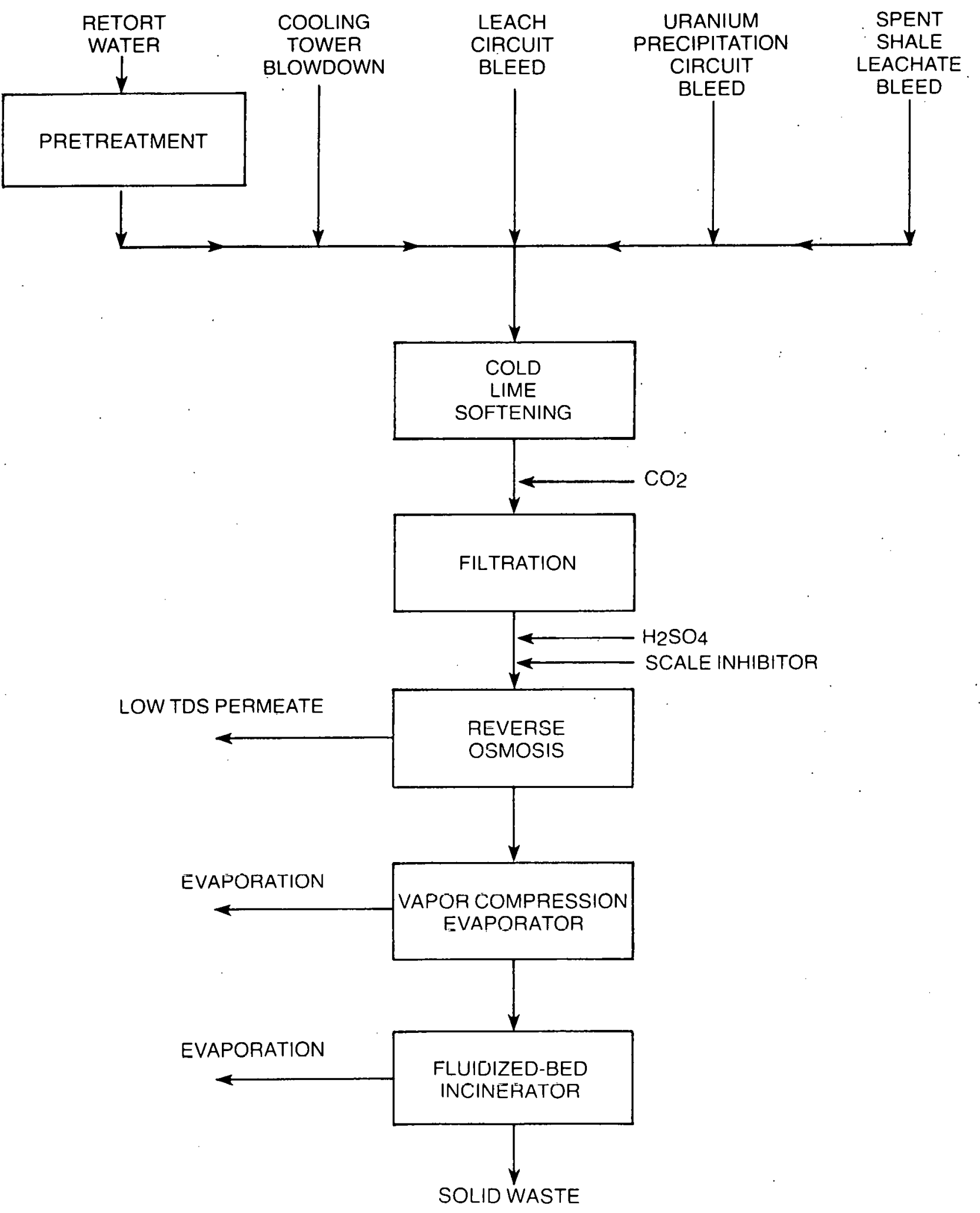

FIGURE X-7 
in the tailings is low, control measures are necessary because of the large quantities involved and because of the long half-life of the parent radionuclides that are present.

Tailings management has been receiving increasing attention from Federal and state agencies and from environmental interest groups. The thrust of this attention is upon requiring well-planned tailings management programs prior to creation of the tailings, with financial provisions to insure execution of the programs. The major concerns of the regulatory agencies are directed to radon release and isolation of the tailings from the human environment. Performance objectives for tailings management have been developed by the staff of the Nuclear Regulatory Commission (NRC) and are presented in Section XIV.

As described earlier, it is proposed that the operation under consideration herein will be conducted such that the mine will enable hydraulic backfilling of tailings: It has been assumed that 70 percent of the tailings produced by the process plant can be placed underground as backfilled material. The remaining 30 percent of tailings will be placed on the surface in tailings disposal areas.

\section{Surface Disposal}

Based upon the performance objectives for tailings management discussed above and outlined in Section XIV it seems clear that the NRC will require a sound mill tailings management program. Available information from the NRC suggests that disposal areas be located so that population exposures are reduced to the maximum extent reasonbly achievable.

The flow of leachate from the tailings ponds can be prevented or minimized, the need depending upon the potential environmental consequences of escaped solutions.

The impoundment area might be a natural basin, modified to be protected from natural forces such as flooding and excessive seepage. This would require facilities to divert natural flows around the site, and to 
provide an impermeable layer on the basin floor and connected to the impervious impoundment structure. Figure X-8 illustrates a typical tailings impoundment during active mining operation.

The use of impermeable liners beneath tailings impoundments is an effective but costly means of preventing subsurface leachate flow. Based upon an installed linear cost of $\$ 1.25$ per square foot and a tailings disposal pond depth of 100 feet, tailings ponds will cost approximately $\$ 0.70$ per cubic yard. This cost is exclusive of any tailings transportation or placement costs and simply represents the capital costs of a lined pond. Obviously, the cost is large and other less costly techniques would be preferable if they produce environmentally acceptable results. Pond linings are never 100 percent effective in preventing seepage and it is therefore necessary to monitor for seepage with a series of wells located in the downstream direction of groundwater flow. Samples from these wells are analyzed on a periodic basis to detect any leakage.

After placement and dewatering, the tailings need to be covered with an impermeable liner and with a soil cover several feet thick. The final reclamation plan would call for shaping, contouring, and planting the impoundment area in such a way as to minimize long-term exosion of the cover material. Figure $X-9$ shows an impoundment after closure.

The rainfall falling directly on the tailings pond will ensure that the tailings always remain saturated. It might be necessary to provide for dewatering of the soil layer overlying the tailings to permit growth of native vegetation. Proper design of surface and subsurface soil drainage systems will enable complete containment of all solutions in contact with the tailings.

Methods of tailings pond seepage control less costly than lining the impoundment may be effective. An alternate technique for eliminating subsurface flow is to locate the pond on a relatively impervious stratum such as the unfractured shale illustrated in Figure $\mathrm{X}-10$. The suitability of this technique depends upon the integrity of the impervious strata 


\section{SCHEMATIC DIAGRAM OF TAILINGS POND \\ DURING ACTIVE OPERATIONS}

SURFACE

WJATER

DIVERSION
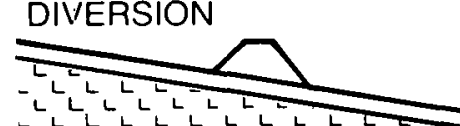

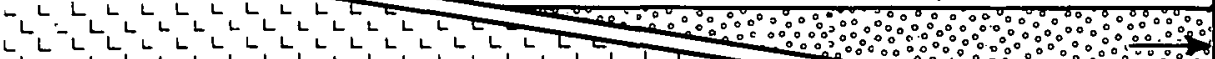

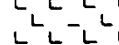

$L^{L} L-L$

每

每

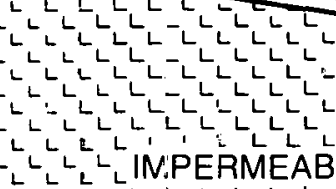

每

年

RECY

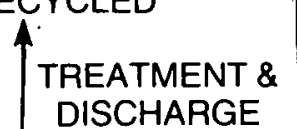

DISCHARGE

FIGURE X-8 


\section{SCHEMATIC DIAGRAM OF TAILINGS POND AFTER CLOSURE}

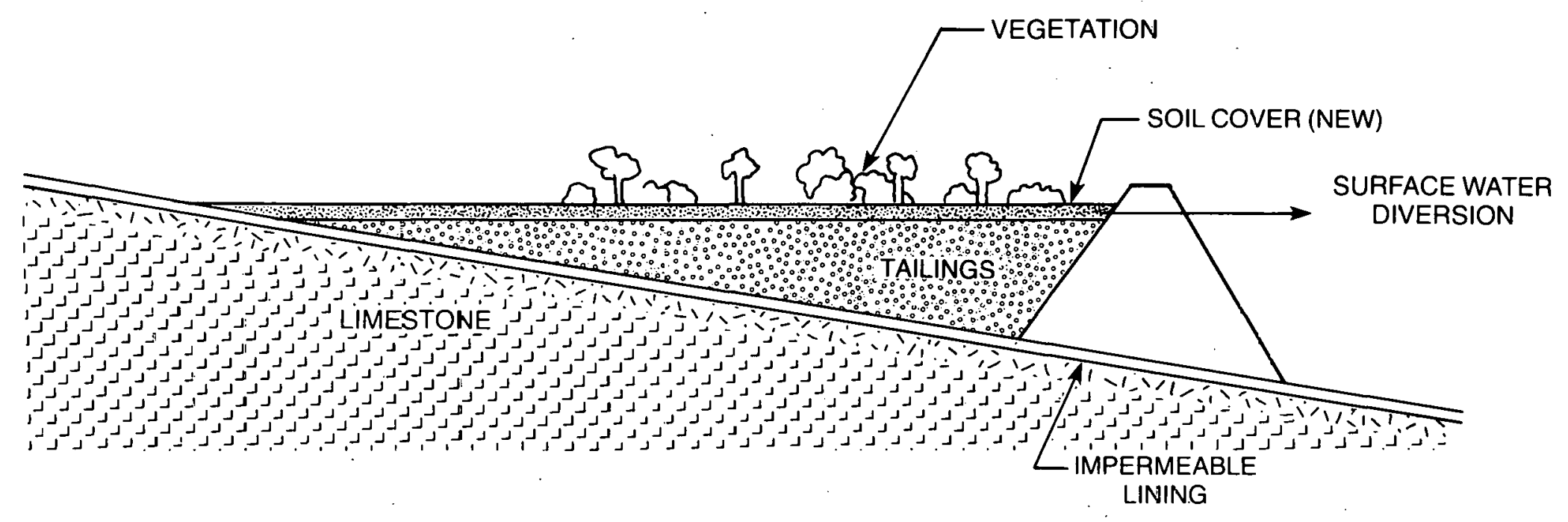

FIGURE X-9 


\section{UTILIZATION OF NATURAL FEATURES TO ISOLATE TAILINGS}

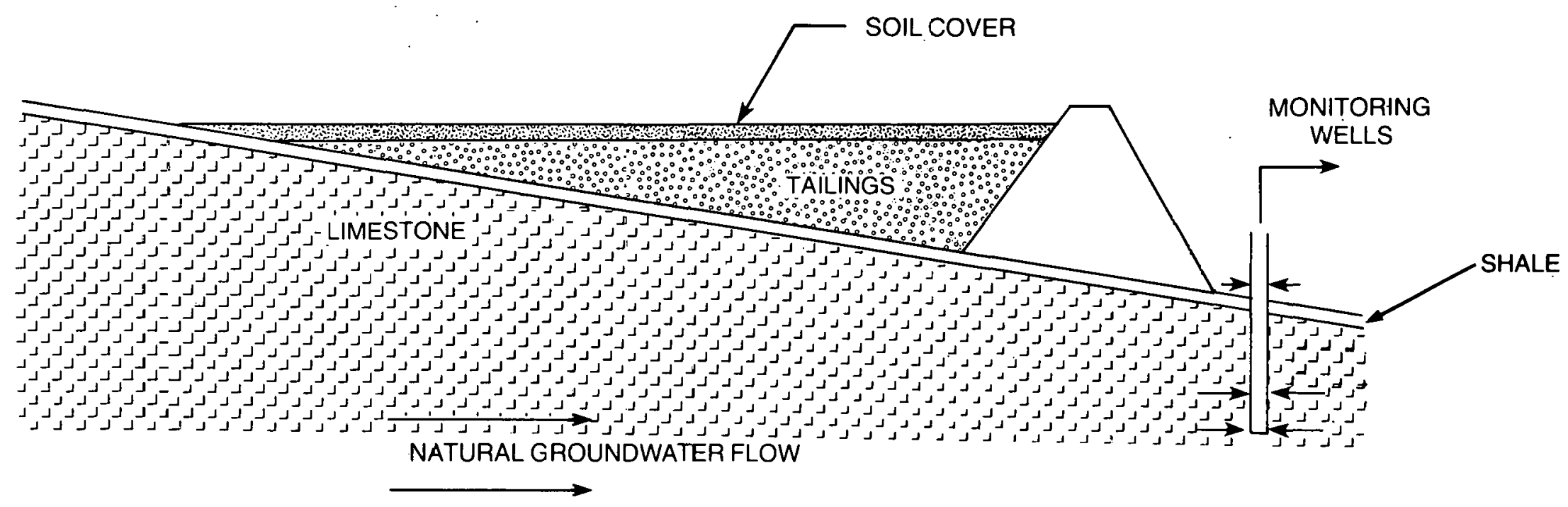

FIGURE $X-10$ 
and the composition of the leachate. It is possible that sufficient treatment of waste tailings prior to disposal, and minimization of surface infiltration could reduce the volume of seepage with this technique to environmentally acceptable levels. The effectiveness of such a procedure would require demonstration.

\section{Subsurface Disposal (Mine Backfilling)}

To allow for hydraulic backfilling of tailings it has been proposed that mining advance in the down-dip direction, and panels have been laid out with 75-foot thick barrier pillars on all sides. A system of roof-hung feeder and distribution lines will be used to hydraulically transport tailings to the mined areas. A system of horizontal underdrains and vertical perforated drains will be installed to remove excess water from the stowed tailings. Water from the panel drainage system will be pumped to the surface and returned to the process plant for recycling. In order to reduce the formation of sulfuric acid, it will be necessary to maintain the backfilled tailings in a saturated condition thereby preventing an aerobic environment.

Some seepage can be expected from the backfilled tailings into both the overlying and underlying limestone formations. As shown in Figure $\mathrm{X}-11$, in areas where the overlying aquifer has been dewatered by the mining operation, seepage from the tailings will freely enter the fractured limestone as the result of the piezometric head developed by the downdipping panels. The overlying aquifer will be susceptible to contamination even with the water table in a position above the mine roof. Seepage into the underlying limestone will be caused by the piezometric head within the saturated tailings. Exposed fractured limestone on the floor of the mine can be expected to be more permeable than shale left in place. The contamination of both the upper and lower aquifers could degrade both springs and wells. It is also possible that spring flow will be increased, particularly from the lower aquifer. Figure X-12 is a schematic of the geologic formation cross-section, which illustrates the potential pathways for seepage water to enter the surface environment. 


\section{SEEPAGE FROM HYDRAULICALLY BACKFILLED MINES}

GROUND SURFACE

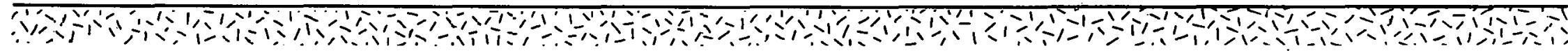

\section{WATER TABLE ELEVATION}

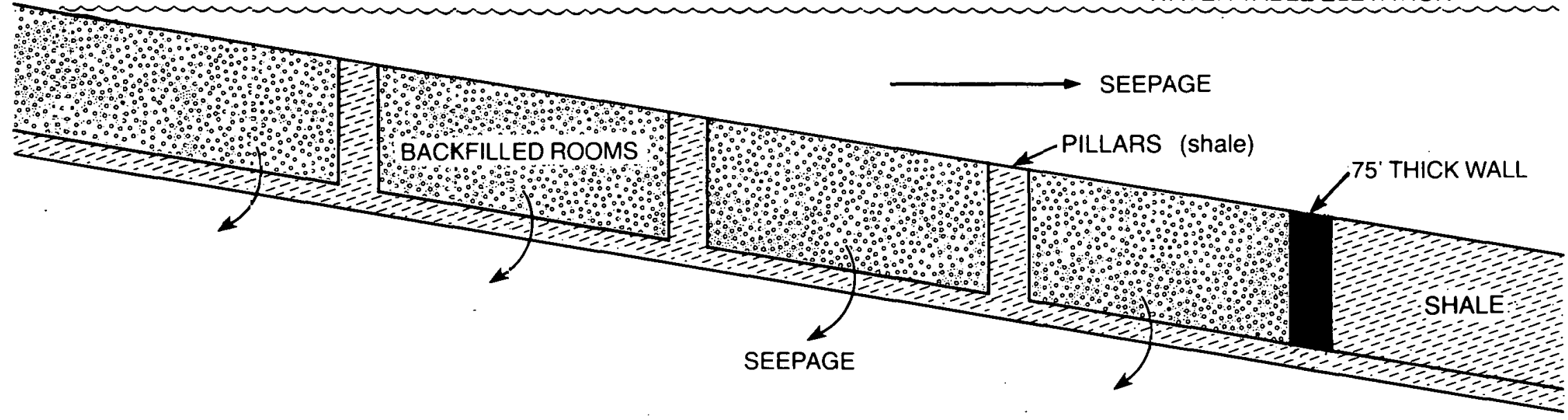

FIGURE $X-I I$ 


\section{GEOLOGIC CROSS SECTION ILLUSTRATING POTENTIAL PATH FOR SURFACE WATER CONTAMINATION}

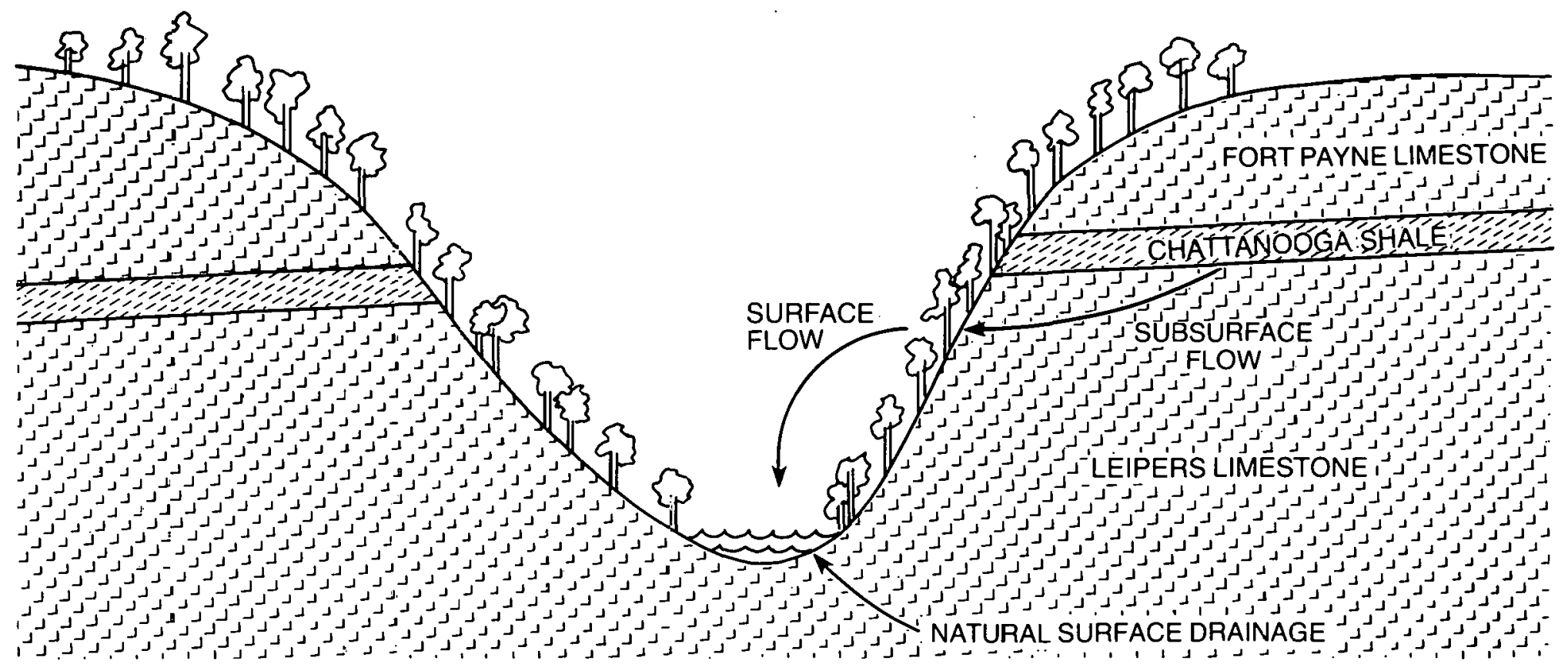

FIGURE $X-12$ 
After completion of the backfilling operation, maintenance of the tailings in a saturated condition may not be possible if shale removal permits seepage to be lost to a permeable formation at a rate faster than replenishment water is available. Dewatering the tailings could lead to the formation of sulphuric acid. Seepage through the floor will be reduced by leaving a layer of unmined Dowelltown shale throughout the mine. Seepage upward through the roof at the lower ends of panels would be more difficult to control if it was found impossible to maintain the water table at a level above the tailings.

It is highly improbable that complete integrity of synthetic or natural strata will be maintained for any period of time and it is reasonable to assume that leachate will enter the limestone formation directly below the backfilled mines. Several techniques have been proposed for adding chemicals to reduce the permeabilities of backfilled tailings. Such techniques are acceptable if adequate permeability reductions occur and if the results are long-term.

\section{EUTROPHICATION}

Eutrophication of rivers and lakes is a potential problem if limiting nutrients generated in the mining operations enter surface waters directly or via subsurface pathways. Surface waters are typically deficient in nitrogen, phosphorus, or both. The zero discharge requirement prohibits the direct input of nutrients to surface waters. The possibility does remain, however, that tailings wastewater containing nutrients will flow from the hackfilled mines and enter the surface water environment. The presence of large amounts of limestone in the study area precludes the subsurface transport of phosphate due to its precipitation and sorption. Nitrogen has a greater potential for being transported through the subsurface environment and being released into surface waters where eutrophication may result. Future in-depth environmental studies should identify the limiting nutrients in neighboring surface waters to determine the potential for eutrophication. 


\section{SECTION XI \\ BIOLOGICAL RESOURCES}

As impacts to the biological character of a given area are by their nature quite site-specific,' the examination of impacts presented in this section is restricted almost exclusively to the local level. It is informative nonetheless to consider briefly the biology of the region in question, such that certain parallels to local-level impacts may be drawn.

\section{DESCRIPTION OF EXISTING CONDITIONS}

Due to its predominantly rural undeveloped nature, much of the area under examination retains to a large degree its native biologic character. Principal emphasis in this discussion is devoted to the natural biotic attributes of the region and DeKalb County, with less consideration devoted to artificially-induced biotic communities.

\section{REGIONAL CHARACTERIZATION}

Following is a brief overview description of the principal vegetation communities and wildlife characterizing the regional study area.

\section{Vegetation}

The authoritative work of Kuchler [1964] distinguishes five major natural vegetation communities within the boundaries of the regional study area, as depicted in Figure XI-1. These communities constitute three broadleaf forests types, one broadleaf-needleleaf forest type, and two grasslandforest combination types. Although Figure XI-1 conveys the impression of uniform stands of vegetation throughout a given community, such is not the case. Due to localized variations in habitat conditions, certain plant species dominant'in one area may bc entirely abcent from another. 


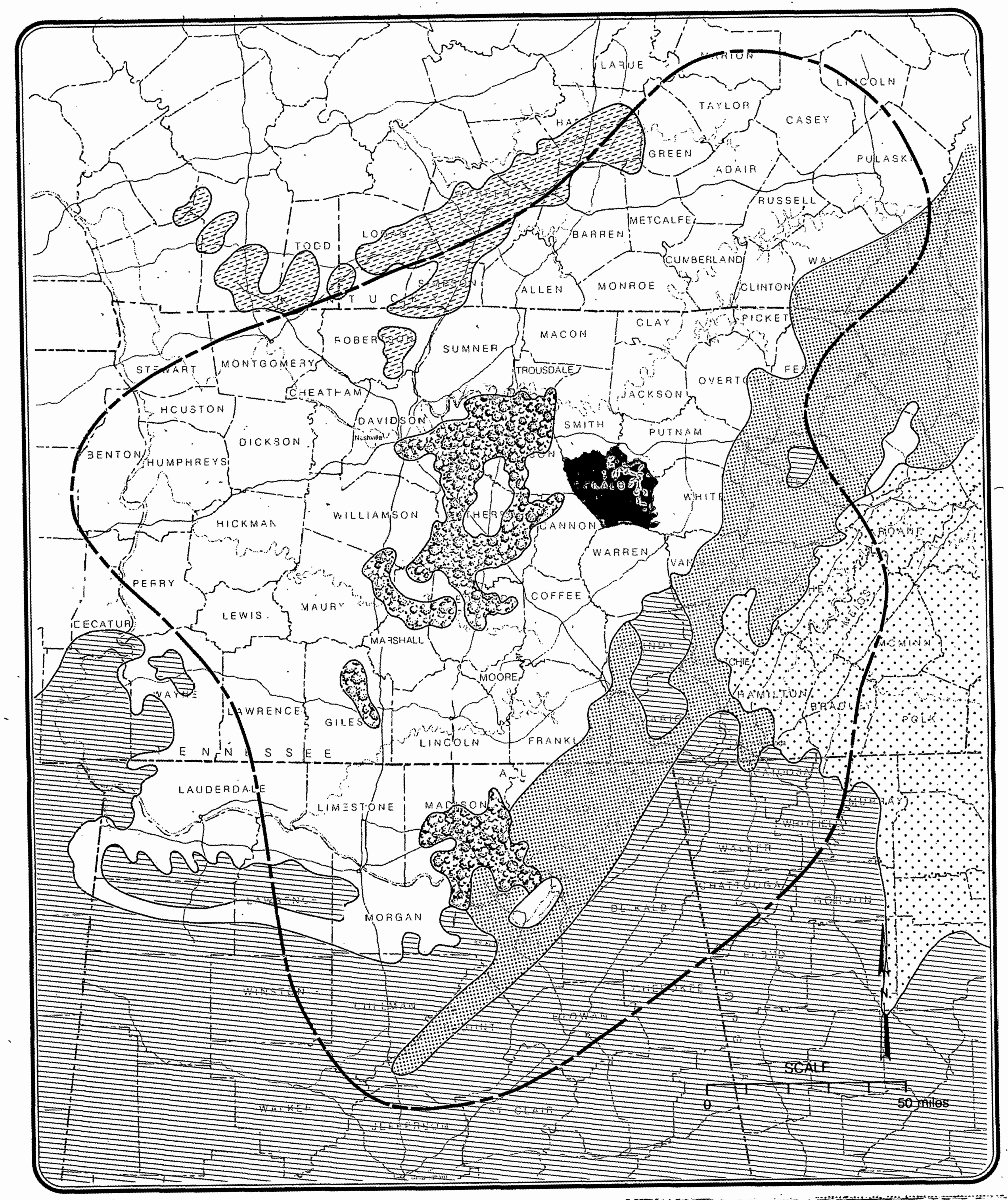

POTENTIAL NATURAL VEGETATION WITHIN THE REGIONAL STUDY AREA (adapted from Küchler [1964])
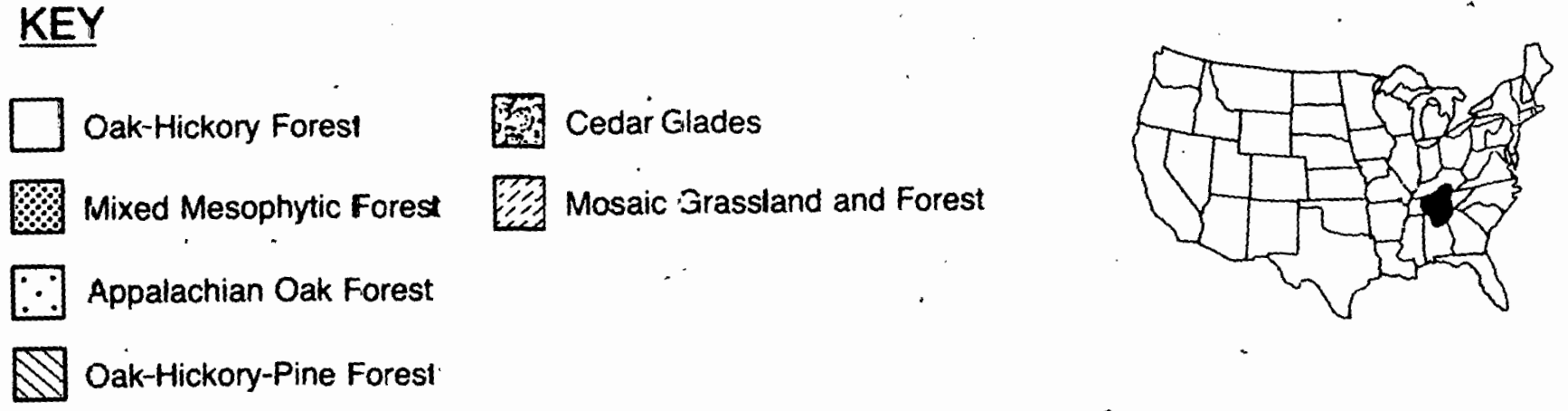
Dominant and major species characterizing each community are listed in Appendix E, Tables E-1-a through E-1-f. A brief description of each of the five major community types follows.

Oak-hickory forest is the predominant vegetational community within the regional study area. This is a medium-tall to tall (40-100 feet) broadleaf deciduous forest dominated by bitternut hickory (Carya cordiformis), shagbark hickory (Carya ovata), white oak (Quercus alba), red oak (Quercus rubra), and black oak (Quercus velutina). A number of other hickories and oaks, as well as white ash (Fraxinus americana), black walnut (Juglans nigra), black cherry (Prunus serotina), and American basswood (Tilia americana) may occur in varying concentrations throughout the community.

Two other tall (70-140 feet) broadleaf deciduous forest types occur in the eastern portion of the study area. The mixed mesophytic forest found on the Cumberland Plateau and the Eastern Highland Rim is dominated by sugar maple (Acer saccharum), yellow buckeye (Aesculus octandra), beech (Fagus grandifolia), tuliptree, (Liriodendron tulipifera), white oak (Quercus alba), red oak (Quercus rubra), and basswood (Tilia heterophylla). A large variety of other trees occurs in association with the dominant species. The number of dominant species in a given area may vary from only two to as many as twenty species.

The second broadleaf deciduous forest type, Applachian oak forest, occurs in the Appalachian Mountains. This forest is dominated by white oak (Quercus alba) and red oak (Quercus rubra). Several of the trees enumerated above as mixed mesophytic components also characterize the Appalachian oak forest. Prior to 1935 the American chestnut (Castanea dentata) would have been a co-dominant in the Applachian oak forest. However, the species has been virtually extirpated by chestnut blight, an introduced fungus disease affecting the bark.

Oak-hickory-pine forest dominates the southern portion of the study area. This medium to tall (40-100 feet) forest of broadleaf deciduous and needleleaf evergreen trees is dominated by various hickories (Carya 
spp.), shortleaf pine (Pinus echinata), loblolly pine (Pinus taeda), white oak (Quercus alba), post oak (Quercus stellata), and a variety of other species.

Cedar glades are located in the Nashville Basin and in a small part of the southern portion of the study area. This community is a low to medium-tall (7-25 inches) open grassland with scattered needleleaf shrubs and groves of low to medium-tall (30-50 feet) broadleaf deciduous trees. Dominants include hackberry (Celtis laevigata), red cedar (Juniperus virginiana), winged elm (U1mus alata), and poverty grass (Sporobolus vaginiflorus). Other species of grasses, forbs, shrubs, and trees may occur as local dominants within the community.

Along the northern border of the study area is located a mosaic of bluestem prairie and oak-hickory forest communities. The bluestem prairie community is dominated by tall (2-7 feet) grasses and many forbs, through which are scattered individual islands of unadulterated oak-hickory forest. The oak-hickory forest does not blend or merge with the bluestem prairie; rather, each community retains its integrity.

\section{Wildlife}

A large variety of wildlife species occurs throughout the study area. Some of the more common species include: Virginia opossum (Didelphis marsupialis), short-tailed and least.shrews (Blarina brevicauda and Cryptotis parva), eastern mole (Scalopus aquaticus), eastern chipmunk (Tamias striatus), eastern cottontail (Sylvilagus floridanus), woodchuck (Marmota monax), gray squirrel (Sciurus carolinensis), fox squirrel (Sciurus niger), southern flying squirrel (Glaucomys volans), eastern harvest mouse (Reithrodontomys humulis), white-footed mouse (Peromyscus leucopus), eastern woodrat (Neotoma floridana), pine vole (Microtus pinetorum), muskrat (Ondatra zibethica), beaver (Castor canadensis), and several bat species. Lafger animals present include: red fox (Vulpes fulva), gray fox (Urocyon .cinereoargenteus), raccoon (Procyon lotor), mink (Mustela vison), skunk (Mephitis mephitis), bobcat (Lynx rufus), and white-tailed deer (Odocoileus virginianus). 
A number of birds are winter residents, migrate through the area, and/or are permanent residents. Among the common species groups are: hawks, woodpeckers, flycatchers, swallows, wrens, thrashers, vireos, tanagers, sparrows, and warblers. Ducks, herons, bitterns, and shore birds are associated with the water bodies occurring throughout the region.

\section{LOCAL CHARACTERIZATION}

Since the prototype project location anticipated herein is in the vicinity of Center Hill Lake, emphasis in the following descriptions will be addressed to this area, particularly in the case of wildlife.

\section{Vegetation}

As discussed in Section VIII, DeKalb County naturally segregates into three physiographic regions: 1) Undissected Eastern Highland Rim; 2) Dissected Eastern Highland Rim; 3) Outer Central Basin. Because of broad topographic, edaphic, and historical differences characterizing these three regions, the gross vegetational pattern of the area corresponds thereto. It is obvious from early accounts that the edaphic dissimilarities between the regions originally were expressed by dramatic vegetative differences--from oak-chestnut-hickory flatwoods with trees of medium stature to massive mesophytic hardwoods with extensive canebrakes.

In summary, the present vegetational patterns of the tableland of the Undissected Eastern Highland Rim, of the entire Dissected Eastern Highland Rim, and the Central Basin are mostly the product of civilization and scarcely reflect physiographic control. This is in sharp contrast to the steeper portions of the Caney Fork River gorges which maintain much of their original vegetational character.

Subtle variations in topographic and edaphic characteristics within the physiographic regions suggest their differentiation into subdivisions. 
The most convenient and meaningful set of subdivisions is as follows:

I. Undissected Eastern Highland Rim [UEHR]

(a-1) Lower and Middle Slopes of the Caney Fork River Gorge and Tributary Gorges (mixed mesophytic forest)

(a-2) Drier Upper Slopes of the Caney Fork River Gorge and Tributary Gorges (oak-hickory-hardwoods)

(a-3) Drastically Disturbed Sites of the Caney Fork River Gorge and Tributary Gorges (tuliptree-sweet gum-white ash)

(b) High Valleys (mixed hardwoods)

(c) Tablelands (fields, pastures, pine stands, oak-tuliptree woods )

(d) Tableland Swamps (willow oak-sweet gum-red maple)

II. Dissected Eastern Highland Rim [DEHR]

(a) Broad Valleys (fields, pastures, tuliptree woods)

(b) Narrow Valleys (pastures, mixed hardwoods-beech)

(c) Rocky Hillsides (red cedar-hardwoods)

(d) Hillsides with Deep Soil (fields, pastures, weedy succession)

(e) Hill Crests (chestnut oak-oaks-hickories-hardwoods)

(f) Alluvial Plains (mixed hydrophytic hardwoods)

III. Outer Central Basin [OCB] (Mississippi hackberry-red cedar-white ash-broomsage)

Each of these specific areas and subareas is described below and is broadly delineated in Figure XI-2. Principal taxa occurring in these vegetational regions are listed in Appendix E, Tables E-2-a through E-2-j. Additionally, Appendix E, Table E-2-k presents a list by taxonomic group of representative vascular flora of Dekalb County, emphasizing the Center Hill reservoir vicinity. 


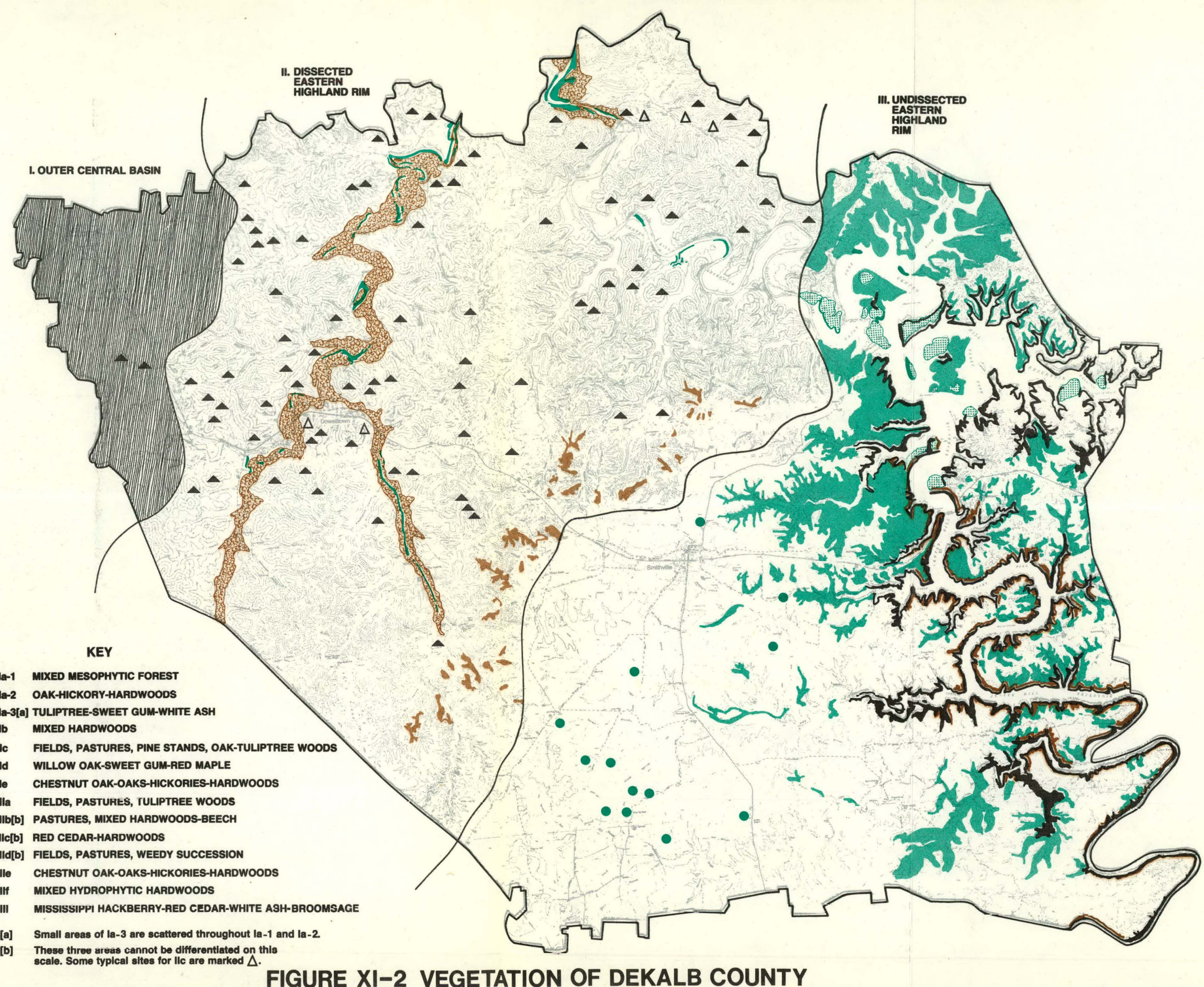

FIGURE XI-2 VEGETATION OF DEKALB COUNTY 
Mixed Mesophytic Forest of the UEHR (I-a-1)

The gorges of the lower and middle slopes of the Caney Fork River and its tributaries were originally covered with mixed mesophytic forest as described by Braun [1950]. Depending upon isolation and degree of cutting and subsequent disturbance, there are still large tracts which can be classified as mixed mesophytic. They are dominated by sugar maple (Acer saccharum), basswood (Tilia heterophylla), tuliptree (Liriodendron tulipifera), beech (Fagus grandifolia), and bitternut (Carya cordiformis).

Oak-Hickory-Hardwoods Association of the UEHR (I-a-2)

Drier sites toward the tops of the gorges of the Caney Fork River and its tributaries are dominated by a mixture of oaks, hickories, and hardwoods. Oak and hickory species present include white oak (Quercus alba), black oak (Quercus velutina), scarlet oak (Quercus coccinea), chestnut oak (Quercus prinus), southern red oak (Quercus falcata), shagbark hickory (Carya ovalis), and pignut hickory (Carya glabra). Hardwoods present include black gum (Nyssa sylvatica) and tuliptree (Liriodendron tulipifera). The most characteristic species of these upper slopes is mountain laurel (Kalimia latifolia).

Tuliptree-Sweet Gum-White Ash Association of the UEHR (I-a-3)

More drastically disturbed sites of the Caney Fork River and tributary gorges (especially if burned or cultivated rather than merely logged) are dominated by sweet gum (Liquidambar styraciflua), tuliptree (Liriodendron tulipifera), white ash (Fraxinus americana), box elder (Acer negundo), red maple (Acer rubrum), dogwood (Cornus florida), and hackberry (Celtis occidentalis). If cultivated, these areas pass through a protracted broomsage-cedar stage. 
Mixed Hardwood Forests of the UEHR (I-b)

Although, as suggested by the physiographic terminology, most of the surface of the Undissected Highland Rim is tableland, there are numerous narrow valleys throughout, the steep sides of which have precluded continuous cultivation or pasturage. These valleys are usually covered with attenuated hardwood forest consisting of the following most common taxa: tuliptree (Liriodendron tulipifera), sweet gum (Liquidambar styraciflua), post oak (Quercus stellata), southern red oak (Quercus falcata), scarlet oak (Quercus coccinea), mockernut (Carya tomentosa), and red maple (Acer rubrum). Richer sites support many beeches (Fagus grandifolia) and sugar maples (Acer saccharum) as transgressives, with a few scattered hardwoods typical of the mixed mesophytic forest community.

Fields, Pastures, Pine Stands, Oak-Tuliptree Woods of the UEHR (I-C)

Most of this category occurs on flat and accessible tableland which is or has been cleared and put under grazing or cultivation. It is, therefore, represented by stagès ranging from tilled fields through fallow fields, old fields in various stages of succession, planted pine plots (Pinus teada) to small woodlots vaguely resembling the oak-hickory forest once dominant here. The general pattern of succession is cultivated field, weed-dominated field (aster-golden aster-ragweed-goldenrod), broomsage (Andropogon virginicus), blackberry-persimmon-sassafras (or Virginia pine, or red cedar), and finally to oak-hickory.

Willow Oak-Sweet Gum-Red Maple Swamps of the UEHR (I-d)

This swamp community occurs in low, poorly-drained areas of the general tableland and is sufficiently different vegetationally from other tableland communities to deserve special mention. The community is a welldeveloped entity throughout the Eastern Highland Rim and has attracted attention because it harbors Coastal plain taxa such as willow oak (Quercus phellos), Virginia chain-fern (Woodwardia virginica), and water-willow (Decodon verticillatus). 
Chestnut Oak-Oaks-Hickories-Hardwoods Association of the UEHR (I-e)

The crest of extensions (spurs) which are fully continuous within the Undissected Highland Rim but extensively interrupt valleys of the Dissected Rim are vegetationally distinct from other areas of the Undissected Highland Rim. These spurs are, however, quite similar vegetationally to the hill crests of the Dissected Rim (Region II-e); therefore, the two regions are served by the same floristic table in Appendix E. The most distinctive feature of these spurs is the dominance of chestnut oak (Quercus prinus L., not to be confused with Quercus prinus Sarg.). The principal difference, vegetationally, between the spurs of the Undissected Rim and the hill crests of the Dissected Rim is the virtual absence of shortleaf pine (Pinus echinata) in the latter.

Valley Fields, Pastures, Tuliptree Woods of the DEHR (II-a)

These community types are present in broad valleys of the Dissected Rim which have been intensively farmed since the early 1800's. All are now occupied by houses, fields, lots, pastures, and woodlots. Some worn-out fields and pastures have been allowed to grow back into weedy woods. The cultivars, grasses, and weeds characterizing these valleys have been omitted from consideration in Appendix $\mathrm{E}$.

Mixed Hardwoods-Beech Association of the DEHR (II-b)

This association occurs in narrow valleys of the Dissected Rim which differ from the broad valleys only in that they are somewhat less disturbed and embrace a greater proportion of wooded areas. In these wooded areas there is a preponderance of tuliptree (Liriodendron tulipifera) with an admixture of calciphilic hardwoods: sugar maple (Acer saccharum), beech (Fagus grandifolia), chinquapin oak (Quercus muhlenbergii), white oak (Quercus alba), black walnut (Juglans nigra), Shumard oak (Quercus shumardii), Ohio buckeye (Aesculus glabra), shagbark hickory. (Carya ovata), kingnut (Carya laciniosa), box elder (Acer negundo), red mulberry 
(Morus rubra), sweet gum (Liquidambar styraciflua), and white ash (Fraxinus americana). Dogwood (Cornus florida), redbud (Cercis canadensis), red haw (Crataegus spp.), black haw (Viburnum rufidulum), and Carolina buckthorn (Rhamnus caroliniana) are common in the sub-canopy.

\section{Red Cedar-Hardwoods Association of the DEHR (II-c)}

One of the characteristic vegetational features of the Dissected Rim in 'DeKalb County (and contiguous counties to a lesser degree) is the uniform invasion of old pastures by red cedars (Juniperus virginiana). It is clear that on thousands of.acres of land, the attempt to establish pastures after clearing the hardwoods has been a failure. The erosion and exposure resulting from the attempt has given rise to a situation in which no other plants can compete with red cedars. Thus, all along the line of hills and valleys comprising the Dissected Rim, rocky lower and middle slopes are covered by red cedars or are in some stage of being covered thereby. In many of these stands, some old diseased remnants of the hardwood forest remain as isolated individuals. Chief among them are chinquapin oak (Quercus muhlenbergii), white oak (Quercus americana), and an occasional sugar maple (Acer saccharum). Rarely are these or other typical non-cedar taxa present in sufficient numbers to constitute a.significant threat.

Hillside Fields, Pastures, Weedy Succession of the DEHR (II-d)

Steep hillsides with almost continuous deep surface soil are:normally present in pastureland. Many show signs of past cultivation, and some have been ruined to the point of becoming classified as vegetational region II-c, upon excessive surface exposure of rocks. These hillside pastures are remarkably fragile, tending with neglect or overgrazing to be replaced by red cedars or by a very low-grade stand of mixed hardwoods, including osage orange (Maclura pomifera), honey locust (Gleditsia triacanthos), glade privet (Fórestiera ligustrina), buckbush (Symphoricarpus orbiculatus), thistles (Cirsium spp.), ironweed (Vernonia spp.), broomsage (Andropogon virginicus), and bitterweed (Helenium 
amarum). Good pastures in this region are mostly in fescue (Festuca spp.), with an admixture of clovers (Trifolium spp.) and lespedezas (Lespedeza spp.).

Chestnut Oak-Oaks-Hickories-Hardwoods

Association of the DEHR (II-e)

The outlying hills in this area usually have not been cultivated or extensively developed as pastures above the level of the Chattanooga Shale (many not up to that level). Typically, therefore, the hills have fairly extensive "caps" of rocky, oak-hickory woods with an admixture of xerophytic hardwoods. These hilltop forests are very similar in composition to the Rim Spur forests of Section II-e, except that they usually lack shortleaf pine (Pinus echinata).

\section{Mixed Hydrophytic Hardwoods Association of the DEHR (II-f)}

As the Caney Fork River and its tributaries widen upon approaching and entering the Dissected Rim, limited alluvial plains occur. Above the dam the original flood plains, of course, are covered, but below the dam and along some tributaries are small plains, the vegetation of which is fairly characterietic. However, the prominent taxa of the Highland Rim alluvial plains show no essential distinctions from those of the Central Basin discussed next.

Mississippi Hackberry-Red Cedar-White Ash-Broomsage Association of the OCB (III)

The separation between the Dissected Eastern Highland Rim and the Outer Central Basin in DeKalb County is not topographically obvious. The foothills gradually lower until just west of Liberty, they are no longer predominant and may be cultivated or pastured to the tops. This, along with cedars at the top of low rounded hills, signals the beginning of the Outer Central Basin. Vegetationally the sure sign of the Central Basin at present is the preponderance of Mississippi hackberry (Celtis leavigata) in the thickets and fencerows. Principal associates are red cedar (Juniperus virginiana) and white ash (Fraxinus americana). Osage 
orange (Maclura pomifera) is locally abundant. Originally the border of the Basin would have been indicated by the presence of large numbers of red cedar. This is no longer true because red cedar has extensively invaded the rocky hillsides of the Dissected Highland Rim and many old fields of the Undissected Rim as well. In DeKalb County there is no concentration of glade endemics such as are so characteristic of the Inner Basin around Murfreesboro.

\section{Wildlife}

Historically the DeKalb County area, particularly along the Caney Fork River (Center Hill Lake), was extensively populated with a great diversity of animal species. In addition to many small game mammals, bison, elk, turkey, bear, white-tailed deer, and mountain lion were hunted in the area. As the white civilization increased and settled the region, the forested land supporting the indigenous fauna was reduced considerably, and many major terrestrial wildlife species were extirpated.

Both bottom land and hill farming had been practiced since the $1850^{\prime} \mathrm{s}$ along Caney Fork River before the Center Hill Dam closure in 1948. Formation of Center Hill Lake eliminated the bottomland habitat with a concomitant decrease in remaining wildlife.

Terrestrial vertebrates known to presently inhabit the area indicate that it is essentially a faunal transition zone, receiving species contributions $f$ : om northern western, eastern, and southern biota (see Appendix E, Table E-3 for a list of representative wildlife of the DeKalb County area). No complete listing of vertebrates known to inhabit the DeKalb County area has been published. Those species of mammals, birds, reptiles, and amphibians presented in Appendix $E$ have been compiled from private records, published reports, and study team observations. Only those species known or reasonably expected to occur in the area included in the list.

Ecological studies concerned with the Center Hill Reservoir fishery have been conducted by the U.S. Army Corps of Engineers, Tennessee Wildlife 
Resources Agency, Tennessee Technological University, and Tennessee Technological Cooperative Fishery Unit. Appendix E. includes a composite list of the fish species that have been found in the reservoir, at the confluence of tributaries flowing into the lake and the Caney Fork River below the dam. The community is dominated by 17 species of rough fish (23.6\%). Game fish comprise 24.4\% (19 species) and forage fish total $50.0 \%$ (36 species). The 72 species collected throughout the system have been taken by a variety of techniques including electrofishing, gill netting, seining, and cove rotenone samples.

In cove rotenone collections, 28 species have been taken. Catches have been dominated by game fish in both total number $(76.9 \%)$ and total weight $(39.0 \%)$. Bluegill, Green and Longear Sunfish dominate the game fish, reaching 304 individuals per acre and a combined total weight of 11,505 grams per acre. Gizzard shad are the most abundant forage fish by weight ( $95.9 \%$ ) and the minnows (Cyprinidae) are the least abundant by total numbers $(59.2 \%)$. Carp have the greatest rough fish weight of $8,539 \mathrm{gm}$ per acre $(78.8 \%$ ) while drum are the most abundant at $47.1 \%$ of the total number ( 5 per acre). Surveys have disclosed a combined total of 1,270 individual per acre and 35,977 grams per acre of fish.

The most abundant fishes in an aquatic system are not necessarily the most important to man. An important species can be defined as one which is taken in the sport or commercial fishery or directly affects it. In this reservoir, the most important species appear to be black basses (smallmouth, largemouth, spotted), crappie (white, black), walleye, white bass, threadfin shad, gizzard shad, carp, and catfish. The black basses, crappie, and walleye are the most abundant sought-after game fishes in the reservoir. Gizzard and Threadfin Shad are the major forage fishes for these species. The Carp and Catfish are both important components of the commercial fishery in Center Hill Lake.

Ongoing fisheries research at Center Hill Lake is being carried out jointly by the U.S. Army Corps of Engineers, Tennessee Wildlife Resource Agency, Tennessee Technological University, and the Tennessee Cooperative Fisheries Unit. Studics arc bcing directed primarily at generating 
information important to developing a combination of interacting population dynamics models needed in facilitating fish management schemes. To meet this objective it is necessary to determine qualitatively and subsequently quantify those factors which regulate the productivity of game fish populations in the reservoir. The ultimate goal of the research is the development of a computer model which can be used as a tool for simultaneously managing several fish populations in Center Hill. It is envisioned that this model could be adopted to other reservoirs. The site specific data being gathered for constructing a population dynamics model on the fish inhabiting Center Hill Reservoir include the following:

1. Species composition

2. Age-growth relationships for major species

3. Length-weight relationships for major species

4. Fecundity relationships for major species

5. Food habits and requirements for each species

6. Spawning habits for major species

7. Factors. influencing the distribution of fish larvae in time and space

8. Requirements for larval growth and development for major species

9. Dynamics of early life stage survival for major species

10. Exploitation rates for major game fishes

11. Factors which influence the vulnerability of various fishes to exploitation

12. Population abundance estimates for major species

13. Water quality and hydrology of the reservoir

14. Zooplankton and phytoplankton production

No qualitative or quantitative information is available on the benthos of the lake system. A qualitative list of representative organisms has been compiled and is presented in U.S. Army Corps of Engineers [1977]. Extensive benthos assessments have been carried out on a tributary, Falling Water River, and the tailwater stream. One ongoing study on the benthos of the lake is still in its first stages of sampling at Tennessee Technological University and preliminary results should be forthcoming in the near future. 
SECTION XII

AIR RESOURCES

Presented in this section is a projection of the impacts to air quality anticipated from implementation of the project under consideration. To provide a basis for this projection existing regional and local air quality is first characterized. Discussed also are present air quality stadards, air quality trends, and air pollution effects.

\section{DESCRIPTION OF EXISTING CONDITIONS}

Mandated goals, standards, review, and enforcement powers applying to. air quality, as currently structured at the Federal level, are derived from the Clean Air Act Amendments of 1970 (Public Law 91-604). This law vested the U.S. Environmental Protection Agency (EPA) with specific charters to improve the quality of life and general welfare related to air pollution. The EPA has been charged with developing a set of national ambient air quality standards (NAAQS) for pollutants known to have an adverse impact on health and the general welfare. In order to provide a frame of reference within which to consider existing air quality within the study area, a brief discussion of current pertinent air quality standards is warranted.

\section{AMBIENT AIR QUALITY ETANDARDE (AAQE)}

Pursuant to the Clean Air Act Amendments of 1970, the EPA promulgated two sets of AAQS for six air pollutant species, hereinafter designated criteria pollutants. The states have the authority to instigate standards for additional pollutants or to develop AAQS more stringent than the Federal standards. The two types of Federal standards distinguish between a primary standard related purely to health effects, and a 
secondary standard that takes into account potential air pollution effects upon the public welfare. The two sets of standards, as set forth in Part 50 of Title 40 of the Code of Federal Regulations, are defined as follows:

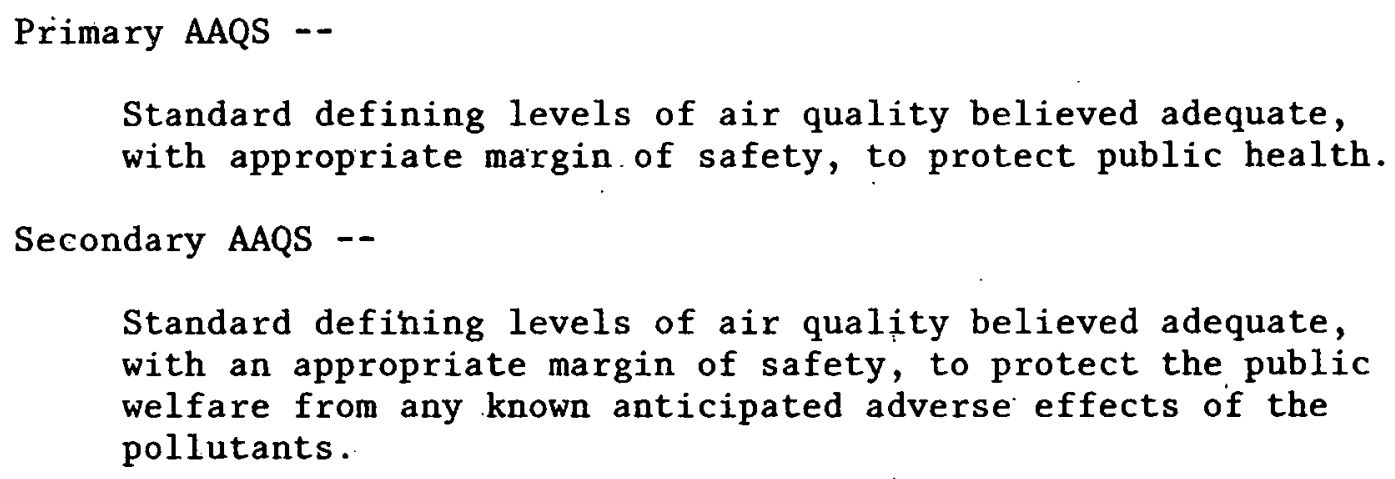

In each' of the three principal states comprising the regional study area, standards for the criteria pollutants have-been adopted that are identical. to the Federal AAQS. The applicable air quality standards for the production of uranium from Chattanooga Shale can therefore be discussed in. terms of a unified set of standards as shown in. Table XII-1. As discussed later in the characterization of regional air quality, total suspended particulates and sulfur dioxide are the principal pollutants of concern on a regional basis; however, exceedances of all six of the criteria species may occur in the heavily industrialized and urbanized major cities in.the Chattanooga Shale resource area.

\section{AIR POLLUTION EFFECTS:}

The roles of each of the criteria pollutants comprising the air quality spectrum are briefly outlined.below to provide.the basis for a discussion of existing baseline pollutant levels in the study area.

\section{Photochemical Oxidant (Principally Ozone $-0_{3}$ )}

Oxidants are formed by a complex series of atmospheric chemical reactions involving. reactive (non-methane) hydrocarbons and related organic gases and the oxides of nitrogen in the presence of sunlight. Thirty or more 
TABLE XII-1. AMBIENT AIR QUALITY STANDARDS FOR THE REGIONAL STUDY AREA

\begin{tabular}{|c|c|c|c|c|c|c|}
\hline \multirow[b]{2}{*}{ Contaminant } & \multicolumn{3}{|c|}{ Primary Standard } & \multicolumn{3}{|c|}{ Secondary Standard } \\
\hline & $\left(\mu \mathrm{g} / \mathrm{m}^{3}\right)$ & $(\mathrm{ppm})$ & $\begin{array}{l}\text { Averaging } \\
\text { Time }\end{array}$ & $\left(\mu \mathrm{g} / \mathrm{m}^{3}\right)$ & $(\mathrm{ppm})$ & $\begin{array}{c}\text { Averaging } \\
\text { Time } \\
\end{array}$ \\
\hline \multicolumn{7}{|l|}{ Photochemical } \\
\hline Oxidant & 160 & 0.08 & 1 hour & 160 & 0.08 & 1 hour \\
\hline Carbon & 10,000 & 9.0 & 8 hours & 10,000 & 9.0 & 8 hours \\
\hline Monoxide & 40,000 & 35.0 & 1. hour & 40,000 & 35.0 & I hour \\
\hline Sulfur & 80 & 0.03 & AAM & 1,300 & 0.5 & 3 hours \\
\hline Dioxide & 365 & 0.14 & 24 hours & & & \\
\hline \multicolumn{7}{|l|}{ Nitrogen } \\
\hline Dioxide & 100 & 0.05 & AAM & 100 & 0.05 & AAM \\
\hline $\begin{array}{l}\text { Non-methane } \\
\text { hydrocarbons }\end{array}$ & 160 & 0.24 & 3 hours & 160 & 0.24 & 3 hours \\
\hline 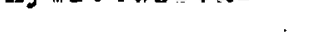 & & & $(6-9$ a.m. $)$ & & & $(6-9$ a.m. \\
\hline Total Suspended & 75 & - & AGM & 60 & - & AGM \\
\hline Particulates & 260 & - & 24 hours & 150 & - & 24 hours \\
\hline
\end{tabular}

\section{Explanatory Notes}

1. All standards except annual not to be exceeded more than once per year.

2. $\mu \mathrm{g} / \mathrm{m}^{3}=$ micrograms per cubic meter.

3. $\mathrm{ppm}=$ parts per million by volume.

4. $A A M=$ annual arithmetic mean.

5. AGM = annilal genmet.rir mean.

6. Hydrocarbon standard to be used as a guide to achieve the oxidant standard.

7. Annual particulate standard to be used as a guide to achieve the 24-hour standard. 
chemical reactions are involved in the photochemical reaction system, with another 200 reactions identified as potential contributors to the oxidant and related visible aerosol formation process.

Oxidant standards are designed to prevent impairment of pulmonary function and to prevent vegetative damage. Because of the high reactivity of the ozone molecule, it causes considerable damage to metals, rubber, synthetic fibers, etc., but the most significant damage appears to be to oxidant-sensitive agricultural crops and many evergreen tree species. Although oxidant values in a region may be relatively low, oxidant damage creates a cumulative dosage effect such that longterm low-level chronic exposures are as harmful as short-term high-level conditions. Ozone is often associated with days of heavy eye-irritation, but it is not an eye irritant in itself.

\section{Carbon Monoxide (CO)}

Carbon monoxide is a colorless, odorless, tasteless gas formed as a by-product of incomplete oxidation during the combustion process. Carbon monoxide standards are designed to prevent interference with the oxygen transport capacity of hemoglobin in blood.

\section{$\underline{\text { Nitrogen Dioxide }\left(\mathrm{NO}_{2}\right)}$}

Nitric oxide is formed by the oxidation of atmospheric nitrogen during the combustion $;$ rocess, with the rate of formation directly proportional to the combustion temperature. Nitric oxide is normally slowly oxidized in the atmosphere to form the dioxide, but the conversion rate is accelerated in highly polluted atmospheres.

Nitrogen dioxide standards are designed to prevent respiratory disease, vegetative damage, and atmospheric discoloration by the reddish-brown hue associated with the pollutant. 
$\underline{\text { Sulfur Dioxide }\left(\mathrm{SO}_{2}\right)}$

Sulfur dioxide is formed principally during the combustion of fossil fuels containing sulfur. Oxidation of the dioxide in the presence of sunlight yields a sulfur trioxide $\left(\mathrm{SO}_{3}\right)$ which combines with moisture in the air to form sulfuric acid mist or other airborne sulfate particles, each with their own associated ecological impact.

Sulfur dioxide standards are designed to prevent pulmonary irritation, to minimize vegetative damage due to leaf stomata destruction, and to prevent sulfur odor nuisance.

Non-methane Hydrocarbons (NMHC)

Atmospheric hydrocarbons are produced mainly in the processing, transport, marketing, and combustion of petroleum products, as well as from a number of natural sources. Hydrocarbons need only be partially oxidized to produce a number of undesirable health effects and degrade visibility.

Hydrocarbon standards are designed as a strategy to control subsequent oxidant formation, a process which utilizes reactive hydrocarbons as a precursor to photochemical smog formation. The reactivity of hydrocarbons ranges from almost inert to immediately convertible. Similarly, atmospheric hydrocarbons range from substances of negligible health impacts to highly irritating substance's such as peroxyacetyl-nitrates (PAN--similar to tcar gas), and to strung carcinugens such as vinÿl chlorıde.

Total Suspended Particulates (TSP)

The sources of total suspended particulates are principally natural except near highly industrialized urban centers or near extensive agricultural operations. Aerosols, 1.e., suspended solids or liquids in air, are found in a variety of sizes, shapes, and chemical compositions.

Particulate standards are designed to prevent visibility deterioration and to minimize health effects due to prolonged exposure, particularly 
to long-chain hydrocarbon molecules and airborne lead particles. Most large particulates are rejected by respiratory filtering during breathing, but particulate measurement techniques are typically not able to distinguish between total aerosol mass and the physiologically important respirable fraction.

Other Hazardous Air Pollutants

Other air pollutants are known to be hazardous to health even in low ambient concentrations. Some of these substances are subject to strongly regulated source limitations and several have hazardous-substance AAQS associated with them. Hazardous pollutants include beryllium, mercury, asbestos, vinyl chloride, fluorides, and hydrogen sulfide. There are no known problems with emissions of these contaminants in the study area except very close to, or within, some of the industrial areas that create or use these substances. Concentrations, both within an industrial hygiene environment and the ambient atmosphere, are rarely, if ever, at a level of serious concern.

\section{REGIONAL AND LOCAL AIR QUALITY}

Air quality, unlike meteorology, is not a quasi-homogeneous parameter over distances even as small as a lew miles; thus, characterizing regional pollution levels is a more difficult task. Care must be exer-cised in evaluating the results of the ambient air quality monitoring networks within the study area. Usually these measurements represent the air quality in only a small portion of the community in which the measurements were made. In fact, such monitors often are located downwind from major sources in an effort to determine the worst-case impact conditions. Since such sources are usúălly near cenlers uf industry and population, they are not representative of the largely rural sections of the Chattanooga Shale study area.

The homogeneity in regional meteorology introduces a smoothing of regional pollutant distributions with increasing distance from the isolated larger cities and major point sources. This similarity in rural dispersive 
characteristics is reflected in the fact that the study area is composed of only two major air quality control regions (AQCR's). The South Central Kentucky Intrastate AQCR merges with the Middle Tennessee Intrastate $A Q C R$ to form one interstate $A Q C R$, and the Cumberland Mountain AQCR in Tennessee continues into the Tennessee River Valley AQCR in Alabama to form the second major interstate AQCR of the study area.

Based upon the data available from the regional system of air quality monitors, the pollutants of concern in the semi-rural environs of probable Chattanooga Shale resource development are total suspended particulates and, to a lesser extent, photo-chemical oxidant, and possibly hydrocarbons. Oxidant and hydrocarbons are monitored only in selected developed areas and although the pollutant "plumes" from these regional sources may extend well into less developed areas, there is little or no monitoring resource to define the probable limits of oxidant exceedances.

Conveniently, the one pollutant that constitutes the greatest probable air quality impact from mining, milling, retorting, and other shale handling operations is the pollutant that is best represented by data on a regional scale, viz., total suspended particulates. Unfortunately, it is also the one pollutant species that most assuredly experiences a high number of AAQS standard violations. Some of these violations are due to natural phenomena such as dust storms, erosion, or fires, but a number of anthropogenic sources exacerbate the atmospheric dust problem. Major sources of dust include industrial activity, agricultural operations, fugitive dust from dirt roads or roadway dust lofted by traffic-generated turbulence (vehicle wake turbulence), home heating, open burning, and a number of others. Obtaining an accurate emissions inventory for particulates is very difficult because of the diversity of sources. Even if the sources could be identified, aerosols are formed in situ in the atmosphere in complex nucleation processes such that the source/receptor relationship will probably never be completely understood. 
Figure XII-1 depicts the location of the 57 stations used in the regional TSP characterization. Additional stations monitor TSP levels, especially in the Nashville and Chattanooga areas, but in each case the "cleanest" station in terms of 24-hour maxima was taken to be the most representative of regional conditions. The stations outside the study area boundary were used to provide additional detail in the pollutant isopleth maps. Two recent years (1975-1976) were analyzed in detail to define the areas most sensitive to the addition of further pollutant burden. Highest and second-highest 24-hour TSP levels and the annual geometric means for the 57. stations are shown in Appendix $F$ which is keyed to the station numbering system shown in Figure XII-1.

In spite of the conservative (over-predictive) tendency in preparing. regional pollutant level maps from stations near major source areas, a realistic representation of probable pollutant levels can nevertheless be obtained, particularly if increased activity associated with a largescale project causes a corresponding increase in activity level near some specified site. Although the present discussion of baseline air pollutant levels and the forthcoming discussion of probable air quality impact is structured toward uranium recovery operations, it is similarly valid for any large operation within the study area.

The annual geometric mean (AGM) is an important indicator of the probable areas of TSP problems. In Figure XII-2, the TSP levels are shown to be high along the Tennessee River, very high around the steel plants near Birmingham, Alatsma, and somewhat elevated in smaller industrialized cities in south-central 'lennessee extending as far north as Nashville. Again, the Figure does not include the very highest levels around Nashville, Chattanooga, Knoxville, and Birmingham, and also interpolates values into semi-rural areas where such interpolation is not actually valid. The important aspect of Figure XII-2 is that the area in a wide circle around DeKalb County is a probable compliance area in terms of particulates. The Cumberland River drainage area, both around Center Hill and Dale Hollow Lakes toward Lake Cumberland, appears to be extremely "clean." 


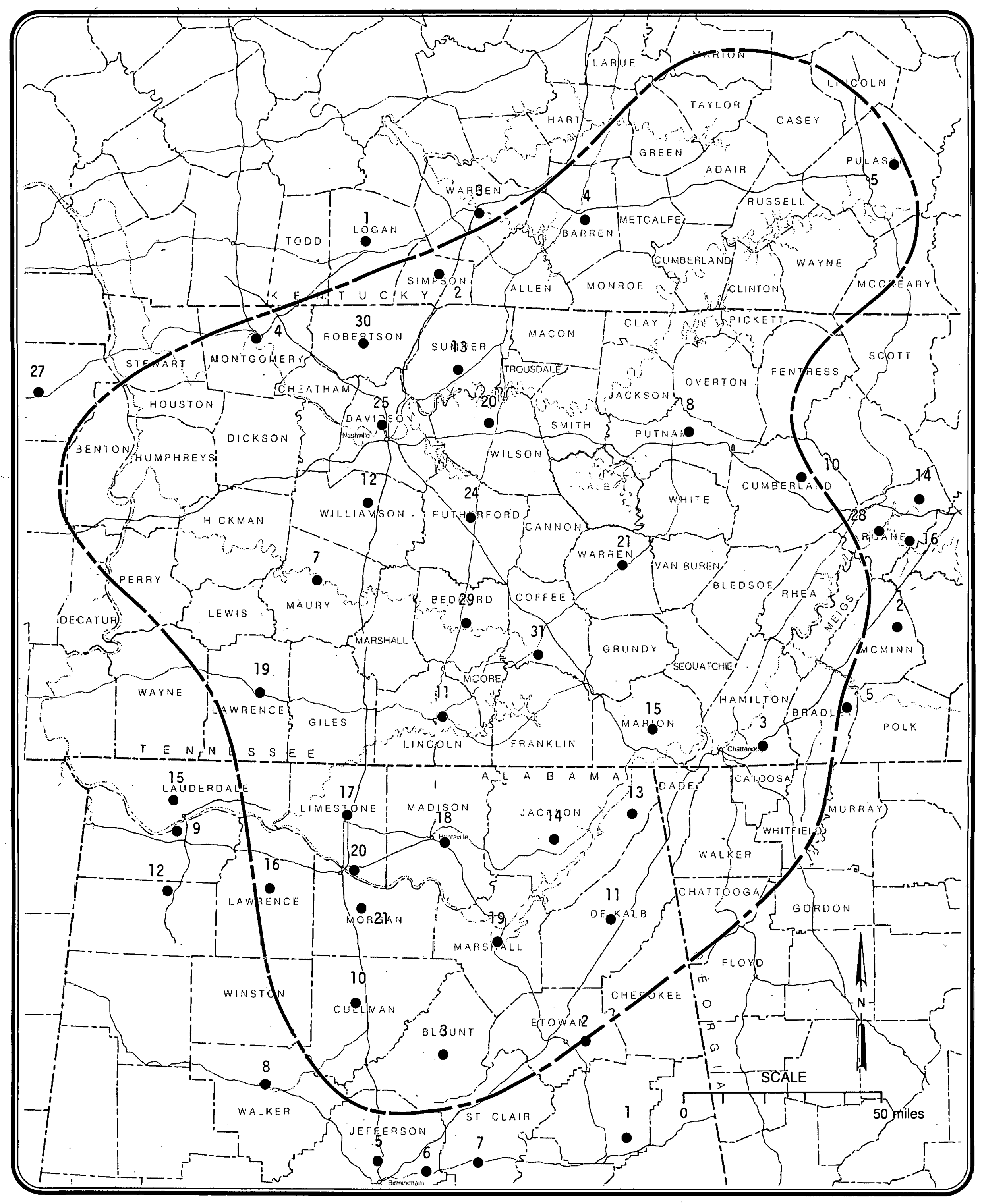

REGIONAL PARTICULATE MONITORING STATIONS IN THE REGIONAL STUDY AREA (refer to Appendix C for station identification)

$\underline{\text { KEY }}$

- Monitoring Station Location

16 Station ldentifier

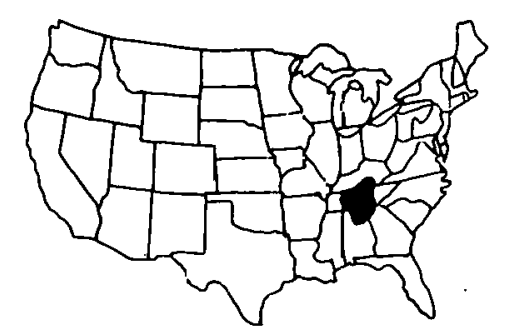




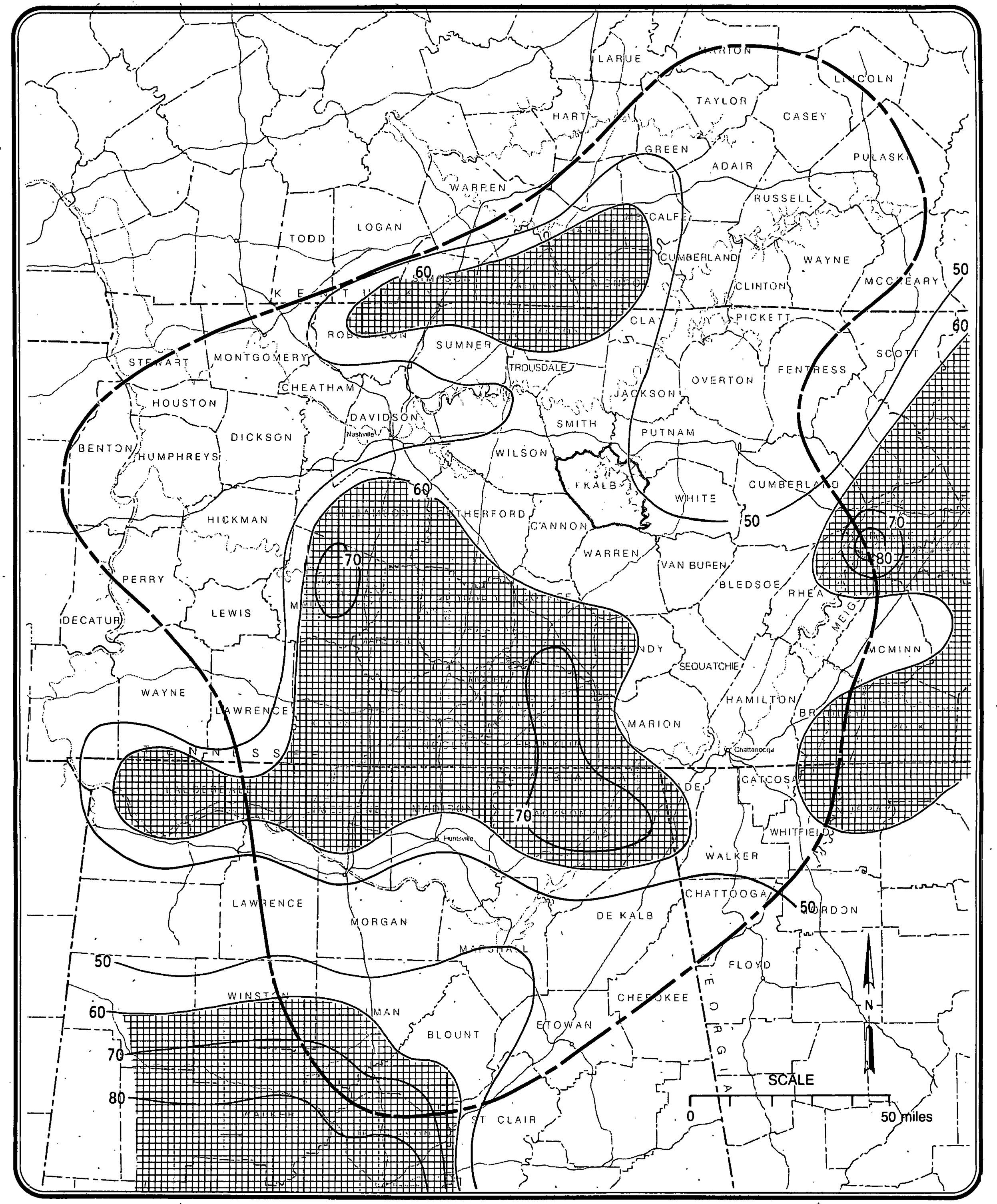

ANNUAL (1976) GEOMETRIC MEAN TSP LEVELS IN THE REGIONAL STUDY AREA (SHADED PORTIONS INDICATE WHERE THE SECONDARY NAAQS FOR PARTICULATES WERE EXCEEDED)

$\underline{\text { KEY }}$

50 TSP Levels $(\mu \dot{\mathrm{g}} / \mathrm{m} 3)$

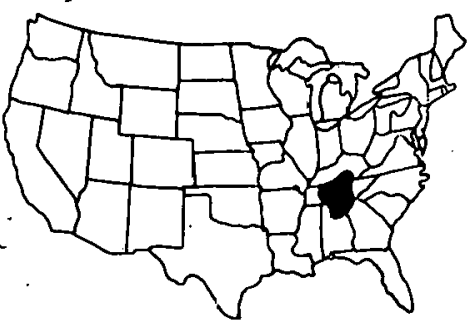




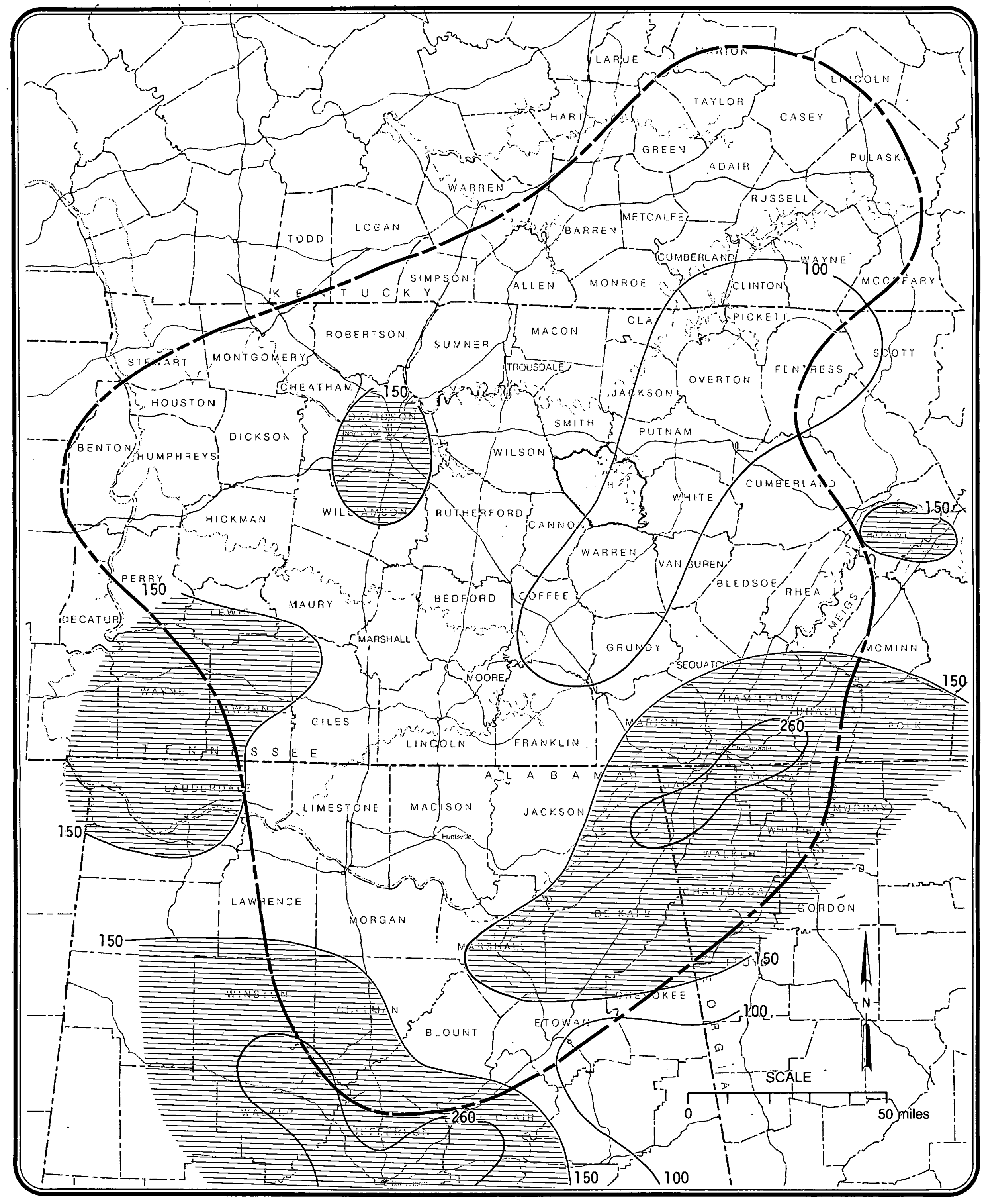

24-HOUR ANNUAL (1975) MAXIMUM TSP LEVELS IN AND AROUND THE REGIONAL STUDY AREA (SHADED AREAS INDICATE AREAS WHERE THE SECONDARY AAQS FOR PARTICULATES WERE EXCEEDED)

KEY

150 TSP Levels $(\mu \mathrm{g} / \mathrm{m} 3)$

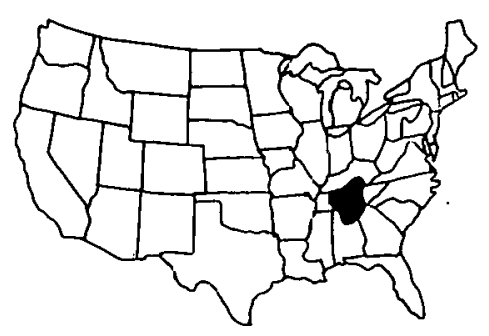




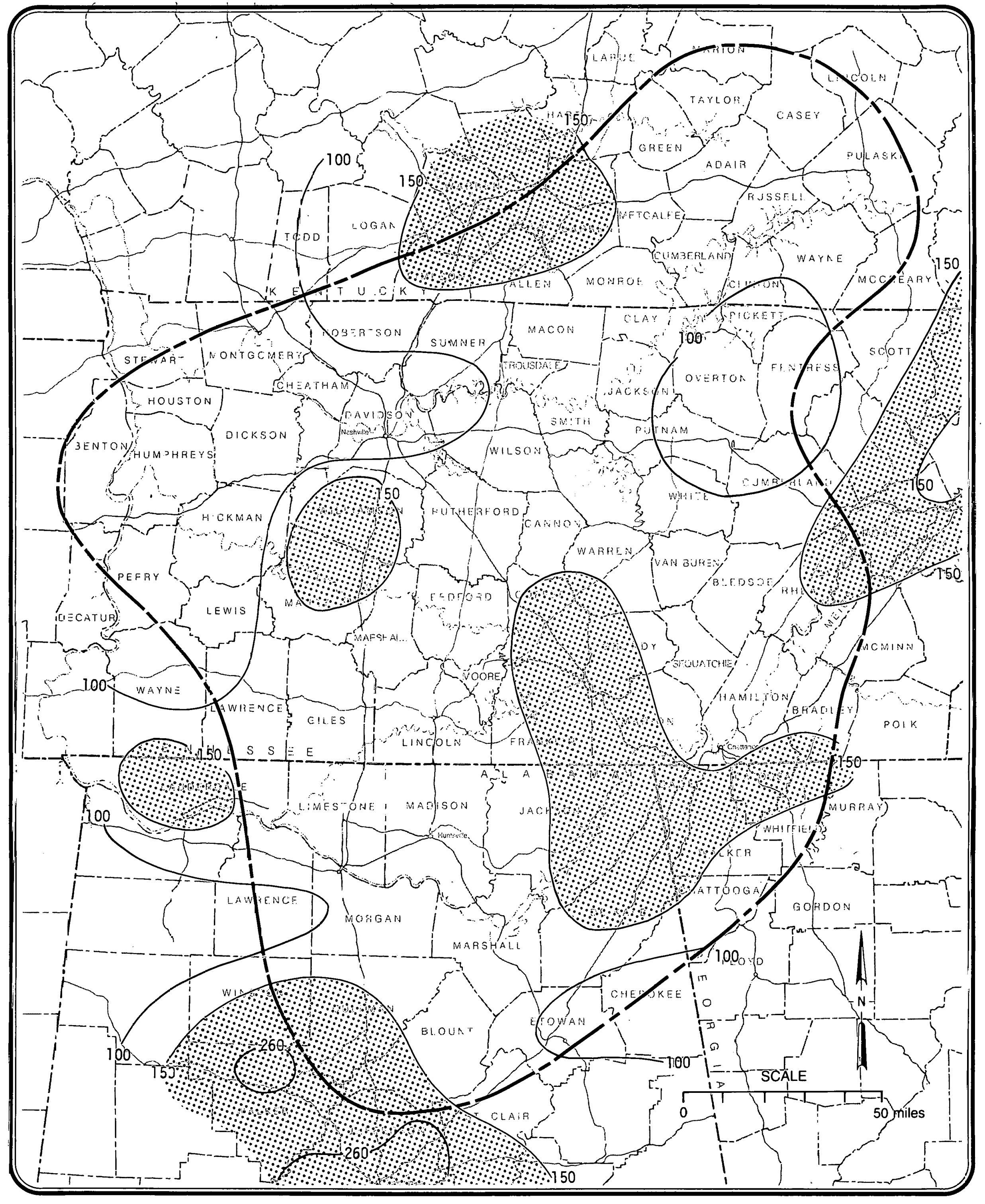

24-HOUR ANNUAL (1976) MAXIMUM TSP LEVELS IN AND AROUND THE REGIONAL STUDY AREA (SHADED AREAS INDICATE AREAS WHERE THE SECONDARY AAQS FOR PARTICULATES WERE EXCEEDED)

KEY

150 TSP Levels $(\mu \mathrm{g} / \mathrm{m} 3)$

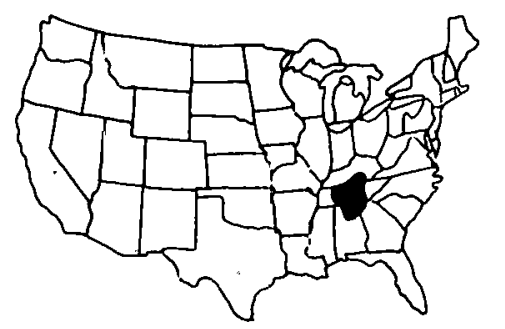


The fact that the AGM is an indicator of the areas where the 24-hour standard is threatened suggests an examination of daily TSP distributions. Distributions for 1975 and 1976 detailed in Figures XII-3 and XII-4 verify the use of the secondary AAQS value of $60 \mathrm{mg} / \mathrm{m}^{3}$ AGM as a guide to achieving the 24-hour standard. In both cases, the Tennessee River Valley, the Birmingham area, and certain isolated areas of Tennessee and Kentucky show the most significant pollutant levels. Primary 24-hour standard violations $\left(260 \mathrm{mg} / \mathrm{m}^{3}\right)$ are confined to areas around Birmingham, Chattanooga, and sometimes northeastern Tennessee, but secondary standard violations are rather widespread. It should be noted that the secondhighest maximum is the value to be compared against the AAQS. However, since particulates are routinely monitored every sixth day, there is a distinct possibility that the true annual maximum was not really sampled and thus Figures XII-3 and XII-4 are a good guideline for areas of current TSP problems.

As with the AGM, the 24-hour values also point out that central Tennessee around DeKalb County has very low TSP levels in the atmosphere. Particulate levels around northern Alabama increase rapidly in moving toward the major sources of Jefferson County. Although Oneonta, Alabama shows levels slightly below the AAQS, the AGM and 24-hour maxima are rather close to the standard. Similarly, southern Kentucky has slightly higher levels, indicating greater particulate loading in that portion of the study area. Franklin, Bowling Green, and Glasgow, Kentucky all have experienced levels above the secondary standard. To what extent the values measured in the larger cities are applicable to the surrounding cuuntryside could be confirmed only by supplemental monitoring, nonetheless the interior of the study area shows all indications of being well-suited for additional industrial development from present air quality considerations.

\section{AIR QUALITY TRENDS}

Since the operational date for the large-scale recovery operation herein contemplated is probably more than 10 years away, the implications of current AAQS violation patterns to such a projert are problematic. As 
each state has filed a state implementation plan (SIP) to achieve and maintain AAQS well within the anticipated project time-frame, the foregoing discussion must be extrapolated at least one decade forward.

Progress toward cleaning up the environment has been dramatic in the early 1970s, but is currently slowing due to technological constraints and a lack of strong commitment by a public whose jobs and well-being are seemingly threatened by further pollution control. Figure XII-5 indicates the progress toward statewide standard attainment in Tennessee. While the failure of the curve to continue the downward trend in 1976 is of some concern, it points out the importance of the variation in meteorological parameters that often govern the variation in air quality. Another possible cause of the halt in downward movement of the trend is the possible distortion of the overall picture by localized sources such as temporary construction or maintenance activities. Changes in land use over a period of time may destroy any representativeness that a station once may have had. Although the annual trend in Figure XII-5 is proceeding asymptotically toward attainment, the high degree of variability in the controlling factors may cause TSP-standard attainment to be delayed beyond the 1990 target date for Chattanooga Shale resource development activities.

As indicated above, the decline of public support may seriously impair further significant progress toward complete attainment. Strategies are already shifting from pressure upon all industries to concentration upon the major polliters which constitute a more "viable" target. Delays in the compliance schedule by affected industries, similar to the delays requested by the automobile industry in meeting future emissions standards, will slow the trend toward clean air. With respect to expected TSP levels in the next decade, it may be assumed that they will be lower than today, but it is also reasonable to expect that small pockets of non-compliance will continue to exist.

Since the relationship betwen natural and man-made pollutants in causing violations of the photochemical oxidant standards is not completely understood, some doubt as to future attainment of the oxidant standard 
TENNESSEE TRENDS IN TSP STANDARD VIOLATIONS INDICATING PROGRESS TOWARD ZERO EXCEEDANCES

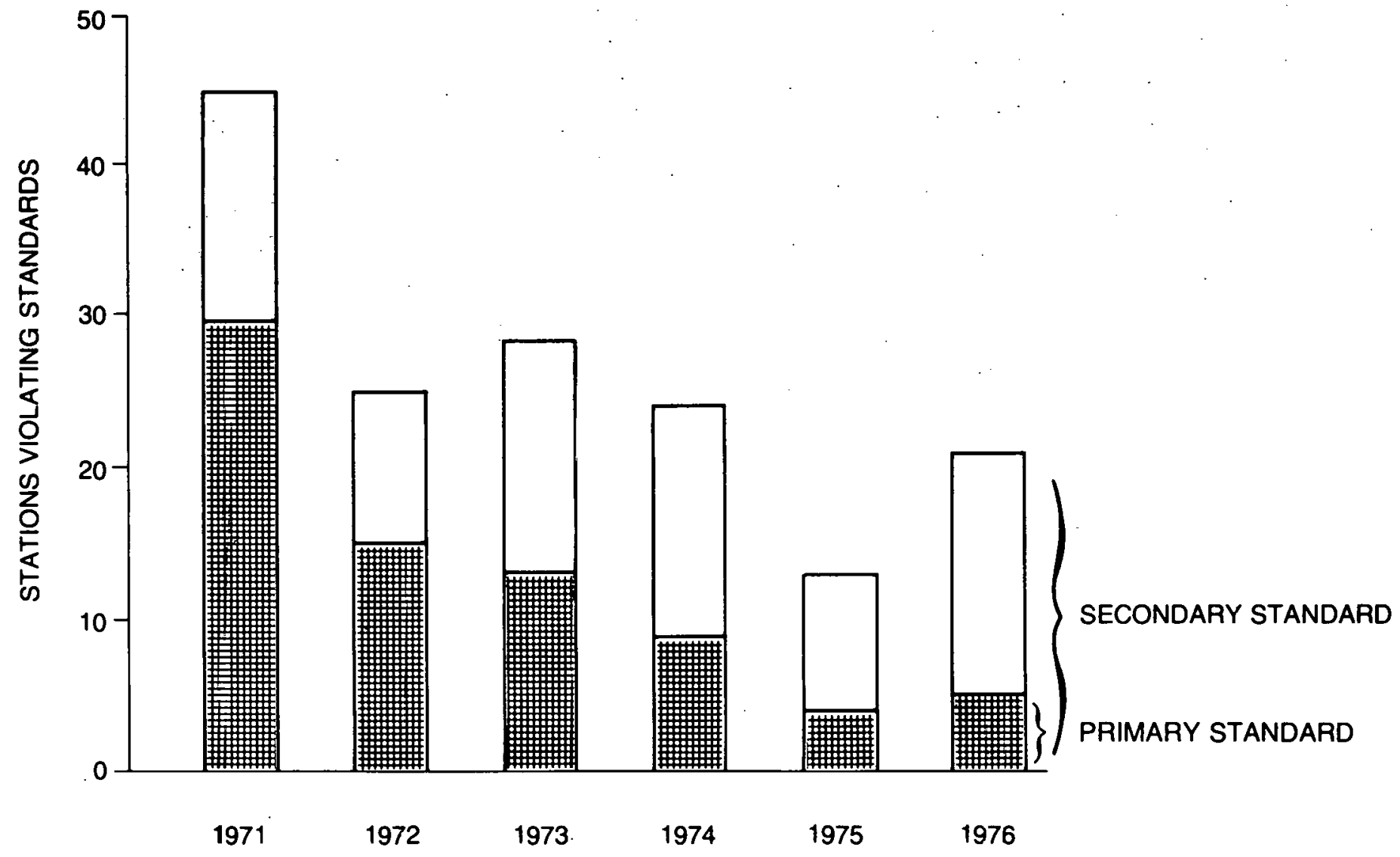

FIGURE XII-5 
also exists. The EPA strategy to control hydrocarbon emissions may not be useful in situations where the hydrocarbon to oxides of nitrogen ratio is not optimized for effective resultant oxidant control. Each ozone monitoring station in Tennessee currently indicates violations of the oxidant AAQS. Without significant scientific or technological breakthroughs, further threatening of the standard well into the future may also be anticipated. Again, such violations may be of a highly localized nature well away from the probable shale development area. Given the current attainment status of most or all the criteria pollutants in much of the area under consideration for shale processing, it is reasonable to expect that the development could be established in AAQS attainment areas that have a significant margin of safety for accepting some additional project-related pollutants.

\section{ANALYSIS OF IMPACTS}

The following analysis relies heavily upon the description of the prototype project outlined in Section VII, and the reader is encouraged to review that discussion accordingly. Atmospheric emissions associated with the total recovery operation comprise those associated with three major activity rategories: 1) extraction and materials handling for uranium remova1, 2) hydroretorting for oil removal, and 3) activities arising from project-stimulated general growth of the area around the facility.

\section{AIR POLLUTANT EMISSIONS ESTIMATION}

In order to contemplale the potential environmental impacts of atmospheric emissions produced by the operation in question, it is necessary to quantify those emissions to the extent possible. Since plants that process 100,000 tons of ore per day to recover $3+$ tons of uranium and 50,000 barrels of oil have never been built, emission factors for such activities are obviously poorly defined. Factors used in the subsequent analysis have been "scaled up" from much smaller system throughputs and such scaling may not be correct for much larger plants. Until engineering designs and pilot plants are completed, linearly scaled estimates will nonetheless have to suffice. 
The following emissions estimation analysis considers separately the three major source categories identified above: 1) shale ore-handling emissions, 2) hydroretorting refinery emissions, and 3) project-related emissions.

\section{Shale Ore-Handling Emissions}

Ore-handling emissions are considered herein to constitute all discharges to the atmosphere associated with extraction of the ore from the earth, processing the ore for uranium recovery, and disposal of spent shale wastes.

Emissions within the mine include particulate emissions from blasting, loading, primary crushing, and the conveyor system, while gaseous pollutants are generated by the loaders and trucks that are used to load and haul the ore from the mining face to the crusher and conveyor.' The escape of radon gas and associated daughter products is a concern in mining uranium ores, and special precautions must be taken to control its accumulation in the mine, and significant exposure to the population at the site boundary. Additional emissions may be associated with backfilling of the processed shale, but present technology indicates that the spent shale will be returned to the mines as a wet slurry that would not have any air pollution implications during the disposal process. Surface disposal by containment or reclamation and revegetation will account for the shale not backfilled. Pollutants, both fugitive dust from dry material and vehicular pollutants from materials handling equipment, are important concerns in this disposal process..

Four main categories of emissions, from the initial blasting to the delivery of suitably crushed shale to the hydroretorting facility and its subsequent return from the acid leach for backfilling or surface disposal, are considered below. These four sources are: 1) blasting and initial crushing for conveyor transport; 2) secondary crushing and sizing; 3) miscellaneous fugitive dust sources during materials handling and movement; 4) principally gaseous pollutants from heavy-duty vehicles. 
Total pollutant emissions have been derived from a prototype EPA document [EPA 1976] that considers a similarly-sized shale mining and processing emissions module. Variations introduced by the unique aspects of Chattanooga Shale processing have been incorporated and are detailed in the assumptions for each of the four major emission sources.

\section{Blasting and primary crushing}

Emissions generated within the mine will be carried out in the ventilation air. In order to minimize the potential dangers of accumulations of $\mathrm{H}_{2} \mathrm{~S}$, methane, or radon gas (all serious concerns in this underground mining operation), a large ventilation volume of $3,000,000$ cfm has been assumed during maximum mining activity. Through the use of dust palliatives (i.e., water spray principally) the ambient dust level in the the mine will be maintained at or below the federally-mandated industrial hygiene level of $2 \mathrm{mg} / \mathrm{m}^{3}$. Under worst-case assumptions of maximum levels in the airstream with 24 hours of operation, 540 pounds of particulates will be emitted from the mine each day.

\section{Secondary Crushing and Screening Operations}

Secondary or tertiary crushing and sizing will result in further particulate emissions as the ore is broken down to about 1/4-inch size for hydroretorting and leaching. The EPA's "Compilation of Air Pollutant Emission Factors, AP-42" indicates 0.6 pounds per ton of emitted suspended solids for the secondary phase, and 3.6 pounds per ton for a third crushing and screening. It is atsumed that these operations will be enclosed and a baghouse with a minimum recovery efficiency of 99.7 percent will control these emissions, although recovery efficiencies of 99.9 percent are possible with present baghouse technology.

The resulting emissions from 100,000 tons of daily throughput are 1,260 pounds per day. These emissions may be considerably reduced if the ore is crushed wet instead of dry, but wet crushing usually creates problems with material handling. Water functions well to reduce particulate eirissions after the crushing and screening stage, but the ore must be handled as dry as possible up to the leaching stage. 


\section{Fugitive Emissions}

Fugitive dust sources result from loose material exposed to the airstream in the conveyor system, the above-ground disposal areas, unpaved roads at the various mine sites, material stockpiles, spillage, control equipment malfunctions, etc. Such emissions are typically very difficult to quantify because neither the exact layout, handling procedures, or emission factors are well known. Using the value from the EPA-commissioned study for oil shale handling scaled to the 100,000 tons/day of ore processed, the resulting fugitive dust emissions total 300 pounds/day.

\section{Vehicular Gaseous Emissions}

Gaseous emissions will result from the operation of mobile machinery using internal combustion engines. Twenty-ton trucks have been assumed as carriers of the shale from the blast face to the primary crusher which then loads the shale on the conveyor to the surface. Wheeled loaders have been assumed as the initial loaders of these trucks. Diesel fuel consumption has been assumed for the short-haul trucks at 5 gallons per hour, and for the loaders at 10 gallons per hour.

The emission factors and resulting emissions from mobile sources within the mine are given in Table XII-2. Using 25 heavy-duty vehicles during 24-hour operations results in the emission of slightly over 1 ton of gaseous pollutants (mainly oxides of nitrogen) into the airstream. Based upon the ventilation rate assumed for the mine, the resulting $c 0$ concentration in the mine exit airstream is $1 \mathrm{ppm}$ by volume, $\mathrm{SO}_{2}$ is 0.4 $\mathrm{ppm}$, and NO is $4.8 \mathrm{ppm}$. Since NO is not a criteria pollutant but only becomes a problem after its conversion to $\mathrm{NO}_{2}$, the $1 \mathrm{ppm}$ of $\mathrm{CO}$ and 0.4 $\mathrm{ppm}$ of $\mathrm{SO}_{2}$ represent the major impact upon the mine workers. These levels are well within industrial safety standards indicating that the assumed ventilation rate is more than adequate to control vehicular-related pollutant levels in the mine and the ventilation airflow. 
TABLE XII-2. GASEOUS POLLUTANT EMISSIONS FROM HEAVY-DUTY DIESEL-POWERED EQUIPMENT IN THE SHALE.MINES

\begin{tabular}{|c|c|c|c|c|c|}
\hline \multicolumn{6}{|c|}{ Emission Factors (非/10 3 gallons) } \\
\hline & & $\mathrm{CO}$ & $\mathrm{NO}_{\mathbf{x}}$ & THC & SO2 \\
\hline \multicolumn{2}{|c|}{ Wheeled Loaders } & 95.4 & 408.0 & 32.3 & 31.2 \\
\hline \multicolumn{2}{|c|}{ Hauling Trucks } & 92.2 & 524.0 & 30.0 & 31.2 \\
\hline \multicolumn{6}{|c|}{$\begin{array}{l}\text { Total gallons used per } \\
3,600 \text { gallons per day }\end{array}$} \\
\hline \multicolumn{6}{|c|}{ Resulting emissions (非/day) from in-mine trucks and loaders } \\
\hline $\mathrm{CO}$ & 340 非/day & & & & \\
\hline $\mathrm{NO}_{x}$ & - 1,750 非/day & & & & \\
\hline THC & 110 非/day & & & & \\
\hline $\mathrm{SO}_{2}$ & 110 非/day & & & & \\
\hline
\end{tabular}


Total Ore Handling Emissions

In extracting, crushing, and delivering 100,000 tons of shale ore to the processing plant, the total related air pollutant emissions amount to approximately 2 tons/day, half particulate and half gaseous pollutants, as summarized in Table XII-3. As disclosed below, the mining aspects of the proposed project are expected to be responsible for far less pollutants than the oil extraction module of the project.

\section{Hydroretorting Refinery Emissions}

Since oil recovery requires combustion of fuel for retorting and refining operations, far more pollution emissions will be associated with the heat treating and fractional distillation processes than with the shale ore mining itself. Refinery emissions result from stacks as well as fugitive losses from valves, pipes, connectors, heat exchange surfaces, etc. Emissions from the oil recovery operation will potentially be very significant because of the high sulfur content of most Devonian and Mississippian shale deposits. While sulfur recovery in a sulfuric acid plant is desirable for leaching the uranium.from the ore, oxidation of sulfur to $\mathrm{SO}_{2}$ or the formation of $\mathrm{H}_{2} \mathrm{~S}$ both represent serious. air quality concerns.

The refinery operations will extract the hydrocarbon resource to form either a synthetic oil or substitute natural gas. Most fuel requirements for the refinir.o process will be met by the organic content of the shale itself. The core of the process is that retorting the shale in a high pressure pure hydrogen atmosphere (hydroretorting) increases the oil yield by 250 percent over conventional assay predictions.

Feedstock for the hydrogen plant will also be derived from the shale resource; water and some treatment chemicals and catalysts will be the principal make-up requirements of the refinery process. Emissions from refining depend strongly upon the amount by hydrocarbon splitting (cracking), uniting (polymerization), or rearranging (reforming) that is required after the retorting step. Blending, treating, wastewater separation, 
TABLE XII-3: TOTAL POLLUTANT EMISSIONS FROM 100,000 ton/day SHALE MINING PROCEDURES

\begin{tabular}{lccccc}
\hline \multicolumn{1}{c}{ Source } & & \multicolumn{3}{c}{$\begin{array}{c}\text { Pollutants Emitted } \\
\text { (lbs/day) }\end{array}$} \\
\hline & TSP & CO & NO & THC & SO \\
\cline { 2 - 6 } & 540 & - & - & - & - \\
Blasting and Primary Crushing & & & & & \\
$\begin{array}{l}\text { Secondary and Tertiary } \\
\text { Crushing and Screening }\end{array}$ & 1260 & - & - & - & - \\
$\begin{array}{l}\text { Misc. Fugitive Sources } \\
\text { Mobile sources in the mine }\end{array}$ & 300 & - & - & - & - \\
\hline \begin{tabular}{l} 
Total \\
\hline
\end{tabular} & neg. & 340 & 1750 & 110 & 110 \\
\hline
\end{tabular}


and other operations all may contribute to the emissions of principally hydrocarbons and $\mathrm{SO}_{2}$, such that the refinery will potentially create the maximum air quality impact of the project.

Since the project description for refinery operations has not proceeded much beyond a conceptual framework of hydroretorting on a large scale, emissions characteristics will be difficult to define. Used as a model herein is the emission module from the western oil shale recovery plants for the Green River formation in Colorado, Utah, and Wyoming for a 50,000 bpd plant. Assuming maximum allowable emissions for combustion of some of the low-BTU off-gases from the retorts and maximum allowable emissions from the acid plant that converts elemental sulfur to sulfuric acid for uranium leaching, a suitable emissions inventory for the proposed refinery operations can be derived.

In both major pollution sources, retort heating and the sulfuric acid plant, $\mathrm{SO}_{2}$ is by far the worst pollutant. Based upon total throughput for the proposed facility, $\mathrm{SO}_{2}$ emissions may be as high as 36 tons per day emitted from two major groups of stacks at about 60 meters above the ground. These values assume 60 pounds of elemental sulfur per ton of shale are recovered and converted to $\mathrm{H}_{2} \mathrm{SO}_{4}$ for leaching operations, for a total daily sulfuric acid generation of 180 pounds per ton of shale processed (18 million pounds of $\mathrm{H}_{2} \mathrm{SO}_{4}$ per day). Sulfur recovery from the process tail gas and pretreatment of the combusion gas to reduce its $\mathrm{H}_{2} \mathrm{~S}$ concentration will be used to keep the total plant $\mathrm{SO}_{2}$ emissions at the 36 tons per day just noted.

Combustion processes also emit various oxides of nitrogen for which only limited control or removal procedures are known. Although most of the "fresh" emissions are as nitric oxide (NO), the oxidation of NO in the atmosphere, particularly in conjunction with photochemical processes involving hydrocarbons, rapidly creates the more stable and harmful pollutant, nitrogen dioxide $\left(\mathrm{NO}_{2}\right)$. By convention, total emissions of NO $+\mathrm{NO}_{2}$ are designated $\mathrm{NO}_{x}$, but the degree of potential impact depends largely upon the transport and residence time of the $\mathrm{NO}_{\mathrm{x}}$ in the atmosphere under consideration. Combustion of retort off gases in the presence 
of air will produce about 5 tons of No $x$ per day. Improvements in burner design, flue gas recirculation to limit excess oxygen, and other temperature control procedures in the burn zone may reduce that total slightly, but the inert nature of nitrogen renders it rather immune to treatment processes.

Carbon monoxide and hydrocarbons are also potential species emitted from the refinery. Until processes are further defined, their exact emission rate cannot be determined. Although good engineering practices will keep these emissions at manageable levels, the role of hydrocarbons in the formation of oxidant is an important project consideration that will require further analysis in the future.

\section{Project-related Emissions}

In addition to the unique point sources identified with the potential development, a set of secondary emissions will arise both from the general growth of the area around the facility and the vehicular emissions resulting from the large construction and labor force required to sustain the project. The emissions from the mobile sources can be roughly quantified, but the effects of satellite growth are impossible to prescribe before a county developmental master plan with attendant land use patterns is established.

Calculation of project-related emissions using the population projections of Section XIII and approximate traffic pattern figures indicated in Table XII-4 produces the unique result that almost a four-fold increase in traffic between now and 1995 for the proposed project is almost exactly balanced by a concurrent reduction in vehicle emissions during that time. The net change is almost zero. Except for the oxides of nitrogen (tailpipe improvements are not forecast to be as dramatic as improvements applying to the other two species), the total county burden of vehicular pollutants is not expected to be much different in 1995 than in 1977 , even with a project of the magnitude anticipated herein. 
TABLE XII-4. APPROXIMATE VEHICULAR EMISSIONS FROM PROJECT-STIMULATED GROWTH IN DEKALB COUNTY

Design assumptions:

ATL (average trip length) - 6 miles/trip

Trip generation factor - 2.5 trips/person/day

VMT (vehicle miles traveled)

Currently - 180,000 miles/day

Construction Phase [a] - 553,000 miles/day

Operations Phase [a] - 645,000 miles/day

Pollutants generated:

\begin{tabular}{|c|c|c|c|}
\hline & $\begin{array}{c}\text { Total } \\
\text { Hydrocarbons }\end{array}$ & $\begin{array}{l}\text { Carbon } \\
\text { Monoxide }\end{array}$ & $\begin{array}{l}\text { Oxides of } \\
\text { Nitrogen }\end{array}$ \\
\hline $\begin{aligned} \text { Currently } & \text { (非/day) } \\
& \text { (tons/year) }\end{aligned}$ & $\begin{array}{r}1786 \\
326\end{array}$ & $\begin{array}{l}8730 \\
1593\end{array}$ & $\begin{array}{r}1468 \\
268\end{array}$ \\
\hline $\begin{aligned} & \text { Construction Phase } \text { (非/day) } \\
& \text { (tons/year) }\end{aligned}$ & $\begin{array}{r}1951 \\
356\end{array}$ & $\begin{array}{l}8534 \\
1557\end{array}$ & $\begin{array}{r}2682 \\
489\end{array}$ \\
\hline $\begin{aligned} & \text { Operations Phase } \text { (非/day) } \\
& \text { (tons/year) } \\
&\end{aligned}$ & $\begin{array}{r}1565 \\
286 \\
\end{array}$ & $\begin{array}{l}7542 \\
1376 \\
\end{array}$ & $\begin{array}{r}2846 \\
579 \\
\end{array}$ \\
\hline
\end{tabular}

[a] Includes commuters from outside DeKalb County. 
Table XII-4 also points out that delays in implementing additional stringent standards of automobile performance will reduce the effectiveness of the automobile emissions control program. Obviously, more detailed traffic analyses would be necessary in the future, but based upon present rough projections, no significant air quality impact from traffic would be anticipated as the particular result of the Chattanooga Shale resource recovery project.

\section{AMBIENT AIR QUALITY IMPACT}

Having established an approximate total air quality burden for the development of the shale resource, those emissions will now be discussed in terms of their impact upon ambient air quality. As discussed earlier, AAQS have been established for ambient air; the prevention of significant deterioration (PSD) concept and regulatory agency enforcement powers discussed in Section XIV center principally upon the requirements for emissions sources not to violate air quality standards. The three major impacts considered above: 1) particulates from mining and materials handling; 2) $\mathrm{SO}_{2}$ from combustion and acid plant sources; 3 ) $\mathrm{CO}$ from increased traffic, are analyzed below in terms of their ambient air quality impact, by means of point and line source diffusion models. Although total traffic emissions have been shown not to increase, the redistribution of the traffic pattern along a potential thoroughfare in and out of the plant complex is assessed below to determine the co impact immediately adjacent to the roadway.

Particulate Dispersion

In order to determine the average annual air quality impact of 2100 pounds/day of particulates emitted from the dust control equipment, the Gaussian Bivariate Equation [see Turner 1970] has been merged with the Smithville, Tennessee STAR meteorological data to generate the yearly average dilution factors for slightly elevated releases. The release height from the fan and baghouse exhausts plus the minimal plume rise has been assumed to yield an effective stack height of 30 meters ( $~(100$ feet) that has been assumed to remain constant for the entire set of calculations. 
The integrated concentration at any given distance from the stack with a directional frequency it is given by the formula,

$$
X=Q \sum_{j=1}^{5} \sum_{k=1}^{8} \mathbf{f}_{j, k}(X / Q)_{j}, k \text {, }
$$

where $j$ is the speed ranges ( 5 speed groups), $k$ is the stability class (8 classes, including a split of the day and night neutral cases), and $(X / Q)_{j}, k$ at any distance is calculated from dispersion curves in Turner's Workbook, or a similar compilation. The values of $X / Q$ for a low-level particulate source in DeKalb County are given in Table XII-5. Figure XII- 6 shows the resulting pattern if one assumes a constant emission rate of $10.5 \mathrm{~g} / \mathrm{sec}(\sim 2000 \mathrm{lb} /$ day $)$ of dust lofted into the atmosphere that does not immediately settle back out, i.e., remains suspended and travels as a passive contaminant. The maximum contribution of $5 \mu \mathrm{g} / \mathrm{m}^{3}$ occurs $5.5 \mathrm{~km}$ ( $\sim 3 \mathrm{miles}$ ) north of the prototype plant site, the TSP increase in Smithville is predicted to be $2.5 \mu \mathrm{g} / \mathrm{m}^{3}$. The maximum impact represents a contribution of about 8 percent of the Federal AAQS for particulates; the Smithville total represents about 4 percent. Both cases are acceptable levels of impact since the area currently is an attainment area for particulate standards and the predicted impacts are not sufficient to cause violation of these standards.

\section{$\underline{\text { Refinery Plume SO }} 2$ Dispersion}

While particulates are emitted from low-level stacks producing nominal buoyancy, refinery emissions will generally be associated with taller stacks ( ${ }_{50}$ meters stack height) and buoyant plumes. By assuming certain plant parameters, one can compute plume rise from a compendium of formulae presented by Briggs [1969], and others, and incorporate changing plume height into the dispersion equations. Calculations similar to the particulate impact thus have been performed for 36 tons of $\mathrm{SO}_{2}$ emitted each day from elevated sources. 
TABLE XII-5. AVERAGE ANNJAL DISPERSION FACTORS $(\chi / Q)$,

( $\left.\mu \mathrm{sec} / \mathrm{m}^{3}\right)$, for Smithville, Tennessee--(low-level emissions)

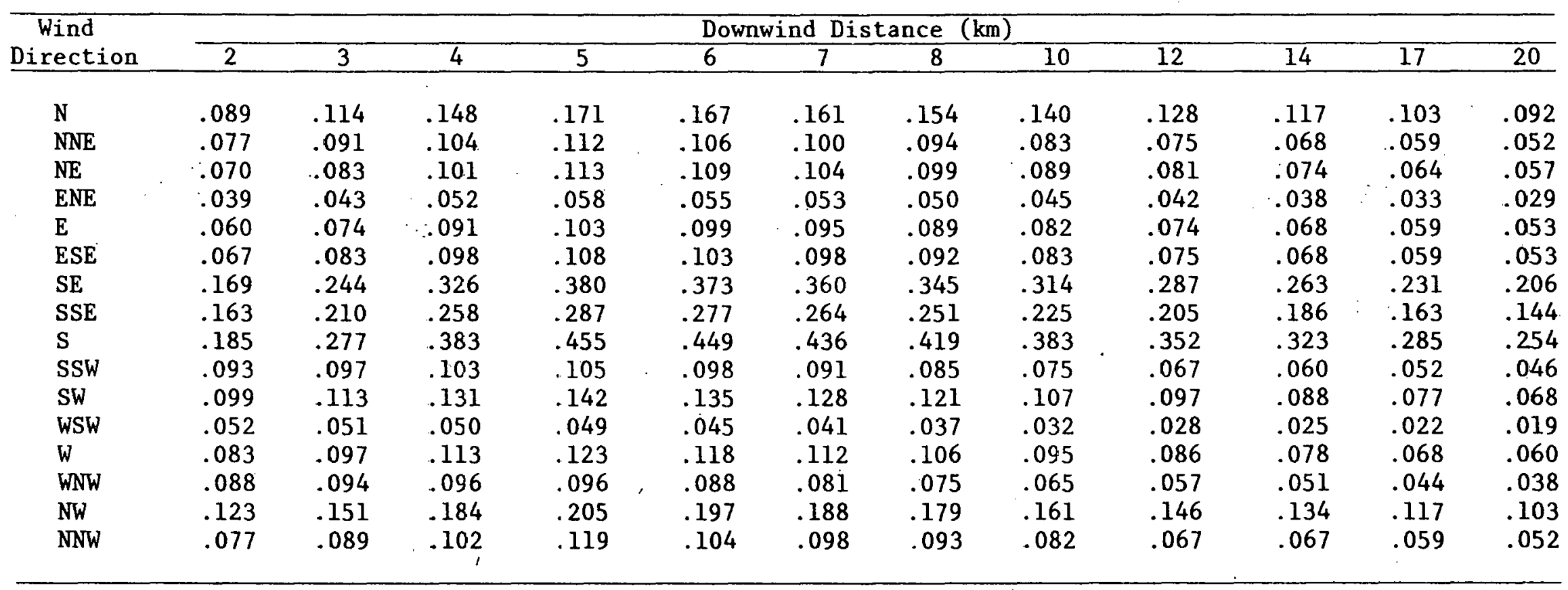




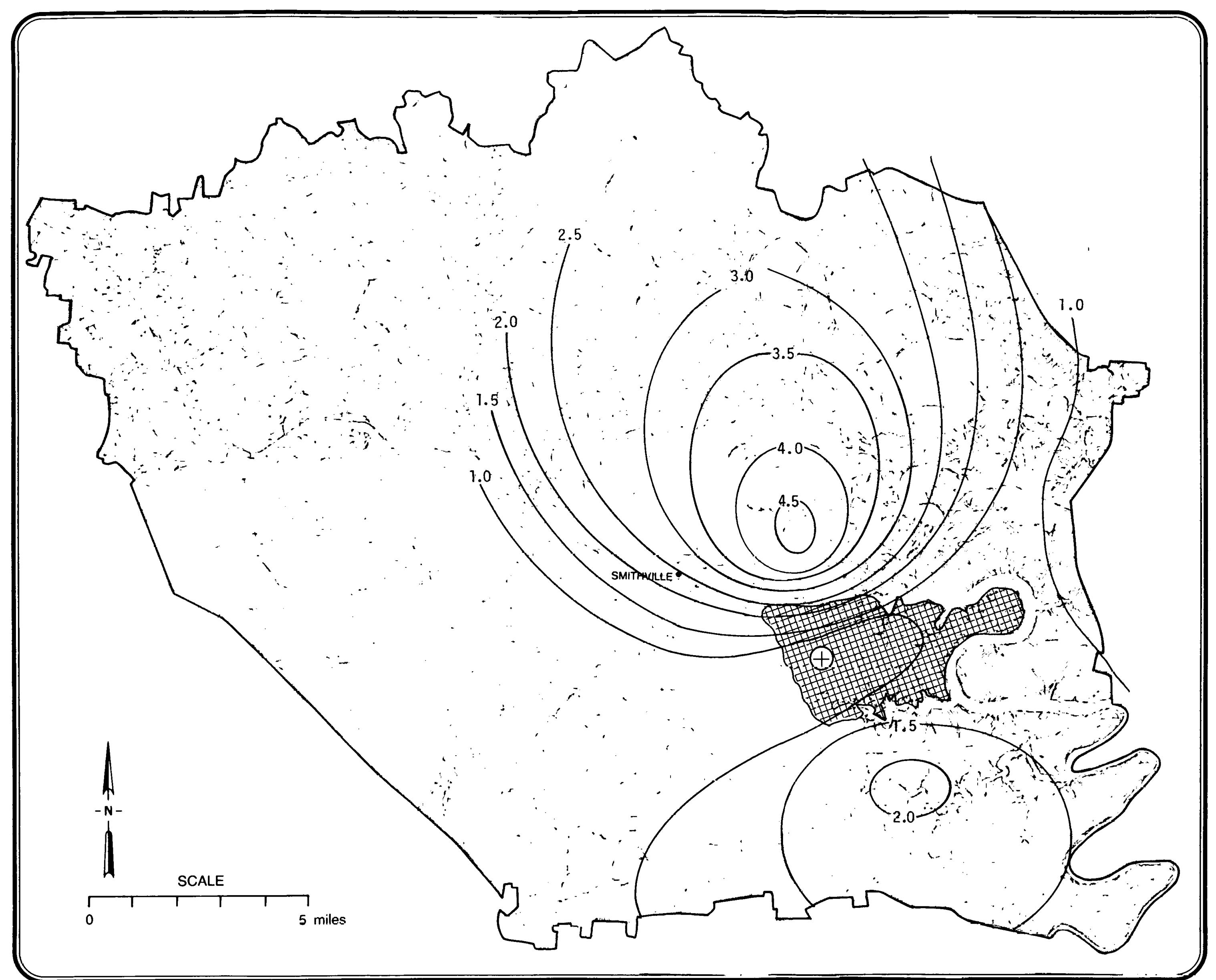

DISPERSION PATTERN FOR ONE TON PER DAY OF PARTICULATES

EMITTED FROM CHATTANOOGA

SHALE MINE AND PROCESSING OPERATIONS $(\mu \mathrm{g} / \mathrm{m} 3)$

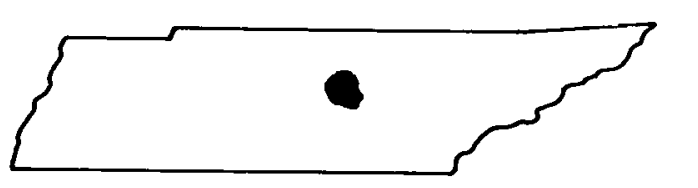

$\oplus$ Source

Prototype Project

FIGURE XII-6 
Results of the $\mathrm{SO}_{2}$ impact analysis show similar locations of the downwind maximum, but the mechanism for impact is slightly different. Particulates experience maximum impact under neutral conditions with light winds that maintain the integrity of the plume. For the elevated refinery plume, maximum impact occurs when moderate breezes somewhat suppress plume rise and slightly unstable conditions accelerate diffusion toward the ground. Figure XII-7 shows the anticipated $\mathrm{SO}_{2}$ pattern resulting from the refinery emissions. The annual average $\mathrm{SO}_{2}$ impact of slightly over $20 \mathrm{~g} / \mathrm{m}^{3}$, or 25 percent of the annual standard, occurs $3-4 \mathrm{~km}$ north of the plant site, with values in Smithville of $10 \mathrm{~g} / \mathrm{m}^{3}$. The one-hourly maximum of $350 \mathrm{~g} / \mathrm{m}^{3}$ which occurs at the plant boundary is much less than the 1300 $\mathrm{g} / \mathrm{m}^{3}$ three-hour AAQS secondary standard and even less than the 24-hour standard of $365 \mathrm{~g} / \mathrm{m}^{3}$.

It would appear that the $\mathrm{SO}_{2}$ plumes will not seriously impair maintenance of AAQS if the baseline $\mathrm{SO}_{2}$ standards are shown by measurement to be currently met. Although $\mathrm{SO}_{2}$ will ultimately convert to sulfate aerosol or sulfuric acid mist, and contribute to the overall sulfate problem in the eastern United States, its impact in the more immediate vicinity will be within allowable standards.

\section{Roadway Emissions Impact}

In order to estimate the impact of vehicular emissions adjacent to a major thoroughfare in and out of the plant, a worst-case set of meteorological and roadway utilization conditions have been used to initialize a line suucie disperaion model. As previously discussed, total areawide emissions may remain approximately the same as 1977 , but the concentration of traffic near the project could adversely affect businesses, residences, schools, or other possibly sensitive receptor sites.

The line source model used in the assessment is the model designated by the acronym CAI.INE2, a line-source model similar to the EPA's HIWAY model with an excellent record of model verification for a variety of roadway configurations. Input conditions include very light winds, 


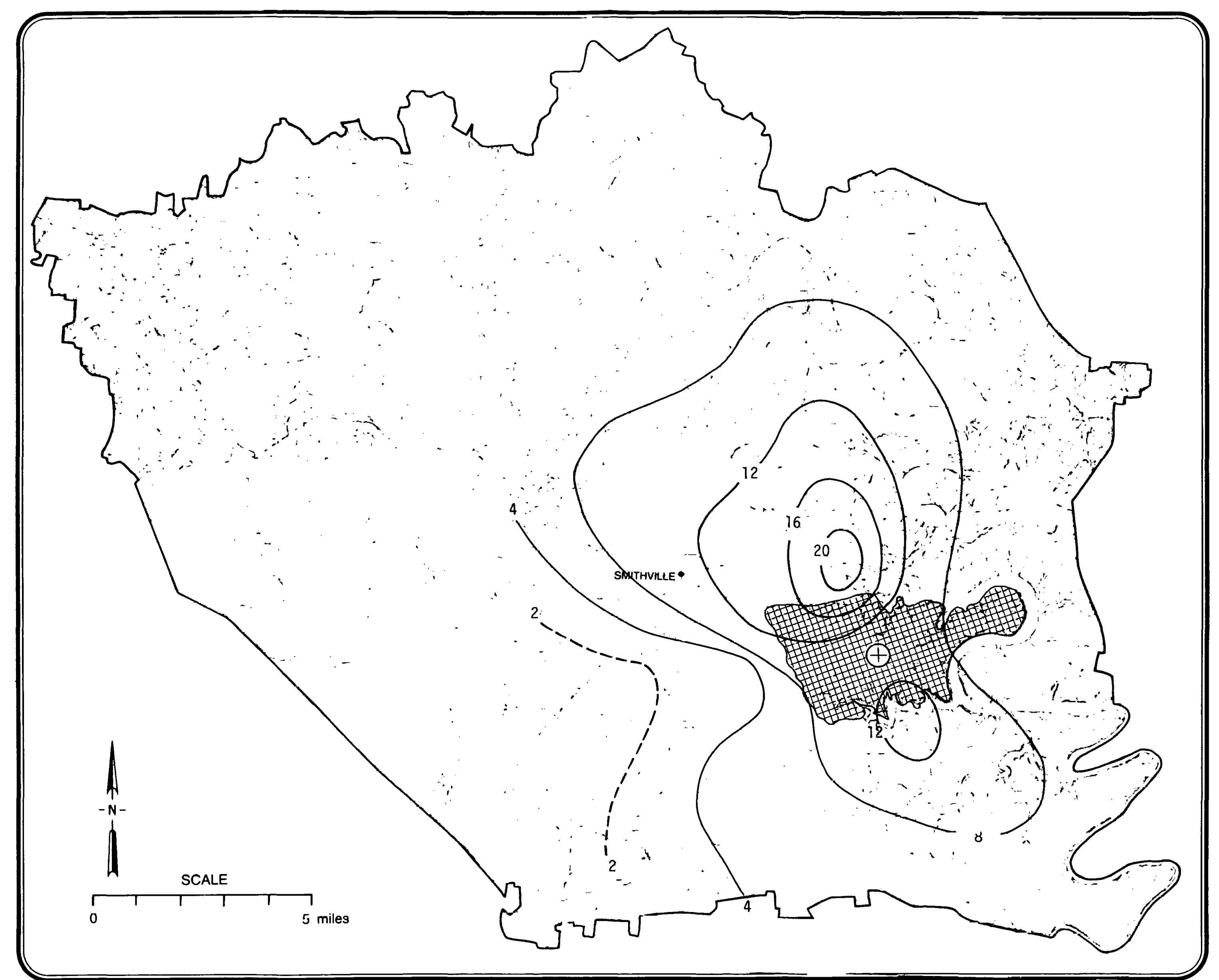

ANNUAL AVERAGE IMPACT OF SO2 FROM CHATTANOOGA SHALE OIL RECOVERY OPERATIONS $(\mu \mathrm{g} / \mathrm{m} 3)$

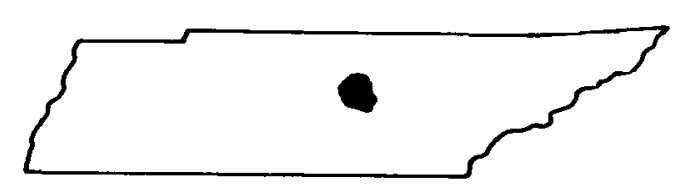

\section{KEY}

$\oplus$ Source (Refinery Stacks)

Prototype Project

FIGURE XII-7 
Pasquill "F" stability, and two-thirds of the construction labor force passing the same four-lane divided roadway section during 1 hour, with 95 percent of all vehicles either passenger vehicles or light-duty trucks (pickups) and vans.

The resulting CO pattern on either side of the roadway is shown in Figure XII-8. The winds parallel to the roadway maximize, the impact immediately adjacent to the roadway (parallel winds are assumed to meander $\pm 10^{\circ}$ to allow for diffusion away from the roadway centerline). Even with 3,000 cars per hour (a conservative overestimate), hourly maximum concentrations of CO would reach only $6.1 \mathrm{ppm}$, or less than 20 percent of the hourly CO standard. Since neither the traffic nor the restrictive meteorology will last for long, the 8-hour Co standard will not be threatened either. Despite the magnitude of the proposed resource development, the air pollution levels around the plant and roadways will not approach the same levels currently experienced in more urbanized or industrialized areas of Tennessee, Kentucky, or Alabama. 
400

\section{ROADWAY EMISSIONS IMPACT UNDER HYPOTHESIZED WORST-CASE CONDITIONS}

DISTANCE FROM ROADWAY (feet)

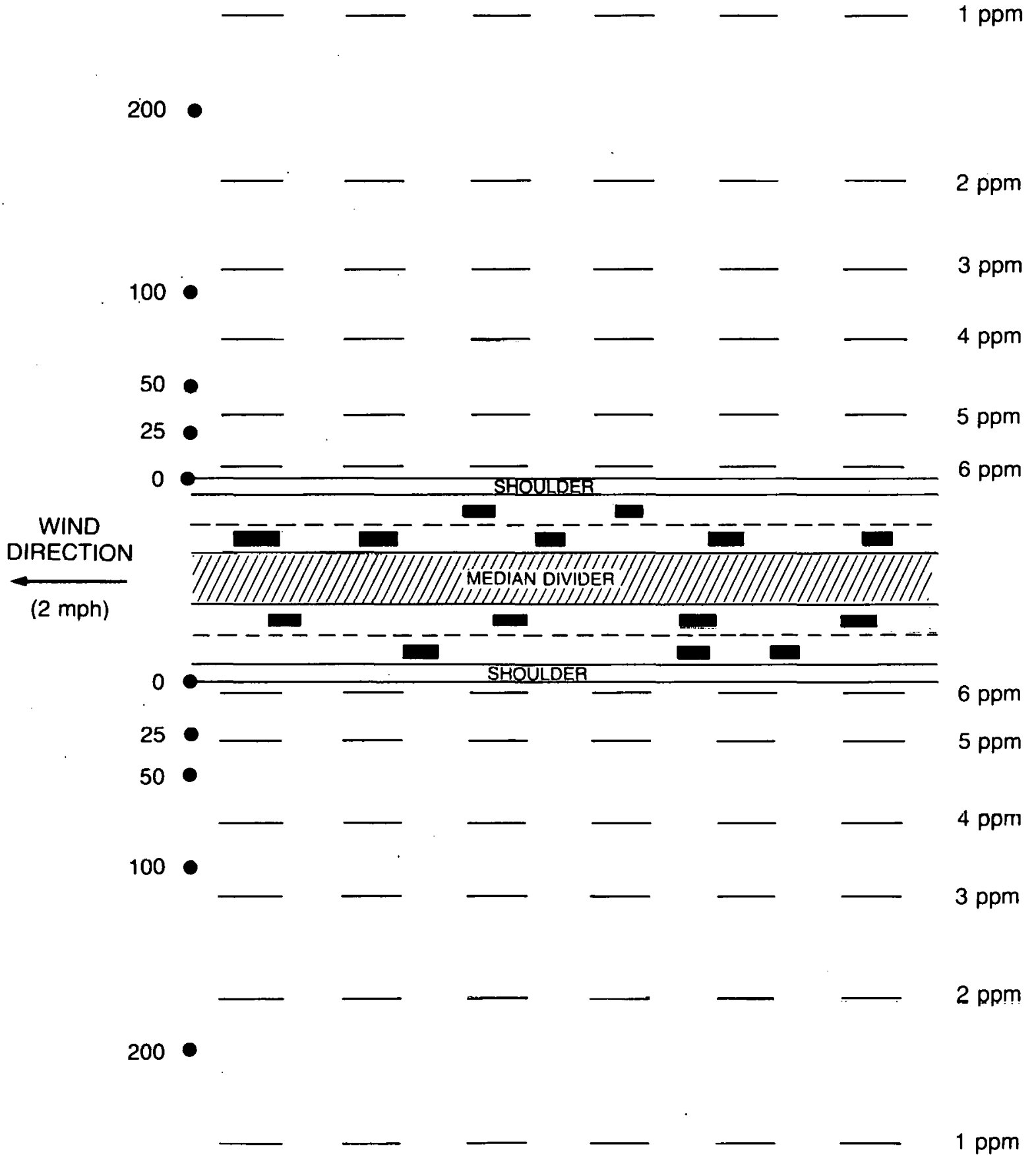

FIGURE XII-8 
SECTION XIII

CULTURAL RESOURCES

Considered in this section are the principal components of the sociocultural environment and what impacts these components may be expected to experience as a result of implementation of the project in question. Strong emphasis in this section is addressed to the local level, although a very general characterization of the regional study area is provided to establish context for broad extrapolation of local impact projections to the regional level.

\section{REGIONAL CHARACTERIZATION}

The four-state regional study area exhibits an over-all rural character, however, within this general character is a social and economic diversity between urban centers and rural areas that offers a picture of wide contrast.

The natural environment both supports and restricts land uses and the life-style of the population. The terrain, as described elsewhere, presents a variety ranging from low-lying agricultural areas to the mountains of Appalachia, with a strong influence exerted throughout much of the area by the Tennessee River and other water bodies. In general, the land is devoted to forest and agricultural uses except where voids have been created by urban centers (see Figure XIII-I). Despite the dominance of non-urban territory within the region, the most significant changes occurring therein are associated with the relatively small amount of land presently in, or changing to, urban use.

Intensity of land utilization in the region covers the entire spectrum of densities ranging from the highly concentrated urban centers of Nashville, Chattanooga, and Huntsville, to the rural territory of Appalachia. Every section of the region is faced with immediate and/or 


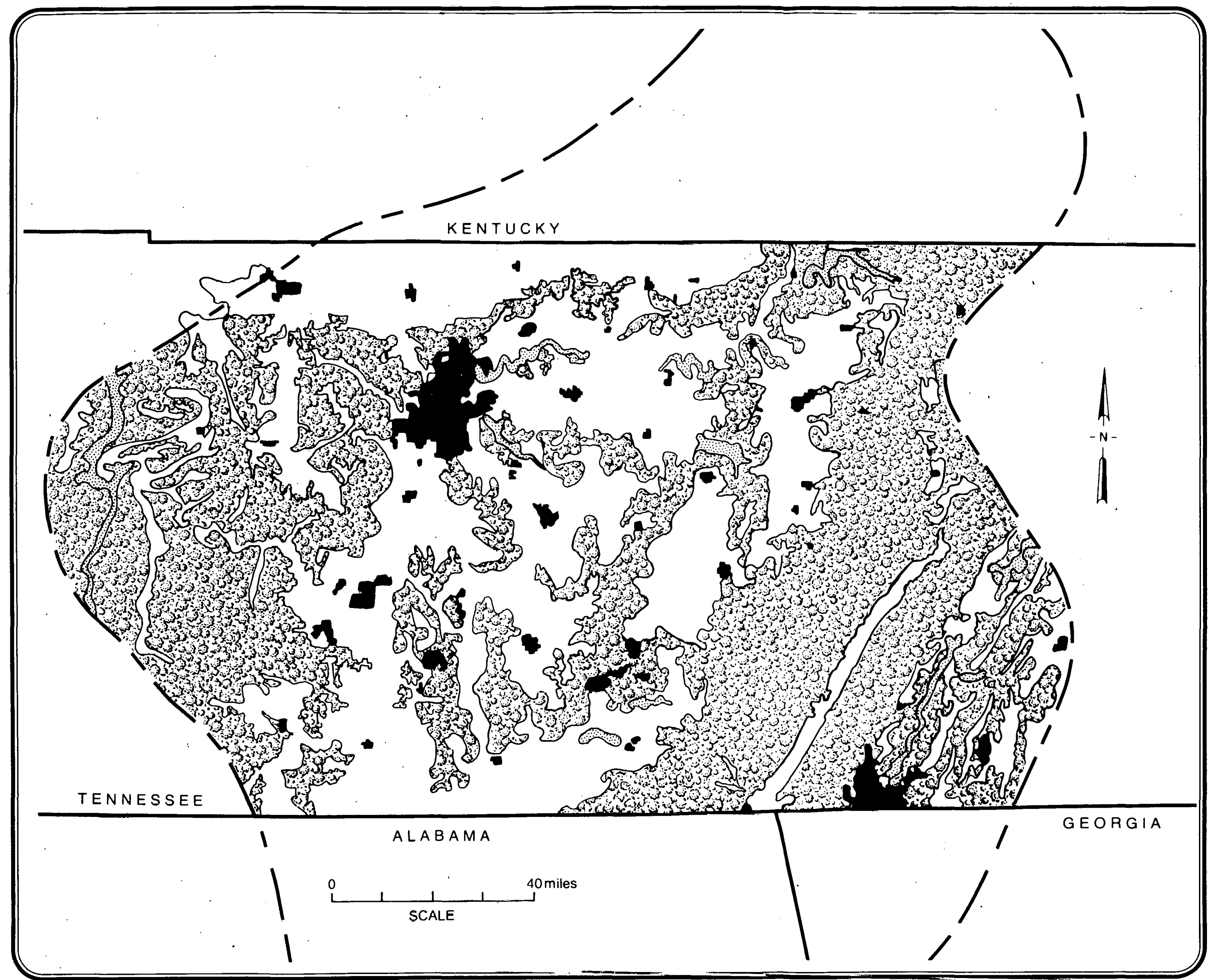

GENERALIZED LAND USE

PATTERN IN TENNESSEEE PORTION OF REGIONAL STUDY AREA

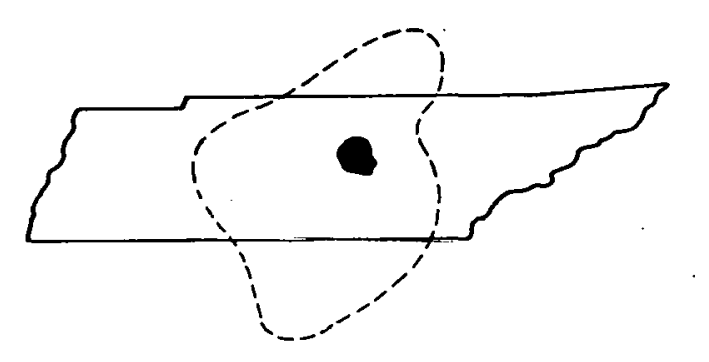

KEY

- - Study Area

U Urban

$\square$ Agricultural

Forest

Water

FIGURE XIII-1 
developing problems of physical and social ecology, viz., the imbalances and incompatibilies created by the distribution of people and economic activities across the land. In response to population increases (the magnitude of which has been steadily rising) and the greater per capita generation of wastes, additional demands are being placed upon regional lakes, rivers, streams, and refuse disposal sites, many of which are already utilized to capacity.

\section{POPULATION}

General trends among the regional population are: 1) population decline in rural areas -- the spatial distribution trends of the primary population for the 1978-1990 period will be a continued decline in the non-urban population, a net in-migration to various small urban portions of the region experiencing out-migration in the past, and tremendous growth of the urban metropolitan areas; 2) continued aging of the regional population with the rural areas exhibiting oldex median age than urban areas; 3) black population expected to increase but at a slower rate than the white population -- this should occur because of a reduction in the out-migration of the region's black residents, resulting in a stabilization of the minority population; 4) regional growth in which in-migration is a greater factor than natural increase -- heavy in-migration to urban areas has been responsible for their large population increases, and in-migration of population into the primary urban areas of the region is expected to continue, 5) significant decline in recent years in the natural rate of population increase following a drop in the birth rate in almost all counties -- as the population change declines (resulting from the ratio of number of births to number of deaths), the in-migration impact as a growth factor increases. For incorporated areas, annexation has been the primary determinant of population size. It has not been unusual for a city to loose population in its older areas yet experience sizable growth through the annexation of fringe areas. 


\section{EMPLOYMENT}

In recent years manufacturing has been increasing both as a source of employment and as a source of income. In general, the manufacturing sector is continuing to diversify and grow. Many new industries are locating outside of non-urban areas where low wages prevail and provide for predominently female employment. The dominance of low-paying industries is especially evident in the more remote areas of the region, whereas the higher paying industries are continuing to locate in urban areas:

Agriculture has declined as a source of employment while the total value of farm products sold has increased.its earnings. Farms are becoming larger with fewer full-time employees needed for production. It is expected that agriculture will continue to decline in acreage and as a source of employment in the region; nevertheless, it will likely remain a significant factor in the area!s economy.

Trade functions in the region have evolved in response to general economic development. Most retail firms are of the type which have smali labor requirements in addition to the proprietor. This situation is beginning to change however in the larger trade areas. Increasing population and incomes have provided the necessary economic base for larger stores and shopping centers in the urban areas.

The present composition of the service sector is undeveloped. Expansion in the industrial base of the region will provide an areal economy that is able to support a more extensive service industry.

The recreation industry is an expanding component of the regional economy. The region is blessed with scenic beauty, parks, resorts, lakes, rivers, and reservoirs. Further, many areas are endowed with the increasingly rare attribute of remoteness from the pressures of modern civilization. This is a quality of growing value among urbanized society, and therefore renders an area very attractive for recreational use. 
The following narrative describes the cultural environment of DeKalb County and surrounding area in terms of land use, population, housing, employment, income, and public facilities.

\section{LAND USE}

The land use of an area is greatly influenced by its topography, as well as soil drainage and climatic conditions. In DeKalb County, as described earlier, the topography is characterized by level to gently rolling hills for a radius of 3 to 5 miles around Smithville, beyond which the land changes to steep slopes and ridges in the eastern, northern, and western portions of the county. The topography is level-to-gently rolling in the area south of Smithville to the county's southern border.

Topographic limitations, in addition to the impoundment of the Caney Fork River and resultant formation of Center Hill Lake, have been among the greatest influences upon land use changes in DeKalb County. The creation of Center Hill Lake in effect changed the agricultural economy of the northeastern portion of the county to recreation and tourism, thus limiting remaining agriculture to the flat, southern portion of the county.

The most significant land uses in DeKalb County are presently forest, crop, pasture, and recreation-oriented uses. The county is striving to stimulate its economy while delicately balancing its rural character. To further this end, the 1960 General Plan calls for preserving large portions of the agricultural land, particularly in the south central area of the county, and along the stream valleys in western DeKalb County. The largest growing agriculture business in the county is nurseries, and the southern portion of DeKalb has recently become competitive with neighboring Warren County's vast nurseries.

A growing tourist industry around Center Hill Lake has stimulated the development of second homes, camp sites, and resort cabins. Current 
plans are to limit cabins and home development in this area because their septic tanks are causing pollution problems in Center Hill Lake. As a result of the tourist trade, commercial land uses are located along Highway 56 from Interstate 40 to Center Hill Lake. Upon completion of the Appalachian Arts Center (east of Hurricane Bridge on Highway 50) seven'million tourists are expected to visit DeKalb County annually. Commercial services and retail outlets are expected to occur as a spin-off to these attractions, especially in tourist-related businesses.

In addition to the Center Hill Lake area, much new residential development has occurred in and around the municipalities of DeKalb County, especially to the north of Smithville. Currently, the majority of the residential land is located in Smithville, with new individual homes also locating along several county roads in the central and southern portions of the county. Until 1971, only 10 percent of the homes of the county were serviced by waterlines, thus restricting much of the residential growth to the proximity of 'towns, but by 197585 percent of the county's homes had access to water lines. This has made it possible for the amount of land in residential uses to increase, spreading outward from Smithville along the county roads.

According to the DeKalb County Summary Plan it is advisable to limit the northerly expansion of Smithville because of the topographic depression caused by Fall Creek. The town cannot provide sewer service to these northern subdivisions without the use of costly sewage lift stations. Since the policy calls for a gravity flow system, development is encouraged to locate to the southwest, northwest, and southeast of Smithville where the land is relatively flat. In order to house by 1995 the additional 1,500 people projected for DeKalb County, it is estimated that another 447 acres of residential land will be needed.

Recent changes in the economy of DeKalb County have attracted an expanding commercial (trade and services) sector to Smithville, which acts as the county's urban center. Commercial development is concentrated in and adjacent to Smithville, with small neighborhood retail and services outlets serving the population of the three other county communities. 
By 1995, 20. additional acres of commercial land will be needed. Most of this land will be developed in the vicinity of Smithville, concentrated on Highway $70 \mathrm{~S}$ to the south of the present commercial business district.

Industrial development is being actively pursued in DeKalb County. In the past decade a large number of acres have been set aside for industrial use in expectation of increasing growth in this section of the economy. It is estimated that by 1995 an additional 31 acres will be needed, but there is still presently much room for growth adjacent to the Smithville Industrial Park.

According to Table XIII-1, 31 additional acres will be needed by 1995 for semi-public and public land use. The majority of this increase will take the form of community and neighborhood parks in the incorporated cities.

\section{SOCIAL PROFILE}

The following social profile of DeKalb County and surrounding area is presented in terms of population and housing.

\section{Population}

A population is attracted to, held, or repelled by a region because of its services, recreational and employment opportunities, and quality of life. In turn, the resulting demographics are the basis of any further economic growth and/or opportunities. Without a thorough knowledge of population characteristics, any resource allocation for the future needs and desires of a region's population cannot be made efficiently or in the best interest of all concerned.

The population and economy of a region are dependently interrelated, and opposing views exist on which is the primary attractor: the economy or the population. There is a point at which an added unit of labor does not necessarily increase production, resulting in a break in the economic cycle. This point of diminishing returns occurs when the economy can no 
TABLE XIII-1. EXISTING AND PROJECTED LAND USES IN DEKALB COUNTY (1975-1995)

\begin{tabular}{|c|c|c|c|c|}
\hline \multirow[b]{2}{*}{ Classification } & \multicolumn{2}{|c|}{ Existing (1975) } & \multicolumn{2}{|c|}{ Future (1995) } \\
\hline & Acres & $\begin{array}{l}\text { f Total } \\
\text { Land }\end{array}$ & Acres & $\begin{array}{c}\% \text { of Total } \\
\text { Land }\end{array}$ \\
\hline Residential & 3,693 & 1.82 & 4,140 & 2.04 \\
\hline Commercial & 162 & 0.08 & 182 & 0.09 \\
\hline Industrial & 94 & 0.04 & 125 & 0.06 \\
\hline Public and Semi-Public & 11,239 & 5.54 & 11,272 & 5.55 \\
\hline Transportation & 3,287 & 1.62 & 3,451 & 1.70 \\
\hline Water & 18,034 & 8.89 & 18,034 & 8.89 \\
\hline $\begin{array}{l}\text { Agriculture and } \\
\text { Fores.t }\end{array}$ & 166,435 & 82.01 & 165,740 & 81.67 \\
\hline Total Area, County & 202,944 & 100.00 & 202,944 & 100.00 \\
\hline
\end{tabular}


longer support any increase in the population. This is especially true of an extractive economy, which DeKalb County always has had. Resources have been substantially depleted, forcing the population to make one of three choices: starve, change the economic base, or reduce the population level.

The analysis and understanding of a population and the factors determining its size and distribution is essential to enable business, industry, and people to make the choices necessary to determine a desirable level for the economy. By reviewing population characteristics, it is possible to disclose linkages that reveal where a break in the symbiotic cycle of the economy and population may have originated.

\section{Growth Rate}

DeKalb County is part of the Upper Cumberland Development District, (UCDD) one of the most rural regions of Tennessee, consisting of 11,300 people dispersed throughout an area of 317 square miles. The largest urban center in the county is Smithville, with a population of 3,550 in 1977.

As in much of rural America, there have been significant population losses in the past 3.5 decades because of the economy. Table XIII-2 shows that for the first time in three decades, an increase in population was recorded in DeKalb County from 1960 to 1970. However, the population has not even approached the 1940 level of 14,588 . The population trend seems to be related to the slow conversion from a resource-oriented to an industrial economy. Only during the past 10 years has the local economy been diversified enough to offer employment opportunities to the increased population of the county.

Table XIII-3 shows that even between 1960 and 1970, while the population was stabilizing, DeKalb County continued to lose its young, productive. individuals. As shown, the greatest losses occurred between the ages 15 and 30 . This is indicative of the lack of employment for the young entering the labor market. 
TABLE XITII-2. TRENDS় IN DEKALB COUNTY POPỤLATION SIZE (1940-1976) [a]

\begin{tabular}{|c|c|c|c|c|c|c|c|}
\hline Year & Population & $\begin{array}{r}\text { Population } \\
\left(\mathrm{mi}^{2}\right)[\mathrm{b}]\end{array}$ & $\begin{array}{c}\% \\
\text { Change } \\
\end{array}$ & $\begin{array}{l}\text { Total } \\
\text { Change }\end{array}$ & $\begin{array}{c}\text { Compon } \\
\text { Natural } \\
\text { Increase }\end{array}$ & $\begin{array}{l}\frac{f \text { change }}{\text { Net }} \\
\text { Migration }\end{array}$ & $\begin{array}{c}\% \\
\text { Average Annual } \\
\text { Natural Increase }\end{array}$ \\
\hline 1940 & 14,588 & 52.4 & & & & & \\
\hline 1950 & 11,680 & 42.0 & -19.9 & $-2,908$ & 1,383 & $-4,291$ & 10.0 \\
\hline 1960 & 10,774 & 38.7 & -7.8 & -906 & 1,176 & $-2,082$ & 10.1 \\
\hline 1970 & 11,151 & 40.1 & 3.4 & 377 & 827 & -450 & 7.7 \\
\hline $1980[\mathrm{c}]$ & 11,400 & 41.0 & 2.2 & 249 & & & \\
\hline
\end{tabular}

[a] Source: Upper Cumberland Development District Office

[b] Exludes water, resulting in 278.3 total square miles of land.

[c] Projected. 
TABLE XIII-3. NET MIGRATION FOR DEKALB COUNTY, 1960-1970 [a]

\begin{tabular}{crr}
\hline $\begin{array}{c}\text { Age in } \\
1970\end{array}$ & $\begin{array}{c}\text { Net } \\
\text { Migration }\end{array}$ & $\begin{array}{c}\text { Net } \\
\text { Migration } \\
\text { Rates }\end{array}$ \\
\hline & & \\
Tota1 & -494 & -0.0434 \\
$0-4$ & 5 & 0.0056 \\
$5-9$ & -66 & -0.0614 \\
$10-14$ & -43 & -0.0430 \\
$15-19$ & -130 & -0.1311 \\
$20-24$ & -336 & -0.3233 \\
$25-29$ & -267 & -0.2948 \\
$30-34$ & -9 & -0.0138 \\
$35-39$ & -19 & -0.0330 \\
$40-44$ & 63 & 0.1111 \\
$45-49$ & 5 & 0.0073 \\
$50-54$ & 66 & 0.1066 \\
$55-59$ & 42 & 0.0728 \\
$60-64$ & 87 & 0.1684 \\
$65-69$ & 41 & 0.1005 \\
$70-74$ & 55 & 0.1680 \\
$75-79$ & 19 & 0.0680 \\
$80-84$ & -1 & -0.0058 \\
$85+$ & -6 & -0.0511 \\
\hline
\end{tabular}

[a] Source: State of Tennessee and University of Tennessee Center for Business and Economic Research [1972]. 
Partially responsible for the decline in the young sector of the population has been their pursual of education outside the county. The continued absence of adequate skilled employment opportunities in DeKalb County could discourage many of the more educated young from returning to live after finishing their education. This is especially worrisome because of the low median education and social attitudes towards education in the county. The effects of a poorly educated public are fewer local job opportunities and lower incomes than the state average. The trend since 1971 has been towards a slight return of this productive age group, as manufacturing jobs have entered the county.

There are two major forces that have contributed to the population changes of the past 40 years. They are net natural increase and net migration (Table XIII-2). Net out-migration has occurred since the 1940's when the Center Hill Dam replaced thousands of acres of farmland. The out-migration began to slow in the $1960^{\prime} \mathrm{s}$, and may possibly reverse itself by 1980 . The progress that DeKalb County has experienced in retaining its population has been due to two factors: 1) the diversification of job opportunities in the $1960^{\prime} \mathrm{s}$; 2) after the massive outmigration of the 1940's and 1950's, fewer people remain in the age group that tends to migrate from the county.

While the out-migration rate declined in the 1960 's and has stabilized in the 1970 's, the rate of natural increase has continually declined. Partially responsible is the out-migration of many women in the childbearing age gronp. In addition, the women in the county have followed national trends towards better contraception methods, better education, and changing attitudes towards smaller family size. Another factor that has had an effect upon the natural increase is the children/women ratio. Table XIII-4 shows that in the past 25 years, the ratio has decreased in actual numbers, and increased its annual percentage of decline. A possible explanation for this is the increasingly better job opportunities made available to women as small industries have entered the DeKalb County economy. This change has had a dual effect: increased household income and a lower county birthrate. 
TABLE XIII-4. CHILDREN/WOMEN RATIO IN DEKALB COUNTY, 1950-1970

\begin{tabular}{lccc}
\hline Year & Median Age & $\begin{array}{c}\text { Females } \\
15-44\end{array}$ & $\begin{array}{c}\text { Children/1000 Women } \\
\text { Ratio }\end{array}$ \\
\hline 1950 & 28.0 & 2,446 & 504.5 \\
1960 & 31.3 & 2,112 & 476.8 \\
1970 & 33.1 & 2,163 & 417.5 \\
\hline
\end{tabular}


One of the noticeable results of the extensive out-migration of young people and declining natural increase is that the median age of the county's population has risen during the 1960's and 1970's. Contributing to this trend has been an increase in in-migration of elderly and retiring people, often returning to DeKalb because of its low cost of living, unhurried atmosphere, scenic beauty, and recreational benefits. With increased life expectancy also contributing to the situation, the result is that the average age of the population is increasing faster than the state or national average. In 1970 the median age for the county was 33.1 , and 28.1 for the state. An absolute as well as percentage decline in the productive population below age 44 has been taking place. Simultaneously there have been significant increases in the population above 44 years of age (see Table XIII-5). Even though the national trend is for an aging population with a shrinking birthrate, DeKalb County's population is aging much faster than that of the State of Tennnessee or the nation.

An examination of population changes for DeKalb County between 1960 and 1970 demonstrates that the female population is increasing especially in the older age groups, while the male population is generally on the decline in all age groups. This may reflect the male population exodus to seek employment or further their education. An aging population implies a greater demand for certain facilities and services, because of the changing needs of a population with a different character.

The population per household in DeKalb County has decreased from 3.4 to 3.0 between 1960 and 1970. This drop in household size coincides with the movement of young married couples with children out of the county (see Table XIII-6). The number of households has increased from 3,208. in 1960 to 3,752 in 1970 .

The figures for population per household, percentage of the population that is female, and percentage of the population that are of natural parentage are about the same for DeKalb County as for Tennessee as a 
TABLE XIII-5. PERCENTAGE CHANGES IN AGE GROUPS STRUCTURE, 1960-1970 [a]

\begin{tabular}{|c|c|c|c|c|c|c|c|c|c|c|}
\hline & \multicolumn{2}{|c|}{$0-14$} & \multicolumn{2}{|c|}{$15-24$} & \multicolumn{2}{|c|}{$25-44$} & \multicolumn{2}{|c|}{$44-64$} & \multicolumn{2}{|c|}{$65+$} \\
\hline & 1960 & 1970 & 1960 & 1970 & 1960 & 19.70 & 1960 & 1970 & 1960 & 1970 \\
\hline DeKa lb & 23.4 & 25.8 & 14.7 & 14.4 & 24.0 & 22.7 & 20.9 & 24.0 & 12.0 & 13.1 \\
\hline Percent Change & \multicolumn{2}{|c|}{-2.6} & \multicolumn{2}{|c|}{-0.3} & \multicolumn{2}{|c|}{-1.3} & \multicolumn{2}{|c|}{+3.1} & \multicolumn{2}{|c|}{+1.1} \\
\hline Tennessee & 27.9 & 17.8 & 23.9 & 20.2 & 20.5 & 9.2 & 9.8 & & & \\
\hline Percent Change & & & & & & & & & & \\
\hline
\end{tabular}

[a] Source: 1960, 1970 U.S. Census of Population

层 
TABLE XIII-6. SUMMARY OF DEKALB COUNTY POPUUTATION CHARACTERISTTICS, 1970

\begin{tabular}{cccccccc}
\hline & Population & $\begin{array}{c}\text { Population per } \\
\text { Square Mile }\end{array}$ & $\begin{array}{c}\text { Number of } \\
\text { Families }\end{array}$ & $\begin{array}{c}\text { Population } \\
\text { Per Family }\end{array}$ & $\begin{array}{c}\% \\
\text { Female }\end{array}$ & $\begin{array}{c}\% \text { of Native } \\
\text { Parentage }\end{array}$ & $\begin{array}{c}\% \\
\text { White }\end{array}$ \\
\hline DeKalb & 11,151 & 35.4 & 3,246 & 3.4 & 59.9 & 99.9 & 97.9 \\
State & $3,923,726$ & 92.9 & $1,024,446$ & 30.9 & 18.8 \\
\hline
\end{tabular}


whole. However, a much higher percentage of the population is white in DeKalb County than in the entire state because of the historical development of the region. The terrain of DeKalb County is not suitable for cotton production thus slavery was not common in the area in the past. Moreover, the remoteness of the area and lack of job opportunities therein have discouraged in-migration of minority groups.

\section{Projected Population Changes}

The comparatively sparse settlement (population per square mile) of DeKalb County in relation to the rest of the state (less than $1 / 2$ as dense) confers upon it the rural character which is beginning to constitute on of its main assets. As people seek less-crowded living conditions than found in the major urban areas, the population of DeKalb County may be expected to grow. The rural character combined with growing employment and improved transportation will allow areas such as Smithville, Alexandria, and Dowelltown to attract those urban residents seeking an alternative type of living environment.

In contrast, the population within DeKalb County has become increasingly urban as a direct result of the change from an agricultural/extractive (resource-oriented) economy to a manufacturing economy. In fact, the rural population within the county has changed from 100 percent in 1950 and 1960 , to 73.6 percent in 1970 . The farm population has declined from 65.1 percent in 1950 to 29.8 percent in 1970. The growth of Smithville due to the influx of people from rural areas of the county and urban areas of the state more than offsets the decline in population in the remainder of the county. While the counties of the UCDD have been losing population, most towns in the district have increased in population. This trend, whereby counties lose population while towns gain, has peaked in DeKalb County, as evidenced by Table XIII-7.

Smithville serves as an employment and shopping center for the surrounding rural area, thus attracting many people looking for work. It will continue to attract much of the future population growth in DeKalb 
TÄBLE XIII-7. COMPONENTS OF POPULATION CHANGE, ACTUAL AND PROJECTED, IN DEKALB COUNTY AND INCORPORATED TOWNS (1960-1990) [a]

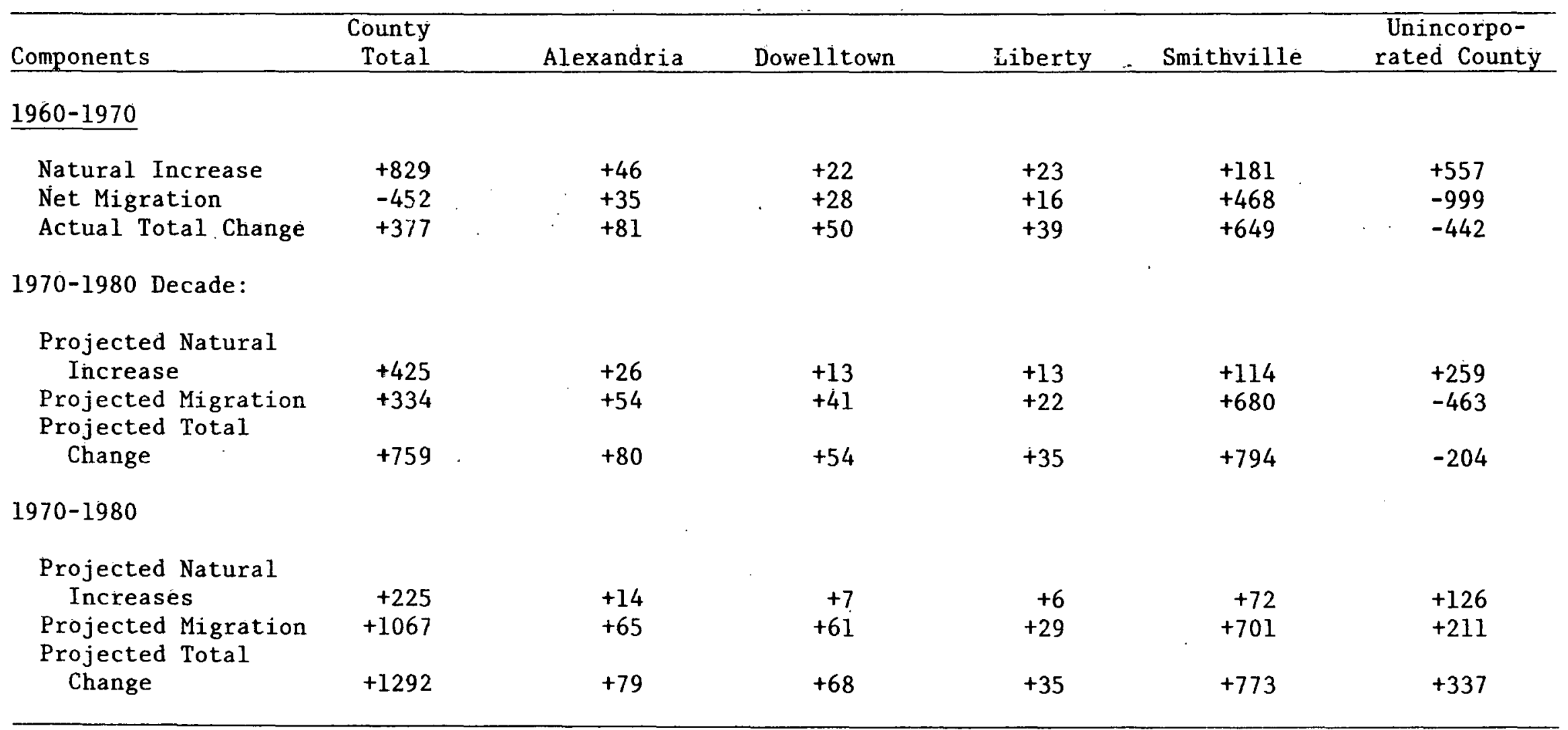

[a] Source: U.S. Bureau of the Census, 1960-1970; Upper Cumberland Development District [1977]. 
County as its manufacturing sector develops. Table XIII-8 shows that as the population of the county becomes increasingly urban, Smithville is predicted to experience continued population growth.

The 12-year forecast for DeKalb County is that the population decline has been reversed and that population is once again on the increase. The population increase is expected to be moderate, and will depend mostly upon the increases in urban areas such as Smithville. DeKalb is projected to continue to lose its young productive individuals, with the greatest losses occurring between the ages of 15 and 30 .

These projections are based upon past trends and the assumption that no large new manufacturing or extraction industries will be started, and that no major economic changes will occur, and that no unexpected natural disasters will take place. Of course, any projection is an estimate subject to unforeseen changes in technology, social attitudes, and many other potential factors such as the advent of a large uranium shale plant.

\section{Housing}

In the following discussion the present and projected housing stock in DeKalb County is related to potential population growth. If the population is to increase along with employment opportunities, there must be adequate housing in which to live. Currently, the UCDD embraces the highest percentage of households in need of adequate housing in all of Tennessee. Twenty-five perrent of the total households in the UCDD are living in less than adequate housing, versus 19.9 percent statewide. In DeKalb County 23.5 percent of the total households are living in less than adequate housing. Unless this situation is rectified, future population growth will not correspond to employment growth since new workers will have to find residence in other counties and commute into DeKalb for their jobs.

The 1970 U.S. Census of Housing and the Report on the Need for Housing in Tennessee [State of Tennessee $1977 \mathrm{~b}$ ] serve as the major sources for information presented in the following discussion. For purposes of this 
TABLE XIII-8. POPULATION TRENDS AND PROJECTIONS FOR DEKALB COUNTY AND SMITHVILLE [a]

\begin{tabular}{lccc}
\hline Year & DeKalb County & Smithville & $\%$ of County \\
\hline 1940 & 14,588 & 919 & 6.3 \\
1950 & 11,680 & 1,558 & 13.4 \\
1960 & 10,774 & 2,348 & 21.8 \\
1970 & 11,151 & 2,997 & 26.9 \\
1980 & 11,400 & 3,876 & 34.0 \\
1990 & 12,600 & 4,986 & 41.0 \\
\hline
\end{tabular}

[a] Source: 1940, 1950, 1960, 1970 U.S. Census of Population, Population Projections. 
discussion, "single-family" refers to type of structure, not type of occupancy. Single-family permanent residences are distinguished from mobile homes, although they both may be inhabited by only one family.

\section{Housing Type}

In 1970, there were 4,262 year-round housing units in DeKalb County. Of these, 92.1 percent were single-family, 4.7 percent multifamily, and 3.2 percent were mobile homes. From inspection of Table XIII-9, it is apparent that DeKalb County is dominated by single-family homes. However, in the 8 years between 1970 and 1978, the greatest percent change occurred in the addition of mobile homes, which increased 102 percent. In fact, the number of mobile homes has exceeded both state and development district proportions of mobile homes to total units.

Between 1970 and $1978,1,285$ units were added to the housing stock of DeKalb County. The composition of these units differs from the total stock existing in 1970 in two respects: 1) a decline in the percentage of single-family residences; 2) increases in the percentages of multifamily and mobile homes (see Table XIII-10).

These relatively new trends result from the severe shortage of adequate housing for the population of DeKalb County. As an alternative to the single-family home, which is beyond the budgetary reach of the average DeKalb household, increasing numbers of people are choosing mobile homes. While this trend is partly due to the convenience, lower cost, and practicality of a mobile home, it is not a very stable solution to the housing need in DeKalb County. The life-span of a mobile home is 15 years, thus they provide less than a permanent solution to the problem of inadequate housing in the county.

\section{Housing Condition}

"The measure for housing deficiencies", according to HUD and the Bureau of Census' 1970 Census of Housing, "consists of four variables. These are: 1) housing age compared with value; 2) lack of plumbing; 3) crowding; 
TABLE XIII-9. TOTAL HOUSING UNITS BY TYPE OF STRUCTURE (1970, 1978) [a]

\begin{tabular}{|c|c|c|c|c|c|c|c|c|c|c|}
\hline & \multirow{2}{*}{$197 \overline{0}^{\frac{\text { Tot }}{\circ}}$} & \multicolumn{2}{|c|}{ Year-Round Housing Units } & \multicolumn{2}{|c|}{ Single-Family } & \multicolumn{2}{|c|}{ Multifamily } & \multicolumn{3}{|c|}{ Mobile Homes } \\
\hline & & 1978 & $\%$ Change & 1970 & 1978 & 1970 & 1978 & 1970 & 1978 & $\%$ Change \\
\hline DeKalb & 4,262 & 5,547 & (30) & 3,925 & NA & 200 & NA & 137 & 301 & $(102)$ \\
\hline UCDD & 67,354 & 88,189 & (31) & 60,165 & NA & 3,604 & NA & 3,585 & 6,793 & (89) \\
\hline Tenn. & $1,294,808$ & $1,332,100$ & (3) & $1,034,394$ & NA & 212,100 & NA & 48,314 & 96,787 & $(100)$ \\
\hline
\end{tabular}

[a] Source: Tennessee Development District. Housing Starts. Final Report HC(1)-A-44; U.S. Bureau of the Census. Construction Reports: Housing Authorized by Building Permits \& Public Contracts, 1970-76. U.S. Bureau of the Census. 1970 General Housing Characteristics. 
TABLE XIII-10. PERCENT OF TOTAL PRIVATE HOUSING UNITS IN DEKALB COUNTY BY TYPE OF STKUCTURE $(1970,1978)[a]$

\begin{tabular}{rrrrrrrr}
\hline \multicolumn{2}{c}{$\begin{array}{c}\text { Total Year Round } \\
\text { Housing Units }\end{array}$} & \multicolumn{2}{c}{ Single-Family } & \multicolumn{2}{c}{ Multifamily } & \multicolumn{2}{c}{ Mobile Homes } \\
\hline 1970 & \multicolumn{1}{c}{1978} & 1970 & 1978 & 1970 & 1978 & 1970 & 1978 \\
4,262 & 5,547 & 92.1 & NA & 4.7 & NA & 3.2 & 5.4 \\
67,354 & 88,189 & 89.3 & NA & 5.4 & NA & 5.3 & 7.7 \\
$1,294,808$ & $1,332,100$ & 79.9 & NA & 16.4 & NA & 3.7 & 7.3 \\
\hline
\end{tabular}

[a] Source: Tennessee Development District. Housing Starts. Final Report HC(1)-A-44; U.S. Bureau of the Census. Construction Reports: Housing Authorized by Building Permits \& Public Contracts, 1970-76; U.S. Bureau of the Census. 1970 General Housing Characteristics. 
4) housing rental cost greater than 25 percent of income. Any one or combination of these four variables existing in a given unit indicates its inadequacy."

In 1970, there were 3,752 occupied housing units in DeKalb County of which 34 percent $(1,274)$ were classified as inadequate. By 1978 , both the number and percentage of inadequate housing had declined (21.4 percent: 1000 units). Compared with.DeKalb County and the state of Tennessee, the UCDD exhibited the greatest proportion of inadequate housing in $1970,36.4$ percent, decreasing to 23.2 percent in 1978. (Table XIII-11). While the situation in DeKalb County is better than that in the UCDD, it is significantly worse than average state conditions. Table XIII-11 shows that as the percentage of occupied units has increased, a.corresponding decrease in the percentage of inadequate units has occurred. This decrease stems from the expansion of water line service to include 80 percent of DeKalb County residences in 1978, compared to 30. percent in 1970 .

Even though the number of inadequate housing units has declined in the past 8 years, the unmet housing need in DeKalb County is still 1,097 units (see Table XIII-12). In order to alleviate this housing problem., new units must be added constantly to replace inadequate units, provide for population growth, and to maintain a sufficient vacancy level to provide housing choice.

According to Table.XIII-12, the number of housing units needed to fulfill these demands'has decreased; nevertheless"in order to provide adequate housing for everyone, approximately 302 units per year would have had. to be constructed during the 8-year period between 1970 and 1978. Since only an average of .165 units per year were constructed, this leaves an even larger total number of additional housing units needed by 1983. In addition, to the component of cumulative housing needed between 1980 and 1983 , there is the unmet need from 1970. Table XIII-13 portrays this compounding effect. 
TABLE XIII-11. ESTIMATED OCCUPIED HOUSING UNITS BY CONDITION [a]

\begin{tabular}{lrrrrrr}
\hline & \multicolumn{2}{c}{ Total } & Occupied Units & \multicolumn{2}{c}{ Adequate } & \multicolumn{2}{c}{ Inadequate } \\
\cline { 2 - 7 } & \multicolumn{1}{c}{1970} & 1978 & 1970 & 1978 & 1970 & 1978 \\
\hline \multirow{2}{*}{ DeKalb } & 3,752 & 4,663 & $66.0 \%$ & $78.6 \%$ & $34.0 \%$ & $21.4 \%$ \\
UCDD & 61,335 & 78,813 & $63.6 \%$ & $76.8 \%$ & $36.4 \%$ & $23.2 \%$ \\
Tennessee & & $1,459,620$ & $73.3 \%$ & $82.7 \%$ & $26.7 \%$ & $17.3 \%$ \\
\hline
\end{tabular}

[a] Source: U.S. Bureau of Census; U.S. Department of HUD Special Census Tabulation 
TABLE XIII-12. UNMET HOUSING NEEDS IN DEKALB COUNTY $(1970,1978)$

\begin{tabular}{|c|c|c|c|c|c|}
\hline & $\frac{\text { Unmet -Need }}{1970}$ & $\frac{\text { Cumulative Need }}{1978}$ & $\begin{array}{l}\text { Additions to } \\
\text { Housing Stock } \\
1970 \text { to } 1978\end{array}$ & $\frac{\text { Unmet Need }}{1978}$ & $\begin{array}{c}\% \text { of Households } \\
\text { in Need }\end{array}$ \\
\hline DeKalb & 1,176 & 2,416 & 1,319 & 1,097 & 23.5 \\
\hline UCDD & 22,021 & 41,750 & 22,150 & 19,600 & $25: 0$ \\
\hline
\end{tabular}


TABLE XIII-13. FUTURE AND CUMULATIVE HOUSING NEEDS, 1980 and 1983 [a]

\begin{tabular}{|c|c|c|c|c|c|c|c|c|}
\hline & $\begin{array}{c}\text { Unmet Need } \\
1970\end{array}$ & $\begin{array}{l}\frac{\text { Components }}{1970} \\
\text { to } 1980\end{array}$ & $\frac{\text { of Need }}{1970} \begin{array}{l}\text { to } 1983[\mathrm{~b}]\end{array}$ & Cumul & ive Need & $\begin{array}{l}\frac{\text { Total Ado }}{1970} \\
\text { to } 1978\end{array}$ & Lons & $\begin{array}{c}\text { Future Need } \\
1983\end{array}$ \\
\hline DeKalb & 1,176 & 1,428 & 1,690 & 2,604 & 2,866 & 1,319 & 1,285 & 1,547 \\
\hline UCDD & 22,021 & 23,587 & 28,271 & 45,608 & 50,292 & 22,150 & 23,458 & 28,142 \\
\hline
\end{tabular}

[a] Source: Tennessee Housing Development Agency [1977]

[b] See Breakdown.

BREAKDOWN OF 1970 to 1983 NEEI

局

Provide for Pop. Growth Replace Projected Losses Vacancy Adjustment

\begin{tabular}{lrrr}
\hline DeKalb & 1,408 & 254 & 28 \\
UCDD & $2 \Xi, 850$ & 3,931 & 490 \\
\hline
\end{tabular}


Predictions of future housing need indicate that 1,285 housing units must be constructed by 1980 (2,604 cumulative need minus 1,319 additions between 1970 and 1978), and another 262 by 1983. Thus to catch up, 309.7 units must be constructed during each of the next 5 years to meet these needs.

\section{Special Housing Needs}

As discussed earlier, the population structure of DeKalb County (and the UCDD) is characterized by a growing percentage of elderly persons. Because of their relatively low fixed incomes and increased need for special services such as health care, transportation, and shopping facilities, the elderly have special housing needs. Members of the population in this age group may have difficulty affording adequate housing and must either have the above services provided as part of their housing development or else their choice of housing location is limited to areas where such special services are available. In addition, special housing design is generally necessary to adequately accommodate elderly persons (see State of Tennessee [1977b]).

In DeKalb County, the sector of the population over 62 yeàrs of age has not only been increasing as a percent of total population, but according to Table XIII-14 it also has been aging relative to the state and development district. In $1970,16.4$ percent of the county population was considered elderly, compared with 15.0 percent for the UCDD, and 12.6 percent for the s.tate. By 1983, the elderly population of the state will have grown to 14.9 percent of total population, but DeKalb County's increases are expected to be significantly greater, rising to 22.1 percent in 1983. Since the percentage of persons 62 years of age and older is rising more rapidly than the overall increases in population, it is apparent that the addition of a growing number of housing units to the housing stock will be required to meet their needs.

Currently, there is not enough adequate housing to accommodate the existing population. By 1983 the situation should be slightly better. 
TABLE XIII-14. TRENDS IN ELDERLY (OVER 62 YEARS) COMPONENT OF POPULATION [a]

\begin{tabular}{lcccc}
\hline & \multicolumn{4}{c}{ Percent of } \\
\cline { 2 - 5 } & 1970 & 1978 & 1980 & 1983 \\
\hline DeKalb & 16.4 & 18.7 & 20.4 & 22.1 \\
UCDD & 15.0 & 16.6 & 17.6 & 18.6 \\
$\vdots$ & 12.6 & 13.8 & 14.2 & 14.9 \\
State & 12.6 & & \\
\hline
\end{tabular}

[a] Source: U.S. Department of Commerce [1976]; State of Tennessee [1974b]. 


\section{ECONOMIC PROFILE}

Historically, the economy of DeKalb County has always been tied to the land. Until the late $1800^{\prime} \mathrm{s}$, poor transportation isolated the county from the effects of the Industrial Revolution, and placed its economy 100 years behind that of the nation. As a result, the original frontier economy was based upon small subsistence farms, natural resource extraction, and timber. Economic colonialism, which began in the 1800 's by draining off most of the timber and mineral resources, effectively prevented the creation of an internal capital foundation and perpetuated the extractive base a half century longer than it might ordinarily have lasted.

By the 1940's the county's extractive economic base had reached its point of diminishing returns. Resources were substantially depleted, and several thousand acres of highly productive bottom land were confiscated in the course of the impoundment of Caney Fork River in 1948. Not only did this damage the agricultural economy, but it eliminated the only source of river transportation within the county. The taking of the bottom land forced the farmer to rely upon the less productive so called "flat woods country" of the county for growing his crops. This caused an initial loss of rural population as many moved to better land in neighboring counties or gave up farming for urban job opportunities elsewhere. It also resulted in an initial decrease in farm output as there was less productive land left. It has been just since 1960 that agricultural output has made a comeback primarily because of advancements in agricultural technology and new crops.

Since the early $1950^{\prime}$ 's the economy of DeKalb County has gradually begun changing from an agriculture/resource orientation to a more diverse economy based upon tourism, manufacturing, services, and farming. These emerging sectors are filling the gap left by the decline in agriculture activity. This is especially true for manufacturing.

Center-Hill Lake has acted as the final factor in breaking down the dominating agricultural economy, but it also offered opportunities for the birth of a thriving new recreation and tourism sector of the economy. 
Along with these changes the county has had to draw a line between attracting industrial development to offer employment opportunities, and retaining its rural character in order to promote a lucrative tourist industry. Until 7 years ago, DeKalb County was characterized by a conservative government that did not want any changes, even though the economy had reached its point of diminishing returns by that time. By 1971, the government changed, as did its views towards economic growth. Industrial development has been pursued actively to stem the out-migration of the county's population, and to stimulate new growth, higher income levels, and better employment opportunities. Thus far this new attitude has resulted in major changes in the economy and the creation of over 500 new industrial jobs by 1978 .

Currently, DeKalb County is raising its standard of living through the diversification of its economic base. Regional differences in life styles and living costs make comparison with national averages rather meaningless. A more realistic way of viewing the DeKalb economy is by comparing it to both the state and Upper Cumberland Development District. The county is still in the midst of emerging from its past, and consequently has just begun to close the gap in earnings and income. Even though it is still far behind, certain of its economic indicators are growing faster than for the state as a whole.

\section{Income}

Al1 the data concerning income levels in DeKalb County presented in the following discussion is in current dollars, meaning that inflation is not accounted for. Therefore, the best method of analyzing changing trends is to make comparisons with state and development district figures.

The best reflection of the standard of living and economic well-being of an area is its per capita and median family income: Table XIII-15 shows per capita personal income trends from 1960 to 1975 for DeKalb County, the UCDD, and the state of Tennessee. The per capita personal income for DeKalb County continues to exceed that of the UCDD, but remains far below the state level. However, the slow upward progression in the 
TABLE XIII-15. PER CAPITTA PERSONAL INCOME TRENDS [a]

\begin{tabular}{lcccccccc}
\hline Area & 1950 & $\begin{array}{l}\% \text { of } \\
\text { State }\end{array}$ & 1959 & $\begin{array}{l}\% \text { of } \\
\text { State }\end{array}$ & 1969 & $\begin{array}{l}\% \text { of } \\
\text { State }\end{array}$ & $\begin{array}{l}\text { 1975 } \\
\text { State }\end{array}$ \\
\hline DeKalb & $\$ 549$ & 55.2 & $\$ 1,013$ & 66.1 & $\$ 2,210$ & 75.5 & $\$ 4,083$ & 83.0 \\
UCDD & 551 & 55.4 & 961 & 62.7 & 2,091 & 71.4 & 3,726 & 75.9 \\
Tennessee & 994 & 100.0 & 1,532 & 100.0 & 2,926 & 100.0 & 4,909 & 100.0 \\
\hline
\end{tabular}

[a] Source: U.S. Department of Commerce, Bureau of Economic Analysis. 
DeKalb County per capita income level is expected to place it at 90 percent of the state level by 1980 because it is growing at a faster rate than is that of the state as a whole (see Table XIII-15).

Per capita personal income for the county increased 84 percent between 1950-1959, and 118 percent between 1959-1969. By 1975; the rate of increase had returned to 84 percent. This trend occurred at local and regional levels, as a result of the national prosperity experienced in the 1960's (see Table XIII-16).

Median family income is another measure of the economic picture in DeKalb County. It has grown at a faster rate than that of the state or development district for the past two decades (see Table XIII-17), while still remaining far below the state level. In 1959, the county's median family income was only 58.5 percent that of the state, with the UCDD at 60.2 percent of the state. But; by 1976 the economic picture had reversed i.tself such that DeKalb County median family income was 90.1 percent that of the state, and far ahead of the development district.

The 250 percent increase between 1959 and 1969 and continued increases in the 1970's are due mostly to the growth of small-scale manufacturing and service jobs in the county, and the resultant employment opportunities for working wives. As these opportunities have increased, so have the number of households with two incomes. This has had the effect of markedly raising family income, and increasing per capita personal income by a smaller amount. However, while median family income is only 10 perrent. 1ess than that of the state, per capita personal income is 17 percent less than the state figure.

The percentage distribution of households in a given income group is another indication of income levels in the county. Table XIII-18 indicates that in 1971 the percentage of DeKalb County households in the lower income groups was greater than the state percentage. In the 6-year period following, DeKalb County experienced a dramatic change in income distribution, resulting in a much higher purchasing power gained by local residents (the measure of income in Table XIII-18 is cash income). 
TABLE XIII-16. PERCENTAGE INCREASE IN PER CAPITA PERSONAL INCOME

\begin{tabular}{lrcc}
\hline Area & $1950-59$ & $1959-69$ & $1969-75$ \\
\hline DeKalb & 184 & 218 & 185 \\
UCDD & 174 & 217 & 178 \\
Tennessee & 154 & 191 & 108 \\
\hline
\end{tabular}


TABLE XIII-17. MEDIAN FAMILY INCOME [a]

\begin{tabular}{|c|c|c|c|c|c|c|c|c|}
\hline Area & 1959 & $\begin{array}{c}\% \\
\text { Change }\end{array}$ & 1969 & $\begin{array}{c}\% \\
\text { Change }\end{array}$ & 1976 & $\begin{array}{c}1959 \\
\% \text { of } \\
\text { State } \\
\text { Median }\end{array}$ & $\begin{array}{c}1969 \\
\% \text { of } \\
\text { State } \\
\text { Median }\end{array}$ & $\begin{array}{l}1976 \\
\% \text { of } \\
\text { State } \\
\text { Median } \\
\end{array}$ \\
\hline DeKalb & 2,309 & 250 & 5,782 & 180 & 10,414 & 58.5 & 77.6 & 90.1 \\
\hline UCDD & 2,377 & 227 & 5,384 & 162 & 8,724 & 60.2 & 76.1 & .75 .5 \\
\hline Tennessee & 3,949 & 189 & 7,447 & 155 & 11,561 & 100.0 & 100.0 & 100.0 \\
\hline
\end{tabular}

[a] Source: 1970 U.S. Census of Population [Since the data in this Table is taken from a different source than per capita personal income, (Table XIII-15) the figures are slightly lower than comparable figures based upon Bureau of Economic Analysis estimates.] 
TABLE XIII-18. EFFECTIVE BUYING INCOME, 1971 and 1976

\begin{tabular}{|c|c|c|c|c|c|c|c|c|}
\hline \multirow{3}{*}{ Area } & \multicolumn{8}{|c|}{ Distribution of Households by Income Groups } \\
\hline & & & $\$ 8$, & 999 & $\$ 10$, & 4,999 & & \\
\hline & 1971 & 1976 & 1971 & 1976 & 1971 & 1976 & 1971 & 1976 \\
\hline DeKalb & 75.1 & 38.7 & 8.6 & 9.4 & 10.8 & 19.9 & 5.5 & 32.0 \\
\hline UCDD & 77.6 & 46.2 & 8.5 & 10.5 & 9.1 & 20.2 & 4.8 & 23.1 \\
\hline Tennessee & 60.3 & 34.9 & 12.1 & 8.6 & 17.1 & 20.3 & 10.5 & 36.2 \\
\hline
\end{tabular}


During this period, there was a 36.4 percent decrease in households in the lowest income groups, while all other groups gained considerably. In fact, only 21.6 percent of all families (or 19.3 percent of the total county population) were below the poverty level in 1970. The higher household income in 1976 enabled the population to retain a larger portion of their income after paying for necessities, and to spend it in other sectors of the economy. The greater the amount of money in circulation; the greater the impact upon the local economy because of the economic multiplier.

By analyzing the sources of personal income, it is possible to identify the sources which bear the greatest responsibility for recent income growth in DeKalb County. From examination of Table XIII-19, it can be concluded that, since 1959, farm income has declined significantly in the county producing a resultant decline in its importance as a factor in the economy. In 1959, farm income (which was already on the decline) amounted to 27.5 percent of total personal income $(\$ 2,927,000)$. As more and more farmers sold their land to larger farms due to the decline in the economic viability of agriculture, the farm percentage of personal income decreased further to 10.9 percent $(\$ 2,270,000)$ in 1969 , and 6.6 percent $(\$ 2,990,000)$ in 1975 . Unless significant changes occur in farm commodity prices, thereby reweighting the factors of production, the agricultural sector will probably never regain its original importance in DeKalb County, even though it can be expected to remain important.

of the major sources of personal income, wages and salaries have undergone the most marked changes in the past two decades. This category has experienced a 524 percent increase from 40.1 percent of total personal income $(\$ 4,269,000)$ in 1959 to 49.6 percent $(\$ 22,385,000)$ in 1975 . Thus wages and salaries have become the largest and most important new source of personal income in the county. Much of the increase in wage/salary income can be attributed to the growth of the manufacturing and service sectors in the county. As the economy diversifies and becomes more urban, employment opportunities in manufacturing and the service trades are expected to expand. These changes can be expected to result in personal income becoming more firmly based upon wages and salaries, since employment will be more centralized. 
TABLE XIII-19. PERSONAL INCOME. BY MAJOR SOURCES IN DEKALB COUNTY

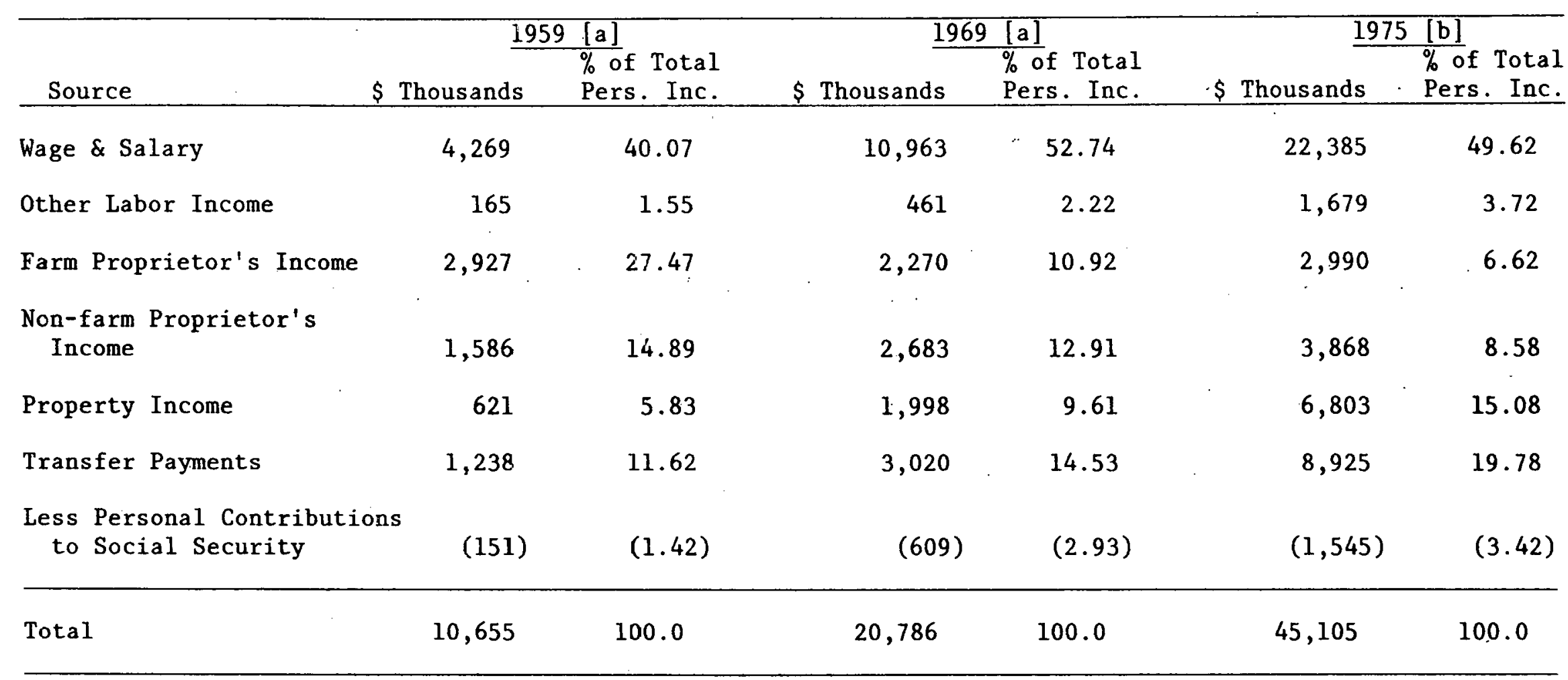

[a] Source: Center for Business Research, University of Tennessee. Personal Income Estimates, Tennessee, the Southeast and the Nation, 1929 to 1970. 1970.

[b] U.S. Department of Commerce, Bureau of Economic Analysis, Regional Economics Information System. 
DeKalb County's aging population structure has influenced the 1,023 percent increase in personal contributions to social security, which is the largest percentage increase of all sources, from 1.42 percent of total personal income $(\$ 151,000)$ in 1959 to 3.4 percent $(\$ 1,545,000)$ in 1975. The aging structure has also affected the 721 percent increase in government transfer payments from 11.6 percent of total personal income $(\$ 1,238,000)$ in 1959 to 19.8 percent $(\$ 8,925,000)$ in 1975. These increases are due to the reliance of the elderly population upon social security and welfare payments as their major source of income. The percentage of total personal income represented by social security and government transfers can be expected to parallel increases in the elderly population.

Employment:

The emergence of wages and salaries as the most important source of personal income in 'DeKalb County coincides with the shift in employment in recent times from extractive and agricultural to the manufacturing. and service 'sector'ś. During'the past 20 years, economic trends have : moved manufacturing to a position of superiority, with continued expansion in this sector receiving a boost from the Smithville-DeKalb County Industrial Development Committee, which is actively recruiting prospective industries. $\therefore$

DeKalb 'County's 'growing manufacturing sector -is attracted by the 'rural: amenities, recreational resources, low wages, and labor supply. Many of the new job opportunities, however, favor female employment, thus somewhat excluding men from the benefits of the growing manufacturing sector... Seventy" to eighty percent of all industrial jobs in DeKalb County-now? hire women; thus forcing many men to commute out of the county for work, or to 'remain unemployed.

Manufacturing employment in the county has: increased dramatically since 1950 when there were "on $1 y$ y 412 such jobs; constituting 11 percent of total employment. Table XIII-20 shows manufacturing employment increasing 426 percent between 1950 and 1970, to 1756 jobs. This growth increased 
manufacturing from 10.5 percent of total employment in 1950 , to 37.6 percent in 1970. Table XIII-21 shows that manufacturing employment has experienced steady gains since 1950. It can also be seen that manufacturing employment comprises a larger portion of total employment in DeKalb County than it does for the state of Tennessee, while tagging slightly behind the UCDD. Employment in this sector is expected to reduce the unemployment caused by agriculture reductions. Along with the national trend towards fewer and larger farms, agricultural employment will continue to decline, but at a much slower rate. Many of those previously employed in agriculture are turning to the manufacturing sector.

Increasing numbers of small farmers have begun to take part-time jobs in other sectors of the economy. Only 10 to 15 percent of the farmers depend solely upon their farm income; the remainder work part-time. The importance of the agricultural sector has not declined substantially in spite of the employment reductions, because new technology and new fertilizers have enabled agriculture earnings and production to increase with fewer workers. Nevertheless, the continuing political influence of farmers in DeKalb County is reflected by their representation in the county court: 7 of the 14 members.

Table XIII 21 shows that agricultural employment in DeKalb County has decreased from the 1950 level of 58.10 percent of total employment $(2,288)$ to only 12.84 percent $(586)$ in 1.970 . The declining trend in agricultural employment began in the late 1940 !s when Center Hill Lake eliminated 12,000 acres of prime farm land. Total agricultural earnings in 1960 were approximately $\$ 3,800,000$, increasing to approximately. $\$ 10,400,000$ in 1977 (see Table XIII-22 for a breakdown of these earnings). In fact, present earnings from agricultural products are even greater than their 1934 level when there were 27,000 farms in DeKalb County. This is because the new crops are developed for productive rather than consumptive use. At the same time that agricultural earnings have increased from 1960 to 1977, the number of farms has decreased by 150, from 1800 to 1650 . Many of these 1650 farms are subsistence. 
TABLE XIII-20. EMPLOYMENT BY MAJOR GROUP [a]

\begin{tabular}{|c|c|c|c|c|c|c|}
\hline Sector & $\begin{array}{c}1950 \\
\text { Total } \\
\end{array}$ & $\begin{array}{l}\text { Percent } \\
\text { of Total } \\
\text { Employment }\end{array}$ & Tota 1 & $\begin{array}{l}60 \\
\text { Percent } \\
\text { of Total } \\
\text { Employment }\end{array}$ & Total & $\begin{array}{l}70 \\
\text { Percent } \\
\text { of Total } \\
\text { Employment }\end{array}$ \\
\hline Manufacturing & 412 & 10.50 & 1,246 & 31.04 & 1,756 & 37.58 \\
\hline $\begin{array}{l}\text { Agriculture, } \\
\text { Forestry, and } \\
\text { Fisheries }\end{array}$ & 2,288 & 58.10 & 1,143 & 28.49 & 600 & 12.84 \\
\hline Construction & 321 & 8.20 & 348 & 8.67 & 549 & 11.74 \\
\hline Mining & 7 & 0.20 & 4 & 0.11 & 0 & -- \\
\hline $\begin{array}{l}\text { Wholesale and } \\
\text { Retail Trade }\end{array}$ & 324 & 8.20 & 482 & 7.44 & 565 & 7.97 \\
\hline Other Services [b] & 504 & 12.70 & 707 & 22.21 & 1,048 & 29.85 \\
\hline Not Reported & 84 & 2.10 & 82 & 2.04 & 0 & -- \\
\hline TOTAL & 3,940 & 100.0 & 4,012 & 100.0 & 4,518 & 100.0 \\
\hline
\end{tabular}

[a] Source: 1950, 1960, 1970 U.S. Census of Population; Upper Cumberland Development District [1973].

[b] Includes the following services: transportation, communication, and utility services; financial, insurance, and real estate services; repair and personal services; entertainment and recreation services; health, education, and welfare services; public administrative services; religious and nonprofit membership organizations; other professional and related services; and private household workers. 
TABLE XIII-21. EMPLOYMENT BY MAJOR GROUP AS A PERCENTAGE OF TOTAL EMPLOYMENT

\begin{tabular}{|c|c|c|c|c|c|c|c|c|c|c|c|c|}
\hline & \multicolumn{3}{|c|}{ Manufacturing } & \multicolumn{3}{|c|}{$\begin{array}{l}\text { Agriculture, } \\
\text { Fisheries, Forestry }\end{array}$} & \multicolumn{3}{|c|}{ Construction } & \multicolumn{3}{|c|}{ Mining } \\
\hline & 1950 & 1960 & 1970 & 1950 & 1960 & 1970 & 1950 & 1960 & 1970 & 1950 & 1960 & 1970 \\
\hline DeKalb & 10.50 & 31.04 & 37.58 & 58.10 & 28.49 & 12.84 & 8.20 & 8.67 & 11.74 & 0.20 & 0.11 & -- \\
\hline UCDD & & 28.59 & 38.22 & & 24.98 & 10.30 & & 7.16 & 8.36 & & 1.64 & 0.71 \\
\hline Tennessee & & 26.01 & 30.64 & & 10.80 & 4.25 & & 6.74 & 6.91 & & 0.73 & 0.48 \\
\hline
\end{tabular}

\begin{tabular}{|c|c|c|c|c|c|c|c|c|c|}
\hline & \multicolumn{3}{|c|}{$\begin{array}{l}\text { Wholesale/ } \\
\text { Retail Trade }\end{array}$} & \multicolumn{3}{|c|}{ Other Services } & \multicolumn{3}{|c|}{ Not Reported } \\
\hline & 1950 & 1960 & 1970 & 1950 & 1960 & 1970 & 1950 & 1960 & 1970 \\
\hline DeKalb & 8.20 & 7.44 & 7.97 & 12.70 & 22.21 & 29.85 & 2.10 & 2.04 & -- \\
\hline UCDD & & 9.32 & 10.14 & & 25.65 & 32.27 & & 2.70 & -- \\
\hline Tennessee & & 12.93 & 3.28 & & 39.43 & 54.43 & & 3.30 & -- \\
\hline
\end{tabular}


TABLE XIII-22. BREAKDOWN OF AGRICULTURAL EARNINGS IN DEKALB COUNTY, 1960 and 1970 [a]

\begin{tabular}{lcccc}
\hline & Field Crops & $\begin{array}{c}\text { Livestock and } \\
\text { Livestock Products }\end{array}$ & Nurseries & Total \\
\hline 1960 & $\$ 1,636,000$ & $\$ 1,802,000$ & $\$ 365,000$ & $\$ 3,803,000$ \\
1970 & $3,400,000$ & $3,000,000$ & $4,000,000$ & $10,400,000$ \\
\hline
\end{tabular}

[a] U.S. Department of Agriculture, DeKalb County Agricultural Extension Service. (personal communication). 
The average size of a farm in DeKalb County is 109 acres. Even though the land is not as fertile as the bottomland flooded by Center Hill Lake, new farming techniques and fertilizers have enabled many of these farms to become quite profitable. For example, in 1960, wheat production was 43 bushels produced per acre compared with 70 bushels per acre in 1977. (In 1934, 17.5 bushels of corn were produced per acre versus 75-90 in 1977). Table XIII-23 shows that during the past 17 years the nature of DeKalb County agricultural products has changed quite significantly. As the corn, tobacco, and wheat crops have declined, new products such as soybeans and nurseries (ornamentals and fruit trees) have increased substantially.

Various service sectors are gaining steadily as a major factor in the overall development of the county. An expansion of the industrial base can be expected to provide the economic stimulus to support a more extensive service industry. This is illustrated by the parallel of increases in this sector with those of the manufacturing sector. In 1950, 12.7 percent of total employment (504 jobs) was in services, increasing to 29.9 percent in 1970 ( 1,048 jobs). This trend follows that experienced by both the UCDD and Tennessee as a whole during the same period. Another indicator of expansion in the service sector is the 166 percent increase in its earnings occurring between 1965 and 1977 (see Table XIII-24).

The recent growth of the service sector is due partially to its previous under-developed status in the county. Therefore, after the sector has reached saturation level for local needs, the proximity of Nashville will likely act as a disincentive for its further development. Thus, services are expected to reach a level sufficient for local and tourist needs and then stabilize as the increase in manufacturing employment slows.

The natural scenic beauty of the lakes, forests, hills, and rural landscape in DeKalb County has always rendered it an attractive retreat from urban life. In 1948, the creation of Center Hill Lake greatly enhanced the recreation and tourist industry in DeKalb County. The 
TABLE XIII-23. DEKALB COUNTY AGRICULTURAL PRODUCTION, 1960 and 1970 [a]

\begin{tabular}{cccccccc}
\hline & $\begin{array}{c}\text { Corn } \\
\text { (acres) }\end{array}$ & $\begin{array}{c}\text { Tobacco } \\
\text { (acres) }\end{array}$ & $\begin{array}{c}\text { Wheat } \\
\text { (acres) }\end{array}$ & $\begin{array}{c}\text { Soybeans } \\
\text { (acres) }\end{array}$ & $\begin{array}{c}\text { Nurseries } \\
\text { (income) }\end{array}$ & $\begin{array}{c}\text { Cattle } \\
\text { (income) }\end{array}$ & $\begin{array}{c}\text { Hogs } \\
\text { (income) }\end{array}$ \\
\hline 1960 & 12,945 & 928 & N/A & $-0-$ & $\$ 365,000$ & N/A & N/A \\
1970 & 8,400 & 715 & 600 & 4,000 & $4,000,000$ & $\$ 26,000$ & $\$ 6,000$ \\
\hline
\end{tabular}

[a] U.S. Department of Agriculture, DeKalb County Agriculture, DeKalb County Agricultural Extension Service (personal communication). 
TABLE XIII-24. CHANGE IN DEKALB COUNTY EARNINGS BY BROAD INDUSTRIAL SECTOR, 1965 to 1970 [a]

\begin{tabular}{lccccccc}
\hline Farm & Non-Farm & $\begin{array}{c}\text { Private } \\
\text { Non-Farm }\end{array}$ & All Gov't & Manufacturing & $\begin{array}{c}\text { Transportation, } \\
\text { Communications } \\
\text { \& Utilities }\end{array}$ & $\begin{array}{c}\text { Wholesale/ } \\
\text { Retail Trade }\end{array}$ Services \\
\hline $7 \%$ & $\cdot 29 \%$ & $27 \%$ & $40 \%$ & $12 \%$ & $96 \%$ & $12 \%$ & $66 \%$ \\
\hline
\end{tabular}

[a] Source: OBE Earnings and Personal Income Data 
lake, situated in the rolling hills of northern DeKalb County, provides outstanding opportunities for recreational uses such as boating, swimming, fishing, camping, and picnicking. Center Hill Lake differs from many nearby lakes in that the Corps of Engineers' policy is to retain the rustic character of the area by prohibiting development along the shores, except for water-related facilities and picnicking areas. This policy has resulted in the predominantly day-use character of the area.

Eighty percent of the people using Center Hill Lake are day visitors, and 90 percent of these people originate within a 100 -mile radius; thus characterizing the area as within range for frequent use by visitors from Murfreesboro, McMinnville, Nashville, and Chattanooga. Due to the proximity within which the majority of DeKalb tourists originate, there has been little tourist-related development such as hotels. Yet, due to the growing number of tourists (see Table XIII-25); employment levels in related services and trades have experienced some increases. In 1958 there were 108 active proprietors and paid workers in major business groups serving travelers. By 1975, this figure had increased 251 percent, to 271. Another indicator of the growing importance of recreation and tourism is total tourist expenditures, which have increased from $\$ 472,000$ in 1958 to $\$ 4,477,589$ in 1975. Most of these expenditures were made in Smithville, since little development is located in the lake area where the Corps of Engineers owns 18,000 acres of adjacent land.

Adding to the attraction of Center Hill Lake is the adjacent 60,000-acre Edgar Evins State Park which offers a variety of water, camping, and other recreational facilities. Currently under construction is the Joe L. Evins Appalachian Arts Center which is expected to attract an additional 6 million tourists annually from 13 states. Besides expanding the market area of the DeKalb County tourist industry, the Arts Center is expected to attract a growing number of young, creative, intellectual types of families from throughout the eastern U.S., to take advantage of the art studios, music, and other cultural events offered by the Center. This trend has already begun, as many of these families have moved into the Smith Fork Valley in the southwest portion of DeKalb County. Most of these people attracted hy the Arts Center, recreation benefits, and 
TABLE XIII-25. PUBLIC VISITATIONS TO CENTER HILL LAKE 1971 to 1975 [a]

\begin{tabular}{ll}
\hline Year & Visitations \\
\hline 1971 & $3,170,400$ \\
1972 & $3,783,500$ \\
1973 & $3,556,200$ \\
1974 & $3,364,900$ \\
1975 & $3,425,300$ \\
1976 & $3,752,600$ \\
1977 & $4,200,000$ \\
\hline
\end{tabular}

[a] Source: U.S. Army Corps of Engineers [1977] 
scenic beauty are from eastern urban areas and are concerned with preserving the present quality of life.

Tourism in DeKalb County is a sleeping industry. Until recently, very little has been done to promote tourist visitation from outside Tennessee. Public Law 8972 states that the county must split the costs of any expansion of the park's and lake's recreational facilities. The Corps would readily expand camping and boating facilities, but the county would have to pay for maintenance, which they have not been willing to do. With the opening of the Appalachian Art Center, the county plans finally to tap the tremendous potential of the tourist and recreational industry. As this sector grows, it will enable many service and retail businesses to employ more people than would be possible if they served only the permanent population of DeKalb County.

Industries such as tourism or certain types of manufacturing that are "export" oriented, are especially important to economic growth and development because they have the potential to bring "new" money into the county. This imported money, as it circulates throughout the economy, is able to support, by way of a multiplier effect, a more extensive eronomic service sector. Eventually employment expands as does income levels. With the tourist industry in DeKalb County receiving $\$ 4,677,389$ in 1977, it appears that tourism and recreation could become the second most important sector in DeKalb County's economy.

Table XIII-21 shows that the percentage of eimployment in mining in DeKalb Counly is below that of the development district and the state of Tennessee. The importance of mining as an industry and as employment has been diminishing steadily. Competition from other more mechanized areas, inferior quality ore, virtually mined-out resources, and lack of inexpensive river txansportation have relegated the county's mining industry to a position of providing for local needs. Recently, a new interest has arisen in zinc and petroleum along the highland rim, and many leases have been acquired. In spite of these new mining leases, the industry is predicted to remain in its present state within DeKalb 
County. The proximity of neighboring more active mining areas in the UCDD, such as Smith County, possibly could result in an increased outmigration to these areas of presently unemployed workers whose skills were gained originally in DeKalb County's earlier resource-oriented economy.

Table XIII-26 summarizes the major employment changes that have transpired within the past 10 years in DeKalb County. The civilian labor force has increased steadily since 1968 (except in 1975), along with total employment. Even though the employment rate has fluctuated in response to national and state economic trends, it was consistently higher than the Tennessee figure until 1976, at which time it dropped below the state figure. Compared to the UCDD, DeKalb County has experienced a lower unemployment rate each year since 1966, except for 1970 (see Table XIII-27). The decreasing trend in unemployment is partly due to the stabilization of the agricultural industry, along with greater job opportunities in the trade and service sectors, resulting especially from increases in tourism in the Center Hill Lake area.

Unemployment figures for DeKalb County (shown in Table XIII-27) understate the real problems. They are low because in the past a tremendous number of people have sought work outside the county and therefore have registered in such places as McMinnville, Murfreesboro, Cookeville, or Nashville for unemployment. The good transportation system available within the UCDD, and DeKalb County's proximity to Highway I-40, allows the population to commute to jobs in adjoining counties with ease. The actual daily inter-county commuting between DeKalb County and the remainder of the UCDD has been increasing. In 1960, 84 percent of the county's employed residents were employed within the county and 91 percent of the jobs in the county were filled by county residents. But as the availability of manufacturing jobs in DeKalb County and the remainder of the UCDD increases, these numbers are decreasing rapidly. Still, the number of DeKalb County residents employed outside the county is greater than the number of nonresidents employed within the county, because of the attraction of DeKalb as a desirable place to live with a peaceful atmosphere. This 
TABLE XIII-26. LABOR FORCE ESTIMATES. FOR DEKALB COUNTY [a]

\begin{tabular}{lrrrrrr}
\hline & 1968 & 1970 & 1972 & 1975 & 1976 & 1977 \\
\hline Civilian labor force & 4,630 & 4,780 & 4,890 & 5,530 & 5,450 & 5,500 \\
Total Employment & 4,410 & 4,460 & 4,640 & 4,990 & 5,160 & 5,228 \\
Unemployment & 220 & 320 & 250 & 540 & 290 & 272 \\
Unemployment rate & 4.7 & 6.7 & 5.1 & 9.8 & 5.3 & 4.9 \\
Nonagricultural & 3,710 & 3,780 & 3,720 & NA & NA & 3,470 \\
Agricultural & 710 & 680 & 920 & NA & NA & NA \\
\hline
\end{tabular}

[a] Source: State of Tennessee [1972]. 
TABLE XIII-27. ANNUAL AVERAGE UNEMPLOYMENT RATE (\%) [a]

\begin{tabular}{lccc}
\hline Year & Tennessee & UCDD & DeKalb \\
\hline 1966 & 3.2 & 4.1 & 4.0 \\
1968 & 3.9 & NA & 4.7 \\
1970 & 5.5 & 5.1 & 6.7 \\
1971 & 3.9 & 6.5 & 6.2 \\
1975 & 8.4 & 11.3 & 9.8 \\
1976 & 6.0 & 7.1 & 5.3 \\
1977 & 5.2 & 5.9 & 4.9 \\
\hline
\end{tabular}

[a] Source: State of Tennessee [1972]. 
trend can be expected to continue, except that more jobs will be opening in DeKalb County than in the remainder of the UCDD, thus attracting commuters and/or in-migration.

\section{PUBLIC FACILITIES}

Adequate public facilities are an essential factor in the growth potential of DeKalb County. If new residential, commercial, and industrial development is to take place without polluting the natural beauty of DeKalb or overcrowding the existing community facilities, it is necessary to know the capacity of these facilities and utilities.

\section{Water Supply}

The reader is referred to Section $X$ for a description of community water services serving DeKalb County and the surrounding area.

\section{Wastewater Management}

Only Smithville and Alexandria are presently served by a sanitary sewer system. A new wastewater treatment plant is presently in operation and over 100,000 feet of new sewer line has been added to the old system. Current usage is 500,000 gpd. The present capacity of $2 \mathrm{mgd}$ is expected to provide adequate treatment facilities for the next 20 years.

Alexandria has completed a new public sewer system which will fulfill the needs of a population of 1,500, or nperate effectively until 1995 . The sewer uses a contact stabilization process and the effluent is discharged into Hickman Creek.

The growth in second home development in the Center Hill Lake area has resulted in the need to seriously consider sanitary sewers in this locality. 


\section{Solid Waste}

Solid waste in the area is handled by a landfill site located 3 miles west of Smithville combined with an existing containerized program.

\section{Schools}

There are 2 elementary schools in DeKalb County. The Smithville Elementary School has a capacity of 700 students, and the new Western Elementary School has a current capacity of 450 students. DeKalb County High School and the DeKalb County Middle School serve the entire county. The high school is in sound condition and is capable of accommodating 700 students, while the middle school can accommodate 800 students in Grades 5 through 9. There is also a vocational school that trains students in auto mechanics, sheet metal, air-conditioning, refrigeration, general building, and office occupations; it has a capacity of 350 .

\section{Health Facilities}

Except for one part-time doctor in Alexandria, all other medical facilities of DeKalb County. are located in Smithville. There are two hospitals in Smithville with a combined capacity of 84 beds; another 15 beds will be needed by 1990. The Health Department facilities at Smithville are expected to provide adequately for the city's need during the next 20 years. There are currently six people employed at the Health Department.

\section{Fire Protection}

Present fire protection capability is adequate for DeKalb County as a whole. Smithville has adequate fire-fighting capability, but its firefighting equipment is not permitted beyond the city limits. The towns of Alexandria and Liberty also have fire-fighting equipment. Presently, however, no fire protection exists for the remainder of DeKalb County, creating a hazardous situation for citizens residing outside the above 
municipalities. These outlying areas of the county are partially protected by the TVA-Rural Fire Protection Program which locates rural fire trucks in central locations.

\section{Police Protection}

The Smithville Police Department employs six men full-time, and has two patrol cars. Alexandria has a three-man police force and one vehicle. The rest of the county is protected by the DeKalb County Sherriff and his three deputies. The rural districts of the county are also protected by two state troopers and seven constables.

\section{$\underline{\text { Recreation Facilities }}$}

With the help of the Model Cities Program and the Farmers' Home Association many new recreational use facilities have been built during the past few years. There are eight parks and ten community centers in DeKalb County. There is a park and a community center in Dowelltown but the former is located too far from the population center to serve it well, and another is needed closer to the center of town. The DeKalb County fairgrounds are located in Alexandria, and an Open Space Park is located on Hickman Creek, which is easily accessible to Alexandria's residents because of its central location. There are has several parks and a country club in Smithville to provide recreational activities for its citizens. In addition to these parks, the high school offers a gymnasium and football field. Table XIII-28 summarizes the recreation facilities of DeKalb County.

\section{Transportation}

\section{Surface Roads}

There are 1,472 miles of roads in DeKalb County. One of the two major thoroughfares in the county is U.S. Highway 70S (State Route 126) traveling east-west through Liberty, Dowelltown, Alexandria, and Smithville. This route carries an average daily traffic (ADT) volume of approximately 
TABLE XIII-28. LOCAL PUBLIC USE RECREATION FACILITIES OF DEKALB COUNTY [a]

\begin{tabular}{|c|c|c|c|}
\hline Type Facility & Location & Facilities & Status \\
\hline Open Space Park & Dowell town-Liberty & $\begin{array}{l}\text { Picnic, softball } \\
\text { playground equipment }\end{array}$ & Open \\
\hline Open Space Park & Alexandria & Picnic, playground equipment & \\
\hline $\begin{array}{c}\text { Open Space Park } \\
\vdots\end{array}$ & $\begin{array}{l}3 \text { miles midway east } \\
\text { of Smithville }\end{array}$ & $\begin{array}{l}\text { Picnic, basketball, tennis } \\
\text { softball, tot lot }\end{array}$ & Open \\
\hline Open Space Park & Airport (Śmithville) & . & Open \\
\hline Open Space Park & Broad St. (Smithville) & & Undeveloped \\
\hline Community Center & Snow Hill & Indoor facilities & Open \\
\hline Community Center & Temperance Hall & Indoor facilities & Open \\
\hline Community Center & Midway & $\begin{array}{l}\text { Indoor facilities, } \\
\text { playground equipment }\end{array}$ & Open \\
\hline Community Center & Johnson Chapel & $\begin{array}{l}\text { Indoor facilities, } \\
\text { playground equipment }\end{array}$ & Open \\
\hline Community Center & Belk & $\begin{array}{l}\text { Indoor facilities, } \\
\text { playground equipment }\end{array}$ & Open \\
\hline Community Center & Blue Springs & $\begin{array}{l}\text { Indoor facilities, } \\
\text { playground equipment }\end{array}$ & Open \\
\hline Community Center & Keltonburg & $\begin{array}{l}\text { Indoor facilities, } \\
\text { playground equipment }\end{array}$ & Open \\
\hline Community Center & Dowell town & $\begin{array}{l}\text { Indoor facilities, } \\
\text { playground equipment }\end{array}$ & Open \\
\hline Communịty Center & Liberty & $\begin{array}{l}\text { Indoor facilities, } \\
\text { playground equipment }\end{array}$ & Open \\
\hline$\underset{i}{\text { Community Center }}$ & Smithville & $\begin{array}{l}\text { Indoor facilities, } \\
\text { playground equipment }\end{array}$ & Open \\
\hline Recreation Park & $\begin{array}{l}\text { Old Smithville } \\
\text { Country Club }\end{array}$ & $\begin{array}{l}\text { 9-hole golf course, club } \\
\text { house, swimming pool, tennis, } \\
\text { playground equipment }\end{array}$ & Open \\
\hline Recreation Park & $\begin{array}{l}\text { Oaklawn Park in } \\
\text { Smithville }\end{array}$ & $\begin{array}{l}\text { Picnic, softball, basketball, } \\
\text { playground equipment }\end{array}$ & \\
\hline Recreation Park & $\begin{array}{l}\text { Green Brook Park } \\
\text { in Smithville }\end{array}$ & $\begin{array}{l}\text { Picnic, outdoor stage, } \\
\text { playground equipment }\end{array}$ & $\begin{array}{l}\text { Under } \\
\text { Construction }\end{array}$ \\
\hline
\end{tabular}

[a] Source: UCDD. Outdoor Recreation Plan. Model Cities Office, Smithville, Tennessee. 
2,300 vehicles, according to the Tennessee Department of Transportation. By 1990 , this ADT volume may reach 4,600. Plans are now underway to widen this road to four lanes. The other major arterial in DeKalb County is State Route 56, running north-south. It not only serves as an intra-county road, but also connects DeKalb County with Interstate 40, and indirectly with the Nationwide Highway System. The intersection of these two highways in Smithville forms a hub of vehicular and economic activity. Another highway running into Smithville is State Route 146, which traverses the southwestern portion of the county.

State Collector Roads 141, 146, 26, and 96 collect traffic from the smaller towns and populated rural areas and provide access to arterial routes 56 and 70S. Many of the secondary arteries and collector roads in the less-traveled areas are in poor condition and need to be paved, widened, resurfaced, or reconstructed. Major features of the DeKalb County transportation system can be discerned in Figure VII-1.

\section{Waterways}

When the Caney Fork River was impounded in 1948, the only avenue of intra-county water transportation was eliminated.

\section{Airports}

The one airport in DeKalb County is located in Smithville. It is a public facility that serves noncommercial flights, and charler and taxi service. The a1rpurl has a 2,400-foot long, 75-foot wide paved runway. Though the Smithville airport is not adequate for commercial airline service, it is expected to satisfy the needs of private aircraft operations and business planes in the future. The Nashville Airport, which is within 60 miles of DeKalb County, is capable of handling future commerciall needs. 


\section{Bus Service}

Bus terminals are located in Smithville, Alexandria, Liberty, and Dowelltown. The users of the inter-county bus lines are primarily persons over 55 years of age or under 24. These riders are generally single and have relatively low incomes. As the population ages, it will be necessary to expand the provision of bus service.

\section{ANALYSIS OF IMPACTS}

The manner in which a new industry affects the human environment in which it is situated is enormously complex. Effects range from the direct, obvious and tangible, to the indirect, subtle and intangible. The contemplated uranium shale mining and processing project will have both direct and indirect impacts upon the land use, economy and population of the study region. In fact, many anticipated effects can be expected to interact to the extent that they may be viewed as causes rather than direct effects from the introduction of the new development project.

Social and economic impacts of the proposed project will affect two different size regions: the local, or immediate (DeKalb County); the intermediate, or 65-mile community radius. Impact analysis of these two different size scales is complicated by intervening political boundaries and some physical differences, yet each of the two different areal units complements the other's labor and commercial needs.

The effect of the industry in question upon the socioeconomic characteristics of the study region are conceived as "impacts" attributable to specific features of the industry's location, operations, and inputs/ outputs. The direct effects resulting from these impacts are those arising from the mere existence of the facility as well as its construction, operations, and maintenance. These direct effects include the goods and services purchased by the industry, employment, and the environmental changes that occur due to the existence of the mines and processing plants. 
Specifically, direct socioeconomic impacts are defined to include the expected employment opportunities directly associated with the development of the project, as well as the population growth and income changes expected to result from these new jobs. Two other significant direct changes are the anticipated increases in the local tax base and alterations to the previous land uses resulting from the physical existence of the project. All other changes are derivatives of these direct impacts.

The indirect effects include what may be considered induced or casual changes. For example, the population growth associated with new employment opportunities is expected to stimulate periphery consumer services and trade, new housing construction, overburdened schools, and indirect land use changes. Indirect impacts affect the immediate or intermediate study area relative to the location of the mining and processing plants, and the residential location of direct employees.

A project of such vast operations and output will foster dramatic impacts upon the economy and social characteristics, or quality of life, in DeKalb County as well as in surrounding counties. The influence upon the lateral environment of DeKalb County and the study region from the extrartion and processing of uranium shale can be expected to maintain significance throughout the life of the project, and after its termination.

To accomplish the analysis for DeKalb County, it has been necessary to formulate assumptions regarding the percentage of the labor force expected to relocate in DeKalb versus the percentage expected to comnule during construction and operation phases; average salaries for miners and processing plant operators; and the number of jobs expected to be generated as a result of the project.

Whenever these and other assumptions are made to facilitate the analysis, they are carefully explained and specifically rationalized. This following discussion, therefore, provides estimates of potential impacts and should not be considered an exact calculation of the effects. To determine certain specific effects, studies in greater detail will be necessary 
to determine actual values to replace the assumptions made herein. This discussion provides primarily an estimate of the magnitude of anticipated impacts .

Not all impacts discussed below are quantifiable. The different effects upon each area will be quantified where possible by their components, but in all cases a general evaluation of the magnitude and direction of the impacts will be made for the individual impact variables. The hypothetical nature of the proposed project and the limits of the data base make certain assumptions necessary to this objective.

\section{EMPLOYMENT}

\section{Direct}

Employment opportunities associated with the construction, mining, and processing of uranium shale will constitute the major direct projectrelated influence upon the economy of DeKalb County and environs.

\section{Construction}

It is estimated that construction of the proposed project will require approximately 2,000 to 4,000 workers, commencing in 1983 and reaching a peak within 5 years, then gradually decreasing over the last year. The same workers will not be employed over the entire 7 years, since different trades will be required at various stages of the project.

\section{Operations}

Assuming that construction will extend over a 5-to-7 year period, the operating phase will begin in 1990. Approximately 60 clerical, supervisory, and technical employees will be working by 1989 . The 240 maintenance and 300 machine and circuit operators will commence working upon termination of construction in 1990. Employee turnover will average about 5 percent a year. To maintain the mines operating continuously ( 7 days per week), 2,400 people will be employed 5 days per week. 
Indirect

The number of indirect jobs resulting from direct project employment will be considerable in both DeKalb and surrounding counties. The distribution of these indirect jobs will be determined primarily by where direct project workers choose to live. The distance a shopper is willing to travel to purchase goods or services is different than the distance a worker is willing to commute to a job. Therefore indirect jobs will tend to locate near the direct project workers' residence rather than near the project site. Hence, the more employees living in DeKalb County, the greater the impact upon the local economy.

Increased demand for goods and services, increased wages, and increased capital in circulation may inflate the local economy. However, the proximity of several major urban areas should prevent the manifestation of a "boom" economy. Most boom situations result from isolated mining activities where all workers are forced to live in and depend upon the immediate community. When this occurs, all impacts are focused upon one area, resulting in changes which cannot be immediately assimilated by the community or region. In these situations, growth limitations which usually reeult from insufficient additional social and economic carrying capacity in an area, do not occur since population demand cannot be channeled to nearby towns. In the case of the contemplated project, impacts are expected to be spread out over an intermediate region determined by the commuting radius of approximately 65 miles. (This assumed radius is based upon the market area for available labor, and distance travelled by up to 20 percent of DeKalb County's current work force.)

\section{Construction}

The percentage of direct workers locating in DeKalb County depends upon certain variables such as housing availability and quality of life. For the purposes of this study it is assumed that 65 percent of the construction force (2600) will commute from surrounding counties to DeKalb County, and that 35 percent ( 1400 workers) will locate in the county. 
These percentages are based upon the following characteristics of the intermediate region and the construction force. These listed characteristics are described in greater depth elsewhere in the report.

1) The average worker in the construction trade locates his family in one place and will commute a radius of 60 to 70 miles for work.

2) The construction phase lasts only 7 years and few workers will be employed there for more than 4-to-5 years, with specialty and finishing contractors brought in during the final year.

3) There is an inadequate housing supply in DeKalb County.

4) An insufficient supply of good and services has resulted in higher prices in DeKalb County.

5) Commuting time to population centers is shortened by a good transportation system.

6) Only 600 construction workers currently live in DeKalb County; the quota would have to be filled by workers settled in nearby areas.

Patterns of employment in a given geographic area reveal a fairly constant relationship between employment directly generated by production activities and induced employment. Therefore, a generalized multiplier of 1.6 for mining activities located in rural areas has been used herein to determine indirect employment resulting from the project. Using this multiplier (ratio of total employment to basic employment), it is possible to project the increase in total employment which will occur with an increase in direct employment. Most service and commercial activities in rural areas have excess capacity. Hence, an increase in direct employment has a relatively smaller impact upon indirect jobs in rural areas than it does in urban areas. Therefore, the economic growth stemming from the construction phase of the project is expected to produce a numerically 
larger impact upon total employment in the intermediate region than in DeKalb County. However, the overall percentage change in population will be relatively larger for DeKalb County.

Indirect employment resulting from the construction phase is expected to reach 6400 jobs within the entire commuting region, with 2240 of these jobs located in DeKalb County. Thus, total new employment during this phase will be approximately 10,400. Of these jobs, 3,640 new jobs will be generated in DeKalb County, and the other 6,750 jobs apportioned throughout the commuting (intermediate) region.

\section{Operations}

As the project progresses into the operations phase, the percentage of directly employed workers living in DeKalb County should approach the percentage commuting in from other counties. Based upon the following variables, this study assumes that 50 percent of direct operational employees will live in DeKalb County:

1) The operating phase has a 20-year lifespan. This will allow for a more stable economy and increase the attractiveness of DeKalb County as a location in which to settle permanently.

2) Smithville, which is adjacent to the mining area, has an aggressive policy towards attracting new population and jobs.

3) DeKalb County is already serviced by sewers and water lines which can encourage development, while surrounding counties are not nearly as well provided with these services.

4) By the end of the construction phase, the DeKalb County will have fulfilled a much greater percentage of the unmet housing needs due to the 7-year preparation period for the operating workers. The county will have adjusted to the increased 
demands for housing and services made by the construction force, thus making it a more inviting permanent location for the miners and operating personnel.

5) The 50 percent of direct operational employees living in surrounding counties will permanently locate there because:

a) they have already established their homes there, b) the housing capacity in DeKalb County will not accommodate everyone, c) the mining acquisition of land and aesthetic impacts may stimulate people to seek a better quality of life in an adjacent county and commute to DeKalb County to benefit from employment opportunities, d) the economy may become inflated in DeKalb County because of rising demand, making it cheaper to live in surrounding counties while receiving an income in DeKalb.

Using the same multiplier of 1.6 , indirect employment during the operations phase will be approximately 5,120 of which 50 percent (2560) jobs will occur in DeKalb County. Therefore, a total of 8,320 new jobs in the entire intermediate region will be generated from the operations phase. Half of these will open up in DeKalb County. The impact that these new jobs will have upon the quality of life and economy of the county is explained in more detail later in this section.

While direct employment will stabilize during the operations phase, indirect employment opportunities will increase because of other industries and employers taking advantage of the locational factors developed in DeKalb County for the project.

\section{Sectoral Analysis}

The general effect of the employment impacts can be better understood when analyzed by employment sectors. The relatively undeveloped economy of DeKalb County and surrounding counties will become more sophisticated and complex as the population growth attributed to new employment opportunities makes it both economical and necessary to develop. Of course, 
the proximity of distribution/ regional service centers such as Nashville and Chattanooga will limit the type and number of indirect employment opportunities available in the local economy. These cities will continue to attract the major medical supplier and wholesale activities of the intermediate market area. Since it is projected that the proposed project will purchase equipment and materials on a national level rather than regionally, corresponding employment gains in the regional cities will be negligible.

\section{Agriculture Sector}

Agricultural employment will continue to decrease as the mining project acquires at least 12 square miles of land in the farming district of the county and pays royalties on another 1600 acres per year. Currently (1978), only 15 percent of the county's farmers depend solely upon their farm income. The other 85 percent are subsistence farmers that supplement their income with part time jobs. When these farmers are faced with job opportunities paying over triple their present income, it is expected that there will be a major transfer from farming to mining/industrial employment. This trend has already begun as the availability of manufacturing jobs in DeKalb County increases.

While agriculture will continue to decline as a source of employment, many people will continue to farm for their own use. Other farmers will be able to expand current subsistence operations by consolidating with adjacent farmers who choose new employment opportunities. In addition, a few subsistence farmers will either retire or continue their farming because of the supplemental income they will receive from mining royalties.

Assuming that 85 percent of the 1970 subsistence farmers will no longer be employed as farmers in 1985, agriculture will drastically decrease as a percentage of total employment, from 12.8 percent in 1970 to less than 1 percent. 


\section{Industrial Sector}

The introduction of the proposed project will not directly impact the local economy, but. will generate potential economic stimulus by causing improvements to the infrastructure of the county. More paved roads, more regularly scheduled truck transport to the county, the potential for a rail line into the county, improvements in the skills of the labor force, and potential use of by-products of the plant would all combine to create an improved climate for other industrial activity; hence the increased employment opportunity.

Currently the growing industrial sector consists primarily of producers of nondurable goods. Most of the jobs offered by these industries are filled by women. In fact, 80 percent of all new industrial growth has hired women. Therefore, DeKalb County's aggressive policy of attracting industry has found it necessary to discourage many companies that employ mainly women, in favor of seeking industries that hire more men.

The creation of 4,000 construction jobs followed by 3,000 long-term mining and processing jobs will effectively eliminate the male unemployment problem in DeKalb County in addition to significantly increasing the available female labor force. In the past, low per capita incomes have been alleviated somewhat by women entering the labor force to add a second income to the household. With the introduction of the contemplated project, the high project wages will result in lower female labor force participation roles (LFPR). Due to this lower female LFPR there will be a numerically larger female labor force than without the project.

Therefore, it is expected that industrial job opportunities will increase to take advantage of this surplus labor force.

The number of industrial jobs is expected to increase, even though the percentage of total employment will stabilize or decrease due to the tremendous increase in mining, construction, and smaller, but steady gains in other sectors. 


\section{Service and Retail Sectors}

The expansion of the population and per capita income will provide the economic stimulus to support more extensive service and retail sectors. Increased wages will stimulate the expansion of the service industries such as dry cleaners, barbers, theaters, fast food chains, restaurants, bars, lawyers, accountants, etc. More money circulating in the local economy will in general increase retail sales, investments, savirgs, and bank deposits, thus stimulating the growth of the financial-banking services in the area.

The growth of these sectors will be based primarily upon the personal shopping service, and entertainment needs of the expanded population, as well as small scale support services and businesses necessary for operation of the mines and processing plant.

With the generation of 2,560 new indirect jobs in DeKalb County, the importance of the service retail sectors will increase substantially. However, the proximity to Nashville and Murfreesboro will act as a disincentive for these sectors to develop beyond local needs. During construction, both sectors will experience rapid growth to accommodate the demand exercised by the new levels of the population; and then reduce their growth rate during operations. Similar effects will be felt by towns and cities in surrounding counties that serve employees commuting to the project site in DeKalb County.

\section{Construction sector}

The addition of 4,000 direct construction jobs between 1983 and 1990 will establish this sector as a dominant force in the intermediate local economies. In DeKalb County, 1,400 construction workers will increase this sector from 11.74 percent of total jobs in 1970, to about 44 percent during the construction phase. Even though there will be a major reduction in the number of construction jobs as the operating phase begins, this sector will still constitute a healthy percentage of the total labor force. 
Due to the length of the construction phase and continuing construction opportunities to satisfy economic and population growth demands, it is reasonable to assume that at least 40 percent of the project's 1,400 direct construction workers living in DeKalb County will remain there, having made attachments and become settled. Some of these will have been employed up to 6 years on the project, while many others may have been residents of the county even before the project. Many of the remaining construction workers will be absorbed into direct or indirect operating phase jobs, while still others will work on new housing, commercial, and infrastructure construction emanating from overall population growth.

The 40 percent who elect to remain in DeKalb County, will possibly exist in a labor-surplus economy and therefore may eventually move on to other construction jobs in other regions. The majority of the construction crew commuting from surrounding counties will most likely continue to commute to other construction jobs within their commuting region. If the demand for uranium were such that other processing plants and refineries were needed within the study region, it is probable that most of the construction workers would either commute, or relocate to construction sites located within the regional study area but outside the intermediate region.

\section{Mining Sector}

Obviously the most noticeable of all project-related employment changes will be experienced in the mining sector. The importance of mining to the region has steadily declined in the past until in 1970, only a few workers commuted to zinc mines in nearby counties. The introduction of uranium shale mining will dramatically increase the employment figures for this sector to 2,600 by 1990 (when operations begin); 1,300 of these workers will live in DeKalb County. Not only will mining and related activities constitute the largest percentage of total employment in DeKalb County, but the contemplated operation will also be the single largest employer in the county. 


\section{Recreation Sector}

All mining and processing activities except for the disposal of tailings are expected to occur in the southern portion of the county. Tourist recreational-activities presently are located principally in the northern and northeastern portions of the county and consequently will not be significantly affected by the project. The only negative effect to the recreation sector may be the visual impact of the tailings disposal areas. Two positive impacts may be: 1) the increased visitations resulting from population increase; 2) the value of reclaimed tailings disposal areas for recreational uses, such as a golf course. Since the entire mining and processing operation will be required to meet Federal and state environmental regulations and standards, there are no foreseeable impacts on water quality. Hence, water-related recreational uses such as fishing, swimming, boating, and water skiing are not expected to be adversely impacted.

\section{Employment Summary}

Increased economic opportunity in the intermediate and especially the local region will enable training or retraining of much of the unemployed labor force in the area. In the short run, new skills and training will serve to increase the standard of living and the health and welfare of the general population. Moreover, in the long run, the region may become characterized by a specialized economy with a skilled technicallyoriented labor force. This type of labor force may attract more durable (versus non-durable) goods industries to DeKalb County, which will help the economy to diversify and grow. If the county and region do not carefully guide the anticipated economic development, this type of specialization could be particularly sensitive to cyclical changes in demand for products. Fluctuations in the local economy may also occur with a depletion of the more accessible mineral resources, unless a diversified economic infrastructure grows with the mineral development. 


\section{INCOME}

The size of the direct labor force required for the construction and operation of the contemplated uranium shale project indicates that a considerable increase in personal income can be expected in DeKalb County as a result. Income estimates for a future population are always made with some uncertainty because of inflation, demand/supply of labor, and fluctuations of the economy. In spite of these forecasting problems, an approximation can be made of the expected impact of the project upon purchasing power in the area.

Roughly $\$ 2.3$ billion (1978 dollars) will be required to establish one recovery complex, including the construction of one processing/refinery plant, development and equipping of three mines to feed this plant, and provision of ancillary components such as land, dams, power lines, taxes, and royalties. The only portion of these capital expenses to be siphoned into DeKalb County are taxes, royalties, and wages and salaries of construction workers. Most equipment and materials will be purchased at the national level. When combining this total with operating costs, the major economic impact upon DeKalb County will be in the form of job opportunities and increased income.

\section{Construction Phase}

Utilizing the projected construction schedule, rough estimates can be made of the expected direct personal income resulting from the construction phase of development. During peak construction periods for the project, it is estimated that a maximum $\$ 7.4$ million in construction wages will be paid annually. Of this total, only $\$ 2,590,000$ will be added directly to DeKalb County's total personal income, since only 35 percent of the construction force will live in the county. The lack of data concerning average incomes of indirect employees precludes this study from quantifying the indirect and, therefore, total impact upon personal income in DeKalb and surrounding counties. 
While per capita and median household incomes cannot be determined, it is possible to project generally the impacts. "Due to the high direct project salaries, both the per capita and median family incomes for DeKalb County should rise significantly, increasing to levels above the state average. Although the increase in personal income resulting either directly or indirectly from the project will affect positively the vast majority of DeKalb residents, not all people will benefit. The growing retirement population will be affected by the inflated cost of living stemming from a higher average disposable income and subsequent increases in buying power. The people existing on a fixed income will experience a relative decrease in their buying power.

Property income definitely will increase numerically and as a percentage of total personal income sources because of higher land values associated with a growing area, the proximity to the project and insufficient supply to meet demands for land. Also the uranium royalties from the mining operations will add to the increases in this source of personal income.

\section{Operations Phase}

Personal income to be generated from direct operational mining employment is estimated at $\$ 62.4$ million annually, of which half is expected to go toward DeKalb County's total personal income. In addition, income generated by growth of indirect jobs will raise further total personal income. Median household income will increase far beyond previous levels bccoure of higher per rapita income and the greater percentage of job opportunities. The latter will stimulate a higher female labor force participation rate than would exist without the project. The business community may not receive maximum possible benefits from the increased income, because people may travel to larger trade centers such as Nashville (or even Cookeville) to make their purchases. Throughout the life of the project, the population of DeKalb County will have a greater purchasing power than the state as a whole since the percentage of households in the high income groups will far outweigh those in the low income groups. 
Total income generated by the operations phase of the project will be less than that generated by the construction phase, but a larger percent of this total income will be distributed in DeKalb County during the operations and mining phase. Therefore, the amount of direct income available in the county during operations will generate more spending. Consequently, a higher indirect employment level can be expected resulting in an overall increase in indirect income. Since more money will be available for spending in more places at a greater turnover rate, the economy will experience a slight but steady expansion during the operations phase.

\section{Sources of Personal Income}

The sources of personal income in DeKalb County will be altered as a result of the project. The emerging trend of wages and salaries as the major source of personal income in the $1960^{\prime}$ 's will continue with the addition of 1400 construction workers, followed by 1600 miners and other personnel who receive wages and salaries. Farm income will decline as a percentage of total personal income as fewer farmers sell. their crops and more farms are sold for development. Total income of nonfarm proprietors will increase both numerically and as a percentage of total personal income, corresponding to the growth of indirect business trade and services (which are expected to rise).

As the unemployment rate drops, income levels rise, and a younger population enters the county, transfer payments will reverse their previous growth rate. These will decline as a percentage of total personal income sources even though they will increase in magnitude. Increases will go toward a larger government employment force, unemployment benefits between the construction and operations phase, and more medical benefits.

The exact taxes to be paid by the project cannot be accurately determined at this time. Taxes paid by the project may lower the overall tax rate and the actual taxes paid by the rest of the county. Even though the tax 
rate may decrease, the total tax revenues can increase to a level necessary to satisfy the new requirements for public services and utilities. Hence, higher tax revenues will be received from the project rather than levied against the general prosperity of the population. This will have the effect of allowing a larger percent of personal income to flow into the economy than would be possible if the project did not exist.

\section{POPULATION}

New jobs in an area can generate population growth if the number of jobs generated by a project is substantially above the available local labor force, or if locally unavailable specialized skills are required. The resulting population increases may generate even further job opportunities. In situations where both rapid growth and population composition are dramatically changing, the impact upon the community affects the quality of life, range of economic opportunities, social activities, and social/ political issues.

The introduction of the uranium shale mining and processing operation into DeKalb County will require a labor force of approximately 4,000 construction workers. Prior to the project, approximately 560 persons will be employed in the construction industry. Most of these will be needed during the construction phase of the project to build houses and commercial buildings and expand public facilities and services as required by population growth. A population of 12,000 is projected for DeKal,b County in 1986 without the proposed project. An addiliullal 1,400 consiruction workers and 2,240 indirect employees are expected to locate in the county during the construction phase of the project. Assuming an average household size of 3.0 this will add 10,920 people to DeKalb's population in 1986 (peak of construction phase), resulting in a total population of 22,920 .

The extended length of the construction phase plus the proximity of Nashville and other population centers within 65 miles offers DeKalb 
County a certain lag period during which housing and infrastructure expansions needed to assimilate the new population and develop a viable social and economic base can be accomplished. Based upon the assumption that the county will prepare itself for the greater growth rate anticipated during the operations phase, it is projected that 1,600 direct employees will locate therein, along with 2,560 indirect employees. In addition, approximately 560 project construction workers that previously moved. into DeKalb with their families will remain there during the operations phase. Using an average household size of 3.0 adds 14,160 people to the 12,000 people projected to live in the county without the project. Thus DeKalb's population is expected to increase from 11,151 in 1970 , to 22,920 in 1986 , and to 26,760 in 1993 (see Table XIII-29).

Table XIII-29 shows that the population is expected to grow by 101 percent during the project construction phase and at least another 17 percent during operations. The construction phase will promote the greatest impact upon population change and corresponding social stability, quality of life, and economic opportunities in DeKalb County because of the initial "shock" to the existing population. However, it is the operations phase that will add the largest total population increment to DeKalb's projections without the project. The numbers in Table XIII-29 do not clearly portray this impact since the outward-migration of many of the 1986 population and the in-migration of new people will occur before reaching the 1993 population projection.

The total population of the intermediate study area is not expected to increase significantly beyond existing projections without the project due to the existing labor pool available within a 65 mile radius. This labor pool, which should adequately supply projected employment requirements, will increase the immediate area population through "intraregion". (intermediate) migration. The availability of a construction labor force in the intermediate region is dependent upon the completion of construction of the Hartsville Nuclear-Power Plant by 1983 so that this mobile construction force can move or commute to DeKalb County. 
TABLE XIII-29. PROJECTED. POPULATION INCREASES IN DEKALB COUNTY

\begin{tabular}{lccl}
\hline & Population & \% Change & Economic Stimulus \\
\hline 1940 & 14,588 & & \\
1950 & 11,680 & -7.8 & agriculture \\
1960 & 10,774 & -7.8 & agriculture \\
1970 & 11,151 & +3.5 & industry \\
1980 & 11,400 & +13.9 & industry/diversification \\
1986 & 22,920 & +101.0 & construction \\
1993 & 26,760 & +19.0 & mining \\
& & & \\
\hline
\end{tabular}


Most of the new employees locating in DeKalb County will be attracted to the stability offered by the project and bring their families with them. Most of the construction force will be composed of contractors and other workers employed throughout most of the construction phase. The family orientation of these employees will affect the schools and growth potential of DeKalb County.

A change in the composition of the population can be expected as abundant employment opportunities induce a working age (18 to 62) population to stay in DeKalb or in-migrate from other areas. The greatest increases are expected to occur in the younger, productive age groups (18 to 35 ), which will reverse the existing trend toward an aging population. Such a reversal of age structure will have a tendency to spiral as natural increases among the new population take the place of declining increases in in-migration once the operations phase is underway. This growing birthrate will help to insure a bright future for DeKalb. Other changes in the population composition will likely include slight increases in racial mixture and percentage of males. The impact of the altered population composition upon infrastructure is discussed in a later segment of this section.

The low-median education and outward migration of the younger (more educated) population of DeKalb County (before the project) will be drastically affected due to the educational level of the in-migrating labor force. Perhaps 20 percent of direct employees will possess undergraduate college degrees, and 80 percent will have high school or technical school degrees. In addition, the project will offer training programs for inexperienced personnel. This better educated public will provide a more attractive labor force for other industries and businesses, increase income levels and require a more varied socio-cultural environment in which to live.

DeKalb County will continue to acquire an increasingly urban character as the population expands and farmers sell their land for other uses such as mining. Yet, simultaneous increases in the rural population will result from the general expansion of countywide population. 
HOUSING

The present supply of housing in DeKalb County has a limited capacity to absorb additional population. Less than 1 percent of the standard housing stock is available for rent and even fewer standard homes are for sale. Approximately 50 houses per year are being reinhabited through Production Credit Association and Federal Housing Assistance loans.

In spite of the housing shortage in DeKalb and surrounding counties, the potential for tremendously improved housing conditions exists for the expanded population. The increased employment and associated monetary income will provide the population with the means to construct new housing. Since the conditions necessary for development of new single and multi-family homes are more prevalent in DeKalb than any of the nearby counties, the probability of extensive development there is greater. Almost 98 percent of the municipal land in DeKalb:County soon will be served by water and sewer lines and there are over 5,000 vacant plotted lots available for development presently. Since the project may substantially modify the existing character of the underground aquifer which supplies private wells, water lines to mitigate the impact of mining upon the well water supply will be required.

While the housing situation in DeKalb County is better than that of surrounding counties, the possibility of an adequate supply of homes is still remote. If population growth in the county is going to parallel the growth potential of countywide employment opportunities, significant additions to the housing supply will be necessory.

Direct and indirect employment from the proposed project will generate an estimated 3,640 new households in DeKalb County during the construction phase, and 4,160 new households during the operations phase. Considering that the projected unmet housing need by the beginning of construction will have reached 1,547 units in the county, it is apparent that a major deterent to population growth will be available housing. A factor compounding this problem is the existence of the problem to an even 
greater extent in surrounding counties. Generally it is expected that most of the employees commuting from surrounding counties will continue to live in their present residences until new housing becomes available, rather than move closer to the site. This is especially likely during the construction phase in view of the scarcity of local housing.

The population influx expected to be associated with the project will produce an increase in the number of new housing units needed (unmet need) from roughly 1,547 to 5,187 during construction. At least another 1,080 household units will be needed by 1993 to house the projected operations-related population. In order to satisfy this demand, it will be necessary to build an average of 576 units each year between 1977 and 1986 (peak of construction). In preparation for the operating employees, the construction of an additional 270 units per year will be needed between 1986 and 1990 .

The chronic shortage of housing during the beginning of the construction phase will stimulate a housing construction boom since hundreds of new homes will be necessary to satisfy the growing demand. At an average of $\$ 38,000$ per new single family home, a total of approximately $\$ 238,000,000$ is expected to be spent on permanent housing for the operational level of employment and related growth. Undoubtedly, new trailer parks, multi-family residences, and apartment complexes will be essential.

A mobile home park would offer an alternative to commuting from nearby cities and allow a certain portion of commuters to live near the project during the week (and return home on weekends). It could be built rapidly in response to increased demand for housing. However the existence of one or more trailer/mobile home parks could detract from the present visual nature of the landscape and rural character of the county if not property regulated. Therefore, this type of solution to housing demand probably will be accepted reluctantly since residents are not expected to be willing to accept a trade-off between visual and economic impacts. 
The existence of a potentially stable housing market during the operations phase will make it profitable for developers to build new homes during the construction phase. In addition to meeting demand for additional housing, these homes will have an even higher value during the operation phase because the larger population will insure even greater demand and subsequently higher returns.

Families now living on the immediate operations site have to be relocated during the life of the project. These residents will lose their established residences. Whether or not this dissruptive relocation to improved housing is ultimately negative or positive in nature will depend upon the housing supply and quality.

In summary, there will be a significant housing shortage in DeKalb County at the beginning of the construction phase. This shortage will decrease in each subsequent year so that by the time operations commence, the balance between available houses and increased demand will be more receptive to population growth.

\section{LAND USE}

\section{Direct Impacts}

The proposed project will result in a direct impact upon the allocation of land uses in DeKalb County because of the project's ownership and utilization of land. Surface facilities (processing plant, mine entrance areas, conveyor belt route) will require approximately 10 square miles of land, not necessarily in one piece. Surface facilities will attract attention due to the height of mill structures, the presence of dust, and the sharp contrast of the facilities with the surrounding flat and rolling character of the agricultural landscape.

Underground mining with a room and pillar system is expected to utilize about 750 acres ( 1.2 square mile) per year. However, the 150 to 300-foot depth below surface level of most activities precludes all but two 
noticeable land use changes on the surface. The excavation of uranium shale by the room and pillar system may result in some subsidence which is not expected to materially affect surface land use. The only area that may be directly affected by the underground mining is that which is located near the ventilation shafts. The emission of toxic gases such as radon and methane from these shafts could force the project to acquire this land to prevent harmful environmental impacts upon nearby agriculture, wildlife, and human welfare. A small portion of the mining operations may involve strip mining where outcroppings are easily accessible at the surface. These open pit mines could consume approximately 50 of the 750 acres per year indicated in Section VII and result in both visual impact and surficial land use changes that can eventually be mitigated through reclamation by revegetation or installation of ponds.

The project will directly impact all land area needed to dispose of spent shale tailings and other wastes. Assuming that available technology will allow reintroduction of 70 percent of all tailings back into the mine, another 30 percent will have to be stored on the surface. Approximately 4,000 acre-feet per year, or 80,000 acre-feet over the 20 year life of the project, will require storage somewhere in DeKalb County, preferably within 5-to-10 miles of the processing plant. As discussed earlier, disposal of these wastes, if stored at an arbitrary depth of 100 feet, can be expected to cover an area roughly 800 acres ( 1 $1 / 3$ square miles) or greater in size.

It is projected that the tailings will be stored in the eastern or northeastern portion of the county, which is characterized by steep slopes and ridges. The creation of ponds, spoils piles, and tailings impoundments will contrast sharply with existing topography, thereby altering slope configuration and the drainage pattern of the area. The tailings impoundment and associated facilities (retention dams and rainfall diversions) will be designed to prevent contamination of water resources. If the tailings can be eventualiy solidified, the reclamation through revegetation would be achievable after a certain period of time. 


\section{Indirect Impacts}

Indirect land use changes are expected to occur as a result of the population growth associated with the project and the decreased supply of land. Peak operations phase population projections have been used to arrive at estimates for total land use demands in DeKalb County.

\section{Agriculture}

The location of the processing plant and most of the mining activity in the midst of agricultural land will disrupt an initial approximate 6,000 acres of land plus approximately 50 acres per year from open pit mining. Almost all of this land will be permanently removed from farming. The population centers of DeKalb County form a border between the level to gently rolling land in the south and the hilly northern portion of the county. Since there is already a severe shortage of rental and purchase homes in the county an additional conversion of agricultural land to permanent residences can be expected as new employees move in with their families.

The location of the tailings storage ponds in northwest DeKalb County will permanently, or semi-permanently, remove grazing land from the hillsides of the affected areas.

All marketable timber growing on the land used for tailings disposal processing plants, and associated facilities will be removed prior to commencement of operations. Over 7,000 acres of agricultural and forest land will be removed for project-related purposes. Consequently, agricultural and forest land will be reduced to less than 158,740 acres (78.2 percent) of all from its present 165,740 acres ( 81.7 percent), without the project.

It will be necessary to relocate fences to accomodate conveyor belts, haul roads, and ventilation shafts, thereby changing existing patterns of grazing, agriculture, and possibly water supply. If topsoil is introduced during reclamation of tailings pond sites, the resultant area 
will be useful as agricultural land. This land will have a greater agricultural value than before the project because of its new relatively flat character.

\section{Manufacturing}

Prior to the proposed project, DeKalb County leaders had begun an aggressive policy of attracting industry to the county. Capacity use of an existing industrial park in Smithville plus an additional 31 acres have been estimated as the total land area necessary to meet the needs of the county's manufacturing sector without the project. There is no straight line correlation between population and total industrial acreage required, but the growth of the female labor force discussed earlier will attract a corresponding growth in manufacturing. Using a standard scale of 20 employees per gross industrial acre, an additional 60 acres of land will be needed by 1995 (assuming 1200 new industrial employees, using percent of industrial workers in 1970) to accommodate industrial growth due to benefits from economies of scale and population increases.

\section{Commercial}

Commercial (services and retail trade) development is a function of employment and population growth in the county and surrounding areas. Unlike other land uses, as population density and discretionary income increases, the ratio of supportable commercial activity increases. The larger the local market or community, the greater the diversity of commerical activity. To project the commerical acreage needed to satisfy demands in 1995, the Urban Land Institute ratio of 18 employees per acre for mixed rural urban areas was lowered to 13 employees per acre for DeKalb County. Based upon this assumption and the projected growth level, a demand of 105 additional commercial acres will be filled by 1995.

Smithville can be expected to receive the majority of new commercial development, strengthening its position as the major shopping and service area for the county. New commercial acreage is also expected to locate 
along the county's arterial thoroughfares. New convenience centers will likely locate in the smaller towns of Alexandria, Dowelltown-Liberty, and along county roads $56 \mathrm{~N}$ and 141 to serve the resort and rural population.

Public Land

Within the intermediate study area, a large number of outdoor recreation opportunities exist including natural areas, resort parks, day use parks, rustic parks, environmental education areas, scenic trails, reservoirs, and community and day use parks. The projected population growth associated with the project will have sufficient access to abundant regional and community recreational facilities. But, in order to be consistent with the standards of the National Recreation and Parks Association, a ratio of 2.5 acres per 1,000 residents for neighborhood parks and 2.5 acres per 1,000 residents for community parks has been utilized to forecast local (DeKalb) recreational demands. Using these standards, a demand of 67 acres for neighborhood and another 67 acres for community recreation is forecasted to meet peak future population levels associated with the project.

\section{Residential}

By 1993, approximately 5,850 new household units will be needed to accomodate population growth in DeKalb County. Even though there is an ample supply of land suitable for residential development throughout the county and its municipalities, residential densities in the municipalities are expected to double as the expanded population settles into new housing. In 1978, urban residential density averaged 15 dwelling units per acre or 928.8 persons per square mile. Changes in housing distribution and type are projected to increase the combined urban and total county residential density to 1 dwelling unit per acre. While the percentage of mobile homes and multi-family units added to the housing stock is expected to increase, the percentage of single family homes is expected to decrease, in spite of numerical increases. The new high-density residential units will be located in Smithville, Alexandria, and DowelltownLiberty. 
At an assumed average urban residential density of 1 dwelling/acre, approximately 4,720 additional residential acres ( 7.5 square miles) will be required to fulfill the housing needs of the project-related population growth. Undeveloped land will account for over 50 percent of the municipal land area in 1993 (without the project). After developing at least 60 percent (907 acres) of the undeveloped land within these towns to fulfill part of the acreage requirements of the new population, another 3,813 acres ( 6.0 square miles) will be needed for development to meet demand. Therefore, to keep growth within their community boundaries, all four municipalities can be expected annex more land. In existing residential areas there will be a greater density of population as empty lots fill and larger lots are subdivided.

Residential expansion outside the municipalities will occur along the county roads, specifically in the north, northwest, and southwest. Much of this growth will stimulate the conversion of agricultural lands for development purposes.

In 1978, 270 of DeKalb County's 276 square miles were outside the municipalities and predominantly rural. By 19y3, an addicional 18.8 square miles will have been converted to urban use. The annexation of land and county development will decrease rural land areas from 97.8 percent in 1978 to about 90.9 percent in 1993. The major consideration is not shortage of land, but rather how to distribute residential growth to maximize benefits and minimize costs, given the rural lifestyle preferred by a large segment of DeKalb County residents. The county plan calls for controlled dispersion to protect the rural character of the county, which will prevent the new population influx from evenly distributing throughout the county and will insure the growth of Dekalb municipalties.

Table XIII-30 summarizes land use demands with and without the project by the year 1993. The projections shown include unmet 1978 need that eventually will be met. 
TABLE XIII-30. SUMMARY OF LAND USE CHANGES RESULTING FROM PROJECT

\begin{tabular}{lccr}
\hline & $\begin{array}{c}\text { With Project } \\
\text { (acres) }\end{array}$ & $\begin{array}{c}\text { Without Project } \\
\text { (acres) }\end{array}$ & $\begin{array}{c}\text { Total } \\
\text { (acres) }\end{array}$ \\
\hline Residential & 4928 & 447 & 5,375 \\
Commercial & 105 & 20 & 125 \\
Industrial & 67 & 31 & 98 \\
Public & 67 & 3.1 & 70 \\
Project & 6400 & & \\
\hline
\end{tabular}


The estimated land use changes that are expected to take place with the introduction of the project will generally follow the trends anticipated by the existing DeKalb County land use plan. The difference expected is that project-related growth will exacerbate these trends by expanding the urban areas and intensifying rural development along county roads (see Figure XIII-2). Due to the development of an additional 19 square miles of land beyond that covered in the existing land use plan, it will be necessary to formulate another land use plan to reflect the growth policies and direction desired by the new population.

\section{COMMUNITY SERVICES AND PUBLIC FACILITIES}

An assessment of the impacts of a new development on local services, public finance and public facilities is dependent upon the following: 1) assumptions concerning the population growth which would occur with and without the new development; 2) the revenue structures of the public entities being impacted. New public facilities and services are needed (and thus capital outlays are required) only as the total population served by an impacted entity reaches certain "threshold" levels. Although difficult to quantify, the construction and operations of the uranium shale project will definitely impact the county's services and facilities.

Over the short term, taxes would lag behind the need for expansion of facilities and services. Rapid increases in demand will not necessarily concur with their eventual provision. Because of the construction and financing period necessary for completion, over the long term taxes would increase funds available for expansion or improvement.

Greater tax revenues resulting from both the project itself and local economic prosperity will greatly assist DeKalb in providing the extensive public services and facilities needed to satisfy increasing demands made by the growing population. While population increases will stimulate rapid increases in demand for power, water, sewage services, police and fire protection, education, health, recreational and transportation facilities, the added tax revenues will provide the means to initiate 


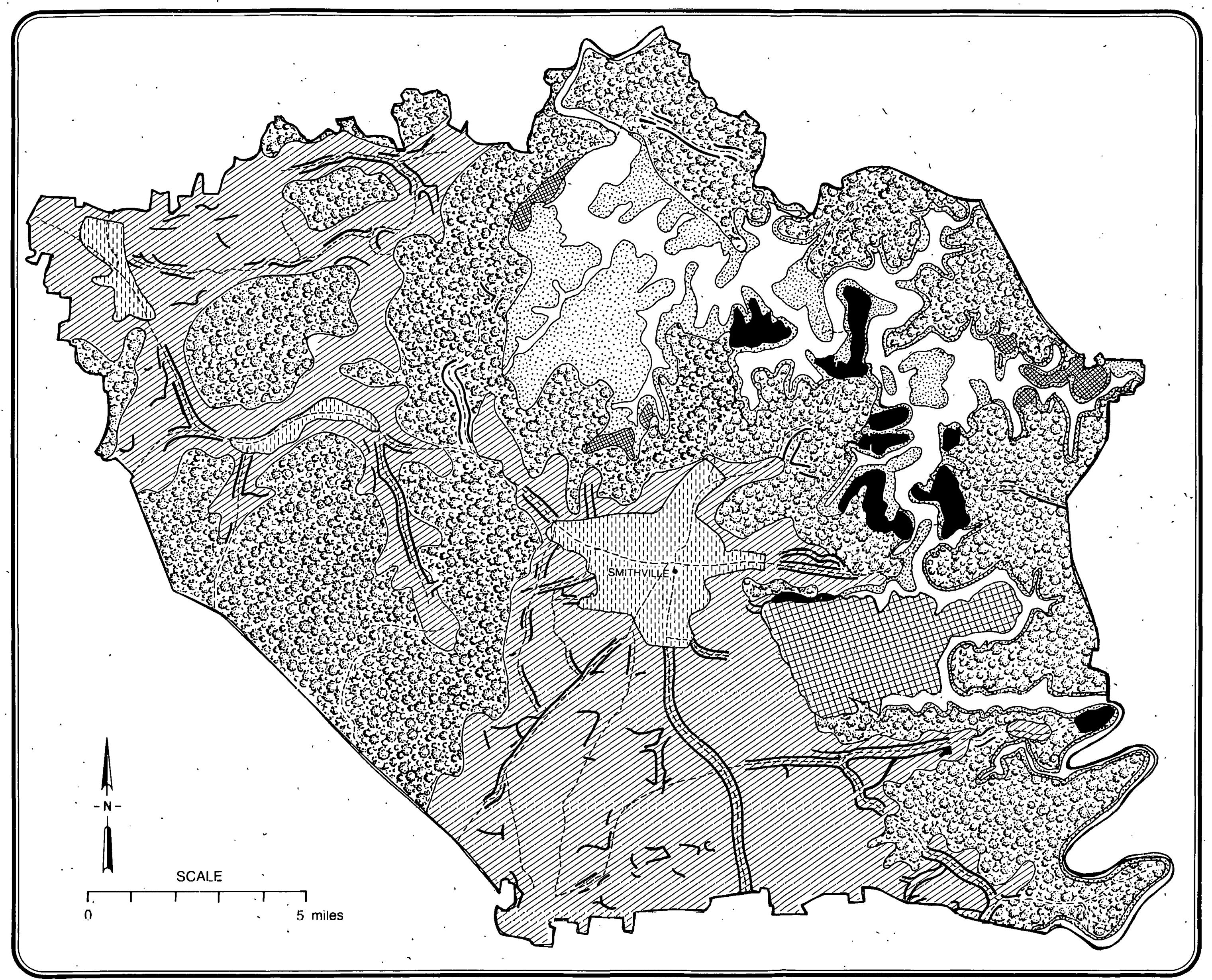

GENERALIZED LAND USE IN DEKALB COUNTY WITH THE PROJECT (Year 1990)

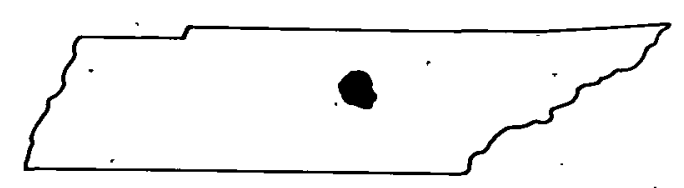

KEY

--. Road

Project Land

$\square$ Water

Forest / Limited Agriculture

Agriculture

Resort/Cabin

Recreation

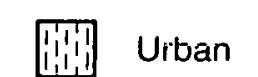

四 Rural Residential

FIGURE.XIII-2 
these changes. In addition to fulfilling the needs of project-associated growth, these abundant new municipal funds will raise the entire county population to a standard level of service.

\section{Infrastructure}

\section{Transportation}

The dominant effect of the proposed project on local transportation will be sharply increased traffic congestion. Employment of 4,000 during the peak construction period, and an average of 3,000 during plant and mining operations will have significant effects on the road network. Traffic will also be generated by indirect workers and their families.

Assuming that most of the population growth and additional employment opportunities will occur in the county's municipalities and a smaller amount will locate along principal roads, it is possible to predict that US 70 through DeKalb will become a major thoroughfare. The traffic flowing to and from the project site and Smithville via this road will result in the need to widen it to four lanes across the county. Most of the other country roads will need to be widened, straightened, or paved to serve the increased demand. All four municipalties will have to extend their street systems to accomodate newly annexed land. Smithville will experience the greatest congestion and need for new roads because. of its proximity to the project site and growing urban character.

Traffic increases, of the magnitude expected with the project, would have a detrimental effect on road maintenance. While taxes paid on the plant facilities, mines, vehicles, and fuel would offset most of the additional rcvenues for highway maintenance, they cannot be expected to defray all such costs.

Due to project demands, more regularly scheduled truck transportation to the county can be expected, along with the potential for the introduction of a rail line into the county. Because there is no railway either presently existing or committed to serving the site area, it must be 
assumed that until one is introduced, all necessary inputs and outputs of the project, other than water and natural gas, would be shipped by truck along existing and improved roadways. Included in these inputs are hundreds of thousands of tons of construction materials and supplies, which would be carried mainly during the off peak traffic hours.

The proximity of the Louisville and Nashville truck system serving adjacent Warner and White counties and connecting with the cities of Nashville and Chattanooga can result in increased activity at the McMinnville railhead as materials and equipment are shipped in during construction. During the operations phase the same location would serve as a transfer point for shipping out byproducts. If McMinnville were to become the focal point, then state road 56 would have to be improved to a standard capable of carrying these materials, equipment, and byproducts.

On the other hand, the existence of the project may make it economical for a rail spur to be extended into Smithville from either the Louisville and Nashville tracks just to the north of DeKalb or more likely (because of flatter terrain) up from their McMinnville or Sparta track.

Air travel into DeKalb County is likely to increase as the population grows and diversifies. Persons using the airport facilities could experience delays due to increased usage. Commerical needs will continue to be filled by the airport in Nashville.

Some disruption of existing secondary, unpaved roads would result from surface excavation for both plant and mine. During the approximately 20-year mining period, several of these ungraded dirt roads would be destroyed. Though no traffic volume figures for these roads are available, it can be assumed that they generally carry only small amounts of local traffic. Much of this local traffic is attributable to residents of homesites which would be displaced by the mining activities. 


\section{Education}

The large influx of construction and operation employees and their families would exert considerable pressure on existing educational facilities in DeKalb, resulting in overcrowding. Crowding could decrease the quality of education. Assuming one third of the population in DeKalb attends school, the average daily enrollment during the construction phase will be about 7,600 increasing to 8,900 during operations. Since projected school capacity in 1988 without the project will only accommodate 3,292 students, new school facilities will be a priority to alleviate this urgent need. In the mean time double sessions will have to be used in the schools.

The three existing elementary schools will be sufficient to handle the needs of the projected growth (Grades 1 through 5). Two middle schools located in Smithville and Liberty will be needed to accomodate the other elementary students. In addition to the existing high school, another high school will be required. Most likely there will be one new high school with the old high school used for a middle school in Smithville.

Over the short term, taxes would lag behind the need for expansion of educational facilities. Over the long term, taxes would increase funds available for expanding and improving local facilities. Assuming 140 square feet per student and a construction cost of $\$ 40$ per square foot, schools for the additional students could require up to $\$ 31,404,800$ in 1993.

\section{Protective Services}

Without the proposed project the County General Plan calls for 10 police officers by 1990 . The new municipal building would provide enough space for this size department. The number of police needed to protect the increased population associated with the existence of the project is expected to rise in proportion to growth. As the crime rate should increase along with the population as the character and small town atmosphere of the county deteriorates to some extent. 
Health Services and Safety

Health care facilities in the area would be directly impacted by the population influx. The tremendous population increase in DeKalb would make it economical for more doctors to locate in the county. Thus fewer people would have to travel to surrounding cities unless in need of specialized care only available at a big city hospital.

Without the proposed project, there will be 100 hospital beds in DeKalb to fulfill the needs of the 1993 population. Assuming the need for one hospital bed for each increment of 200 persons, approximately 63 new beds would have to be added to satisfy demands of the new population.

Initially, at least, existing medical facilities would be overcrowded. It is quite possible that hospital emergency room facilities would be particularly stressed until eventually expanded. As the people find it difficult to obtain a family doctor, they would use the emergency room for routine treatment.

The proposed project could have some positive effects on health care. Increased personal income resulting from the project will allow more routine health care such as medical and dental checkups. Improved access and communications will also enhance area residents' ability to reach public and private health facilities.

Plant and mining operations would have a direct effect on local safety conditions since a necessary corollary of an industrial development is the introduction of new and different safety hazards for people employed in the operation. Increased risks to the health and safety of residents and employees would be associated with many aspects of the project, expecially the increased truck and automobile traffic, mine blasting, handling of the shale and the presence of toxic gases. Hazards are associated with the possible presence of radon, methane, and $\mathrm{H}_{2} \mathrm{SO}_{4}$. The distance of the plant from present and potential populated areas should preclude hazard imposition on persons or property off the plant site. 
The potential adverse direct and indirect effects of relatively low level, but long-term emissions coming from the ventilation stacks, should also be considered. Currently, it is not possible to predict the consequences of releasing such materials into the ecosystem. Emissions from the project are projected to meet applicable federal and state regulations. Nevertheless, accumulations of effluents and possible synergistic reactions may result with some impact to the area.

\section{$\underline{\text { Recreation }}$}

The recreational characertistics of DeKalb County are described in the section on Existing Conditions. The proposed project would not directly affect any of the activities or sites discussed since the recreation/ tourist activities are located in the northeastern portion of the county (where no mining will occur).

The most significant impact on recreational land use will be caused by the influx of people associated with the proposed project. This will result in a significant amount of additional fishing and hunting, as well as a sharp increase in demand for other types of recreation such as parks, swimming, camping and various indoor forms of entertainment. Thus, a need will be created for expansion of recreational facilities such as boat docks, swimming and camping areas. Neighborhood and community recreation areas will be overcrowded and need to develop parallel to demands of population growth. The provision of these facilities will result in the conversion of land.

\section{Utilities}

Each new dwelling unit constructed will require electricity, water and sewer service. The new filtration plant in Smithville, which is capable of pumping 2 million gallons per day, will meet the needs of the 2000 year population, but will have to either be expanded or a new facility built to serve the operational population of 26,760 and a peak employment 
of 4,000 during construction. Water lines will replace wells due to the undermining of much of the county by the project. Expenditures will also have to be made for storm drains.

Water resources for the new population will be available because of the annual rainfall of 60 inches per year and abundant resources in the local aquifer. Project water requirements of 10,000 gallons per minute will not be treated by the local treatment plant. Instead this water will undergo special treatment for minerals, chemicals and other substances and then be reused within the processing operations or eventually discarded into the local ecosystem.

While the present sewer system would have been adequate for DeKalb County without the project, it will not meet the needs of the additional population growth stimulated by the project. Expenditures will be required to expand collection and treatment of sewage during the construction phase. To quickly begin satisfying the growing need, the majority of the new population will live in the municipalities; therefore placing a heavy strain upon the system. It will not be until the late $1980^{\prime}$ 's that the system will be completed. Those families locating in rural parts of the county will use septic tanks.

During the construction phase of the project, portable sanitary facilities will be utilized over the 10 square mile site. The most cost effective method will be used to dispose of these wastes. Two alternatives will be to either: 1) hire an independent contractor to pump the facilities daily and dispose of the sewage at a local treatment plant; 2) use a burial site on the project grounds. Excess construction materials, packaging, and 1,733 cubic yards of paper wastes per year will generage large quantities of solid wastes which will be disposed of at a county landfill site or in whatever manner will fulfill local regulations. The amount of solid waste during construction is expected to be slightly larger than during operations. 
The operations phase will require approximately 50 gallons of water per employee per day ( 160,000 gallons per day) to satisfy the domestic water/waste system on the plant site. This water will be used for showers, sanitary facilities and drinking water. The project will build a small treatment facility to serve these project employee needs rather than hook into the existing Smithville system. Approximately one pound of solid waste generated per employee per day would amount to 1,935 cubic yards of paper wastes per year. The disposal of this waste will follow local regulations. If it is dumped at a. local landfill site, the continued addition of such large amounts of solid waste would require a new landfill site either on the project site or at the county level.

An additional landfill site will be needed to serve the projected and related population and economic growth. The Tennessee Valley Authority can adequately supply all future energy demands directly and indirectly associated with the introduction of the uranium shale project in Dekalb. The project can fulfill its own natural gas requirements by extracting natural gas as a byproduct.

Power requirements for the project alone will be approximately 175,000 kilowatts used on a continuous basis. This wattage would require the construction of a separate power plant on-site to supply the project. This study has assumed that the new Hartsville Nuclear Power Plant will be able to meet other demands. Therefore, it has not included the employment and population figures associated with the building of a new power plant in this analysis.

\section{QUALITY OF LIFE}

The rural character of DeKalb can be described as a link between central Tennessee and Appalachia. The people living there have chosen to do so because of the physical beauty, peace and quiet, clean air, simple life, low crime rate, small town friendliness and low cost of living. The attraction of these qualities can be seen in the types of people that 
have moved into DeKalb over the past 15 years. While the young have been leaving to search for employment, the elderly have been returning to DeKalb for the "quality of life" in which they want to retire. Also, many young and middle aged families have been migrating to DeKalb from the northeast and other urban areas "to get away from the urban life and return to the land."

These groups along with the existing population have strong attachments and emotional commitments to the continuation of DeKalb's quality of life. Personal and business interactions are reflected in the simple life style dictated by the environment. In the past, there have been no serious threats to the rural character of DeKalb, but the deterioration of the economy has lead to a reevaluation of the trade offs involved in expanding or diversifying the economy and population.

In spite of the local commitment to preserve the rural character of DeKalb, the need for new employment opportunities to stimulate the economy and halt population decline is apparent to the majority of the people. This is reflected in the political turnover of the early 1970's when an aggressive but controlled growth policy was initiated. However, another illustration of the attitudes of DeKalb residents towards alteration of their physical environment is the decision to make Center Hill Lake a day use area with pristine shores and limited periphery development.

The introduction of a large scale uranium shale project would produce two conflicting effects on the county. The project will have the positive effect of stimulating the economy and population growth, which in turn can negatively alter the quality of life. Quality of life is the overall character comprised of variables such as air and water quality, noise, cost of living, crime rate, aesthetics, sociocultural factors, community characteristics, provision of services, and pace of life. In other words, quality of life is an overall feeling or attraction which gives an area its character. Therefore, positive increases in quantity will not necessarily produce a positive correlation in the general quality of life because of indirect linkages. Analyzing a few of the individual 
variables of quality of life in the following section, enables one to understand the linkages that will affect local reaction to the project. These linkages will be discussed later in this chapter.

\section{Air Quality}

The primary sources of air pollution' from the mining operation would be diesel equipment emissions, dust and toxic gases. Dust will be generated from vehicular travel, roads, mining, blasting and by wind blowing over disturbed land. Toxic gases escaping through individual ventilation shafts will not be dense enough to cause problems, but overall air quality at the boundaries of the project site cannot be determined at this time.

\section{Noise}

Noise would be greatest during the construction phase of the project but the impact on surrounding residences will be minimal due to the radius of the project site. During both construction and operation phases, the noise impacts will actually be greatest on land adjacent to roads utilized by project vehicles and equipment.

The traffic congestion and average daily traffic from project workers will result in a change in background noise for DeKalb's residences. Noise levels on major roads such as U.S. 70, 56 and 146 and in the municipalities will increase markedly above ambient conditions. People, residing within areas in which the noise levels are higher than preproject ambient noise, will find the noise disturbing to differing degrees. Variables include the activity in which they are engaged and their distance from the plant. Certain artivities will be less affected by increased sound levels than others, although some annoyance will be experienced as a result of the intrusive nature of the sounds. 


\section{Aesthetics}

The overall aesthetic effect will be negative because of both direct and indirect impacts. Direct impacts will include the actual view of the project and the air and noise pollution associated with it. The project will create a visual impact on the local environment beginning during construction. Land cleared for mining portals; plant construction and tailings pond areas will be visible from adjacent land and roads. A dust cloud may be visible above the construction site during the working periods. The intrusive nature of the tailings ponds, which will become larger over the life of the project, will adversely alter the topography and character of the area in which they are located.

A major aesthetic impact of the processing plant will be the relationship of the plant's structures to the land. The processing plant will rise out of a relatively flat farming region where a large building would interupt the landscape and farm land. Its structures are similar to those existing in a refinery: numerous rectangular, cylindrical and tubular interconnected units having relatively low stacks, water and waste treatment facilities, administration buildings, conveyor belts, storage tanks and a personnel building. The function of all but the administration and personnel buildings preclude a design that would be in harmony with the environment.

The mining operations of blasting, excavating and transporting shale can be expected to create localized dust problems and not affect the surrounding county. In certain areas where the shale is close to the surface, strip mining will leave scars that only can be reclaimed over a period of time.

\section{Standard of Living}

Indirect negative impacts on the aesthetics of the area will be due to population growth and uncontrolled development in the county. Unless strict growth controls and planning/zoning regulations are enforced, the 
rural parts of the county will be transformed into semi-suburban environments as a portion of the new population locates out of the municipalties. Even though fulfilling the need for more housing and better services will upgrade the standard of living of the population, the effect of these changes will actually lower the rural population's perception of their quality of life. DeKalb has always offered an alternative to urban living, and most of the residents desire to maintain lower densities so that the rural environment will continue to dominate the mood and appearance of the county.

Problems of providing community services, water, sewage, schools and especially police protection to scattered unplanned clusters of dwellings and businesses are related to uncontrolled development. In addition, if adequate housing is not available, unregulated development of mobile homes will likely occur.

A rapid influx of new residents, especialiy those attracted to small boom situations, tend to establish the foundations for increased crime and delinquency. This situation will be aggravated by the housing shortage, crowding, and the transience of a large percentage of the work force. Along with increased crime, problems of mental illness and alcoholism may increase. Currently these problems are minimal in DeKalb because the population is low and familiar and the atmosphere is of stability and tranquility.

Due to the social problems that parallel the kind of population growth projected for DeKalb County, more police and court activity will be required. Other social services such as mental health counseling also will be necessary to help the population adjust to the rapid changes they will cxperience.

As the population expands, it will diversify enough to cause social interaction problems resulting from prejudicial attitudes. Many of the problems relating to the transition from a rural to a more urban character may be hurled against the minorities that locate in DeKalb County. Even though the influx of blacks: and other minority groups will be small, they will greatly increase the number presently residing in the county. 
In summary, two major impacts will influence the quality of life in DeKalb County: increased population, and a greater per capita and household income. Population increase will change the character of the region into one that is more densely populated, less personal, congested, and faster-paced. Corresponding to increased personal income levels, the population can expect to acquire a better standard of living, even if the cost of living increases. Consequently the population will be able to afford new housing, cars, and other luxury items that demand energy and/or discharge pollutants into the environment. This transition from a rural to an urban character, intensifies alienation of the population from natural environmental systems. 


\section{SECTION XIV \\ REGULATORY CONSIDERATIONS}

The development of a viable uranium-recovery project from the Chattanooga Shale will involve compliance with a vast array of legislation and regulations at the Federal, state, and local levels. It will be necessary both to comply with existing requirements and to plan for the future enactment of significantly more stringent regulations. Since neither the exact nature of the resource.nor the changes in future environmental laws are known at this time, an analysis of the permitting/ licensing/ control process must be based, in part, upon conjecture. However, depending upon the date of project start-up, the degree of environmental regulation can be extrapolated to estimate the future regulatory considerations. The significant present and anticipated environmental regulations which will impact such a project are discussed in this section.

Discussed initially in this section are two pieces of Federal legislation particularly relevant to the contemplated project: 1) the National Environmental Policy Act and its major requirement, the Environmental Impact Statement; 2) the Nuclear Regulatory Commission Radiation Guide 3.8 and its various requirements including the Environmental Report. Subsequently, regulation of various major environmental components (i.e., water, air, rare and endangered species) and disturbance types (i.e., solid waste, noise, surface mining/reclamation) at the Federal, state; and local levels will be discussed.

Federal regulatory authority, related to the contemplated project, is wielded by the following agencies: Environmental Protection Agency (EPA), Council on Environmental Quality (CEQ), Nuclear Regulatory Commission (NRC), U.S. Fish and Wildlife Service, U.S. Army Corps of Engineers, and Mine Enforcement and Safety Administration. Most of the pertinent regulations at the state level in Tennessee are administered by the Tennessee Department of Public Health. 
Much of the existing state legislation and regulations has been passed or promulgated to permit the state agencies' to assume primacy in enforcing compliance with Federal regulations and legislation. The state agencies and programs are currently in a state of flux, due to the lag time involved as state legislators draft, modify, and pass enabling legislation to permit the state agencies to assume primacy and as the agencies draft, propose, and promulgate regulations. The regulatory structure in Tennessee is discussed in some detail in this section, both because it is typical of state programs in the Chattanooga Shale regional area, and because the state is the most likely site for establishment of a uranium recovery operation.

The Tennessee regulatory program is reportedly undergoing extensive review at present to determine its compliance and compatibility with programs in neighboring states. Thus, there could be major changes in the Tennessee regulatory program before the time a Chattanooga Shale project becomes viable.

\section{ENVIRONMENTAL IMPACT STATEMENTS}

One of the most significant recent pieces of Federal legislation is the National Environmental Policy Act (NEPA), passed by Congress in 1969. This act created the Council on Environmental Quality, consisting of three appointed members, within the Executive Office of the President. The CEQ has a stated mission to formulate and recommend national policies to promote the improvement of the quality of the environment.

Congress, in passing NEPA, has stated the Congressional declaration of environmental policy to include the assurance of safe, healthful, productive, and aesthetically and culturally pleasing surroundings; attainment of the widest range of beneficial uses of the environment without degradation, risk to health or safety, or other undesirable and unintended consequences; enhancement of the quality of renewable resources and maximum attainable recycling of depletable resources. Congress has recognized that "Each person should enjoy a healthful environment and that each person has a responsibility to contribute to the preservation 
and enhancement of the environment." The Act provides that all Federal activities should be interpreted and administered in accordance with the policies put forth in NEPA and further provides that all agencies of the Federal government shall:

A. Utilize a systematic, interdisciplinary approach which will insure the integrated use of the natural and social sciences and the environmental design arts in planning and in decisionmaking which may have an impact upon man's environment;

B. Identify and develop methods and procedures, in consultation with the Council on Environmental Quality... which will insure that presently unquantified environmental amenities and values may be given appropriate consideration in decision-making along with economic and technical considerations;

C. Include in every recommendation or report on proposals for legislation and other major Federal actions significantly affecting the quality of the human environment, a detailed statement by the responsible official on--

(i) the environmental impact of the proposed action;

(ii) any adverse environmental effects which cannot be avoided should the proposal be implemented;

(ii) alternatives to the proposed action;

(iv) the relationship between local short-term uses of man's environment and the maintenance and enhancement of long-term productivity; and

(v) any irreversible and irretrievable commitments of resources which would be involved in the proposed action should it be implemented.

D. Study, develop, and describe appropriate alternatives to recommended courses of action in any proposal which involves unresolved conflicts concerning alternative uses of available resources;

E. Recognizc the worldwide and long-range character of environmental problems and, where consistent with the foreign policy of the United States, lend appropriate support to initiatives, resolutions, and programs designed to maximize international cooperation and anticipating and preventing a decline in the quality of mankind's world environment;

F. Make available to states, counties, municipalities, institutions, and individuals, advice and information useful in restoring, maintaining, and enhancing the quality of the environment; 


\section{THIS PAGE WAS INTENTIONALLY LEFT BLANK}




\section{NUCLEAR REGULATORY COMMISSION}

The Atomic Energy Act of 1954 placed sole responsibility for the manufacture, control, and disposition of "source, by-product, and special nuclear materials" upon the Atomic Energy Commission, now the Nuclear Regulatory Commission (NRC). Specifically, within the Chattanooga Shale uranium recovery circuit, the responsibility for milling of the uranium to the production of yellow cake (uranium oxide) is specified to be the responsibility of the NRC. The NRC has, in some cases, delegated responsibility for this authority to "Agreement States," those states which have developed a program satisfactory to the NRC for the licensing of nuclear handling facilities. Tennessee is such an Agreement State. An extensive body of data and regulations have been developed by the NRC and are documented in 10 CFR 20. This includes limits for air and water for a number of radionuclides in the control zone, in an area of worker exposure, and in an area of general public exposure.

The NRC requires that all applicants for a uranium milling license submit a detailed Environmental Report as specified in the NRC Radiation Guide 3.8. At present, there is no firm requirement that mill applicants within Agreement States develop an Environmental Report in the same nature as for non-Agreement State applicants. However, recent litigation involving the Natural Resources Defense Council has exerted pressure upon the NRC to require Environmental Reports for Agreement State applicants as well. It would appear reasonable to assume that any mill involved in recovery of uranium from the Chattanooga Shale will be required to submit the extensive Environmental Report as required by Radiation Guide 3.8. Other NRC radiation guidelines govern the method of construction of tailings ponds, the discharge of radiation material to the environment, and methods of plant operation. 
The following performance objectives have been developed for tailings management by the NRC:

\section{Siting and Design}

1. Locate the tailings isolation area remote from people such that population exposures would be reduced to the maximum extent reasonably achievable.

2. Locate the tailings isolation area such that disruption and dispersion by natural forces is eliminated or reduced to the maximum extent reasonably achievable.

3. Design the isolation area such that seepage of toxic materials into the groundwater system would be eliminated or reduced to the maximum extent reasonably achievable.

\section{During Operations}

4. Eliminate the blowing of tailings to unrestricted areas during normal operating conditions.

\section{Post Reclamation}

5. Reduce direct gamma radiation from the impoundment area to essentially background.

6. Reduce the radon emanation rate from the impoundment area to about twice the emanation rate in the surrounding environs.

7. Eliminate the need for an on-going monitoring and maintcnance program following successful reclamation.

8. Provide surety arrangements to assure that sufficient funds are available to complete the full reclamation plan.

There is some apparent overlap between NRC and EPA responsibilities in the areas of uranium milling. In view of this overlap, both agencies have exercised control. The recent Supreme Court decision in the case of Colorado Public Information Group vs. Train decided that NRC had sole responsibility for special source and by-product material, but specifically stated that radium was not beyond the purview of the Environmental Protection Agency. Thus, this is one radioisotope which remains under dual control by NRC and EPA.

Another area of overlap is that the Environmental Protection Agency specifies standards for radiation exposure to the general population 
outside of control zones; while the Nuclear Regulatory Commission provides enforcement activity to assure that these radiation standards are met. NRC appears to be moving actively into areas of control of pollutants other than radioisotopes. Thus, the NRC permit reasonably could be expected to specify a number of other parameters and also address the area of plant operation.

\section{WATER}

Discussed in this segment, by promulgating agency, are the various Federal, state, and local regulations addressing the maintenance of satisfactory water quality that may be expected to exert influence upon the contemplated project.

\section{FEDERAL REQUIREMENTS}

The two major Federal agencies promulgating water-related regulations which will affect establisment and operating of the project are the Environmental Protection Agency and the U.S. Army Corps of Engineers.

\section{Environmental Protection Agency}

The Environmental Protection Agency was created by Executive Order in 1970, combining previously scattered regulatory authority from a number of different regulatory bodies. The actions of the EPA will influence a Chattanooga uranium recovery project as it relates to water, air, solid waste, noise, and radiation protection. Each of these media is discussed in this section where appropriate.

Discharge of water pollutants into navigable waters of the United States is controlled under the Water Pollution Control Act Amendments of 1972 (PL 92-500). The basic thrust of this Act is to improve water quality by source regulation of discharge of pollutants. Discharges of pollutants are controlled by the issuance of National Pollutant Discharge Elimination System (NPDES) permits, either by the EPA or by licensing states, which administer an NPDES program under the general overview of the EPA. Permits are required for all point source discharges. 
The term "point source" is defined as "any discernible, confined, and discrete conveyance, including but not limited to any pipe, ditch, channel, tunnel, conduit, well, discrete fissure, container, rolling stock, concentrated animal feeding operation, or any other floating craft, from which pollutants are or may be discharged." The term "navigable waters" is so broadly defined that any discharge from a point source which enters surface water may be presumed to be covered by the Act: The Act will therefore exercise control over the operating of a Chattanooga Shale mining operation in at least two areas.

The quality of mine water discharged to any surface stream will be regulated under the issuance of a NPDES permit. The Environmental Protection Agency is required by PL 92-500 to develop guidelines for best practicable control technology presently available (BPT) to be applied to all discharges by July 1, 1983. Best available technology (BAT) requirements àre also to be imposed for all new sources, which would include mine water discharged from a Chattanooga Shale recovery project. Regulations defining BPT and BAT were published in the November 6 , 1975 issue of the Federal Registex. Those requirements governing the mining of uranium, radium, and vanadium ores were subsequently withdrawn, due to problems of the data base used in development of the regulations. To date, they have not been reissued, either for BPT or BAT levels. However; such requirements are to be published in the near future and will definitely be in force and have control over discharge from a Chattanooga Shale mining venture.

It is possible to speculate on the general nature of the requirements as they will be issued. The requirements are almost certain to recognize the necessity for discharge of mine water, but will impose treatment requirements upon the effluent. These will probably take the form of limitations upon suspended solids, various metals, and certain radionuclide parameters, most probably either radium 226, or radium 226 and 228. The allowable radium levels will probably be approximately 3 picocuries per liter. In addition, a total radium limitation (dissolved and suspended) might be specified. 
Potential effluent discharges from a uranium processing plant receiving Chattanooga Shale similarly will come under the requirements of the effluent guidelines. for uranium mills. As in the case of uranium mine discharges, no guidelines are currently applicable to operations of the type contemplated. However, it is probable that the BAT requirements, when published, will take the form of the prohibition of discharge of pollutants to navigable waters. Thus, any effluent from the milling operation will likely have to be recycled or otherwise disposed, with no discharge to surface waters.

The Act provides that application for an NPDES permit must be filed at least 180 days prior to the initiation of operations. The NPDES issuance procedure provides specific comment periods for several different segments of the populace. However, the Act also provides that, in non-permitting state areas, the state must be given a "reasonable period" to certify that a proposed action will not result in violation of state stream standards. This "reasonable period" can be as long as 1 year. Thus, application for an NPDES permit should be filed at least 1.5 years prior to the anticipated date of operation.

The Water Pollution Control Amendments require that the various states adopt water-quality standards for intrastate and interstate streams. The standards, when submittted to and approved by the EPA, then become applicable Federal standards. The Act further requires that effluents having a quality equal to or better than BPT, when discharged to a stream of high quality, may further be required to be treated to levels as good as, or better than, BAT, or discharge may be totally prohibited, where the discharge would result in a stream standard violation. The contemplated Chattanooga Shale mining operations will be required to meet applicable water quality standards within the mining area. Tennessee standards for the potentially affected streams are discussed later in this section.

The discharge of "oil and hazardous substances" is controlled under Section 311 of PL 92-500. The EPA has promulgated regulations requiring 
the development of a "Spill Prevention Control and Countermeasures" (SPCC) Plan, for facilities storing more than specified amounts of oil and hydrocarbons.

Because of recent spills of hazardous substances, pressure is being exerted to expand the SPCC requirements to cover any storage of a "hazardous substance," which probably would include material associated with the Chattanooga Shale project. For example, the draft criteria would consider anything with a radium-226 concentration of 3 picocuries per gram as hazardous. At present, a SPCC plan would be required for hydrocarbon storage at a recovery facility associated with the proposed project.

Section 208 provides for "Areawide Waste Treatment Management." Under terms of this section, the governors of the various states may identify areas of urban-industrial concentration or other factors which have significant water quality control problems. After such designation, the Administrator of the EPA is authorized to make grants to regional planning agencies to develop plans for control of areawide pollution and the development of a continuing areawide waste treatment management planning process. These plans are to develop requirements for the establishment of a regulatory program to implement the plans as developed and to assure that all industrial or commercial waste discharged into any such treatment plant meet applicable pretreatment requirements.

Responding to environmentalists, the EPA has determined that nonurban areas should be covered by statewide 208 plans. Such plans covering the proposed mining areas are to be published by November 1978 .

Recent litigation (Colorado Public Interest Group vs. Train) affects the EPA control potentially exercises over possible discharges from a Chattanooga Shale facility. This decision was rendered by the Supreme Court in a suit by an environmental group seeking to require the EPA to include radioactive parameters in the NPDES permit for a discharge from a nuclear power facility. The Supreme Court ruled that the authority to license radioactive discharges is vested within the Nuclear Regulatory Commission. 
However, the wording of the decision indicates that the EPA does have responsibility for governing non-nuclear parameters associated with radiation discharges and further provides that the EPA can limit the natural radioactivity parameters (specifically radium 226 ).

The Environmental Protection Agency is charged, under the Safe Drinking Water Act of 1973, with providing for the national health via the protection of public drinking water supply systems. As a result of the Act, the Environmental Protection Agency has established National Primary Drinking Water Standards, which include a limit of 5 picocuries per liter for radium 226 plus 228 . Public drinking water supply systems are defined as including more than fifteen service connections, or use by a least twenty-five individuals for 60 days out of the year. Thus, any mine-mill operation involving uranium recovery from the Chattanooga Shale would. be considered to include the operation of a public water-supply system. Such systems must be periodically sampled, and users notified if the system does not meet the EPA drinking water standards.

The Safe Drinking Water Act further attempts to protect underground water by controlling the practice of underground injection of wastes. The Act provides that the EPA shall develop regulations to govern the practice of subsurface waste injection, and establishes a permit program for such injection, similar to the NPDES system. This permit program is to be administered by the states, if desired, or by EPA if no state program is established.

The EPA has proposed regulations to establish minimum criteria for underground injection control programs. As originally proposed, the program would govern the practice of well injection through drilled, bored; or driven wells and through dug wells the depths of which are greater than the maximum horizontal dimension. Permits would be required for all underground injections which fall under this definition of a well. As originally proposed, the regulations would not govern seepage from ponds. However, it is very likely that such control will be developed in the future either through the Underground Injection Control (UIC) program or under provisions of the Resource Conservation 
and Recovery Act (discussed later in this section). Thus, a uranium recovery project from the Chattanooga Shale can reasonably be expected to fall under the area of groundwater pollution control from seepage from the various ponds and waste impoundments associated with the facility. Waste storage ponds will probably require liners and approval to construct.

\section{U.S. Army Corps of Engineers}

Section 404 of the Water Pollution Control Act Amendments of 1972 (PL 92-500) authorizes the Secretary of the Army, through the Corps of Engineers, to issue permits for the discharge of dredged or fill material into a navigable water of the United States at approved discharge sites.

Implementation of Section 404 has generated significant controversy, as a result of the broad definition of navigable waters adopted by the Corps of Engineers. The term "navigable waters" is defined to include not only coastal waters, rivers, lakes, streams, and artificial water bodies that have been used in the past or are now used (or are susceptible to use) as a means to transport interstate commerce, but also all interstate waters and tributaries of navigable waters up to their headwaters and landward of their ordinary high water marks. This is taken to mean the point on the stream above which the flow is normally less than 5 cubic feet per second. As a result of this broad definition, activities conducted throughout the envisioned Chattanooga Shale uranium recovery site are subject to jurisdiction of the Corps of Engineers under Section 404 if such activities involve dredging or filling in any stream with a flow of greater than 5 cubic feet per second.

Dredged material is defined as material that is excavated or dredged from navigable waters, but excluding material resulting from normal farming and ranching activities. A discharge permit is required for the addition of dredged material into navigable waters in excess of 1 cubic yard when used in a single operation. Fill material is any pollutant used to create fill in the traditional sense of replacing an aquatic area with dry land or changing the bottom elevation of a water body for any purpose. Thus, any dredging of waterways within the project site 
area, or filling of potential waterways, including the construction of road crossings of streams, will require dredge and fill permits to be issued by the Army Corps of Engineers under Section 404. Any alteration of a natural stream channel, construction of diversion dams, construction of bulkheads, and discharge of tailings likewise will require a Section 404 permit.

Because the activities enumerated above are so vast; the Corps of Engineers has chosen to implement the permit procedure in three phases. Discharges into coastal waters or into inland navigable waters, navigable in the traditional sense, and discharges into fresh wetlands require permits as of July 25, 1975. Discharges into primary tributaries of navigable waters, and wetlands adjacent to primary tributaries and lakes are covered as of October 1, 1976. Discharges into all other "navigable waters" including the headwaters of tributaries are governed as of July 1, 1977 .

A crucial requirement of the permit review process under Section 404 is the requirement that certification be given by the state or appropriate interstate water pollution control agency prior to the issuance of a permit to the effect that any discharge will comply with the applicable effluent limitations and water quality standards.

The permit application is reviewed also by the Environmental Protection. Agency. The EPA has the authority to prohibit the discharge into a specific site if it determines that the proposed discharge will have an unacceptable adverse effect upon municipal water supplies, fishing areas, wildlife, or recreational areas. Time involved in obtaining such a permit is usually approximately 180 days.

\section{STATE REQUTREMENTS}

Water-related regulations at the state level which will impact a Chattanooga Shale uranium recovery operation are administered by divisions of the Tennessee Department of Public Health. 
The NPDES discharge permit program authority was granted to the Tennessee Department of Public Health, Division of Water Quality Control, by the EPA in December 1977. At present, the state permit program is in the early stages of organization, but will be fully operable by the time any Chattanooga Shale recovery project is initiated. Permit program agency personnel recognize that no guidelines currently exist for the NPDES licensing of a facility such as that anticipated for mining and processing Chattanooga Shale. They would tend to follow the approach of combining guidelines from similar industries, most likely the guidelines from acid producing open pit mines and uranium mines.

At present, the Tennessee Department of Public Health does permit mining operations to extend through surface watercourses. However, when a major coal mining company proposed to initiate a program of "area mining" in the Cumberland Plateau in Sequatchie and Bledsoe Counties, Tennessee, the Division of Water Quality Control concluded that the modification of a wooded plateau landscape into a rolling grassland physiography would irreparably alter the character of the coldwater Plateau streams. They concluded that area mining techniques were not suitable to Cumberland Plateau topography and opposed the project.

A Chattanooga Shale uranium recovery project should be designed to control run-off associated with 25-year/24-hour precipitation events. Milling operations should be designed for zero discharge of process water, with the exception of rainfall associated with very high precipitation event frequencies. The EPA effluent guidelines for phosphate fertilizer production are a reasonable source to consider for development of milling guidelines for the Chattanooga Shale project.

Water quality criteria for Tennessee streams were adopted in November 1972 by the Tennessee Water Quality Control Board. In general, streams in the Chattanooga Shale regional area are classified for fish and aquatic life propagation, recreation, irrigation, and livestock and wildlife watering uses. Certain stream segments are also classified for domestic 
water supply. These uses carry attendant quality requirements on parameters such as dissolved oxygen, $\mathrm{pH}$, total dissolved solids, etc. Effluents will have to be treated to prevent violation of the various criteria.

\section{$\underline{\text { AIR }}$}

The Chattanooga Shale mining and processing project will be affected by a complex series of Federal, state and local air quality regulations and guidelines. At present, most of the air quality regulatory power in the study area rests with Federal and state control agencies as opposed to local jurisdictions. Nashville and Chattanooga have their own air pollution control districts, but the rest of the area is under state control or covered by Federal agencies. Since air quality rules are derived from Federal and state legislation, they are not as fragmented as they might be if they were governed by local jurisdiction.

Although air pollution has been recognized as a problem for a number of years, only in the last decade has the sudden proliferation of agencies and laws had a serious impact upon new and existing pollution sources. The expanded awareness of the quality of life has brought about a number of environmental safeguard requirements that have greatly increased the number of plans, permits, assessments, licenses; etc., for development or modifications of potential pollution sources.

\section{FEDERAL REQUIREMENTS}

The principal Federal agencies vested with air quality regulatory authority are the Environmental Protection Agency and the Nuclear Regulatory Commiccion.

\section{Environmental Protection Agency}

The Environmental Protection Agency controls sources of air pollution under provisions of the Clean Air Act, as extensively amended December 31 , 1970 by PL 91-604, and as recently amended by Congress. Many states 
have, in turn, adopted extensive air pollution control legislation under the "state delegation" provisions of the Federal act. The four aspects of the Clean Air Act having the most significant impact upon the contemplated Chattanooga Shale mining operations are the provisions relating to:

a) implementation plans for national primary and secondary ambient air quality standards; b) standards of performance for new stationary sources; c) emission standards for hazardous air pollutants; d) the prevention of significant deterioration concept.

\section{Ambient Air Quality Standards (AAQS)}

The program for adopting implementation plans for national primary and secondary ambient air quality standards has several stages. The first is the designation of Air Quality Control Regions in interstate or major intrastate areas for the attainment and maintenance of ambient air quality standards. For this purpose, the Administrator of the EPA publishes a list which includes each air pollutant that has an adverse effect upon public health or welfare. To date, these pollutants include $\mathrm{SO}_{2}$ and total suspended particulates (TSP). The Federal Register of December 2, 1977 indicates that proposed addition of other pollutants including hydrocarbons, carbon monoxide, $\mathrm{NO}_{2}$, and lead are expected in October of 1978. Listing of currently unregulated pollutants such as arsenic and cadmium, is planned for August of 1978, and listing is planned for radioactive pollutants in August of 1979. Thus, it is reasonable to expect that a number of National Primary Ambient Air Quality Standards will be operational by the time of implementation of a Chattanooga Shale uranium recovery project.

National Primary Air Quality Standards and National Secondary Air Quality Standards are established by the EPA for each of the various air pollutants listed under the air quality criteria. Primary standards are established on the basis of the maximum permissible concentration necessary to protect the public health, while secondary air quality standards establish a maximum level necessary to protect public welfare, including such considerations as vegetation damage, wildlife, odors, and other factors which affect the general quality of life. 
After the various standards are set, the states are responsible for determination of how the national air pollution objectives are to be reached. Each state must adopt and submit to the EPA a plan which provides for implementation, maintenance, and enforcement of primary and secondary standards in each air pollution control region. If a state implementation plan is approved by the EPA, the state is given responsibility for enforcement to assure that the air quality standard will be attained and maintained. Such implementation plans may require installation of extensive air pollution control equipment at existing sources and provide for the standard of performance for new stationary sources.

Many confrontations between the EPA and industry or government have arisen over strategies to achieve and maintain ambient air quality standards. The EPA's rejection of many of the elements of various State Implementation Plans (SIP's) and substitute EPA strategies have led to several court tests which have upheld EPA regulations with only a few exceptions. Unfortunately, the confrontal style and constant adversary position of EPA have led to a strong polarization between industry and the agency. The erosion of popular support of air pollution control, generated in part by economic pressures, will make air quality a political issue in the future. Progress in improving the atmospheric environment will be slower since many pollution sources, both mobile and stationary, are now under regulated control schedules. Major new industries have to be designed with New Source Performance Standards and their impacts analyzed under a unified program of New Source Review, as discussed next.

\section{New Source Performance Standards (NSPS)}

A new source is "any stationary source, building, structure, facility, or installation which emits or may emit an air pollutant, the construction or modification of which is commenced after the publication of regulations or proposed regulations establishing an emission standard whch will be applicable to such source." The Chattanooga Shale operation would be a 
new source under this definition. The Administrator of the EPA is required to publish a list of categories of stationary sources and to publish regulations establishing Federal standards of performance for new sources within each such category. The Act provides that states may implement and enforce standards of performance for new sources if the state develops a plan found to be adequate by the Administrator of EPA. The EPA still retains authority to enforce any applicable standard of performance.

The Clean Air Act itself does not specifically require that permits be obtained for new sources. The owner or operator of such a source has the legal responsibility for compliance with an applicable standard and must comply with regulations that contain extensive requirements relating to reporting and data gathering. The permit for a new source, however, is generally required under applicable state law.

If the affected facility is located in a state not having an approved New Source Review (NSR) program, an owner or operator must notify the EPA of the anticipated start-up date of such facility not more than 60 days or less than 30 days prior to start-up. The EPA must also be notified of the actual start-up within 15 days after such date. Records must be kept concerning emissions and effectiveness of emission control equipment. Within 60 days after the maximum production rate is achieved, but not more than 180 days after initial start-up, the facility must be sampled, with performance test data results sent to EPA. Conformance with the NSPS is determined by application of performance tests as set forth in the regulations promulgated by EPA.

Allowable emission limitations for refinery operations (including the sulfuric acid plant) and for the subsequent storage of the synthetic oil or synthetic natural gas have been established and will apply to the project. NSPS regulations further require a "technological system of continuous emission reduction" that assures that the proper technology for emission limitations is both selected and then maintained for the life of the project. Until the shale oil resource is defined, the hydroretorting process completely understood for a project of this size, 
and the project design finalized, NSPS can be discussed only in general terms as they relate to the project: Assuredly, the refinery operations will have a clear-cut set of emission standards that provide a good upper limit on the possible emissions from the refinery operations.

\section{Hazardous Air Pollutants}

The Clean Air Act also provides the EPA. with authority to set national standards for "hazardous air pollutants." These are air pollutants to which no ambient air quality standards are applicable and which the EPA Administrator judges may cause or contribute to an increase in mortality or an increase in serious, irreversible, or incapacitationg illness.. The Administrator is directed to prescribe emission standards for each such hazardous air pollutant. These standards establish a level that provides an ample margin of safety to protect the public health. After the effective date of such an emissions standard no person may construct any new source or modify any existing source that will emit a hazardous air pollutant in violation of the standards. Emission standards have been established for asbestos, beryllium, and mercury. Chattanooga Shale processing methods involving the use of heat and drying and possible emission of asbestos or mercury will need to be stringently controlled.

\section{Prevention of Significant Deterioration (PSD)}

One of the most significant aspects of the Clean Air Act has resulted in response to judicial interpretation of the Act. The decision was rendered that the Environmental Protection Agency was required to promulgate regulations providing for the classification of all the United States, except areas that exceeded National Ambient Air Quality Standards, for sulfur dioxide or TSP into areas based upon degrees of air quality deterioration which would be permitted within the region. The resulting effort, directed toward halting further degradation of a1r quality in polluted regions and protecting designated areas from future pollution, has resulted in the PSD concept. The purposes of PSD are as follows:

- To protect the public health and welfare from pollutant exposure, notwithstanding attainment and maintenance of AAQS; 
- To protect and enhance national parks, wilderness areas, monuments, seashores, and other important visual areas;

- To insure that economic growth and clean air are compatible goals;

- To assure that emissions from one state will not interfere with the SIP in another state;

- To provide adequate review and public participation in the decisionmaking process to allow increased air pollution in a given area.

PSD requires that areas be designated as Class I, II, or III corresponding to minimum, nominal, and maximum allowable additional emissions of particulate matter and sulfur dioxide. In Class I areas, practically any change in air quality is considered significant deterioration. In Class II areas, deterioration normally accompanying a moderate, wellcontrolled growth would be considered insignificant. In Class III areas, deterioration up to the National Air Quality Standards is considered insignificant. Initially, all areas of the country were designated as Class II areas. The respective states, however, are permitted to reclassify any area to accommodate the social, economic, and environmental needs and desires of the public. All national parks have immediately been classified as Class I areas. Therefore, any operation in the vicinity of a national park reasonably can be expected to result in "significant deterioration" of the air quality within the area.

New sources of air pollution must be reviewed prior to construction to determine whether anticipated emissions of particulate matter and sulfur dioxide from these sources would cause significant deterioration. No owner or operator is permitted to commence construction or modification unless the effect, in conjunction with effects of growth and reduction in emissions in other sources in the area, will not violate the air quality increments applicable in the areas where the source will be located, nor the air quality increments applicable in other affected areas. In addition, a new or modified source must meet an emissions limit which represents that level of emission reduction which would be achieved by the application of Best Available Control Technology for particulate matter and sulfur dioxide. Specific regulations have been adopted in this area for phosphate rock processing plants. Because of 
the high phosphate content present in certain portions of the Chattanooga Shale, it is reasonable to assume that the plant should meet those standards for phosphate rock processing.

There are currently no mandatory Class I areas in the study area. The relatively "clean" areas of much of the rural environments in Kentucky, Tennessee, and Alabama will allow for growth by polluting industries as long as they remain under the incremental allowable ambient air quality increase and apply the best available control technology to the emission process.

In order to establish the current ambient air quality of the project area, a baseline concentration profile of all criteria pollutants will probably be required. Ambient air monitoring for 1 year is generally taken as sufficient to satisfy this requirement. The baseline concentration, upon which a PSD pollution increment is allowed, is defined as the concentration which exists at the time of the first application for a permit subject to PSD limits.

Further guidance on PSD, including increments for all criteria pollutants (not just TSP and $\mathrm{SO}_{2}$ ), will be published by the EPA in late 1978. A complete summary of progress in implementing the PSD concept will be available in 1979. Since the project likely will not reach the permit stage for a number of years, some changes in the actual PSD implementation procedures may nrsur, but the PSD philosophy is apparently here to stay.

Although EPA originally classified all areas as Class II except for certain mandatory Class I areas, states have the option to reclassify areas into Class $I$ and Class III. In terms of allowable pollutant increase, PSD will allow an increase of up to 50 percent of the ambient air quality standard in specified regions where major industrial growth is to be encouraged. As noted above, additional PSD increments for other pollutant species will soon be issued.

Although the Chattanooga Shale study region is generally an attainment area (AAQS are not violated) for $\mathrm{TSP}$ and $\mathrm{SO}_{2}$ except in a few heavily 
populated or industrialized areas, baseline studies may show that standards for photochemical oxidant are being violated, such that very stringent hydrocarbon emission standards may apply to the shale refinery operations. Until both the standards are developed, baseline studies are completed, and a project description finalized, it can be said only that the project will meet the incremental deterioration rules through emission controls as necessary, but the final extent of those controls has not been determined yet.

\section{Emission Offsets (Trade-Offs) in Non-attainment Areas}

If the project site is located in an area designated as a non-attainment area due to pollutant emissions generated in the vicinity of the project, the provisions of the EPA interpretive regulation published in 41 Federal Register 55524-30, December 21, 1976, will apply. Under these provisions, the project will be allowed to proceed without a special variance only if it causes a reduction of current, existing emissions equal to or greater than the proposed project for each non-attainment pollutant species. Early applications of the trade-off philosophy have resulted in minimum required reductions of pollutants by factors of one to over seven times the estimated project emissions. Much of the study area does not appear to violate most air quality standards since few major sources are present in the more rural environs, therefore the elements of the emission off-set rulings should not affect project planning.

\section{Transportation Planning}

Although the EPA does not have the authority to impose a transportation control plan, it is charged with providing information to all Federal, state and local air pollution control agencies regarding processes, procedures, and methods to control all pollutant species. EPA responsibility includes the following items possibly related to the contemplated project:

- Motor vehicle inspection and maintenance programs 
- Vapor emissions control from fuel transfer and storage

- Public transit programs

- Areawide carpool programs

- Long-range transit improvements

- Parking control

- Employer participation in carpooling, vanpooling, mass transit, bicycling and walking

- Bicycle storage, bike lanes, protection of bicyclists

- Staggered work hours

- Road user charges, tolls, and differential rates for single occupancy vehicles

- Traffic flow improvement programs

- Clean fuel conversions of fleet vehicles

- Retrofit programs for non-light duty vehicles

EPA is to weigh the effectiveness and the environmental, energy, and economic impact of each proposed process, procedure, and method. Considering the tremendous increase in transportation-related emissions anticipated from the shale mining and processing work force, such future EPA strategies will definitely affect project transportation planning.

\section{Nuclear Regulatory Commission}

The atmospheric release of radioactive material, while not strictly an air quality problem, involves the use of on-site meteorological data for dispersion calculations similar to those required for any non-radioactive emission. Determination of the diffusion factor $(X / Q)$ for slightly-elevated, controlled releases has been performed in Section XII. Identical calculations using more precise site data will be required by the Nuclear Regulatory Commission if the project is to be implemented. NRC's impact assessment methodology, data requirements, and review procedures for atmospheric releases from uranium processing facilities to date have been as stringent as for any nuclear generating station or other nuclear materials handling operations. 
Acquisition of baseline meteorological inputs for dispersion estimates is usually accomplished through an on-site meteorological program consistent with the guidelines of NRC Regulatory Guide 1.23. Although off-site data such as the Smithville, Tennessee summaries can be used in the preliminary environmental report process, the NRC will require, for the EIS, installation of a meteorological tower for recording measurements of wind, temperature, and perhaps humidity at several levels on the tower. One year of on-site data is required with two years recommended. Data systems must be designed to capture 90 percent of the readings .

Methodologies for making acceptable diffusion $(X / Q)$ estimates are contained in NRC Regulatory Guide 1.4. Further clarification of the applicability of the dispersion parameters may be obtained from the NRC Licensing Staff, Site Analysis Branch, Directorate of Licensing. Recent additional requirements for introducing realism into the dispersion estimates requires that regional estimates be carried out to $80 \mathrm{~km}$ as detailed in NRC Regulatory Guide 1.111. In areas of potential Chattanooga Shale resource development with relatively even terrain, such estimates probably can be made easily and somewhat accurately. In areas of complex terrain such as those along the Cumberland Plateau or along the rivers, or for complex atmospheric physical and chemical processes, such estimates are difficult to obtain except through highly simplified correction factors. Although some of the specific aspects of the NRC requirements may change, the NRC practice of very specifically outlining the precise set of impact calculations makes it easier to carry out the environmental assessment process.

EPA has aimed for similar specifity in two recent guidelines entitled:

- Guidelines for Air Quality Maintenance Planning and Analysis, Volume 10 (Revised): Procedures for Evaluating Air Quality Impact of New Stationary Sources, EPA-450/4-77-001, OAQPS No. 1.2-029R, 1977;

- Interim Guideline on Air Quality Models, OAQPS 1.2-080, 1977. 
Since the NRC has previously insisted upon a high degree of conservatism (over-prediction), while much of the air pollution modeling community has concentrated upon physical realism, some diversity in approach and philosophy naturally is to be anticipated. Both agencies, however, stress a Gaussian diffusion approach supplemented by more detailed dispersion prescriptions, if necessary, and one might expect that impact assessment guidelines will be delineated quite clearly when a formal EIS for Chattanooga Shale development is prepared.

\section{STATE REQUIREMENTS}

Air quality regulations are enforced at the state level by the Tennessee Division of Air Pollution Control which essentially acts as a vehicle for the EPA and NRC. The Division of Air Pollution Control is a division of the State Bureau of Environmental Health Services with the Tennessee Department of Public Health. Its legislative authority is derived from the Tennessee Air Quality Act (Tennessee Code Annotated (TCA), Section 53-3408, et seq.) passed in 1967 as subsequently amended. The rules established by the division first became effective in 1969 and have since been amended considerably. Present rules are detailed in Chapters 1200-3-1 through -17 under the statutory authority of TCA, Section 53-3412 of the Tennessee Air Quality Act with the latest rules amended effective February 9, 1977. Tennessee is very conscious of the cost/ benefit relationship between clean air and industrial economics. The underlying premise of the state rules is spelled out in the "General Provisions" of Chapter 1200-3-1 of the Air Pollution Control Regulations, viz. ,

(2) These regulations are based upon the premise that the basic and foremost function of the air is to sustain life and that air in its purest state is best suited for this need. It is intended that these regulations assist in maintaining an equitable balance between benefits of clean air and the economic cost of achieving clean air. More specifically, it is intended that these regulations define ambient air quality standards to be achieved and maintained and to provide for an orderly and equitable regulation of air quality by limiting emissions of air contaminate. (1200-3-1.01 GENERAL RUIES) 
Under the provisions of the Tennessee Air Quality Act, an Air Pollution Control Board consisting of twelve members experienced in air pollution control, abatement, management, health effects, economics, agriculture, conservation, and county government, including two ex officio members (Public Health Commissioner and State Planning Director) has been established. The Board has regulatory, enforcement, review, and compliance authority. The Board's jurisdiction covers all of Tennessee except Knox (Knoxville), Hamilton (Chattanooga), Davidson (Nashville) and Shelby (Memphis) Counties which are exempt by Board decision except that the Board reserves the right to enforce local regulations should the local agency fail to do so.

By law, the technical secretary to the Board is the Director of the Air Pollution Control Division. He may hold administrative hearings and has certain emergency authority during air pollution episodes. The Division is the administrative agency of the Board. Programs within the Division include the Engineering Program which issues permits, develops emissions inventories and equipment evaluations, and reviews Environmental Impact Statements; the Technical Services Program which handles monitoring, quality assurance, data processing and dissemination, and emergency episodes; the Surveillance and Enforcement Program which is responsible for complaints, surveillance, issues citations and participates in legal processes; an internal Division Administrative Program for personnel, procurement, training, etc.; and a source sampling section that runs the visible emissions training program. Information developed by several of these Division functions has been detailed in Section XII.

\section{FUTURE AIR POLLUTION REGULATION}

Since a realistic target date for tull-scale operation 1 s over a decale away, some inference is necessary regarding what possible future legislation may affect the project's air quality considerations. Given the dynamic nature of regulations in the past decade, there is a high probability that a number of changes, both technical and philosophical, may be expected in the next decade. The foundation for a number of changes has been laid in the Clean Air Act Amendments of 1977. After the Congress 
ceases to be actively involved in the decision-making process, much of the impetus of additional environmental regulation will revert back to interpretive rulings by the EPA Administrator. The manner in which the next 10 years evolve will depend upon a number of factors such as energy supply, economics, the role of the Third World as a supplier of of materials and energy, public support, the political situation, etc. Without a precise knowledge of these constraints, predicting future air quality strategies is an impossible task.

The current pattern of concern by Federal and local agencies can be analyzed and some structure of the more immediate possible changes to air quality regulation can be inferred. The areas where considerable effort is currently being placed include:

- Revision of air quality standards, both more or less stringent or for different time periods;

- Analysis of the synergism of several pollutant species acting in concert to create effects worse than for either pollutant acting alone;

- Super-regional fate of pollutants studies, especially gaseous pollutant conversion to particulate sulfates and nitrates and their impact hundreds or even thousands of miles from the source;

- Identification of carcinogenic or other hazardous substances present in the atmosphere in very small concentration;

- Modifications of State Implementation Plans to reflect realistic target dates for compliance for species whose natural background otten approaches the applicable standard;

- Technological breakthroughs in emission limitations for mobile sources (both light- and heavy-duty vehicles including planes and trains) and stationary sources (scrubbers, clean use of coal) and alternate energy source utilization;

- Increased emphasis upon the aesthetic and visible aspects of air pollution as opposed to actual health hazards;

- Increased public participation in the regulatory and review process. The manner in which these new directions in regulatory empahsis will affect the development of the Chattanooga Shale resource is difficult to furecast. Because of the lack of popular support for regulation that 
does not benefit the economic outlook of an area, strong polarization between accelerated growth and restricted growth ("environmentalist") forces will continue to occur. Given the magnitude of the proposed project, its development will assuredly provide a new battleground for the two contending philosophies.

\section{PROTECTED SPECIES}

Activities of the U.S. Fish and Wildlife Service could conceivably play a major role in determining the viability of a Chattanooga Shale uranium recovery project. The Endangered Species Act of 1973 provides that all Federal departments and agencies shall take such action as is necessary "to insure that actions authorized, funded or carried out by them do not jeopardize the continued existence of...endangered species and threatened species or result in the destruction or modification of habitat of such species which is determined...to be critical." Note that this wording is quite similar to wording contained within the National Environmental Policy Act. Thus, if an environmental impact analysis discloses that a project might threaten the continued existence of endangered species or adversely modify the habitat of such species, the project must be modified and/or eliminated.

The Fish and Wildlife Service is charged with determination of critical habitat for endangered species. If this agency were to determine that the area involved in a contemplated Chattanooga Shale mining venture constituted critical habitat for an endangered species, the project would have to be greatly modified or could well be completely eliminated. This situation is further compounded by the fact that the law permits citizen law suits to enjoin any person alleged to be in violation of any provision of the Endangered Species Act or any regulation adopted under authority of the Act.

Any proposed Chattanooga Shale uranium recovery project must take cognizant of these requirements and determine whether, in the opinion of the Fish and Wildlife Service, the critical habitat of endangered species might be impacted by proposed operations. For example, on December 30, 
1977, the Fish and Wildlife Service proposed to designate a portion of Coffee County, Tennessee, as critical habitat for the Barrens topminnow. This designation would effectively prohibit mining in any area potentially disturbing the designated habitat--Big Spring in Huntsville, Alabama and Duck River; West Fork Hickory Creek, and Collins River headwaters, Coffee County, Tennessee. Previous action by the Fish and Wildlife Service has resulted in the designation of a part of the Little Tennessee River in Loudon County, Tennessee as critical habitat for the snail darter.

\section{SOLID WASTES}

Regulations pertaining to solid wastes are administered at the Federal level by the EPA, and at the state level by the Tennessee Department of Public Health.

\section{FEDERAL REQUIREMENTS}

In October 1976, Congress passed the Resource Conservation and Recovery Act (RCRA). Regulations have not yet been promulgated under this legislation. The regulations will govern the disposal of solid waste, which is very broadly defined to include "solid, semi-solid, liquid, or contained gaseous" emissions from a number of industries including the mining industry. Hazardous waste is to be defined on the basis of criteria to be developed by the Environmental Protection Agency. The RCRA provides for interested states to develop a permitting program, somewhat similar to the NPDES program, to govern the generation, transportation, and disposal of hazardous wastes. In view of the radium which would be contained in the Chattanooga Shale waste, the waste products from mining and milling operations will probably fall under the provisions of RCRA. If so, a permit will be needed for mining, transportation, and waste disposal, with a manifest system and a complicated system of record keeping for the hazardous components contained within the solid waste. 


\section{STATE REQUIREMENTS}

House Bill No. 209, Public Acts of 1977, was signed into law on May 13, 1977. This bill, the "Tennessee Hazardous Waste Management Act," is designed to permit the Tennessee Department of Public Health to serve as the primary agency in enforcing provisions of the U.S. Resource Conservation and Recovery Act. In general, the existing rough draft of the Tennessee regulations attempts to track very closely with draft regulations proposed by the Environmental Protection Agency. Such regulations would provide for a licensing and permitting program for the production, transportation, and disposal of hazardous waste, incorporating a manifest system to assure proper disposal. It is almost certain that spent shale from any Chattanooga Shale leaching operation would contain sufficient radium to be classified as a hazardous waste, since draft criteria specify that any solid waste containing more than $3 \mathrm{pCi} / \mathrm{g}$ of radium-226 is a radioactive hazardous waste.

Regulations to be promulgated by this Act also will set criteria for the construction of tailings ponds and probably will require impervious liners under any pond facility. Design features for prevention of structural failure are also to be incorporated in the regulations.

The Tennessee Department of Public Health administers a radiological licensing program under an agreement signed with the NRC. However, for a project such as the Chattanooga Shale recovery scheme, it is certain that the Tennessee Department of Public Health would require compliance with all the NRC regulatory guidelines, such as Guideline 3.8 discussed earlier which specifies the content of an Environmental Report, together with guidelines covering the design and construction of waste impoundments and handling of liquid, gaseous, and solid wastes from the system.

The Tennessee Department of Public Health, Radiological Health Service, has adopted "State Regulations for Protection Against Radiation." There are tho specific provisions of these regulations which might bear upon operation of the contemplated project. The regulations specifically prohibit pond seepage. Also, the regulations (RHS 2.407) require that, 
prior to abandonment, the facility be decontaminated to levels consistent with the radiation levels in an unrestricted area. This requires cover over radioactive solid waste and the removal of contaminated equipment.

\section{NOISE}

The Environmental Protection Agency exercises control over noise generation throughout the United States, under the provisions of the Noise Control Act of 1972 (PL 92-574). The present regulatory activities which EPA is conducting under this law center in the area of setting noise emission standards for products sold in commerce. However, the Act does authorize EPA to begin collecting data on levels of ambient noise and the relationship of this noise to the public health and welfare. This will probably be used as a basis for future regulatory action governing the amount of ambient noise, in a matter similar to ambient air pollution standards.

\section{SURFACE MINING/RECLAMATION}

Regulations which may apply in the future to reclamation of surface-mined land will likely be promulgated at the Federal level by the Office of Surface Mining Regulation and Enforcement, and at the state level by the Tennessee Department of Conservation.

\section{FEDERAL REQUIREMENTS}

The Office of Surface Mining Reclamation and Enforcement (OSM) was created under the Surface Mining Control and Reclamation Act of 1977. As presently constituted, this Act provides for control over surface mining of coal. However, statements have already been made by Administration officials that a major effort will be expended to extend the aulhority under this Act to include all surface mining. The contemplated Chattanooga Shale project, with its high carbonaceous content of marine shale, would certainly be subject to early consideration for inclusion under this expansion: 
Regulations to be promulgated under the Surface Mining Control and Reclamation Act are not in final form. However, interim regulations were published in the December 13, 1977 Federal Register for lands covered by OSM, followed on December 16, 1977 by regulations covering Indian lands. The regulations as proposed require return of disturbed land to approximate original contour after mining. High walls and spoil banks are to be eliminated and potentially toxic or flammable material covered with a layer of inert material. Revegetation with material that is diverse, effective, permanent, and native to the area will be required, with revegetation bonds pending for periods of five to ten years after initial planting. The mine plan must provide for topsoil salvage and storage for subsequent reclamation. Interim stabilization measures will be required to reduce the amount of air and water pollution from exposed areas.

Some of the major provisions of the regulations deal with the subject of hydrologic protection. The gradient of alluvial streams, and the quality and quantity of surface and groundwater are to be protected, and measures taken to reclaim aquifers. Areas of prime farming land must especially be protected and rehabilitated to produce equivalent farming productivity.

As stated above, the final regulations for the OSM have not been promulgated nor do the regulations at present apply to mining of other than coal lands. However, it is virtually certain that by the time a project of uranium recovery from Chattanooga Shale will be operable, such regulations will be in existence and expanded to cover such mining operations. This would be irrespective of the type of land ownership in existence at the site, and without the restriction that it be on Federal lands.

\section{STATE REQUIREMENTS}

Legislation was introduced into the Tennessee legislature on January 18 , 1978 to provide that the Tennessee Department of Conservation, Surface Mining Division be permitted to assume primacy under the U.S. Dcpartment of Interior Office of Surface Mining Reclamation and Enforcement. It is the Tennessee intent to assume primacy in this Act, which presently limits only coal open pit mining. 
The Tennessee Department of Conservation, Surface Mining Division currently administers programs dealing with the surface mining of other minerals. of course, they presently have no guidelines which would cover a Chattancoga: Shale mining project, but they have experience in administering open pit mining programs for phosphate, clay, shale, and sand and gravel, as well as coal.

\section{WORKER SAFETY}

Activities of the Mine Enforcement and Safety Administration (MESA), U.S. Department of Interior (soon to be Mine Safety and Health Administrátion (MSHA), U.S. Department of Labor) will influence the contemplated project under its authority to establish conditions for miner health protection. Under the proposed plan for transfer to the Department of Labor, the activities of MESA and the activities of the Occupational Safety and Health Administration (OSHA) will be combined into a single operating body. This group will have responsibility for the health and safety aspects of mining operations and can play a major role in determining the viability of such operations. Regulations governing such items as roll-over protection for heavy equipment, radon daughter concentrations within mine air, and structural integrity of mine waste piles will be governed under the activities of MSHA. Such regulations are currently in a state of flux due to the pending transfer but will have a material impact upon the design of the uraniun recovery project.

\section{COUNTY REQUIREMENTS}

Most counties within the Chattanooga Shale regional study area do not have a countywide zoning ordinance. In general, zoning requirements are applicable only within incorporated cities. It is possible that a county zoning ordinance could be developed prior to initiation of the project, but this appears extremely unlikely given the present climate toward zoning. In general, the policy seems to be to provide a wide degree of latitude of activities to be conducted on private lands outside of incorporated areas. Thus, regulations at the county level are not expected to influence a Chattanooga Shale project. 
Any cousideration of large-scale recovery of uranium from the Chattanooga Shale must be cognizant of a rumber of existing pieces of legislation and regulations at the Federal level and companion legislation and regulations at the state leve]. Such a project also must be designed with an awareness of a rapidly changing regulatory program, which probably will become increasingly stringent.

Development of a uranium recovery project such as envisioned should begin with the preparation of an Environmental Impact Statement. Such a statement should serve to define the potential detrimental effects of the project and enumerate mitigating measures to be taken to minimize the adverse effects. Such a statement will take at least 2 years to prepare and should be available as long as possible in advance of project initiation, probably another 2 years.

Actual project design and construction will be affected by the NPDES permit program for surface water discharges. This program, administered by the Tennessee Department of Public Health, requires a permit application at least 180 days prior to start of operation. In actual practice, the application should be filed 2 years before start. of operations.

Control of pond seepage and possible groundwater pollution will probably be achieved according to regulations promulgated uncler authority of either the Resource Conservation and Recovery Act or the Safe Drinking Water Act, and probably will involve use of impermeable pond liners. Disposal of hazardous solid waste will be achieved under RCRA, through a permit program using a manifest system.

The State of Tennessee Department of Public Health administers the majority of the programs of significance within the state of Tennessee, with Federal agency overview. Tennessee is currently reviewing the state environmental posture. 
Compliance with existing and expected future regulations will be one of the most critical requirements for development of a Chattanouga Shale uranium recovery project. It is by no means an impossible task, but a continuing program which must have its beginning several years in advance of construction activities.

\section{SUMMARY}

Project impacts have been analyzed in terms of total pollutant emissions, and those emissions have then been translated into an ambient air quality impact through accepted diffusion modeling methodologies. The principal pollution sources and their attendant emissions increases are as follows:

Source

Mining Operations

Processing Operations

Traffic Growth
Emissions per day

2,100 pounds of particulates, 2,200 pounds of gaseous pollutants, principally oxides of nitrogen

72,000 pounds of sulfur dioxide, 10,000 pounds of oxides of nitrogen, minor amounts; of carbon monoxide, hydrocarbons and particulates

Pollutants from an additional 465,000 vehicle miles traveled on DeKalb County roads

Converting these emissions into resulting air quality degradation yields the following values:

$\underline{\text { Maximum Impact }}$

Particulate impact

So, impact of Retining Operations

CO impact from synthesized worst-case traffic pattern

\section{Concentration}

$5 \mu \mathrm{g} / \mathrm{m}^{3}$

annual average

$20 \mu \mathrm{g} / \mathrm{m}^{3}$

annual averáge

$35 \mu \mathrm{g} / \mathrm{m}^{3}-$

6. $1 \mathrm{ppm}$
Percent of Applicable Standard

$8 \%$ of annual standard

$25 \%$ of the annual standard

$25 \%$ of the three-hour standard (if the conditions persist three hours)

$20 \%$ of the hourly CO standard 
The baseline air quality is sufficiently good to allow for the above incremental degradation without violating air quality standards. Based upon this preliminary analysis, the rural environs of central Tennessee and other portions of the Chattanooga Shale study area could accommodate development of a massive recovery project while meeting all local, state and Federal air quality requirements. 
SECTION XV

ANNOTATED BIBLIOGRAPHY

Allard, H.A. "A List of Plants Collected at Thompson's Mills, Jackson County, in Northern Georgia." Castanea 9:135-140. 1944.

Allen, Timothy F. "Additional Observations of the Flora of Lookout Mountain." Bull. Torr. Bot. Cl. 1:29-30. 1870.

Thirty-three species listed from North Georgia.

Anderson, W.A., Jr. "A List of Tennessee Ferns." Amer. Fern. Jour. $20: 143-150$. 1930 .

Preliminary list of whole state. Superceded by Shaver's later work.

Ash, E.C., Jr. "Some Reptiles from Southeastern Tennessee and North Georgia." Jour. Tenn. Acad. Sci. 20:261-265. 1945.

Ashton, T.E. "An Annotated List of the Order Caudata (Amphibia) of Davidson County, Tennessee." Jour. Tenn. Acad. Sci. 41:106-111. 1966.

Thorough, annotated list of the salamanders of Davidson County, Tennessee.

Baldwin, John L. Climates of the United States. National Oceanic and Atmospheric Administration Environmental Data Service. 1973.

General climatic description of mean and extreme climatic conditions for the United States. Discussion of climate and its causes, the relationship of geography and climate and a brief discussion of climatic controls precedes detailed breakdowns of winter and summer climatic conditions and annual distributions of various elements shown on 63 United States maps. 
Barbour, R. W. Amphibians and Reptiles of Kentucky. University of Kentucky Press. 1971. $334 . p p$.

General summary of whole state with keys and notes.

Barbour, R. W. and B. L. Barbour. "Notes on the Plants of Harlan County, Kentucky." Castanea 15:125. 1950.

Barge, Waggoner and Sumner Inc., Engineers and Planners, and SmithvilleDeKalb County Model City Planning Office. General Plan. 1969.

Background includes historical, economic, population and physical environment. General Plan objectives are described as planning concepts, plan for land use, plan for thoroughfares, plan for public facilities, and neighborhood housing analysis. In addition, there is a general implementation plan including a public improvement program and regulatory measures.

Barren River Area Development District. Integrated Program Design. 1977.

This document describes the overall economic development program of the Barren River Area Development District. It is designed to be comprehensive in nature and provide a general overview of economic development factors. It aiso examines the problems, needs, and résources of the BKAUV and sets torth the goals of the development, program, together with a strategy to achieve the goals.

Baskin, C.C. anc J.M. Baskin. "Additions to the Herbaceous Flora of the Middle Tennessee Cedar Glades." Jour. Tenn. Acad. Sci. 50:25-26. 1975 .

. "The Cedar Glade Flora of Bullitt County, Kentucky." Castanea 40:184-190. 1975 .

Baskin, J.M. and C.C. Baskin. "An Undescribed Cedar Glade Community in Middle Tennessee." Castanea 42:140-145. 1977.

Describes a community dominated by little bluestem (Andropogon scoparius) in Wilson County. Includes a list of accompanying taxa. 
Baskin, J.M., E. Quarterman, and C. Caudle. "Preliminary Check-list of the Herbaceous Vascular Plants of Cedar Glades." Jour. Tenn. Acad. Sci. 43:65-71. 1968 .

Valuable list of plants of unusual interest and numbers of endemics.

Beatley, J. "The Sunflowers (Genus Helianthus) in Tennessee." Jour. Tenn. Acad. Sci. 38:135-154. 1963.

State-wide list with distributions.

Bishop, G.N. Native Trees of Georgia. Div. of Forestry, Ga. Agr. Exp. Sta. Athens, Georiga. 1940.

Blanchard, F.N. "The Amphibians and Reptiles of Western Tennessee." Occas. Pap. Mus. Zool. Univ. Mich. 117:1-18. 1922.

Blauch, D.C. "Toward a Natural Delineation of the Area Known as the Southern Appalachian Highlands." Castanea 40:197-201. 1975.

Includes DeKalb County, Tennessee, in the Southern Appalachian Highlands Region.

Branson, E.R. Economic Geology of Allen County, Kentucky. Kentucky Geological. Survey, County Report 1, Series X. University of Kentucky. 1966.

Braun, Lucy. "Some Relationships of the Flora of the Cumberland Plateau and Cumberland Mountains in Kentucky." Rhodora 39: 193-208. 1937.

Braun, E.L. An Annotated Catalog of Spermatophytes of Kentucky. Pub. by Author. Cincinnati. 1943.

Briggs, G.A., Plume Rise. AFC Critical Review Series. NTIS TID-25075. USAEC Technical Information Center. 1969.

Brigham, W.U. "Longitudinal distribution of the stream fishes of Putnam County, Tennessee." M.S. Thesis, Tennessee Technological University, 1966.

Good local list of stream fishes. 
Brown, R.F., and T.W. Lambert, Availability of Ground Water in Allen, Barren, Edmonson, Green, Hart, Logan, Metcalfe, Monroe, Simpson, and Warren Counties, Kentucky. U. S. Geological Survey, Prepared in Cooperation with Kentucky Geological Survey, University of Kentucky, Hydrologic Atlas HA-32. 1962.

Bryan, P. and L. F. Miller. "Changes in the Commercial Fishery on the Alabama Portion of the Tennessee River." TVA, Fish and Wildlife Branch Report. 1952 .

Burchett, Charles R. Water Resources of the Upper Duck River Basin, Central Tennessee. Tennessee Department of Conservation, Division of Water Resources. Water Resources No. 12. 1977. 103 pp.

Describes the suitability of the various water resources of the upper Duck River Basin for obtaining water supplies. Designed to aid the water user and water manager in the development of potable water supplies.

Burchett, Charles R. and Gerald K. Moore. Water Resources in the Uppper Stones River Basin, Central Tennessee. Tennessee Department Conservation, Division of Water Resources. Water Resources Series No. 8. 1971. $62 \mathrm{pp}$.

Describes the water resources of the upper Stones River basin, and the chances for obtaining specific amounts of. water from various ground and surface sources in the basin. Specific topics include: chemical quality of the water; physical geography and gelogy; flooding.

Byford, J.L. Beavers in Tennessee: Control, Utilization and Management. Agric. Ext. Serv. Univ. of Tenn. 1974.

Caplenor, C.D. "An Annotated List of the Vascular Plants of the Georges of the Fall Creek Falls State Park." Jour. Tenn. Acad. Sci. 30: 93-108. 1955.

Caplenor, Donald. "The Vegetation of the Gorges of the Fall Creek Falls Stale Park in Tennessee." Jour. Tenn. Acad. Sci. 40:27-39. 1965.

- "Woody Plant of the Gorges of the Southern Cumberland Plateau and Adjacent Highland Rim." Submitted to Amer. Midl. Nat. February, 1978. (In press). 
Carpenter, L.J. Turner, and J. Schibig. "Forest Communities of the Radnor Lake Natural Area, Davidson Co., Tennessee." Jour. Tenn. Acad. Sci. 51:68-72. 1976.

Contains a list of woody plants of an outlier of the Eastern Highland Rim near Nashville.

Carroll, Gladys. "The Bryophytes of the Appalachian Plateau in Northern Georgia." Bryologist 48:11-24. 1945.

Annotated lists of mosses and liverworts of Dade and adjoining counties.

Cary, C.A., E.R. Miller, and G.R: Johnstone. Poisonous plants of Alabama. Ala. Poly. Inst. Ext. Serv. Circ. 71. 1924. 42 pp.

State-wide survey of poisonous plants.

Chandler, C.M. "A Preliminary Checklist of Benthic Macroinvertebrate Families from Basket Sampling during Early Summer in the West Fork of Stone's River, Tennessee." Jour. Tenn. Acad. Sci. 53: 25-28. 1978.

Families of macroinvertebrates (aquatic) from Rutherford County, Tennessee.

Clark, 0.M., Jr. Clay and Shale of Northeastern Alabama. Geological Survey of Alabama, Circular. No. 20C. 1968.

Clark, Ross C. "Woody Plants of Allabama." 'Ph.D. Dissertation. Univ. of North Carolina. 1972.

County records of woody plants throughout Alabama.

Clebsch, A. "Interesting Bryophytes from Tennessee." Castanea 19: 1-20. 1954.

Minor list of mosses and liverworts, mostly from Montgomery County, Tennessee.

Cole, M.E. "Seven New Ostracods from Tennessee." Jour. Tenn. Acad. Sci. $40: 132-142.1965$. 
Conway. Publications Inc. and Department of Economic and Community Development. Tennessee. 1977.

Evaluates Tennessee's potential for economic expansion. Covers principal taxes on corporations, education and industrial training. Financing, utilities and industrial development site selection handbook.

Cook, E.W. "Organic Acids in Process Waters from Oil Shale." Chemistry and Industry. 'May 1971.

Copeland, J.E. "Some Characteristics of a Gray Squirrel Population at Shipley Farm, Putnam County, Tennessee." 1976.

Contains a good upland hardwoods plant list of Eastern Highland Rim.

Cressler, Charles W., Marvin A. Franklin, and Willis G. Hester. Availability of Water Supplies in Northwest Georgia. Georgia Department of Natural Resources, geologic and water resources division. Prepared in cooperation with the U.S. Geological Survey. Bulletin 91. 1976. 140 pp.

Indicates quantity and chemical quality of water available from wells, springs, and streams in the 10 counties of northwest Georgia.

Cronquist, A.J. "Noteworthy plants of Georgia." Castanea 14: 101-108. 1949 .

Includes many plants of Appalachian Georgia.

Davies, P.A. "A Preliminary List of the Vascular Plants of Mammoth Cave National Park." Castanea 20:107-127. 1955.

Plants of south-central Kentucky.

DeLotelle, R.S. "A Herpetological Survey of a Mixed Mesophytic Forest on the Eastern Highland Rim, Tennessee." M.S. Thesis. Tennessee Technological University. 1976.

Study in Overton County. Good local list for Eastern Highland Rim. 
DeSelm, H.R. "A New Map of the Central Basin of Tennessee." Jour. Tenn. Acad. Sci. 34:66-72. 1959.

This also defines the limits of the Eastern Highland Rim. DeKalb County contains both Outer Basin and Eastern Highland Rim.

Dills, G.G. "The Effects of Prescribed Burning upon Quantity and Quality of Deer Browse on the Catoosa Wildlife Management Area, Morgan and Cumberland Counties, Tennessee." M.S. Thesis. Tennessee Technological University. 1969.

Limited list of plant species.

Dimmick, Ralph W. "The Distribution of Microtus ochrogaster in Tennessee." J. Mammal. 50:126. 1969 .

Duncan, S.H. and W.H. Ellis. "An Analysis of the Forest Communities of Montgomery County, Tennessee." Jour. Tenn. Acad. Sci. 25-32. 1969.

Duncan, W.H. "Preliminary Reports on the flora of Georgia. 2. Distribution of 87 trees." Am. Midl. Nat. 43:742-761. 1950. Includes maps showing tree distribution in Georgia. 1967.

"Woody Vines of the Southeastern States. Sida 3: 1-76.

Comprehensive guide includes Georgia and Tennessee.

Ellis, W.H., E. Wofford, and E.W. Chester. "A Preliminary Checklist of the Flowering Plants of the Land Between the Lakes." Castanea 36:229-246. 1971 .

Lists and short introduction--no annotations.

Endsley, J.R. "An Annotated Listing of a Herpetological Collection Mainly from Tennessee." Jour. Tenn. Acad. Sci. 29:36-41. 1954.

Field, R.J. "Observations on the Presence of Furbearers in the Sequatchie River, Tennessee." Jour. Tenn. Acad. Sci. 53:37-40. 1978. 
Brief summary of signs of aquatic mammals of the Sequatchie River Valley.

Freeman, C. P. "Ecology of the Cedar Glade Vegetation near Nashville,

Tennessee." Jour. Tenn. Acad. Sci. 8:143-228. 1933.

Ecological treatment. Contains a list of plants in the center of the Cedar Glades near LaVergne, Tennessee.

Garren, K. H. "Effects of Fire on Vegetation in Southeastern United States." Bot. Rev. 9:617-654. 1943.

Garton, J.S. "Food Habits of the Copperhead in Middle Tennessee." M.S. Thesis. Tennessee Technological University. 1967.

Mostly related to Cumberland Plateau, but lists relevant to Dekalb County.

Gattinger, Augustin. The Tennessee Flora with Special Reference to the flora of Nashville. Pub. by author. Nashville, Tennessee. 1887 .

- The Medicinal Plants of Tennessee. Tenn. Dept. of

Agric. Printed by F. M. Paul. 1894.

- The Flora of Tennessee and A Philosophy of Botany. Gospel

Advocate Pub. Co. Nashville, Tennessee. 1901.296 pp.

Most complete early work on the plants of Tennessee. Of great scientific and historical interest.

Gentry, G. "An Annotated Check List of the Amphibians and Reptiles of Tennessee (Part 1)." Jour. Tenn. Acad. Sci. 30:168-176. 1955.

. 1956. "An Annotated Check List of the Amphibians and Reptiles of Tennessee (Part 2)." Jour. Tenn. Acad. Sci. 31:242-251. 1956.

Geological Survey of Alabama. Environmental Geology and Hydrology, Huntsville and Madison County, Alabama. Atlas Series 8. 1975. 
Gibson, A.M. Report on the Coal Measures of Blount Mountain. Geological Survey of Alabama, Special Report No. 5. 1893 (out of print).

- Report on the Geological Structure of Murphree's Valley, and Its Minerals and Other Materials of Economic Value. Geological Survey of Alabama, Special Report. 4. 1873. (out of print).

Gifford, F.A. "Use of Routine Meteorological Observations for Estimating Atmospheric Dispersion." Nuclear Safety 2:47-51. 1961.

Gildersleeve, Benjamin. "Geology of the Fountain Run Quadrangle, Kentucky-Tennessee". U.S. Geological Survey, Geological Quadrangle Map GQ-194. 1962.

Goodwin, J.T. "An Annotated List of the Tabanidae of Tennessee." Jour. Tenn. Acad. Sci. 41:114-115. 1966.

No records from DeKalb County, but some from nearby counties.

Green, Earle R., W.W. Griffin, E.P. Odum, H.L. Stoaddard. Birds of GeorgiaA Preliminary Check-list and Bibliography of Georgia Ornithology. Univ. of Georgia Press. Athens, Georgia. 1945. 111 pp.

Guthrie, P.A. "A Survey of the Benthic Macroinvertebrate Communities in the Cumberland River and Dixon'Creek in the Vicinity of the Proposed Hartsville Nuclear Power Plant." M.S. Thesis. Tennessee Technological University. 1977.

Exhaustive list of local macroinvertebrates.

Hale, W.T. History of DeKalb County, Tennessee. (Reprinted in 1969 by Ben Lomand Press, McMinnville, Tennessee) 1915.

Hall, R.C. Preliminary Study of the Forest Conditions in Tennessee. Tenn. Geol: Survey Services. 10A:1-56. 1910.

Hamilton, Warren. "Geology of the Fountain Run Quadrangle, KentuckyTennessee". U.S. Geological Survey, Geological Quadrangle Map GQ-254. 1963. 
Hanna, S.R. "Relating Emissions to Air Quality in Tennessee." ATDL Contribution File No. 90. 1974.

This paper describes a simplified dispersion model that relates the concentration in terms of emissions, wind speed and a dimensionless dispersion parameter that essentially produces a "box model" solution of atomospheric dispersion. The model was applied to 95 counties in Tennessee and gave reasonable agreement once the dispersion parameter was determined from available data.

Hanna, S.R., C.J. Nappo, R.P. Hooker and G.A. Briggs." Description of the Eastern Tennessee Trajectory Experiment (ETTEX)." Paper presented at the first AMS conference on Regional and Mesoscale Modeling, Analysis and Prediction. Las Vegas, Nevada. May 6-9, 1975.

The eastern Tennessee trajectory experiment was conducted during July and August, 1974. Its objective was to measure messocale transport and diffusion parameters in complex flow over the Cumberland Plateau and the Tennessee River Valley. This report describes the overall project philosophy and design. More detailed analyses appear in later publications.

Hannum, Curtis $H$. Technique for Estimating Magnitude and Frequency of Flonds in Kent.ucky. U. S. Geological Survey, Prepared in Cooperation with the University of Kentucky and Kentucky Geological Survey, Water Resources Investigations 76-62. 1976.

Harper, R. M. "A Botanical Cross-Section of Northern Mississippi." Bull. Torrey Bot. Club.. 40:377-399. 1913.

Soils and plant zones in northern Mississippi. 1926 .

"The Cedar Glades of Middle Tennessee." Ecology 7: 48-54.

A cursory report on the glades near Lebanon, Tennessee.

. "Economic Botany of Alabama, Part 2." Geol. Survey of

Alabama Monogr. 91928. 
- The Natural Resources of Georgia. Bull. Univ. Ga. No. 30 Athens, Georgia. 1930. 105 pp.

Resources catalog, including plants.

- "A Depressed Outlier of the Cumberland Plateau in Alabama and its Vegetation." Castanea 2: 13-18. 1937.

- Natural Resources of the Tennessee Valley Region in Alabama.

Geo1. Survey Ala. Spec. Report 17. 1942.

. "Hemlock in the Tennessee Valley of Alabama:" Castanea

$8: 115-123,1943$.

- Forests of Alabama. Geol. Surv. Ala. Monogr. 10. 1943.

- Preliminary Report on the Weeds of Alabama. Geological

Survey of Alabama, Bulletin 53. 1944. 275 pp.

Harris, E.W. "Distribution of the Herpetofauna of Davies Island, Center Hill Reservoir." Jour. Tenn. Acad. Sci. 42:87-92. 1967.

Lists of amphibians and reptiles according to plant association on the island in DeKalb County.

Haynes, D.D. "Geology of the Lucas Quadrangle, Kentucky". U. S. Geological Survey, Geological Quadrangle Map GQ-251. 1963.

Hemmerly, T.E, and E. Quarterman. "Optimum Conditions for the Germination of Seeds of Cedar Glade Plants: A Review." Jour. Tenn. Acad. Sci. 53:7-11. 1978 .

Reviews work on germination of seeds of glade plants, much done earlier by Baskin and Baskin.

Henry, D.L. "Distribution of Small Mammals on Davies Island, Center Hill Reservoir, Tennessee." Master's Thesis. Tennessee Technological University, 1975.

Holtzclaw, F.W. "Floristie Survey of Spring Flowering Herbs at Frozen Head State Park, Morgan Co., Tennessee." Jour. Tenn. Acad. Sci. 52:5-9. 1977. 
List of plants including some rare taxa.

Holzworth, George C. "Mixing Heights, Wind Speeds and Potential for Urban Air Pollution throughout the Contiguous United States."

- Environmental Programs Office Publication No. AP-101. 1972.

This publication presents a series of isopleth maps and data tabulations of the dilution potential throughout the United States. Breakdowns of the mixing height wind speed product and episodes of restricted ventilation in 500 meter mixing height, $2 \mathrm{~m} \mathrm{sec}{ }^{1}$ wind speed groups and episodes of 2 or 5 days are shown in 71 maps of U.S. dilution potential.

. "Climatological Data on Atmospheric Stahility in the United States." Paper presented at American Meterological Society Symposium on Atmospheric Diffusion and Air Pollution. September 9-13, 1974.

Discusses the methodology for evaluating upper atmospheric data and gives representative results for a number of United States stations. Complete results from this study are contained in EPA 650/4/74/002.

- Meteorological Episodes of Slowest Dilection in the Contiguous United States. U. S. Environmental Protection Agency, National Environmental Resealla Cenler. EPA bjo/4//4/002. 1974.

Five years of mixing layer and wind speed data have been summarized to determine episodes of restricted ventilation $1,2,3,4$ and 5 days for 62 stations in the United States. Results are presented in isopletn maps and in tabular form.

Hopkins, William B. Geology and Groundwater Resources of the Scottsville Area, Kentucky. U. S. Feological Survey, Prepared in Couperation with the Commonwealth of Kentucky, Department of Economic Development and the Kentucky Geological Survey, University of Kentucky, Water Supply Paper 1528. 1963.

Howell, J.C. and C.H. Conaway. "Observations of the Mammals of the Cumberland Mountains of Tennessee." Jour. Tenn. Acad. Sci. 27: 153-158. 1952. 
Isely, D. Manual of Herbaceous Plants of the Tennessee Valley Reservoirs. TVA, Health and Safety Dept. Malaraia Control Div. 1946. 185 pp.

Isom, B.G. "Effects of Storage and Mainstream Reservoirs on Benthic Macroinvertebrates in the Tennessee Valley." in G. E. Hall, ed. Reservoir Fisheries and Limnology. Spec. Pub. No. 8. Amer. Fish. Soc., Washington, D. C. 1971.

Institute of Gas Technology. Program Plans for the Development of the IGT Oil Shale Process. Institute of Gas Technology, Chicago, Illinois. 1973. $37 \mathrm{pp}$.

See Section VI, Volume for annotation.

Jackson, G.T., S.R. Bacon, and B.C. Cox. Soil Survey of Putnam County, Tennessee. U. S. Department of Agriculture. 1963. 114 pp. +55 sheets of maps.

Excellent survey of a county with a long stretch of border with DeKalb County.

Jackson, I.P., R.E. Poulson, et al. "Characteristics and Possible Roles of Various Waters Significant to In Situ Oil Shale Processing." Proceedings of the Environmental Oil Shale Symposium. Colorado School of Mines, 1975.

James, R.L. "Mistletoe in Tennessee." Castanea 13:91-95. 1958.

Jennison, H.M. "A Preliminary Check-list of the Spring Wild Flowers and Ferns of Tennessee." Jour. Tenn. Acad. Sci. (Supplement) 4: 1-32. 1929.

Early preliminary list.

Johnson R.G. "Notes on the Distribution of Disporum maculatum (Buckl.) Britton." Castanea 33:262-266. 1968.

Includes a collection in DeKalb County erroneously attributed to Putnam County.

Johnson, R.M. "A Biogeographic Study of the Herpetofauna of Eastern Tennessee." Ph.D. Dissertation. University of Florida. 1958. 
- The Herpetofauna of the Oak Ridge Area. ORNL Publ. No. 3653.

Oak Ridge, Tennessee. 1964. 29 pp.

Johnson, William Drumm, Jr. Ground Water in the Paleozoic Rocks of Northern Alabama. Geological Survey of Alabama Special Report 16. 1933. $414 \mathrm{pp}$.

Describes the climate, geology, physiography, ground water, caves, water in mines, chemical character of natural waters and the water bearing properties of the different formations. Descriptions are provided for 25 northern Alabama counties, including DeKalb County.

Johnston, W.D., Jr. Ground Water in the Paleozoic Rock of Northern Alabama, Part 1, Text, Part 2, Well and Spring Tables. Geologic Survey of Alabama, Special Report No. 16. 1933.

Jones, D.A. Andrew. "Application of Geo-thermal Techiques to Mineral Exploration." Minerals Institute Bulletin 2:6. 1968.

Jordon, O.R., J.S. Garton, and R.F. Ellis. "The Amphibians and Reptiles of a Middle Tennessee Cedar Glade." Jour. Tenn. Acad. Sci. 43:72-78. 1968 .

Kellogg, R. "An Annotated List of Tennessee Mammals." Proc. U. S. Nat1. Mus. 86:245-308. 1939 .

Ketner, K.B. "Geology of the Scottsville Quadrangle, Kentucky." U. S. Geological Survey, Geological Quadrangle Map GW-184. 1962.

Killebrew, J.B. The Grasses of Tennessee, Inc. Cereals and Forage Plants. American Co. Nashville, Tennessee. 1878. 511 pp.

- Grasses and Forage Plants (of Tennessee). Univ. of Tennessee Press. Knoxville, Tennessee. 1898. 144 pp.

Kondratieff, Boris C. and J.W.S. Foster III. "Some Mayflies of Middle and East Tenessee." Jour. Tenn. Acad. Sci. 52:112. 1977.

Reports from nearby counties. One report from DeKalb County. 
Korshover, J. "Climatology of stagnating anti-cyclones last of the Rocky Mountains, 1936-1975". Air Resources Lab., TM ERL ARL-55. 1976 .

This study presents maps of the maximum seasonal frequency of stagnation (centers of anticyclones) showing the strong influence of the Bermuda High on the East Coast as it migrates north and south.

Kra1, R. "Some Notes on the Flora of the Southern States, Particularly Alabama and Middle Tennessee." Rhodora 75:366-410. 1973.

Thorough and authoritative report on plants of the area.

. "Additions to Some Notes on the Flora of the Southern States, Particularly Alabama and Middle Tennessee." Rhodora 78: 438-456. 1976.

Krisch, L.A. "Notes on a Collection of Fishes from the Southern Tributaries of the Cumberland River in Kentucky and Tennessee." U.S. Fish Commission Bull. 11:257-268. 1893.

Kuhne, E.R. A Guide to the Fishes of Tennessee and the Mid-South. Tenn. Dept. of Conservation. Nashville. 1939. 124 pp. An excellent general and unsophisticated guide.

Lake Cumberland Area Development District, Jamestown, Kentucky. Comprchencive Homsing Action Plan. 1977a.

This report presents an evaluation of pertinent historical data on housing and an analysis of recent housing activities in the LCADD including, apparent problems and obstacles to housing: the construction and demolition of units; past and existing trends in structural conditions; public housing and other low- and moderate-income housing activities; the availability of land and financing; and other such elements.

- Data Resources for the Lake Cumberland Area Development District. An Excerpt from the Areawide Action Plan. 1977b. 
Data Resources for the Lake Cumberland Area Development District is a compilation of the most frequently used statistical information for this ten-county area. It is an excerpt of the data portion of the areawide action plan for FY-77, funded by the Appalachian Regional Commission.

Lamson-Scribnex, F. "The Grasses of Tennessee, Part I." Bull. Agr. Expt. Sta. of Univ. of Tenn. 5:29-119. 1892. . "Grasses of Tennessee, Part II." Bull. Agric. Exp. Sta. of Univ. of Tenn. 7:1-141. 1894 .

Litchford, R.G., S. Morse, and S. Wages. "An Assessment of Some Environmental Changes at TVA's Sequoyah Nuclear Plant." Jour. Tenn. Acad. Sci. 53:23-25. 1978.

Effects of thermal changes on fish and fish parasites.

McCalley, Henry. Report on the Valley Regions of Alabama (Paleozoic Strata), Part 1 , On the Tennessee Valley Region. Geological Survey of Alabama, Special Report No. 8. 1896 (out of print).

McCalley, Henry, and A.M. Gibson Report on the Coal Measures of the Plateau Kegion of Alabama, Including a Report on the Coal Measures of Blount County. Geological Survey of Alabama, Special Report 3 . 1891 (out of print).

McGill, J.T. "Ferns Found in the Vicinity of Sewanee." Trans. Tenn. Acad. Sci. 2:66-68. 1917.

McGilliard, E. "The Family Liliaceae in Tennessee." Jour. Tenn. Acad. Sci. 30:19-26. 1955.

McGlamery, Winnie. Subsurface Stratigraphy of Northwest Alabama. Geological Survey of Alabama, Bulletin No. 64. 1955 (out of print).

Migrant, The - A quarterly journal devoted to Tennessee birds. 
Published continuously by the Tennessee Ornithological Society since 1930. All articles pertinent to Tennessee natural history. A species index for Vols. 1-47 (1930-1976) was published in 1977 by the Tennessee Ornithological Society.

Miller, A.M. "Allen County, Map of". 1920.

County maps show geologic information-areal geology, surface or subsurface structure, ordinarily with oil and gas and other mineral development - predate Series X publications, pre-1958.

- "Geology of Allen County". in The Mineral and Forest Resources of Kentucky. Kentucky Department of Geology and Forestry, Ser. 5, V. 1. 1919.

Miller, R.A. The Geologic History of Tennessee. Division of Geology, Nashville, Tennessee. 1974. 63 pp. + separate map.

This geologic treatment approaches the physiographic regions of DeKalb County differently from DeSelm in that Miller extends the Central Basin Eastward along the Caney Fork River almost through DeKalb County to the White County line.

Mohr, C. Plant Life of Alabama. U. S. Nat. Herbarium. Vol. 6. Washington, D. C. 1901. $921 \mathrm{pp}$.

Excellent general work on flora and physiography.

Moore, Gerald K., and John M. Wilson. Water Resources of the Center Hill Lake Region, Tennessee. State of Tennessee, Department of Conservation, Division of Water Resources, Water Resources Series No. 9.1972 .

Moore, S.L. "Gcology of the Austin Quadrangle, Kentucky". U. S. Geological Survey, Geological Quadrangle Map GQ-1/3. 1961.

. "Geology of the Tracy Quadrangle, Kentucky". U. S.

Geological Survey, Geological Quadrangle Map GQ-217. 1963a. 
. "Geology of the Drake Quadrangle, Kentucky". U. S. Geological Survey, Geological Quadrangle Map GQ-277. 1963h.

. "Geology of the Allen Springs Quadrangle, Kentucky". U. S. Geological Survey, Geological Quadrangle Map GQ-285. 1963c.

. "Geology of the Hickory Flat Quadrangle, Kentucky-Tennessee". U. S. Geological Survey, Geological Quadrangle Map GQ-420. 1965.

Moser, P.H. and L. W. Hyde Environmental Geology and Hydrology, Madison County, Alabama, Madison Area. Geological Survey of Alabama in Cooperation with the U. S. Geological Survéy, Atlas Series 5. Intermin Report. 1973.

- Environmental Geology: An Aid to Growth and Development in Lauderdale, Colbert, and Franklin Counties, Alabama, Geological Survey of Alabama, Atlas Series 6. 1975.

- Environmental Geology and Hydrology, Madison County, Alabama, Maysville Area. Geological Survey of Alabama in Cooperation with the U. S. Geological Survey, Atlas Series 3, Intermin Report. 1972 .

Mull, D.S., R.V. Cushman and T. Wm. Lambert. Public and Industrial Water Supplies of Kentucky, 1968-69. U. S. Gelogical Survey, Prepared in Cooperation with the Kenturky frenlngical Survey. Information Circular 20, Kentucky Geological Survey, Series X. 1971.

Myers, W.B. "Geology of the Petroleum Quadrangle, Kentucky-Tennessee". U. S. Geological Survey, Geological Quadrangle Map GQ-352. 1964.

Nave, Edward. Tennessee's Water Resources. State of Tennessee, Department of Conservation, Division of Water Resources.

Neil, W.T. "The Lizards of Georgia". Herpetologica 4: 153-158. 1948.

Nelson, W.H. "Geology of the Holland Quadrangle, Kentucky-Tennessee". U. S. Geulogical Survey, Geological Quadrangle Map GQ-174. 1962.

- "Geology of the Meador Quadrangle, Kentucky". U. S. Geological Survey, Geological Quadrangle Map GQ-288. 1963. 
"Geology of the Adolphus Quadrangle, Kentucky-Tennessee". U. S. Geological Survey, Geological Quadrangle Map GQ-299. 1964.

O'Neil, R.L. "A Study of Trace Element Distribution in the Chattanooga Shale". Thesis. Pennsylvania State University. 1956.

(See Section VI for Annotation)

Pasquil1, F. "The Estimation of the Dispersion of Windborne Material". Meteorological Magazine, 90:33-49. 1961.

Patterson, Reid. "An Interpretation of Recent Discoveries in Kentucky's Allen County Area". In Proceedings of the Technical Session, Kentucky Oil and Gas Association Annual Meeting, June 3, 1960. Kentucky Geological Survey Special Publication 3, Series X. 1960.

Peck, G.E. "Changes in Benthic Macroinvertebrates upon Impoundment of Cordell Hull Reservoir". M.S. Thesis. Tennessee Technological University. 1974.

Penfound, W.T., T.F. Hall, and A.D. Hess. The Spring Phenology of Plants In and Around the Reservoirs in North Alabama". Ecology $26: 332-352$. 1945 .

Complete list of Tennessee Valley plants in North Alabama-particularly good on aquatics.

Pierce, Laurence B. Special Report 24, Surface Water Resources and Hydrology of West Central Alabama. United States Geological Survey in cooperation with the Geological Survey of Alabama. 1959. 236 pp.

Describes water use and control; hydrologic environment; streamflow records and characteristics; the chemical quality of surface waters of west-central Alabama. Covers all or parts of 21 of the 67 Alabama counties.

- Reservoir Temperatures in North-Central Alabama. Geological Survey of Alabama, Bulletin No. 83. 1964.

- Surface Water Resources and Hydrologyy of West-Central Alabama Geological Survey of Alabama, Special Report 24. 1959. 
Quarterman, E. "Ecology of Cedar Glades. I. Distribution of Glade Flora in Tennessee". Bull. Torr. Bot. Club 77:1-9. 1950a.

_Major Plant Communities of Tennessee Cedar Glades. Ecology 31:234-254. 1950b.

Reynolds, J.W.. "Checklist, Distribution and Key to the Lumbricidae in Tennessee. Jour. Tenn. Acad. Sci. 49:16-20. 1974.

Robinson, F.D. and R.E. Shanks. "Checklist of Vascular Aquatic Plants of Tennessee". Jour. Tenn. Acad. Sci. 34:58-65. 1959.

Rogers, K.E. and D.F. Bowers. "Notes on Tennessee Plant's". Castanea 34: $394-397$ (1969).

Russell, G.E. and W.H. Duncan'. "An Annotated Checklist of Carex in Georgia". Castanea 37:200-214. 1972.

As title indicates--statewide list.

Semmes, D.R. Oil and Gas in Alabama. Geological Survey of Alabama, Special Report No. 15. 1929 (out of print).

Schultz V. "Status of Beaver and Otter in Tennessee". Jour. Tenn. Acad. Sci. 29:73-81. 1954a.

Statewide summary.

. "Status of the Bobcat in Tennessee". Jour. Tenn. Acad. Sci. $29: 66-72$. $19.54 \mathrm{~b}$.

Statewide summary.

- "Status of the Spotted Skunk, Common Skunk and Woodchuck in Tennessee". Jour. Tenn. Acad. Sci. 29:305-314. 1954 c.

Statewide summary.

. "Status of the Coyote and Related Forms in Tennessee". Jour. Tenn. Acad. Sci. 30:44-46. 1955. 
Statewide summary.

"Status of the Racoon in Tennessee". Jour. Tenn. Acad. Sci. 31:263-267. 1956a.

Statewide summary.

. "Status of Red and Gray Foxes in Tennessee". Jour. Tenn.

Acad. Sci. 31:268-274. 1956b.

Statewide summary.

. "Status of Mink and Muskrat in Tennessee". Jour. Tenn.

Acad. Sci. 34:89-96. 1959a.

S.tatewide summary.

. "Status of the Opossum in Tennessee". Jour. Tenn. Acad. Sci. 34:84-88. 1959b.

Statewide summary.

Segars, C.B., L.C. Crawford, and A.M. Harvill. "The Occurrence and Distribution of Hemlock in Alabama". Ecology 32:149-151. 1951.

Documents the occurrence of the northern species along rivers and in gorges in north Alabama.

Scott, A.F. and David H. Snyder. "The Amphibians and Reptibles of Montgomery County, Tennessee". Jour. Tenn. Acad. Sci. 43: 79-84. 1968.

Complete county list. Annotated.

Scott, M.A. "A Survey of Benthic Macroinvertebrates of Dale Holluw Reservoir, Tennessee, with Emphasis on the Effects of Coal Mine Drainage." M.S. Thesis. Tennessee Technological University. 1972 .

Lists of aquatic invertebrates. 
Shanks, R. E. "Trichomanes boschianum Sturm at Sewanee, Tennessee". Jour. Tenn. Acad. Sci. 22:146-148. 1947.

Discusses the history of the discovery and rediscovery of this very rare fern in Tennessee.

. "Checklist of the Woody Plants of Tennessee". Jour. Tenn. Acad. Sci. 27:27-50. 1952 .

Statewide distribution Iists--good county records.

. "Woody Plants of Tennessee: First Supplement". Jour.

Tenn. Acad. Sci. 28:158-159. 1953.

Expands coverage of the comprehensive 1952 work.

. "Woody Plants of Tennessee: Second Supplement". Jour.

Tenn. Acad. Sci. 29:234-237. 1954.

"Floristic Regions of Tennessee". Jour. Tenn. Acad. Sci. 33:195-210. 1958 .

Geographic distribution of plants on basis of physiographic areas.

Shanks, R.E. and K.J. Eharp. "Bummer Key to the Irees of tastern Tennessee". Jour. Tenm. Acad. Sci. 22:114-133. 1947.

Excellent summer key to the trees of the eastern half of state, including DeKalb County.

Sharp; A.J. "Taxonomic and Ecological Studies of Eastern Tennessee Bryophytes". Amer. Midl. Nat. 21:267-35. 1939.

Most comprehensive work on Tennessep hrynphytes in exictencc:

- "Preliminary Keys to the Genera and Species of Tenncssee Ferns". Jour. Tenn. Acad. Sci. 30:85-89. 1955.

These keys complement Shaver's book which was published without taxonomic keys. 
Sharp, A.J. and A. Baker. "First and Interesting Reports of Flowering Plants in Tennessee". Castanea 29: 1964.

Shaver, J.M. "Trillium sessile L. in Tennessee". Jour. Tenn. Acad. Sci. $34: 3 \overline{1-39 . ~} 1959$.

Discusses taxonomy of Trillium sessile and distribution in Tennessee.

Shaw, E.W., and K.F. Mather, The Oil Fields of Allen County, Kentucky, with Notes on the Geology of Adjoining Counties. U. S. Geological Survey. Bulletin 688. 1919.

Shendrikar, Arun D. and Gerald B. Faudel. "Distribution of Trace Metals during Oil Shale Retorting". Environmental Science and Technology. $12: 3$. 1978 .

Evidence is presented for low-level migration of fluorine, boron, copper, arsenic, and zinc to the water fraction and the shale oil product.

Silva, H. "Algae of the Tennessee Valley Region: A Manual for Identification". Ph.D. Dissertation. Michigan State University. 1951.

Sinclair, R.M. "Some noteworthy records of amphibians in Tennessee". Herpetologica 6:200-202. 1950a.

Extends ranges of some salamanders in Tennessee.

"Notes on some salamanders from Tennessee". Herpetologica 6:49-51. 1950b.

Small, J.K. Flora of the Southeastern United States. The Author, New York. 19:3. 1394 pp.

Synoptic flora. Best early general work for Southeast. Superseded by Small (1933).

$1554 \mathrm{pp}$ 
Excellent Synopsis of Southeastern Flora.

Smith, D.K. and K. D. McFarland. "The Discovery of Tortula fragilis Tay1. (Musci) in Tennessee". Jour. Tenn. Acad. Sci. 52: 75-76. 1977.

Reports the discovery of this moss taxa in Tennessee on Caney Fork River bluffs in Smith County very near DeKalb County.

South Central Tennessee Development District. Regional Land Use Plan 1977-2000. 1977 .

The land use plan attempts to determine where growth will occur in the region between 1977 and 2000 by examining population and economic trends and existing land use patterns and local land use plans. The suitability of the land to support growth is examined in terms of the soil slope limitations, the location of community facilities, and existing regulations. This information is used to determine where growth should be directed in the region. Goals and policies are established to assist in guiding regional growth. A discussion of how the region is expected to grow is presented. Land use policies and implementation measures are given which will assist in the implementation of the plan.

- Land Use Analysis and Water-Sewer Management Analysis. 1974.

The land use study is an analysis of the distribution of land uses in 13 South Central Tennessee counties. An examination of population and development trends is compared to the existing settlement pattern. Strategies for the implementation of a regional planning and developmenl program are recommended. The findings of the study are used to update the agency program design.

The water-sewer management analysis focuses on the extensive amount of existing water-sewer planning and the ongoing efforts. The results of this inventory of existing systems and planning programs are recommendations for a coordination policy and a management assistance program by the agency. 
Sternitzke, H.S. Tennessee's Timber Economy. U.S.D.A. For. Res. Report No. 9. 1955.

Swingle, H.S. "Fish Populations in Alabama Rivers and Impoundments". Trans. Am. Fish. Soc. 83:47-57. 1954.

Authoritative early list for Alabama.

Svenson, H. K. "Notes on the Tennessee Flora". Jour. Tenn. Acad. Sci. $16: 111-160.1941$.

Preliminary early list. Interesting but very incomplete.

Tennessee, State of. State Planning Division, State Planning Commission. Employment Growth Patterns in Tennessee. 1971.

This study analyzes the growth and distribution of non-agricultural employment among the state's development districts, planning regions, metropolitan and rural counties. Also, employment for all state regions is projected to 1975, and conclusions are drawn about the ramifications of changes in county and regional growth.

- Department of Employment Security, Research and Statistics Section. Tennessee Civilian Work Force Estimates by Area 1968-1972. 1972 .

Contains annual average work force information for all Tennessee counties. Included in this publication are 1968-1972 annual averages for all nonmetropolitan counties, as well as 1966-1972 averages for Tennessee and four Standard Metropolitan Statistical Areas (Chattanooga, Knoxville, Memphis and Nashville).

- State Land Use Planning Task Force. An Approach to Land Use Issues in Tennessee: A Report on the Findings and Recommendations of the Tennessee State Land Use Planning Task Force. 1973.

This report contains the findings and recommendations of the Tennessee State Land Use Planning Task Force, a body organized to advise the Tennessee General Assembly on legislation needed to initiate a sound stale land use planning program. The report contains analyses of local land use controls, land use programs of the states and 
pending federal land use legislation. This is followed by the specific findings of the Task Force on various land use problems and issues in Tennessee, along with recommendations for initiating a sound state land use planning and management program. $1974 a$.

- State Planning Office. Smithville, Tennessee Sketch Plan.

The Smithville Sketch Plan is the initial planning document for the city. This report contains an analysis of economic and population data, land use, transportation, and community facilities. Based on this analysis and population projections for 1990, a land use plan, transportation plan, community facilities plan, and recommendations for public improvements were prepared.

. State Planning Office. Tennessee Migration, Population, - Families, Income, and Manpower Demand Projections for Development Districts and Counties. $1974 \mathrm{~b}$.

This publication is a compilation of population and economic projections for 1980 and 1990 and is designed to provide a standard series of projections to be utilized by the various state departments and regional planning bodies. It presents migration and population by age and sex, families, incone, and manpower demand projections to 1990 for the state of Tennessee, development districts, and counties.

- State Planning Office, Upper Cumberland Section. Land Use Transportation Plan, Putnum County, Tennessee, Volume 1. 1974c.

Futurc commercial, residential, industrial, and recreational land uses are recommended and depicted on maps. These recommendations are based on the needs estimated by the trends that the population and economic data have established. This information is combined with and weighed against all other data collecled (natural features, present land use trends, and present road network). The final product is a compatible consideration of all future needs projected and properly located so that the future land needs of Putnam County 
are adequately provided for and arranged in the most efficient and least conflicting manner. Analyzes the present road, rail, and air transportation needs in Putnam County and provides recommendations for future modes improvements and developments, which will serve any probable increase in use of the transportation.

\section{$1975 \mathrm{a}$.}

State Planning Office. Alexandria Tennessee Sketch Plan.

The Alexandria Sketch Plan is the initial document for the city. This report contains an analysis of economic and population data, land use, transportation, and community facilities. Based on this analysis and population projections for 1990, a land use plan, transportation plan, community facilities plan, and recommendations for public improvements were prepared. $1975 b$.

- State Planning Office. Dowelltown, Tennessee Sketch Plan.

The Dowelltown Sketch Plan is the initial planning document for the town. This report contains an analysis of economy and population, land use, transportation, community facilities, and a summary of the use of the disaster grant fund. Based on this analysis and population projections for 1990, a land use plan, transportation plan, comnunity facilities plan, and recommendations for public improvements were prepared.

. Housing Development Agency. Housing Needs Analysis. 1976.

Identifies the incidence of inadequate housing. in Tennessee by county and regional units. The unmet housing needs for each county, development district area, and the state are projected for 1977 and 1982. It also indicates vacant units, seasonal homes, mobile homes, projected losses in the housing stock, distribution and shifts in new construction type as well as estimates to show the kind of housing that should be constructed in counties to meet their projecled housing necds. 
- Department of Public Health, Division of Water Quality Control. Water Quality Management Plan for the Upper Cumberland River Basin. 1976. $217 \mathrm{pp}$.

Develops a basin-wide water quality management program to attain and protect water quality at a level that will meet present and future needs of the people of the region. .Includes a physical description of the upper Cumberland River hydrologic basin and aa evaluation of social and economic conditions affecting water quality.

- Department of Employment Security, Research and Statistics Section. Tennessee Employment Outlook, Industries and Occupations SMSA's 1974-1985. 1977a.

This publication is a supplement to the Tennessee Employment Outlook, Statewide, 1974-1985 released by the Research and Statistics Section of the Tennessee Department of Employment Security in February, 1977. This supplement contains estimated employment for 1977, 1978 and projected employment for 1985, by industry and occupation for each of the six Standard Metropolitan Statistical Areas in Tennessee. Also included is the employment change between 1974 and 1985 for each industry and the annual average job openings for each occupation.

. Housing Development Agency. Report on the Need for Housing in Tennessee. $1977 \mathrm{~b}$.

The Report on the Need for Housing in Tennessee 1977 provides housing producers and researchers with an accurate assessment of housing conditions and need at state, regional, and county levels. It utilizes $1970 \mathrm{U}$. S. Census information to establish the number, type, and condition of housing units in Tennessee. It also analyzes housing production since 1970 and current housing conditions.

Finally, the report examines components of housing need, cumulative need, unmet need, and special housing needs for immediate (1978), intermediate (1980), and long-range (1983). time periods.

. State Planning Office, Towns of Algood, Baxter and Ionterey and Putnum County Housing Study. 1977c. 
This study examines existing housing conditions in the Towns of Algood, Baxter, Monterey, and Putnam County, Tennessee. Current and future housing needs are determined and recommendations are made for meeting those needs. Special emphasis is given to the needs of low and moderate income persons.

. Wildlife Resources Agency. Tennessee Conservationist.

Numerous semi-popular articles on natural history and conservation. Now in its 49 th year.

State of Tennessee, State Planning Office and University of Tennessee, Knoxville, Center for Business and Economic Research. Tennessee Population and Housing 1950-1970. 1972.

This publication is a compilation of summary data from three consecutive censuses $(1950,1960,1970)$ designed to provide a profile of changes in population and housing characteristics in Tennessee counties over the last two decades, arranged for optimum comparability. Includes data on change and rank of county population and selection population and housing indicators by county.

- An Economic Report to the Governor of the State of Tennessee on the State's Economic Outlook. 1977.

This report reviews the national and state economic performance as measured by major economic factors and state revenues by source and by fund for the years 1975 to 1977. It forecasts levels of state economic activity based on national policy decisions for calendar years 1977 through 1985 and projects state revenues for the fiscal years 1978 to 1985 .

Top of Alabama Regional Council of Governments. Population and Economy of the TARCOG Report Number 1 -- An Overview. 1972a.

A review of the population and economic trends in the five-county Top of Alabama region is presented in this report. An analysis of the demographic trends shows that the region between 1950 and 1970 
experienced the most rapid growth rate of any area in the state. The economic analysis reveals a shift from an agriculturally-based economy in 1950 to a manufacturing, research and development and service economy in 1970 . The most rapid growth in the major urban county, Madison, occurred before 1966. In contrast, the greatest economic changes in two of the rural counties, Marshall and Jackson, occurred after that time. The major economic and demographic problems cited in the study include a weak industry mix dominated by low-skilled industries or those-with a declining market, such as aerospace and defense, migration, and transportation.

- Population and Economy of the TARCOG Region, Report Number 2 - The Region in the $1970^{\prime} \mathrm{s}$ and $1980^{\prime} \mathrm{s} .1972 \mathrm{~b}$.

This is the final report in a regional population and economic study of five counties in northeast Alabama. The report presents projections to 1980 and 1990 (and limited data to 2000) of the population by age group and race for each of the five counties. Total population projections are also offered for urban places. Updated projections of employment in the agricultural manufacturing and services sectors are presented for each county. A series of recommendations concerning balanced growth and development are also Included in this report:

- Top of Alabama Regional Land Use Survey and Analysis.

1973

This report delineates the characteristics of present land use development in the TARCOG Region, and provides insight into the prime developmental determinants affecting the existing land development pattern exhibited in the TARCOG Region. In addition to a regional overvicw, thic repurt depirts the major land use and development characteristics of the TARCOG Region on a county-bycounty basis.

- Top of Alabama Regional Community Facilities Plan. 1975. 
This study represents a planned approach to organizing needed improvements to the Region's community facilities and services for a planning period of 1975-2000. Community facilities are analyzed as facilities service systems rather than as local physical facilities due to the regional nature of this Plan. Recommendations regarding management and services coordination are emphasized as well as policies for future service system development. This Plan, in addition, proposes recommendations for future detailed programs needed to further enhance the quality of the Region's community facilities and services.

- Top of Alabama Regional Housing Plan. 1977a.

This study presents adopted goals, objectives, and policies relative to the provision of an adequate housing stock within the five-county TARCOG region. In addition, it includes an overview of housing in the region focusing on condition and demand as well as a discussion of major housing constraints and available public and private housing assistance measures.

- Top of Alabama Regional Land Use Plan. $1977 \mathrm{~b}$.

The Regional Land Use Plan provides a policy framework for future land use decision making. The plan proposes a strategy of environmental protection with sufficient latitude allowing the region's local governments to develop land use plans and policies tailored to their particular needs. The Plan identifies areas proposed for urban development, major industrial areas, commercial concentrations, agriculture, floodprone areas, public use management areas, and forestry. Transportation modes are identified with recommended improvements and policies.

Turner, D.B. Workbook of Atmospheric Dispersion Estimates. U. S. Environmental Protection Agency, Office of Air Programs. 1970. 
Turner, B.H. and E. Quarterman. "Ecology of Dodecatheon meadia I.. in Tennessee Glades and Woodland". Ecol. 49:909-9 $\overline{15 .} \overline{1968 .}$

Underwood, J.K. "The Genus Carex in Tennessee". Amer. Midl. Natr. $33: 613-643.1945$.

Excellent and comprehensive work on a difficult genus. Statewide.

U.S. Army Corps of Engineers, Nashville District. "Center Hill Lake". Pamphlet, undated.

- Nashville District. Water Quality Conditions in Center

Hill Lake. 1976.

- Army Corps of Engineers, Nashville District. Draft Environmental Assessment Report. 1977.

Environmental Assessment Report for the operation and maintenance of Center Hill Lake, Carrey Fork River, Tennessee.

U.S. Department of Commerce, Environmental Science Services Administration. Climatography of the U.S. No. 60-9, Climates of the States Georgia,. Revised 1969.

An updated version of the 1959 climatic summary by Horace S. Carter, State Climatologise. Concains freeze data, temperature and precipitation normals and normals, means and extremes for selected areas in Georgia.

- National Oceanic and Atmospheric Administration, Environmental Data Service. Climatography of the United States No. 60, Climate of Alabama. 1976.

This publication contains a narrative description of some of the main climatic features of the state based on representative stations in Alabama. It represents a modified format of earlier climatographies intended for general public use.

- Tennessee Valley Authority, Bureau of Economic Analysis. Projections - Economic Activity in Tennessee, Series E Pop 11 ation. 1976. 
The projections in this report incorporate the Census Bureau's 1972 "Series E" national population projection and the Bureau of Economic Analysis' industrial and regional disaggregation thereof, as published in The 1972-E OBERS Projections, November, 1974.

- National Oceanic and Atmospheric Administration. Seasonal and Annual Wind Distribution by Pasquill Stability Classes STAR Program. 1/49-12/53, 非93803. 1978.

Contains especially prepared monthly seasonal and annual summaries of winds structured by Pasquill stability classes based on five years of Smithville Weather observations.

U.S. Department of Energy, Clinch River Breeder Reactor Plant Project Office (CCRBRP). CRBRP Environmental Report, Section 2.6 "Meteorology".

These sections of the environmental impact report show comparisons of CRBRP on-site measurements longers record Oak Ridge data, summaries of CRBRP and Oak Ridge climatic records and stmospheric dispersion estimate $(X / Q)$ values from Gaussian straight line airflow dispersion models.

U.S. Environmental Protection Agency. Atmospherice Pollution Potential from fossil fuel resource extraction, on-site Processing and Transportation, by Radian Corporation. 1976.

U.S. Geological Survey. "Ground Water Resources of the Cumberland Plateau" 1958 .

- Surface Water Supply of the United States, 1966-70 Part 3:

Vol. 4. "Ohio River Basin Below Wabash River". 806 pp. 1973.

One of a series of 37 reports presenting records of stage and discharge of streams, and stage and contents of lakes and reservoirs in the United States during 1966-1970 water years. Contains the records for gaging stations and partial-record stations in the Ohio River basin below Wabash River. 
. Water Resources Division. "Water Resources Investigations in Kentucky, 1976." In cooperation with the Commonwealth of Kentucky, Kentucky Geological Survey, University of Kentucky and others. 1976.

Lists selected references on water resources in Kentucky, including USGS publications, professional papers and others.

. Water Resources Data for Kentucky, Water Year 1976. Water-Data Report KY-76-1. Prepared in Cooperation with the Commonwealth of Kentucky, University of Kentucky, Kentucky Geological Survey, and with other Federal Agencies.

"Flood Prone Area Maps" corresponding to the following 7-1/2 minute quadranglels: Petroleum; Scottsville. Prepared in Cooperation with the Commonwealth of Kentucky, Kentucky Geological Survey, University of Kentucky.

U.S. Weather Bureau. "Climatogtrapy of the United States No. 11-1, Climatic Summary of the United States." Supplement for 1931-1952.

Total precipitation, mean snowfall, temperature means, extremes and station index and history for cooperative climatic stations in Alabama .

- "Climatography of the U.S. Nn. 1]-7, Climatic Summary of the United States." Supplement for 1931-1952.

Total precipitation, mean snowfall, temperature means, extremes and station index and history for cooperative climatic stations in Georgia.

- "Climatography of the United States No. 11-13, Climatic Summary of the United States". Supplement from 1931-1952.

Total precipitation, mean snowfall temperature means, extremes and station index and history for cooperative climatic stations in Kentucky.

- "Climatography of the U.S. No. 11-35, Climatic Summary of the United States." Supplement for 1931-1952. 
Total precipitation, mean snowfall, temperature means, extremes and station index and history for cooperative climatic stations in Tennessee.

- "Climatography of the United States No. 60-1, Climates of the States - Alabama," 1959.

Narrative climatic summary of Alabama Climatic features by Arthur R. Long, State Climatologist. Contains tables of freeze data, temperature and precipitation means and normals, means and extremes for selected stations.

. "Climatography of the United States No. 60-15, Climates of the States - Kentucky," 1959.

Narrative climatic summary of Kentucky climatic features by $0 . K$. Anderson, State Climatologist. Contains tables of freeze data, temperature and precipitation means, and normals, means and extremes for selected stations.

- "Climatography of the United States No. 60-40, Climates of the States - Tennessee," 1960.

Narrative climatic summary of Tennessee climatic features by Robert R. Dickson, State Climatologist. Contains tables of freeze data, temperature and precipitation means, and normals, means and extremes for selected stations.

Upper Cumberland Development District. Population and Economic Base Study. 1973.

This study presents a comprehensive analysis of the population and economic base of the UCDD. In the study analysis of income and earnings, sources of employment, the general nature of the population, and likely future trends are examin from standard of their current status. 

1976 .

- Regional Transportation Inventory and Analysis, Phase 1.

This report describes the UCDD population and economy and physical resources. It presents District Transportation goals and policies. It includes an inventory of District Transportation facilities, including highway, air, water rail, bus, trucking, and mass transmit facilities .

- Future Land Use Plan 1955. 1977.

A future land use plan for the Upper Cumberland Development District is presented. Demographic and economic analysis of the region are included. Also included are regional land development policies and objectives to guide growth in the area. Individual future land use plans are presented for each of the fourteen counties, but these plans are coordinated to result in a regional development plan. A discussion of implementation methods is included.

Webb, George W. "The Hardwood Lumber Industry of the Eastern Highland Rim. Jour. Tenn. Acad. Sci. 32:16-227. 1957.

Wells, J.R. and A.J. Sharp. "The Coffeoidae (Rubiaceae) of Tennessee." Jour. Tenn. Acad. Sci. 141:14/-133. 196́6́.

Wilson, C.B. and H.W. Clark. The Mussels of the Cumberland River and its Tributaries. U.S. Bureau of Fisheries. Doc. No. 781. 1914. 63 pp.

Wofford, B.E., D.H. Webb, and W.M. Dennis. "State Records and Other Recent Noteworthy Collections of Tennessee Plants II." Castanea 42:190-193. 1977.

Wood, George H. and Alfred M.F. Johnson. Flow Characteristics of Tennessee Streams. "Part A. Summaries of Flow Duration and Low and High Flows at Gaging Stations." Prepared cooperatively by the U.S. Geological Survey, Water Resources Division and the Tennessee Department of Conservation, Division of Water Resources. 1965. $226 \mathrm{pp}$. 
First of a series of reports for Tennessee dealing with analyses of stream flow characteristics that are useful for planning, designing, and operating water projects of all types. The data presented in this report show: (1) the magnitude and duration of daily discharge (flow-duration); (2) the magnitude of the lowest mean dischange, in cubic feet per second, for selected periods of consecutive days;

(3) the magnitude of the highest mean discharge, in cubic feet per second, for selected periods of consecutive days.

Wooden, J. and D. Caplenor. "A Comparative Vegetational Study of Two North-facing Slopes at Rock Island State Park, Rock Island, Tennessee." Jour. Tenn. Acad. Sci. 47:146-151. 1972.

Best description in literature on a community similar to Caney Fork Gorge in DeKalb County. 